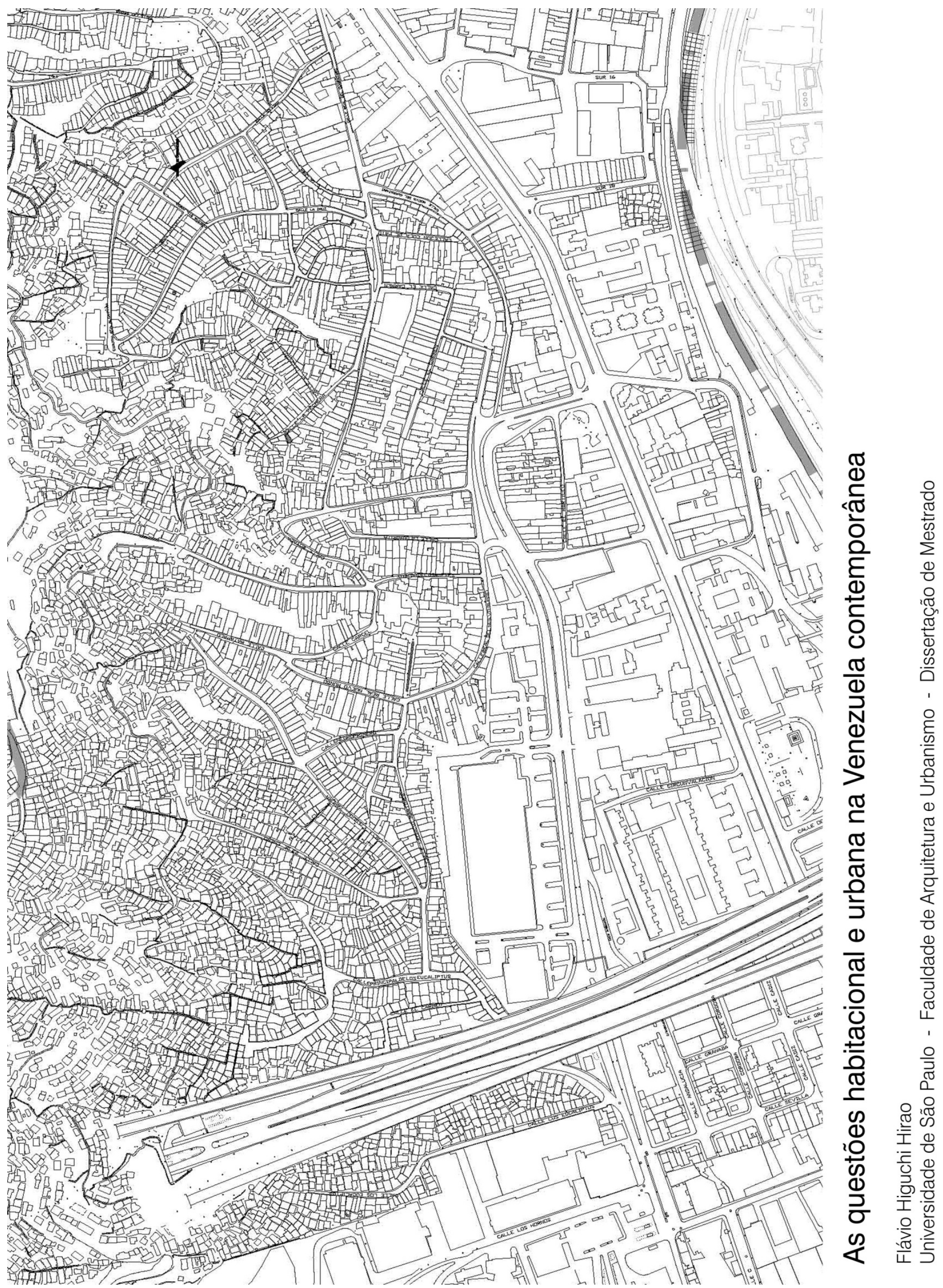


Flávio Higuchi Hirao

\title{
As Questões Habitacional e Urbana na Venezuela Contemporânea
}

\author{
Dissertação apresentada à \\ Faculdade de Arquitetura e Urbanismo da \\ Universidade de São Paulo para \\ obtenção do título de Mestre.
}

Área de Concentração: Habitat

Orientadora: Prfa. Dra. Maria Lúcia Refinetti Rodrigues Martins

São Paulo, fevereiro de 2015 
AUTORIZO A REPRODUÇÃO E DIVULGAÇÃO TOTAL OU PARCIAL DESTE TRABALHO, POR QUALQUER MEIO CONVENCIONAL OU ELETRÔNICO, PARA FINS DE ESTUDO E PESQUISA, DESDE QUE CITADA A FONTE.

E-MAIL DO AUTOR: flavio.higuchi@gmail.com

Hirao, Flávio Higuchi

H668q As questões habitacional e urbana na Venezuela

contemporânea / Flávio Higuchi Hirao. --São Paulo, 2015. 172 p. : il.

Dissertação (Mestrado - Área de Concentração: Habitat) FAUUSP.

Orientadora: Maria Lucia Refinetti Rodrigues Martins

1.Movimento social urbano - Venezuela 2. Habitação popular Venezuela 3.Urbanização - Venezuela 4.Favelas - Venezuela

5.Planejamento territorial urbano - Venezuela I.Título

CDU 304:36:711.58(87)

Esta pesquisa contou com apoio da bolsa de mestrado da Capes. 



\title{
Resumo
}

Essa dissertação aborda a questão urbana e habitacional na Venezuela. Realiza-se investigação histórica sobre os principais períodos da política habitacional na Venezuela a partir de 1928 (fundação do Banco Obrero), seguida pela caracterização do programa Gran Misión Vivienda Venezuela (sob a gestão de Hugo Chávez) e dos movimentos sociais urbanos reunido em torno da plataforma do Movimiento de Pobladoras y Pobladores. Investiga-se a importância da formação das favelas e a subsequente luta pelo reconhecimento como acontecimentos fundamentais para o processo político contemporâneo na Venezuela.

\begin{abstract}
This dissertation studies the urban and housing issues in Venezuela. It takes a close look at historical research during the main time periods of housing policy in Venezuela from 1928 (formation of Banco Obrero), followed by the characterization of the program "Gran Misión Vivienda Venezuela" (under the administration of Hugo Chávez), and the urban social movements surrounding the platform of "Movimiento de Pobladoras e Pobladores." It researches the importance of the development of the slums and the subsequent struggle for their recognition as key events in understanding the current political process in Venezuela.
\end{abstract}

\section{Resumen}

Esta tesis aborda la cuestión urbana y habitacional en Venezuela. Empezando con la investigación histórica sobre los períodos clave de la política de vivienda en Venezuela a partir de 1928 (fundación del Banco Obrero), se hace la caracterización del programa habitacional Gran Misión Vivienda Venezuela (bajo la gestión de Hugo Chávez) y de los movimientos sociales urbanos reunidos alrededor del Movimiento de Pobladoras y Pobladores. Investiga la importancia de la formación de los barrios y la posterior lucha por el reconocimiento como eventos clave para la comprensión del proceso político contemporáneo en Venezuela.

\begin{tabular}{|c|c|c|c|c|}
\hline \multicolumn{5}{|c|}{ 5.Planejamento territorial urbano } \\
\hline Keywords: & $\begin{array}{l}\text { 1. Urban Social Movement; } \\
\text { 5. Urban Planning }\end{array}$ & 2. Social Housing; & 3. Urbanization; & 4. Slums; \\
\hline Palabras Clave. & 1. Movimiento Social Urbano; & 2. Vivienda Social; & 3. Urbanización; & 4. Barrios; \\
\hline
\end{tabular}

5. Planificación Territorial Urbana. 


\section{Índice}

$\begin{array}{ll}\text { Apresentação } & 3\end{array}$

$\begin{array}{ll}\text { Introdução } & 5\end{array}$

PARTE 1 - CONTEXTUALIZAÇÃO

Capítulo 1. Introdução à estrutura urbana da Venezuela 13

Capítulo 2. O Petro-Estado e a Cidade: Breve história de uma relação 36

PARTE 2 - A QUESTÃO HABITACIONAL E URBANA NA VENEZUELA CONTEMPORÂNEA

Capítulo 3. Cidade e Habitação pós 1999

Capítulo 4. O Movimiento de Pobladoras y Pobladores 113

$\begin{array}{ll}\text { Capítulo 5. Uma história: La Vega e Kaika-Shi } & 147\end{array}$

$\begin{array}{ll}\text { Reflexões Finais } & 161\end{array}$

$\begin{array}{ll}\text { Bilbiografia } & 164\end{array}$ 


\section{Apresentação}

Ao chegar de madrugada pela primeira vez em Caracas, em março de 2011, não haviam vagas nos hotéis da cidade. Um dos motivos que levavam à lotação eram os desabrigados pelas chuvas, levados aos hotéis pelo governo. No dia seguinte, participei de atividade do Movimiento de Pobladoras y Pobladores, que discutiam crédito coletivo, propriedade coletiva, e socialismo. Enquanto isso, no Brasil, assistíamos aos primeiros efeitos do Minha Casa Minha Vida.

Voltei a Caracas em julho de 2011, na ocasião do XII Encuentro Latinoamericano de Vivienda Popular (Selvip). Movimentos de toda a América Latina se reuniram em Caracas, e seriam recebidos por Hugo Chávez. A internação em Cuba inviabilizou a recepção.

Entre julho de 2012 e setembro de 2013 vivi em Caracas trabalhando como bolsista da missão do Instituto de Pesquisa Econômica Aplicada (IPEA) na Venezuela, ocasião em que pude também atuar junto ao movimento social. A experiência pelo IPEA possibilitou que eu conhecesse o processo político por dentro as instituições - trabalhávamos dentro da PDVSA e do Ministerio de Ciência e Tecnologia.

A última viagem ao país foi em dezembro de 2014, na ocasião do 4o. ELAC - Encuentro Latinoamericano de Arquitectura Comunitária.

Desde a primeira até a última viagem muita coisa aconteceu na Venezuela. Presenciamos a vibrante reeleição de Hugo Chávez em 2012, e seu falecimento em março de 2013. Também presenciamos as eleições turbulentas de Nicolás Maduro em abril de 2013, que já indicavam um futuro preocupante para a Venezuela como um todo.

Quando fui morar na Venezuela, o dólar paralelo estava cotado em 9 bolívares. Neste momento, início de 2015, está cotado em 200 bolívares. O preço do barril de petróleo em 2011 chegou a 111 dólares. Desde o final de 2014 o preço decresce radicalmente, chegando a valores inferiores a 50 dólares. Os efeitos de tal queda ainda estão para serem sentidos na sociedade venezuelana, uma vez que o barril vendido a preços abaixo de 50 dólares hoje serão pagos dentro de alguns meses. Cada dia que passa novas notícias preocupantes chegam da Venezuela.

Este dissertação vem se somar ao mestrado de José Baravelli, "O cooperativismo uruguaio na habitação social de São Paulo. Das cooperativas FUCVAM à Associação de Moradia Unidos de Vila Nova Cachoeirinha" que aborda a habitação por autogestão no Uruguai e sua influência no Brasil, assim como ao mestrado de Kaya Lazarini, "Luta por Habitação e Autogestão em Buenos Aires: da crise à construção popular do habitat". Esperamos que seja mais uma contribuição na formação de um pensamento brasileiro latinoamericano a respeito da habitação, da autogestão e da luta urbana por uma cidade mais justa.

São Paulo, fevereiro de 2015. 
A meu pai Roberto

(in memoriam)

E aos sobrinhos que chegaram 


\section{Introdução}


A realização de uma pesquisa sobre outro país apresenta algumas particularidades. Em primeiro lugar, há a interessante posição de nosso olhar estrangeiro, que impõe naturalmente uma perspectiva comparativa, contribuindo para problematizarmos não apenas a realidade de lá, mas também a realidade de cá. Por outro lado, ao estudar um objeto estrangeiro não contamos, em um primeiro momento, com pressupostos básicos de conhecimentos históricos - cujo domínio quando em nosso próprio território se coloca como condição primeira para início do estudo.

Por esse motivo essa dissertação está dividida em duas partes, sendo a primeira dedicada à contextualização e a segunda à questão habitacional e urbana na Venezuela contemporânea. Mas cabe explicar que a contextualização, se aqui está no início da dissertação, foi na realidade elaborada a posteriori: ela surgiu a partir da observação (estranhada e curiosa do estrangeiro) da realidade atual das cidades venezuelanas. Esta observação foi realizada na imersão dentro daquela sociedade, onde morei por cerca de 1 ano e meio, trabalhando dentro de instituições do governo (como bolsista em convênio de cooperação internacional), participando de atividades junto ao movimento social (como arquiteto militante) e dos momentos políticos históricos e, afinal, vivendo e sofrendo com a complexidade do processo político atual. Também é importante destacar que não foi realizado um trabalho etnográfico, que demandaria esforços metodológicos que não foram feitos. De qualquer forma, o estranhamento permaneceu como o guia condutor da pesquisa histórica que abre essa dissertação. A partir do estranhamento buscaram-se os fios históricos explicativos.

Evitamos realizar uma abordagem unilateral a partir das ações do Estado. O projeto de pesquisa que deu origem à presente dissertação questionava em seu título: "Outro Estado, Outra Cidade?". No meio do percurso, percebemos que, afinal, poderíamos estar diante do inverso: outra cidade, outro Estado? De fato, ao puxar os fios históricos, começamos a perceber que a questão urbana permeia toda a história por trás do atual modelo de Estado. Se tratam de revoltas urbanas, reivindicações por serviços públicos, contra o aumento do preço do ônibus, das favelas e suas luta pelo reconhecimento, em cujos processos se nega o Estado neo-liberal e se reivindica a formação de um governo de base popular.

Os estranhamentos? Ao andar pela capital da Venezuela percebe-se uma espécie de Caracas Delirante. É a sobreposição e confrontação de estruturas espaciais chocantes entre si, como a favela de San Augustín em frente ao chamado Parque Central - uma megaestrutura formada por 8 edifícios habitacionais de 44 pavimentos (o Copan em São Paulo conta com 35), que 
circundam 2 torres de 59 pavimentos e 225 metros de altura (consideradas as mais altas da América Latina até 2003). Choque maior ocorre quando descobrimos que o promotor de toda essa mega-estrutura construída foi o próprio Estado, por meio do Centro Simón Bolívar. À frente do Parque Central se avista o Teatro Teresa Careño, segundo os caraquenhos, o maior da América Latina com 80 mil metros quadrados de construção, também obra do Centro Simón Bolívar. À frente, o atual hotel Alba, antigo Hotel Hilton, desapropriado na gestão de Hugo Chávez - e também erguido pela mesma instituição estatal. Todos construídos no período da Venezuela Saudita da década de 1970. Sem dúvida, o petróleo está por trás da criação de uma cidade de extremos .

Esses exemplos foram colocados apenas para introduzir a idéia levantada por Fernando Coronil, de que a Venezuela historicamente criou uma espécie de Estado Mágico. Coronil parte do seguinte trecho de José Ignácio Cabrujas:

"La aparición del petróleo como industria creó en Venezuela una especie de cosmogonía. El Estado adquirió rápidamente un matriz 'providencial'. Pasó de un desarrollo lento, tan lento como todo lo que tiene que ver con la agricultura, a un desarroollo 'milagroso' y espetacular. [...] Un candidato que no nos prometa el paraíso es suicida. Porque? Porque el Estado no tiene nada que ver con nuestra realidad. Es Estado es un brujo magnánimo. [...] El petróleo es fantástico y por lo tanto induce a lo 'fantasioso'. El anuncio de que éramos un país petrolero creó en Venezuela la ilusión de un milagro. Creó en la práctica la 'cultura del milagro'." (Coronil, 2013: 37)

O fantástico costuma ser o "maior da América Latina", ou o mais moderno - o modernismo arquitetônico incluído. Para Cabrujas, a Venezuela crescia economicamente "casi como los ciclos de la naturaleza". Pois o país pouco dependia dos esforços produtivos internos, crescendo economicamente a partir de variações externas à sua economia, como os ciclos da natureza - leia-se, os ciclos dos preços internacionais do petróleo. Para um olhar estrangeiro, as obras de magia, as tiradas da cartola do Estado Mágico, são impressionantes. Celso Furtado percebia com olhar crítico:

"Eu tinha diante dos olhos, pela primeira vez, fenômeno dessas economias que crescem apoiadas em um setor de altíssima produtividade que utilizava um recurso não renovável. Por mais que se enriqueçam, não adquirem autonomia 
de crescimento e podem desmoronar como um castelo de cartas. Todos os segmentos da sociedade recebiam de alguma maneira um tipo qualquer de subsídio, o que produzia um consenso que legitimava a irracionalidade econômica". (Furtado, 2008: 160)

A construção civil, nesse contexto, amplia sua função na economia e na política do país. As grandes obras de infra-estrutura, equipamentos públicos e habitação se tornam objetos fantásticos de um suposto progresso, ao mesmo tempo em que dão vazão a parcela importante da renda do petróleo e mobilizam quantidade significativa da mão-de-obra urbana em uma sociedade de baixa industrialização. Nessa dissertação iremos centrar nossa análise na parte habitacional, e não abordaremos as obras de infra-estrutura, que apresentam características específicas relativas às empresas construtoras, impacto no território, canteiro de obras, tecnologia e composição orgânica do capital.

Celso Furtado foi a Caracas pela primeira vez em 1957 com o objetivo de preparar um estudo sobre a economia venezuelana para a Comissão Econômica para a América Latina (Cepal). Para Raúl Prebisch, o estudo deveria "(...) ter por base a análise dos problemas da Venezuela, que costumam ser, em alguns aspectos, muito diferentes dos que existem no resto da América Latina" ${ }^{1}$. O petróleo é certamente o principal motivo que faz a economia da Venezuela tão diferente dos outros país latinoamericanos. A frase que iniciava os escritos de Furtado em 1957 era direta: "A venezuela é a economia subdesenvolvida de mais alto nível de produto per capta que existe atualmente no mundo". O país apresentava renda per capta semelhante à Alemanha Ocidental e superior em mais que o o dobro da América Latina.

Furtado voltou ao país em 1974, então convidado pelo ministério de planejamento da Venezuela. Naquele momento, a economia mundial entrava na fase marcada pelo boom petroleiro a partir dos acordos internos da Organização dos Países Exportadores de Petróleo (OPEP). Naquela ocasião vislumbrava possibilidades enormes para o país:

"Poucas vezes um desafio tão sem ambiguidades se apresentou a um grupo de dirigentes, ampliando abruptamente o campo do possível, numa confirmação de que na história dos povos as mudanças qualitativas se realizam por muitos caminhos. Nos próximos dois decênios a Venezuela poderá ter saltado a barreira que separa subdesenvolvimento de desenvolvimento, sendo quiçá o

\footnotetext{
${ }^{1}$ Carta de R. Prebisch a Silvio Gutiérres, 2 de julho de 1956. (Furtado: 9)
} 
primeiro país da América Latina a realizar essa façanha, ou terá perdido sua chance histórica". (Furtado, 2008: 125)

Em 1978 Furtado voltou ao país para um seminário acadêmico. Haviam passado quatro anos de entrada massiva de recursos durante o perído que ficou conhecido como "Venezuela Saudita".

"Quatro anos chovendo ouro em cima deste país! Uma experiência histórica que merece ser seriamente estudada. As estruturas sociais se deslocaram. Digamos que todos os grupos sociais hajam recebido algum benefício: os subsídios ao consumo atingiram o conjunto da população. Mas os subsídios absorvidos pelos grupos de renda média e alta cresceu todo o tempo. [...] As transformações que haviam ocorrido eram consideráveis. A chuva de dinheiro tivera o efeiro de uma verdadeira enxurrada. Dizia-se corretamente que o país havia tomado um porre e precisava de algum tempo para recuperar o equilíbrio". (Furtado, 2008: 24)

Naquela ocasião, "a única coisa certa era que a oportunidade de saltar por cima do subdesenvolvimento se perdera". Em 1976, em pleno boom petroleiro, Juan Pablo Pérez Alfonso, considerado por muitos como o fundador da OPEP, publica livro denominado "Afundando-nos no excremento do diabo". O petróleo passa a ser percebido, de uma grande benção, a um grande maldição. E para Furtado, "nada mais perigoso para um país pobre do que uma chuva de dinheiro".

De fato, passada a chuva de dinheiro da década de 1970, não demorou muito para a economia cair como um castelo de cartas. O dia 18 de fevereiro de 1983 ficou marcado na história da Venezuela como o "Viernes Negro", um conjunto de medidas macroeconômicas tomadas pelo presidente Luís Herrera Campíns (1979-1984), que incluía a desvalorização da moeda nacional, o bolívar, e a redução dos investimentos sociais, e teve impacto profundo e imediato no conjunto da sociedade venezuelana. Para curar os males do "rentismo petroleiro", a Venezuela deveria, afinal, entrar na linha dos outros países do continente, ou seja, aderir ao "Consenso de Washington". Talvez o Caracazo, a enorme revolta social urbana que tomou todas as cidades do país em 1989, tenha sido a primeira grande revolta do continente contra as receitas neoliberais. 
O Caracazo abriu a década de 1990 na Venezuela, seguido por duas tentativas de tomada do poder liderada por Hugo Chávez no ano de 1992. A crise econômica se juntava à crise institucional de um pacto de governabilidade no qual apenas 2 partidos haviam governado o país desde o ano de 1959. Com revoltas, protestos e tentativas de golpe, a política na década de 90 estava em aberto. Em 1998 Chávez venceu as eleições presidenciais e assumiu no ano de 1999, jurando sobre o que denominou como uma "moribunda constituição"; já em 1999 chamou uma assembléia constituinte, em um processo cujo tom era a refundação o Estado se entrava na chamada Quinta República.

As gestões chavistas foram lastreadas por altas seguidas dos preços internacionais do petróleo. Mas, ao contrário de tantas gestões anteriores, os petro-dólares não se materializaram em obras megalomaníacas, mas sobretudo em investimentos pesados em todas as áreas sociais. As chamadas misiones entraram massivamente nos territórios pobres do país, como a Missión Barrio Adentro, que conta com a construção de módulos de saúde dentro dos territórios das favelas e comunidades pobres por todo o território da Venezuela, onde médicos cubanos realizam atendimento e fazem planos de prevenção, ou a Misión Róbinson, de educação, cujos resultados foram reconhecidos pela Unesco ao declarar a Venezuela país livre do analfabetismo.

Quanto à habitação, várias foram as missões lançadas pelo governo, mas todas com tímidos resultados até o ano de 2011, quando foi lançado programa Gran Misión Vivienda Venezuela.

O Gran Misión Vivienda Venezuela tem apresentado resultados importantes, ao intervir na cadeia construtiva habitacional, o que inclui os terrenos, materiais de construção e executores. Ao mesmo tempo, o movimento social urbano, articulado em torno do Movimiento de Pobladoras y Pobladores, apresenta uma alternativa de base popular que merece atenção.

A recente queda abrupta dos preços internacionais do petróleo, entre 2014 e 2015, abre novamente o futuro da política na Venezuela. Hoje, os avanços, limites e contradições da gestão chavista desde 1999 estão colocados à prova. A ecomomia venezuelana está entrando rapidamente em colapso. A grande preocupação é lembrar da análise de Furtado de que "quanto mais alto o nível de vida das gerações presentes, maiores problemas deverão enfrentar as futuras quando começar a esgotar-se o tesouro que receberam". 
No Capítulo 1, realizamos uma breve contextualização da estrutura urbana da Venezuela formada durante os períodos agro-exportador e petro-exportador, marcada pela concentração urbana em poucos núcleos importantes e pela formação das grandes metrópoles atuais.

No Capítulo 2, ainda como contextualização, abordamos brevemente a relação entre o Estado petroleiro rentista e a questão habitacional e urbana. A investigação histórica descortina uma série de políticas habitacionais que atenderam a diversos objetivos, muitos deles em nada vinculados à habitação em si. Iniciamos nossa análise com a formação do Banco Obrero no ano de 1928, momento de consolidação do Estado petroleiro durante a ditadura do General Juan Vicente Gómez. Outra ditadura, a do General Marco Pérez Jimenez na década de 1950, tem na questão habitacional uma de suas marcas fantásticas, com a construção dos superblocos modernistas em uma das maiores experiências habitacionais do mundo na época. A democracia conquistada em 1959 irá consolidar um sistema de poder pactuado entre dois grandes partidos que acabariam por repartir o poder durante 40 anos. Nesse período, conhecido como Pacto de Punto Fijo, verificamos a oscilação de uma política habitacional com maior ou menor grau de intervenção do Estado. A crise econômica da década de 1980 irá reduzir drasticamente os investimentos em todas as áreas sociais, incluindo a habitação. A revolta urbana que se segue e a luta pelo reconhecimento das favelas são abordadas como elementos fundamentais para a compreensão do período que se abre com a eleição de Hugo Chávez em 1998.

A Parte II da dissertação aborda a questão habitacional e urbana na Venezuela contemporânea. No Capítulo 3 investigamos como a luta pelo reconhecimento das favelas se desenvolveu após a eleição de Chávez, momento em que os Comités de Tierras Urbanas (CTU) emergiram como importantes agentes políticos. Ainda no Capítulo 3, realizamos caracterização do programa Gran Misión Vivienda Venezuela, caracterizada por uma forte atuação do Estado na cadeia produtiva da habitação.

No Capítulo 4 abordamos o Movimiento de Pobladoras y Pobladores, cuja origem se vincula diretamente aos movimentos das favelas, com atenção maior nos chamados Campamentos de Pioneros - Nuevas Comunidades Socialistas, que se propõem a "resgatar" terras urbanas ociosas e realizar a construção de moradias por sistema de autogestão. 
O capítulo 5 narra brevemente a história da favela de La Vega e do Campamentos de Pioneros Kaika-Shi, nos quais encontramos a confluência de diversos acontecimentos vinculados à questão urbana e habitacional contemporânea na Venezuela. 
Introdução à estrutura urbana da Venezuela 
Com 88,8\% de sua população residente em cidades segundo o Censo de Población y Vivienda 2011, a Venezuela apresenta atualmente o quarto maior índice de urbanização entre os países sulamericanos, atrás de Uruguai (95,2\%), Argentina (91,6\%), e Chile (89,4\%). O Brasil, segundo o Censo Demográfico de 2010, conta atualmente com 85,4\% de sua população residente em cidades, o que o posiciona na quinta colocação.

No ano de 1940, Uruguai, Argentina e Chile já contavam com a maioria de suas populações vivendo em cidades, enquanto Brasil e Venezuela contavam com 26,4\% e 33,5\% respectivamente. No ano de 1970, enquanto a população urbana brasiliera passava a 55,9\%, a Venezuela já contava com 75\%, proporção que a aproximava do Uruguai (82\%), Argentina (78,5\%) e Chile $(75,1 \%)$. Tais números demonstram que, se a urbanização acelerada foi realidade em praticamente todos os países da América Latina, foi ainda mais veloz na Venezuela, no que provavelmente se configura como o mais acelerado processo de urbanização do continente.

Segundo Silverio Gonzalez (2005: 95), "los caraqueños nacidos en 1941 descubrieron una ciudad siete veces más populosa en 1971, que se había formado ante sus ojos por la profunda migración rural-urbana, que fue comparada con una invasión pacífica, la cual en cierta forma sustituyó en el imaginario de la elite a la entrada en Caracas de los ejércitos revolucionarios campesinos y provincianos del siglo XIX, a un ritmo alucinante de cambios y desbarajustes en todos los órdenes (...)".

O impulso à urbanização venezuelana certamente está relacionado ao aumento da exploração e exportação do petróleo a partir da década de 1920. No entanto, a atual estrutura urbana marcada pela concentração populacional em poucas cidades costeiras remete a ciclos econômicos anteriores ao petróleo, também vinculados à exportação. 


\subsection{Concentração Urbana e Economia Agroexportadora}

Antes que a agricultura para exportação se tornasse a principal atividade econômica, a concentração urbana em torno dos principais portos já se configurara, ao redor da atividade de extração de matérias primas e envio ao continenente europeu (Amaya, 1999: 173). Mas será com a atividade agroexportadora que a concentração urbana irá se consolidar, fazendo de Caracas o principal pólo e Maracabibo um pólo secundário. A manutenção da economia voltada à exportação irá aprofundar a concentração urbana, fato que ainda seria agravado durante o predomínio da economia petroleira. Segundo Ríos e Carvalho (1999), durante mais de quatro séculos a agricultura de exportação representou a única fonte geradora de excedentes significativos dentro de um funcionamento econômico pouco diversificado e dependente do mercado internacional. Segundo estes autores, "Las claves más importantes para apreciar el caráter concentrador que desde el punto de vista socioeconómico y espacial presenta el proceso sociohistórico venezolano en el período agroexportador, se encuentran en las características que asumió la organización de la producción a partir de un acceso diferencial al uso y control de los recursos productivos y, en consecuencia, de una participación desigual en la apropriación del excedente" (1999: 49).

A concentração urbana se relaciona com a estrutura fundiária do latifúndio. Héctor Silva Michelena (2006: 4) destaca dois autores marxistas fundamentais na interpretação do campo na Venezuela. Miguel Acosta Saignes, que publicou sua obra Latifundio² em 1938 pela Editora Popular no México, sustentava a importante tese de que o latifúndio não consiste na sua extensão territorial, mas nos tipos de relações sociais que nele prevalecem. Como conclusão, Acosta Saignes propõe uma reforma agrária radical que, de acordo a Silva Michelena, permearam todas as ações públicas no tema, sobretudo durante o período democrático de 1945-1948, conhecido como triênio adeco e quando se inicou a reforma agrária. Outro autor importante foi Salvador de la Plaza que, com enfoques semelhantes a Acosta Saignes, aprofundou o enfoque jurídico e colocava o problema da renda da terra: "en tanto que el trabajo agrícola realizaba su producción en el mercado internacional, dando lugar así a una renta internacional que era captada sólo por los terratenientes". De la Plaza também conclui com a proposição da reforma agrária com uma obra especial sobre o tema, intitulada $L a$ Reforma Agraria ${ }^{3}$.

Michelena (2006: 9), ao apresentar a obra de ambos autores, coloca em questão qual o impacto da renda da terra naquele momento: "Formulémonos ahora una interesante pregunta: cuánto pesaba, en el valor de las exportaciones agrícolas originadas en la agricultura de plantación, la renta de la

\footnotetext{
${ }^{2}$ ACOSTA, Alberto. Latifundio. Edición especial de la Procuraduría Agraria Nacional. Caracas. 1987.

${ }^{3}$ DE LA PLAZA, Salvador. La Reforma Agraria. Caracas: Ediciones Pensamiento Vivo. 1959.
} 
tierra? Este estudio no se ha hecho para Venezuela como sí lo hizo, para la Argentina, Guillermo Flichman. En relación con el petróleo sí lo han realizado Baptista y Mommer"4.

Além da distribuição desigual dos meios produtivos, a forma de organização do trabalho é central para a compreensão da função concentradora que a agricultura de exportação desempenhou na Venezuela. Neste sentido, é necessário entender a função que o chamado Conuco exerceu na organização do trabalho agrícola. Nos conucos o trabalhador tinha direito a uma pequena porção de terra, onde podia se apropriar da produção para a subsistência de sua família. Desde o início da República foram ditadas disposições com a intenção de impedir a livre mobilidade do trabalhador, cuja vigência durou até a década de 1930. O controle da mão-de-obra pelo fazendeiro em parte remete à situação dos trabalhadores rurais imigrantes no Brasil; segundo Ríos e Carvalho, nos conucos "el trabajador se veía obligado a vender su fuerza de trabajo al hacendado, en los momentos requiridos, a cambio de un salario que le permitía vincularse a un limitado circuito comercial en el cual con frecuencia el hacendado actuaba como comerciante".

Ríos e Carvalho (1999:42) defendem a tese da vinculação orgânica entre a agricultura para exportação (plantación) e a agricultura de subsistência (conucos), um binômio que formava a base do funcionamento das fazendas. Era a forma como os proprietários das fazendas controlavam a mão-deobra e diminuíam o custo de produção, impedindo a formação de uma classe de trabalhadores assalariados, e mantendo formas de subsistência que possibilitavam o excedente da produção agrícola diretamente voltada ao capitalismo internacional. Podemos perceber como a estrutura agrária venezuelana reproduzia a lógica recorrente na América Latina de dependência orgânica entre as formas “atrasadas” e “modernas” como forma de inserção do país no capitalismo internacional.

Segundo Elba Rísquez (1987), a independência da Venezuela em 1810 foi o meio pelo qual a classe dos grandes proprietários "criollos" utilizaram para tomar o poder político: "estos mantienen en vigencia el sistema de tenencia de la tierra y las relaciones latifundiarias. (...) Al lado del terrateniente, está el 'empresario comerciante y banquero', altamente vinculado a los intereses extranjeros. Por un lado, las relaciones latifundistas subsisten donde la producción agrícola se queda en os límites de los terratenientes y sus conuqueros" (Rísquez, 1987: 15).

Em termos urbanos, o não assalariamento e restrição à mobilidade do trabalhador impediram a formação de povoados fora das unidades produtivas, fazendo com que a estrutura urbana do país se concentrasse nas poucas cidades vinculadas aos portos e ao comércio internacional, como Caracas, Valência e Maracaibo.

O vínculo da economia venezuelana com o exterior é portanto determinante na formação concentrada do sistema urbana venezuelano. Tanto assim que, muitas vezes, a infra-estrutura para a formação

\footnotetext{
${ }^{4}$ FLICHMAN, Guillermo. La renta del suelo en el desarrollo agrario argentino. Siglo XXI Editores. Mexico. 1976 e BAPTISTA, A. e B. MOMMER. El relevo del capitalismo rentístico. Hacia un nuevo balance de poder. Caracas: Fundación Polar. 2004.
} 
deste sistema foi realizada diretamente pelo capital estrangeiro. Na década de 1880, antes mesmo de se iniciarem as explorações petroleiras, investidores britânicos e alemães construíram as linhas ferroviárias que conectavam Puerto Cabello com Valencia e o porto de La Guaira a Caracas (Amaya, 1999:178). O eixo formado por Puerto Cabello-Valencia-Caracas-La Guaira constitui hoje a mais importante concentração urbana do país. Segundo Amaya (1999: 179). "el desarrollo de las redes locales de transporte no contribuyó a la integración del espacio económico de Venezuela, sino que por el contrario reforzó el patrón de economias regionales orientado hacia los mercados externos".

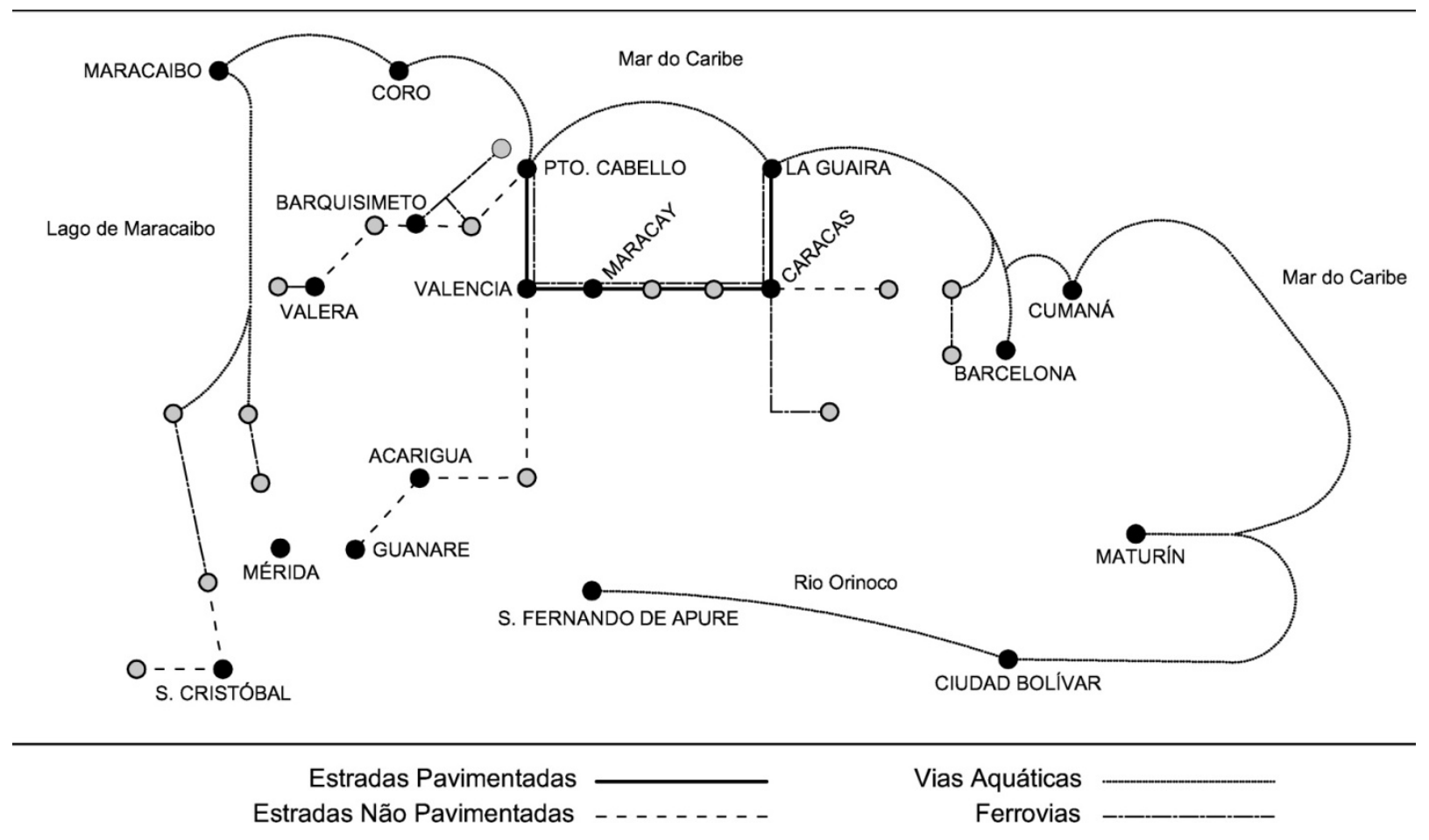

Fig. 1: Sistema nacional de mobilidade em 1920 na Venezuela Redesenhado a partir de Négrón (1982). Fonte de Informações: Cordiplán.

Durante a crise do período agroexportador na década de 1920, quando um porcentagem pequena da população ainda vivia no campo, o padrão urbano concentrado já se desenhara no território venezuelano. A economia baseada no petróleo irá aprofundar essa concentração, agora intensificada pela urbanização acelerada nas décadas de 1940 e 1950 e consequente transformação da Venezuela em um país urbano.

\subsection{Urbanização e a Economia de Exportação de Petróleo}

A lógica territorial da economia agroexportadora, marcada pela concentração urbana, se encaixou às novas necessidades da economia do petróleo. Em comum, ambas economias eram voltadas à exportação, o que possivelmente constitui uma das causas para o encaixe das necessidades territoriais de economias tão distintas como a agricultura e o petróleo. 
A crise da economia agroexportadora e a ampliação da atividade petroleira marcarão a passagem da sociedade venezuelana ao capitalismo atual. Segundo estudo da Equipo Sociohistórico del CENDES (1993), podemos classificar essa passagem em dois grandes períodos (Carmona e Español):

- Período de criação das condições para a estruturação capitalista na formação venezuelana, compreendido entre 1920 e 1950. Momento de desestruturação da economia agroexportadora, que culminou com a crise internacional de 1929, articulação da exploração petroleira mediante a penetração de capital estrangeiro, desenvolvimento de um novo modelo de acumulação e um processo acelerado de urbanização que começa a absorver a renda captada pelo circuito internacional.

- Período de consolidação capitalista na sociedade venezuelana na segunda metade do século $X X$. Caracterizada pela implementação de uma base industrial mediante o modelo de substituição de importações, consolidação do modelo rentista-distributivo, e conformação de uma estrutura urbana dominante.

\section{PERÍODO 1}

Segundo Mieres (1962 apud Michelena, 2006:10), a implantação petroleira se realizou sobre uma estrutura econômica latifundiária, sem negá-la: dados os altos custos da exploração petroleira (aquisição de terras, perfuração, elevada técnica de transporte e refinamento), esta ocorreu por meio da grande concentração de propriedade verticamente integrada, com a formação de empresas e consórcios internacionais. Segundo Ríos e Carvalho (124), em 1940 a Standard Oil chegou a ter 14 milhões de hectares de concessão nos Estados Monagas, Sucre e Zulia. Em meados da década de 1940 cerca de 9\% do território nacional havia sido outorgado a particulares.

Se por um lado a sociedade venezuelana sofreu alterações radicais a partir da exploração do petróleo, por outro o predomínio da função exportadora na economia nacional permaneceu. A permanência da exportação como base da economia explica o "encaixe" do padrão urbano concentrado advindo da economia agrícola às novas necessidades da economia petroleira. Como demonstra Milton Santos em texto sobre a Venezuela, a tendência concentradora se intensificava à medida em que se aprofundava a atividade petroleira, em paralelo ao aumento de fluxos:

"Se quiséssemos definir sucintamente as condições atuais da organização do espaço na Venezuela e, de modo geral, nos países de Terceiro Mundo, deveríamos talvez dizer que eles são objeto de duas tendências simultâneas e paralelas, embora aparentemente opostas. De um lado, há a tendência segundo a qual os fatores fixos capital constante representado por objetos geográficos - se tornam dia a dia mais volumosos e concentrados no território. De outro, há a exacerbação de todos os fluxos: de pessoas, de capital e da mais valia, de produtos e mercadorias, de 
mensagens e de ordens. O caso da Venezuela é, sob esse aspecto, extremamente signficativo". (Santos, 2010: 120)

Segundo Ríos e Carvalho,

"En correspondencia con los principales intereses que dominaban y determinaban la política del Estado sua acción se orientó, por una parte, a facilitar la operación plena del capital extranjero - ahora interesado en un producto estratégico para el desarrollo del capitalismo en los centros - y que venía a satisfacer la permanente demanda de la clase dominante durante el siglo XIX, que veía en las capitales y en la población extranjeros la solución a los problemas del atraso (...). De esta manera la política del Estado a la vez que era resultado de la dinámica concentradora, que espacialmente tenía como eje la zona central y Caracas particularmente, contribuía a mantener y a acentuar el desigual desarrollo espacial y socio-económico de la formación social venezolana". (Ríos e Carvallo, 1999: 93)

Durante a expansão da exploração petrolífera, além do incremento populacional das grandes cidades, a concentração urbana se deu também pela diminuição populacional daquelas que estavam fora da influência da exploração petrolífera ou da administração de seus ingressos (Bello e Marcano). O quadro a seguir demonstra que, no lapso de apenas 10 anos, entre 1926 e 1936, diversas cidades venezuelanas perderam significativa parcela de suas populações.

\begin{tabular}{lrr}
\hline Centro Poblado & 1926 & 1936 \\
\hline La Victoria & 17.336 & 7.987 \\
\hline Villa de Cura & 14.202 & 7.536 \\
\hline Upata & 9.633 & 3.794 \\
\hline Guacara & 9.300 & 3.098 \\
\hline San Carlos de Cojedes & 11.931 & 3.075 \\
\hline Tinaquillo & 17.139 & 3.789 \\
\hline Altagracia de Orituco & 12.004 & 3.491 \\
\hline Valle de la Pascua & 11.053 & 4.870 \\
\hline Zaraza & 19.804 & 3.871 \\
\hline Duaca & 28.719 & 3.743 \\
\hline Quibor & 14.197 & 3.147 \\
\hline El Tocuyo & 19.142 & 5.365 \\
\hline Tovar & 11.069 & 3.639 \\
\hline Guatire & 11.003 & 4.273 \\
\hline Ocumare del Tuy & 12.524 & 6.496 \\
\hline Maturín & 14.628 & 7.498 \\
\hline Rio Caribe & 25.428 & 6.110 \\
\hline Carúpano & 25.679 & 16.088 \\
\hline Rubio & 16.003 & 3.617 \\
\hline Boconó & 21.775 & 3.617 \\
\hline San Lázaro & 9.086 & 3.393 \\
\hline Nirgua & 36.835 & 4.360 \\
\hline Yaritagua & 15.974 & 5.495 \\
\hline Barinitas & 6.884 & 3.397 \\
\hline San Carlos del Zulia & 6.920 & \\
\hline & & \\
\hline
\end{tabular}

Quadro 1: População em Centros Urbanos (1926 e 1936).

Fonte: Miguel Izard. Estadísticas para la Historia de Venezuela.

Ediciones de la Universidad Los Andes. apud Bello e Marcano. 
Rodolfo Quintero, em livro de 1972 denominado "Antropologia del Petróleo", caracteriza as cidades petroleiras como instituições coloniais onde se exerce um controle econômico e político que assegura "la acción colectiva de sus miembros bajo la autoridad de una empresa poderosa dirigida desde la metrópoli, que dispone de reglamentos e impone sanciones para conseguir mayor productividad mediante el esfuerzos de todos" (Quintero, 2014: 71). Quintero explica a forma como as cidades petroleiras afetam todo o território ao redor: "Centro de perturbación de comunidades cercanas por su tendencia a la acumulación de capitaltes, tierra y fuerza de trabajo que atrofia a sectores económicamente débiles: pequeños propietarios y comerciantes modestos que terminan dependendo del campo petrolero, formando reservas de mano de obra disponible según los planes de las compañias" (Quintero, 2014: 72).

É importante notar que o impacto do petróleo na economia venezuelana desencadeia transformações profundas na dinâmica econômica e social de forma genelizada, tendo na propriedade da terra um dos elementos fundamentais na circulação do capital proveniente do petróleo, como demonstra Elba Rísquez (1987):

"La Venezuela a que llegó el petróleo, era una Venezuela de tierras extendidas propiedades; ante su transformación de país rural a país urbano, con el engrandecimiento de las ciudades por el fluir de mano de obra a Caracas, campos petroleros y ciudades cercanas y capitales de los Estados, se ocasiona que estas extensiones que sólo tenían valor nominal, se demanden y se valoricen espetacularmente; de este modo, los dueños de esas tierras las venden y obtienen así capitales para dedicarse al comercio y a la implantación de incipientes actividades industriales. Se presente así un nuevo tipo de empresario dedicado al comercio de exportación y el incipiente industrial de 1938 y 1940. Para este momento puede decirse que el capitalismo ha llegado a Venezuela".

Se durante a fase agroexportadora as cidades concentravam a maior parte dos excedentes produzidos no campo, a partir da exploração do petróleo as concentrações urbanas passaram a abrigar novas atividades econômicas, como a administração pública, construção de infra-estrutura, serviços e comércio. O crescimento urbano passava então a depender das atividades vinculadas, direta ou indiretamente, ao ingresso petroleiro captado pelo Estado. Isso explica porque as cidades capitais dos Estados, pela relação com o Estado central, experimentaram um leve crescimento. Tal fato, ao invés de indicar a formação de uma economia regional ao redor das cidades pequenas e médias, fora mais uma consequência do padrão urbano concentrado ao redor do Estado rentista.

Com o aprofundamento da exploração petrolífera mudanças profundas ocorrerão na sociedade venezuelana; quanto à posição do Estado na sociedade, ocorrerá uma inversão fundamental: se 
durante a economia agroexportadora o Estado era dependente da atividade privada por meio da tributação, com a passagem para a economia petroleira a atividade privada passa a depender diretamente das ações do Estado, o qual se transforma no principal indutor de diversas atividades a partir de seu poder econômico enquanto tributador das empresas de petróleo. Segundo Ríos e Carvalho (191), "se parte de una situación que impedía al Estado desempeñar una acción significativa y que lo hacía extremadamente dependiente de los sectores dominantes agroexportadores, a una situación en la cual el Estado se convierte en un factor activo que propicia y condiciona las transformaciones que experimenta la sociedad, a partir de ese momento y en particular, su clase dominante”.

A passagem da Venezuela de uma sociedade agrícola a uma nação petroleira moderna ocorreu sob o domínio do governo ditatorial de Juan Vicente Gómez, que governou o país de 1907 a 1935. O "tirano liberal" constituía o "vértice de una abrumadora pirámide de poder" (Urbaneja, 2012: 24), com a qual consolidou a "larga paz" que garantiu o estabelecimento da economia petroleira no país. Com o poder gerado pela ingresso petroleiro, Gómez ampliou o poder do exército central e diminuiu o poder dos grupos oligarcas locais, antes capazes de desestabilizar a economia nacional, e logo "passou de obstáculo a objeto de desejo daquelas oligarquias" (Mendes, 2012). Segundo Urbaneja (2012: 30), o papel do governo de Gómez era basicamente consolidar a paz, construir estradas e modernizar as leis, além de estabelecer uma repressão implacável sobre qualquer tentativa de desestabilização do sistema. No momento de sua morte, Gómez era considerada a pessoa mais rica da Venezuela. Gómez seria sucedido por militares que, como ele, eram provenientes da região dos Andes: Eleazar López Contreras (1936-1941) e Isaías Medina Angarita (1941-1948), cuja saída do poder marcaria o final do ciclo dos militares andinos na Venezuela.

Sob o comando de Gómez, em 1928 a Venezuela já havia se convertido no segundo produtor de petróleo do mundo e o primeiro país exportador (Coronil, 2013: 14). Foi nesse ano que o Banco Obrero foi criado; o Banco será um dos maiores protagonistas na questão urbana em diversos períodos do século XX na Venezuela, com destaque para a construção dos superblocos na década de 1950.

Segundo Ríos e Carvalho, a dinamização da economia a partir do petróleo criou as bases "para una redifinición y diversificación de la estrutura de clases que permite a la clase dominante adquirir un creciente carácter burguês $y$, asimismo, que se conforme un proletariado, tanto urbano como rural". Os autores também argumentam que o "caráter distorcido" que adquire o crescimento da economia como consequência da renda petroleira e da necessidade de sua redistribuição, permite um auge sem precedentes dos setores médios, em grande medida dependente do aparato burocrático do Estado, ainda que também da atividade comercial e dos serviços.

A formação de um mercado interno significativo trará consigo uma demanda maior de mercadorias, que será suprida inicialmente pelo incremento das importações e pela posterior tentativa de industrialização pela via da substituição de importações. As atividades ligadas à importação também 
farão parte da diversificação das classes médias, e terão à frente os mesmos agentes ligados à exportação durante o período agrícola. Enquanto isso, a renda da terra agrícola do ciclo agroexportador era substituída pela renda da terra petroleira.

Segundo Fernando Coronil, "(...) El centro de gravedad de la economía se desplazó de la tierra cultivada hacia el subsuelo, que estaba dado naturalmente; e de los productores agrícolas privados hacia el Estado como propietario de tierras. A la renta del suelo agrícola, que se distribuía mediante la competencia económica entre los productores regionales de café y cacao, la sustituyó ahora la renta del suelo minera, monopolizada y distribuida a discreción por el Estado central".

Iniciava-se o predomínio da circulação da renda sobre a produção de valor, tendência que iria se consolidar como característica intrínseca da economia Venezuelana ${ }^{5}$. Até 1925 o café seguiu sendo o produto de exportação fundamental, mas enquanto na Colombia e no Brasil se fortaleciam as classes sociais associadas a essa atividade, na Venezuela permaneceram estagnadas devido, em partes, à circulação da renda do petróleo na socidade que começou a direcionar as atividades da produção agrícola ao comércio de desenvolvimento do setor imobiliário dos centros urbanos (Coronil, 2013: 125).

O petróleo e a subsequente concentração de recursos financeiros nos centros urbanos ampliou a importância da indústria da construção na economia da Venezuela. Segundo Elza Risquez,

"La concentración de los recursos financieros en los centros urbanos condujo a un rápido proceso de urbanización que dio origen a una incipiente industria de la construcción vinculada a la expansión del desarrollo inmobiliario urbano. La transformación de tierras agrícolas en bienes raíces urbanos se convertió en una vía directa a la riqueza y en la base para la fomación de importantes grupos económicos, esto es, de conglomerados diversificados cuyo centro era una o unas pocas familias vinculadas por lazos de parentesco, de negocios y amistad. A diferencia de lo que ocurrió en muchos países, este proceso no opuso a una burguesía emergente y a una clase terrateniente tradicional." (Risquez, 1987: 135)

\section{PERÍODO 2}

A atividade industrial conheceu a maior expansão na Venezuela durante a década de 1950, sob a orientação da política de substituição de importações. Segundo AMAYA, a partir da década de 1950 se define um novo modelo de desenvolvimento baseado em 4 pilares fundamentais: 1. O valor retornado das exportações petroleiras, 2. O gasto público, 3. A construção pública e privada e 4. A

\footnotetext{
5 "en sociedades donde los ingresos dependen de la mercantilización de la naturaleza, la captura de la renta condiciona la organización de las actividades económicas" (Coronil, 2013: 72).
} 
substituição de importações. É nesta década que se iniciará a implementação dos grandes projetos de indústria básica, como a petroquímica e a sidergurgia.

O surgimento de indútrias médias ocorreu paralelo a desajustes estruturais da década de 1950: desigualdade na distribuição dos ingressos, estrutura de produção, emprego e financiamento, o estanqueamento da agricultura, aumento do desemprego e estímulo à imigração estrangeira. (Risquez, :20)

A localização das indústrias durante este período reafirmou a concentração urbana nos grandes centros. Segundo Amaya, "el hecho de que la industria sustitutiva inicial estuviese dirigida a los bienes de consumo final, conllevó a una vocación de la misma hacia la ubicación cerca de los mercados de las grandes ciudades en las que el ingreso de la población era mayor, debido a la mayor difusión en ellos de la renta petrolera”(1999: 186).

Segundo Barrios, a topografía acidentada de Caracas impedia a implantação de grandes indústrias na região. No entanto, "a partir del arranque del proceso de industrialización sustitutiva la metrópoli caraqueña alcanza cierta figuración dentro del sector de transformación venezolano (...) al especializarse en ramas poco demandantes de suelo urbano y al conformar un eje industrial con capitales regionales vecinas mejor posicionadas para los fines propuestos” (Barrios, 2008: 14).

O proceso de urbanização a partir da atividade petrolífera e da industrialização por substituição de importações levou a Venezuela a um sistema urbano altamente centralizado, concentrado e hierarquizado "la región centro-norte y especialmente la capital nacional (Caracas), debido a su mayor desarrollo industrial, mayor población y mercado, gran concentración de actividades financieras, mayor escala de sus funciones admnistrativas, localización central y mayores economías de aglomeración, tendió a dominar la mayoría de los flujos que se originaban en otras regiones y fuera del país" (Amaya: 188).

Para Ríos e Carvalho, "de esta forma encontramos una franja rectangular que desde Guatire se prolonga hasta Puerto Cabello abarcando a Caracas, su centro principal y donde las ciudades y pueblos van pierdendo buena parte de su especificidad al integrarse a ese toda más amplio. En esa franja se concentra la mayor parte de la población urbana del país; se ubica la mayor capacidad manufacturera, el mayor mercado y los centros de control del comercio de importación, de distribución de mercancías, y de la actividad financiera, así como el eje político-administrativo del país".

O crescimento vertiginoso das cidades venezuelanas não se resumia à migração campo-cidade, e tinha como componente importante a imigração européia. Segundo Almandoz, "además de la inmigración campesina que comenzara a hacerse presente en Caracas desde la irrupción petrolera en los treinta, decenas de miles de españoles, portugueses, italianos y centroeuropeos, así como 'turcos'y 'árabes' del fenecido imperio otomano acenturaron y colorearon, en las décadas siguientes, la dinámica y el 
cosmopolitismo de aquella metrópoli súbita y babélica, motorizada y nueva rica" (Almandoz, 2009: 146).

O aumento dos preços internacionais do petróleo em meados dos anos 1970 impulsionou a imigração interna latino-americana à Venezuela, em um período que ficou conhecido como Venezuela Saudita: "esa inmigración europea predominante hasta los sesenta daría paso a incontrolados contingentes andinos y caribeños en los setenta, empujados por las crisis latinoamericanas que contrastaban con la bonanza de la Venezuela saudita, todos los cuales terminarían engrosando un sector informal y subempleado que ya había cebado a la migración campesina". (Almandoz, 2009: 146).

Segundo Milton Santos,

"O vazio criado no campo e a atração exercida pelos salários moeda forte sobre habitantes empobrecidos dos países vizinhos ajudam a explicar uma volumosa migração de latino-americanos, não apenas de colombianos como no início, mas também de dominicanos, equatorianos, argentinos, uruguaios, chilenos, etc., sem esquecer os cubanos e aqueles procedentes de outros países da América Central. Afirma-se em Caracas que o país teria recebido uns 3 milhões de novos imigrantes desde a elevação dos preços do petróleo: nos últimos cinco ou seis anos, só a cidade de Caracas e sua região metropolitana teriam acholhido a maior parte desses imigrantes, aos quais se acrescentam milhares de venezuelanos". (Santos, 2010: 116)

A Venezuela passava a se tornar um país altamente urbanizado e concentrado. A essas características se somaria a pobreza urbana, informal e subempregada, como parte estruturante da cidade. Era tal a grandeza da favelização nos morros das grandes cidades que se criou o temor expresso na frase anônima: "el día en que los cerros bajen" (González, 2005: 96). Esse dia aconteceria em 27 de fevereiro de 1989, o Caracazo.

\subsection{Urbanização e "Marginalização"}

"A la burguesía, a la clase media urbana de técnicos y profesionales y a la incipiente clase obrera les surgió un nuevo vecino: la masa, entendida como aquel grupo social sin inserción directa ni estable en los circuitos económicos tradicionales o en los nuevos industriales. La propiedad de las nuevas tierras urbanas, alcanzadas por el crecimiento vertiginoso de la ciudad, se mantuvo concentrada en manos de antiguos hacendados criollos y patricios, quienes hicieron su mejos cosecha, con el ensanche desregulado de la ciudad". (Gonzáles, 2005: 96) 
Em meados da década de 1950, o informe "El problema de los cerros en el Area Metropolitana" indicava a existência na cidade de Caracas de 96 barrios, com um total de 53.360 ranchos, habitados por 310.976 pessoas, o que equivalia a 38,53\% da população total da capital ${ }^{6}$ (Frechilla, 1996: 199).

Teolinda Bolívar, pesquisadora que investiga o tema das favelas na Venezuela desde a década de 1970, faz uma interessante intepretação sobre a relação entre os ocupantes das favela e os conucos da Venezuela agroexportadora: "Venían del campo, donde el 'conuco' se hacía en el terreno del dueño de unas de las fincas, haciendas o hatos donde trabajaban y, en consecuencia, hacer un rancho que con el tiempo transformarían en algo mejor, no era para ellos robarse un pedazo de tierra, sino que resolvía una necesidad familiar y social, ya que la ciudad se requería de fuerza de trabajo" (Bolívar, 1995: 34). A ocupação de uma parcela da cidade, local de produção à semelhança da fazenda, era uma condição para a subsistência do trabalhador e, portanto, condição para a produção social e dinâmica da sociedade como um todo. Nesta perspectiva, porque, afinal, a ocupação de uma parcela de terra para a subsistência seria um roubo? Cabe questionarmos em que medida a moradia urbana autocontruída em terreno ocupado acabava por se aproximar mais ao conuco do trabalho não assalariado do que à mercadoria-moradia. Afinal, de forma generalizada, os recursos das famílias não eram suficientes para a aquisição ou aluguel de uma habitação no mercado, enquanto a autoconstrução da moradia acabava por reduzir o custo de reprodução da força de trabalho por meio do aumento das horas trabalhadas pela família na construção da casa. O vínculo orgânico entre formas "atrasadas" e "modernas" do conuco teria adquirido outra dimensão na sociedade urbana? As favelas das cidades venezuelanas talvez reproduzam a "larga periferia" nos termos de Francico de Oliveira, onde predominam "padrões não-capitalísticos de relações de produção, como forma e meio de sustentação e alimentação do crescimento dos setores estratégicos nitidamente capitalistas, que são a longo prazo a garantia das estruturas de dominação e reprodução do sistema" (Oliveira, 2003: 69).

Neste sentido, caberia perguntar em que medida a cultura do conuco foi levada à cidade não apenas pelos dominados, como expressado por Teolinda Bolívar, mas também pelos dominantes, dado que a elite agroexportadora manteve parte de seu domínio durante a passagem à sociedade urbana petroleira, e aos dominantes interessava a formação das favelas e a consequente diminuição do custo de reprodução da força de trabalho.

A passagem do conuco às favelas na Venezuela acaba por nos remeter às interpretações do processo de urbanização no Brasil. Ermínia Maricato (1995) remete a Florestan Fernandes (Fernandes, 1977), à "modernização do arcaico" simultânea à "arcaização do moderno" que constituem a marca do capitalismo periférico, e a José de Souza Martins, para quem "o capitalismo na sua expansão, não só redefine antigas relações, subordinando-as à reprodução do capital, mas também engendra relações não capitalistas igual e contraditoriamente necessárias a essa reprodução" (Martins, 1979 apud Maricato, 1995).

\footnotetext{
${ }^{6}$ A expressão "cerro" equivaleria aos morros no Brasil, assim como "ranchos" aos barracos e "barrios" às favelas.
} 
A influência de autores brasileiros na interpretação da dinâmica urbana foi fundamental na Venezuela. Neste sentido, vale remeter à citação de Paul Singer que os acadêmicos venezuelanos Ricardo Infante e Magaly Sánchez (1979) fazem em artigo de 1979 para explicar a formação das favelas na Venezuela: "Esta extraña situación que ha permitido al capitalismo penetrar la agricultura sin acompañar la modernización, es la causa principal de la marginalidad urbana, puesto que el arcaísmo de la economía rural le permite retener largo tiempo de mano de obra, pero la entrena en una crisis que expulsa finalmente su fuerza de trabajo, que se había vuelto sedentaria, sin que se establezca una relación de continuidad entre expulsión y la absorción por el mercado urbano de trabajo" (Singer apud Infante e Sánchez, 1979). Na década de 1970 as obras de Paul Singer e Lúcio Kowarick, assim como de Carlos Lessa e Helio Jaguaribe, na esteira das leituras de Manuel Castells, influenciaram as principais produções acadêmicas sobre a urbanização na década de 1970 na Venezuela (Lovera, 1994) sobretudo pelas tentativas de interpretação da relação entre dependência e urbanização ${ }^{7}$.

Dentro destes marcos teóricos, o tema da "marginalização" foi central nas interpretações do urbano na Venezuela da década de 1970, em um momento em que o índice de urbanização no país chegava a $80 \%$.

A pobreza urbana, que tinha nos morros de favelas ao redor do vale de Caracas suas expressões mais visíveis, assumiu proporções dramáticas durante a crise social e econômica dos anos 1980.

Segundo González (2005: 107), "la modernización de tres décadas (60-70-80), enmarcada en la democracia institucional del Pacto de Punto Fijo y financiada por petrodólares, había hecho de Venezuela un país de metrópolis".

\footnotetext{
${ }^{7}$ Dependencia y Autonomia en América Latina, de Hélio Jaguaribe, Hacia una crítica del desarrollo latinoamericano, de Carlos Lessa e Tomás Vasconi, Reproducción de la fuerza de trabajo y desarrollo e Urbanización, Dependencia y Marginalidad, de Paul Singer, Explotación y reproducción de la fuerza de trabajo, de Lúcio Kowarick.
} 


\subsection{Caracas: Metropolização, Segregação e Violência.}

A riqueza da Venezuela Saudita da década de 1970 não se expressou no conjunto da sociedade venezuelana. Na cidade de Caracas a população moradora em favelas aumentou durante o boom petroleiro, tantos em termos absolutos quanto proporcionais, conforme o quadro a seguir.

\begin{tabular}{lllll}
\hline População AMC & 1961 & 1966 & 1971 & 1974 \\
\hline População Urbana Total & 1.411 .000 & 1.788 .300 & 2.392 .100 & 2.612 .300 \\
\hline População moradora em Favelas & 336.200 & 523.800 & 941.700 & 1.128 .200 \\
\hline População moradora em Favelas (\%) & $23,8 \%$ & $29,3 \%$ & $39,4 \%$ & $43,2 \%$ \\
\hline
\end{tabular}

Quadro 2: População Urbana na Área Metropolitana de Caracas.

Fonte: Síntese de quadro retirado de Infante e Sánchez (1979). Fonte de dados: OMPU, Población y Empleo, Patrón histórico de localización, 1974-71-66-61, Caracas, 1974. FUNDACOMÚN, Inventario de los barrios pobres del Area Metropolitana de Caracas, Caracas, 1973.

É interessante notar que nos períodos de boom petroleiro há a tendência da disparidade da composição orgânica do capital se ampliar, com uma alterção drástica no setor do petróleo, conforme o quadro a seguir.

Quadro 3. Composição orgânica dos distintos ramos de produção na Venezuela (1972-1976).

\begin{tabular}{lrrrrr}
\hline Ramo & $\mathbf{1 9 7 2}$ & $\mathbf{1 9 7 3}$ & $\mathbf{1 9 7 4}$ & $\mathbf{1 9 7 5}$ & $\mathbf{1 9 7 6}$ \\
\hline Agricultura & 0,92 & 0,93 & 0,9 & 0,89 & 0,91 \\
\hline Manufatura & 4,72 & 4,88 & 4,93 & 4,98 & 5,04 \\
\hline Construção & 2,03 & 1,98 & 1,98 & 1,98 & 1,98 \\
\hline Ref. Petróleo & 7,59 & 9,57 & 19,18 & 19,31 & 20,14
\end{tabular}

Fonte: Frey et. al. 1980.

Fonte de dados: Banco Central de Venezuela (cuadros A-IV-2 Informe Económico BCV 1976).

Assim, a indústria da construção amplia sua importância relativa como principal ramo econômico com baixa composição orgânica do capital, dada a baixa participação da agricultura na economia venezuelana. Isso se soma a uma quantidade significativa de recursos na indústria da construção. Segundo Frey et. al., "(...) un 60 por ciento del volumen de la inversión del Estado se destina a la industria de la construcción y gran parte de estas inversiones estatales provienen de los ingresos petroleros, vinculando así la industria de la construcción con el comercio exterior" (Frey at. al. 1980: $70)$.

A renda da terra petroleira, que avançou sobre a renda da terra agrícola, anda de mãos dadas com a renda da terra urbana e com a atividade da construção civil. Segundo Dorothea Melcher,

"La industria de la construcción llegó a ser la primera industria nacional. El complejo Estado financiero-industria de la construcción - banca - renta del suelo, 
se estableció como el foco dinámico de la economía. Las fábricas de cemento y las empresas constructoras de métodos industriales para las grandes urbanizaciones de Caracas, fundadas por los comerciantes de de materiales de construcción, crecieron vertiginosamente; la especulación en terrenos y apartamentos expandió el negocio de la banca; el Estado gastaba una gran parte de sus ingresos en obras públicas, en carreteras y autopistas, en construcciones de prestigio gubernamental, como grandes hoteles, teleféricos en Caracas y Mérida, faustuosos monumentos nacionales, contratados con empresas privadas de construcción. Estos contratos arrojaban a los gobernantes jugosas comisiones y subornos, llevando así al enriquecimiento de nuevos grupos de la burocracia estatal y formando nuevos sectores del capital nacional que entrelazaron con el capital existente". (Melcher, 1995: 71. grifos próprios)

Seria necessário um estudo específico sobre o complexo Estado financeiro - indústria da construção capital financeiro - renda do solo. Mas certamente o funcionamento desse complexo teve participação decisiva na formação dos grandes territórios de pobreza das cidades venezuelanas.

As décadas de 1980 e 1990 foram marcadas por um dramático aprofundamento da pobreza urbana, agravada pelos ajustes econômicos neoliberais. Segundo González (2005), a renda petroleira como fonte de financiamento começou a manifestar uma queda desde 1981; fora alcançado o ponto máximo da renda petroleira e era inclusive possível prever seu deterioro como fonte do capitalismo rentista, a ponto de entrar na discussão a idéia da Venezuela pós-rentista.

Segundo Cecília Cariola, no final dos anos 1980 estimativas oficiais indicavam em mais de 60\% a proporção de famílias pobres, com mais de $25 \%$ em situação de pobreza extrema, sem acesso sequer a uma canastra alimentaria (Cariola, 1996). Segundo Alberto Lovera, os cálculos e os efeitos sociais da aplicação do programa de ajuste estrutural da economia foram errados - foram muito mais vastos (Lovera, 1996). Segundo Ana Brumlik, a partir de informações da Facultad de Ciencias Económicas y Sociales da Universidad Central de Venezuela, no ano de 1991 a pobreza urbana chegava a 85\%, sendo 35\% de pobreza e 50\% de pobreza crítica (Brumlik, 1996).

Entre 1989 e 1999 na cidade de Caracas o homicídio aumentou em 500\%. Entre os jóvens de 15 a 29 anos, a média era de 222 por 100.000 habitantes em Caracas segundo González (2005: 112), para quem "la gran ciudad era una escena del apocalipsis: una versión de la ciudad negativa asociada a la desintegración social, al conflicto violento a la decadencia".

A metrópole de Caracas, no entanto, abarca uma rede urbana que se estende desde o porto de La Guaira até Puerto Cabello, conformando uma mancha urbana que se estende por aproximamente 200 quilômetros. 


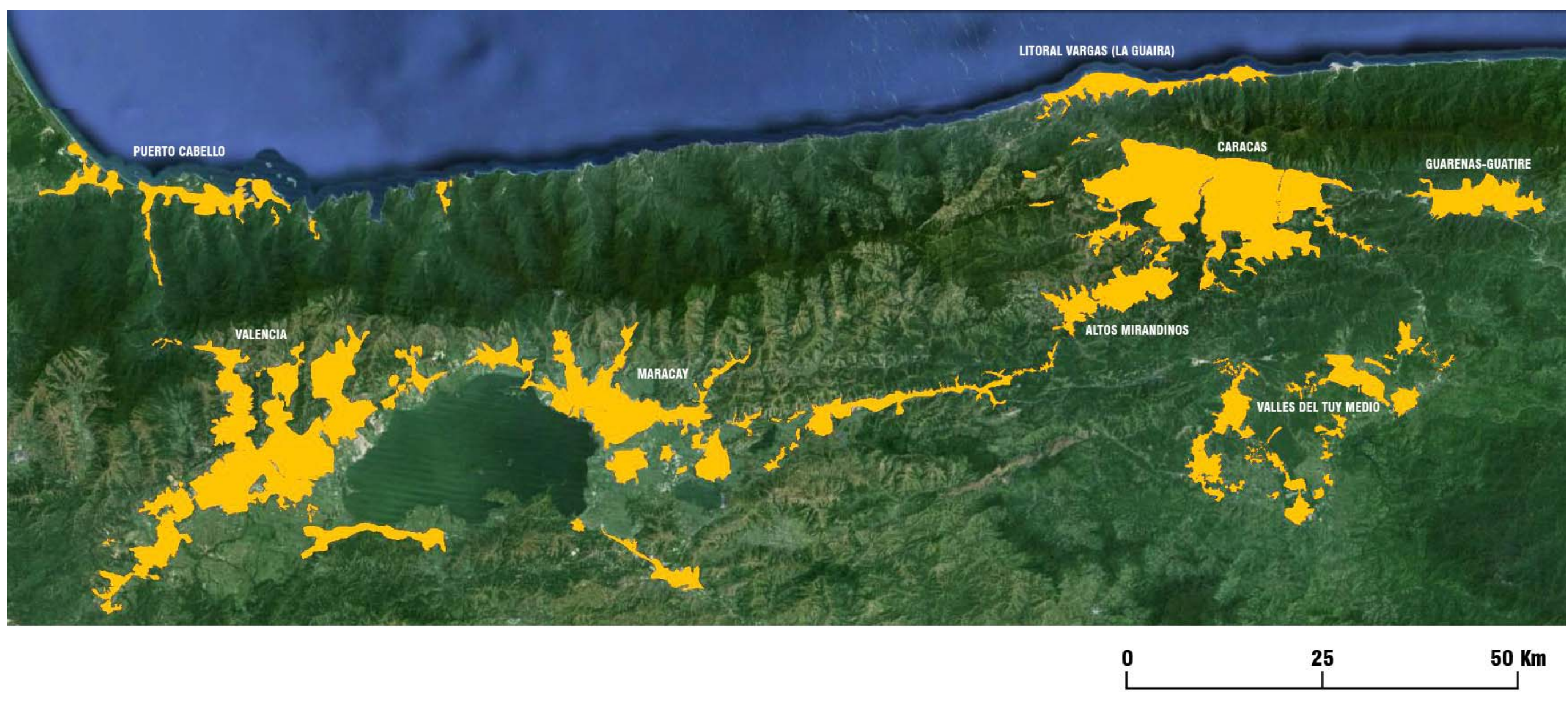

Fig. 2: Corredor Urbano do Centro Norte Costeiro (La Guaira-Caracas-Maracay-Valencia-Puerto Cabello). Elaboração Própria por foto interpretação.

Fonte da imagem: Google Earth. 
Segundo Barrios, a metrópole de Caracas, que aumentou seu nível de primazia urbana nas últimas décadas, mobiliza por meio do aeroporto de Maiquetía cerca de $84 \%$ do fluxo internacional de passageiros, conta com o primeiro porto do país (La Guaira) em relação ao número de passageiros e o segundo em volume de carga, concentra os mais importantes centros universitários e de pesquisa do país, e ao final dos anos 1990 foi escolhida como base regional de operações para "20 conocidas corporaciones transnacionales" (Barrios, 32).

Em Caracas se instalaram grandes empresas vinculadas ao capitalismo global, como a Shell, British Petroleum, Amoco, Hewlett Packard, Placer Dome, BellSouth, Banco Bilbao Vizcaya, Banco Santander, entre outros. Segundo Cariola e Lacabaña (2006), em razão do caráter de capital de um país petroleiro e de novas funções que a cidade de Caracas passou a assumir, diversos trabalhos acadêmicos a localizam dentro da hierarquia de cidades globais.

Em termos intra-urbanos, destaca-se o deslocamento da centralidade urbana, promovida pelo capital financeiro e imobiliário nacional (Cariola e Lacabaña, 2006), em direção ao leste da cidade, onde se conformou um distrito global de negócios. Fez parte desse processo a fragmentação institucional da mancha urbana de Caracas, cuja maior expressão foi a criação de um novo município que abarcava o centro de negócios das corporações transnacionais, o município de Chacao. Nas conversas com caraqueños, com ou sem dados objetivos, muitos opinam se tratar do "mais rico município do mundo".

A fragmentação institucional de Caracas ocorreu com a criação de cinco municípios, e se insere em um processo de reforma do Estado, com a COPRE (Comisión Presidencial para la Reforma del Estado) à frente, e cuja descentralização era um dos fatores centrais. Para Cariola e Lacabana (2006: 20), o município de Chacao, ao se transformar na sede do novo distrito de negócios em correspondência à mudança da centralidade urbana, era "directamente funcional a las nuevas formas de vinculación con la economía global y a las necesidades del capital nacional e internacional".

A mudança de centralidade em direção ao leste, com a instalação de um distrito de negócios global, a exemplo das novas centralidades formadas no quadrante sudoeste da cidade de São Paulo (Villaça, 1998), reafirma as tendências de segregação social no território da cidade de Caracas, no qual a parcela mais rica se concentrará na porção leste da cidade.

A criação de um município à parte para seu novo centro de negócios faz de Caracas um exemplo ainda mais radical de segregação. A divisão de uma grande cidade em vários municípios tornou -se característica comum a todas grandes cidades da América Latina durante os processos de conurbação. A criação do município de Chacao, no entanto, não se vincula ao processo de conurbação, tendo ocorrido tardiamente, na década de 1990. É como se, em São Paulo, ocorresse a criação de um município à parte para a região da Avenida Paulista, Berrini e Faria Lima. 
A divisão territorial foi agravada pelo empobrecimento da população durante o qual este processo ocorreu. Cariola e Lacabaña (2006: 37) caracterizam o período de crise das décadas e 1980 e 1990 como a vinculação do país nos processos de globalização, que acarretou a mudança na estrutura setorial da economia, com a diminuição relativa do setor industrial e crescimento do terciário, afetando negativamente a estrutura do mercado de trabalho, a distribuição de renda e dando lugar a um incremento contínuo da pobreza.

Conformou-se assim quatro grandes divisões na cidade de Caracas: o vale e o morro, o leste e o oeste, em uma paisagem que remete à cidade do Rio de Janeiro. Os morros em Caracas, no entanto, são mais altos, íngremes, e instáveis. Em alguns casos, não se tratam de "morros", mas de regiões de serra em localidades de alto risco sísmico. "Si la naturaleza se opone, lucharemos contra ella y haremos que nos obedezca", disse Simón Bolívar após o terremoto que devastou a Venezuela em 1812. As favelas nos morros, montanhas e serras de Caracas representa a maior provocação à natureza, que foi implacável no dia 15 de dezembro de 1999, "el día que la montaña avanzó hasta el mar", causando a morte de ao menos 1.000 pessoas e o desalojamento de 200.000 durante o dilúvio na cidade de Vargas. A natureza se opôs contra os homens que, ao contrário da frase heróica de Bolívar, nada puderem fazer. Isso ocorreu no primeiro ano do governo de Hugo Chávez.

O atual nível de conflitividade política e social na Venezuela assume em Caracas uma fundamental dimensão urbana. A frase que caracteriza o Caracazo de 1989, "el dia en que los cerros bajaran", traz em suas palavras a importância da cisão territorial. É aquilo que, no Rio de Janeiro, cantava o compositor carioca Wilson das Neves, imaginando o "dia em que o morro descer e não for carnaval".

A conflitividade leste-oeste tem se acirrado durante as chamadas guarimbas, barricadas formadas nas principais avenidas da cidade durante os períodos mais conflitivos. No mais recente ciclo de protestos, em fevereiro de 2014, a Plaza Altamira, principal referência do município de Chacao, se tornou o principal foco de concentração da oposição ao governo de Nicolás Maduro; era, por exemplo, onde se produziam os coquetéis molotov. O Ministerio de Vivienda y Habitat, localizado em Caracas, foi incendiado nestes meses. Antes disso, em outubro de 2002, poucos meses depois da tentativa de golpe de Estado contra Hugo Chávez, um grupo de 14 militares declararam a praça "territorio liberado" onde constituíram uma base a partir da qual realizavam chamados pela "desobediencia legítima" contra o governo chavista.

Atualmente, a segregação territorial de Caracas se dá no nível metropolitano, para além das cisões leste-oeste e vale-morros. Isso ocorreu, em primeiro momento, por meio da expansão urbana em direção à região do Litoral Central (Vargas), e posteriormente em direção aos Altos Mirandinos, Guarenas-Guatire e Valles del Tuy Medio. 


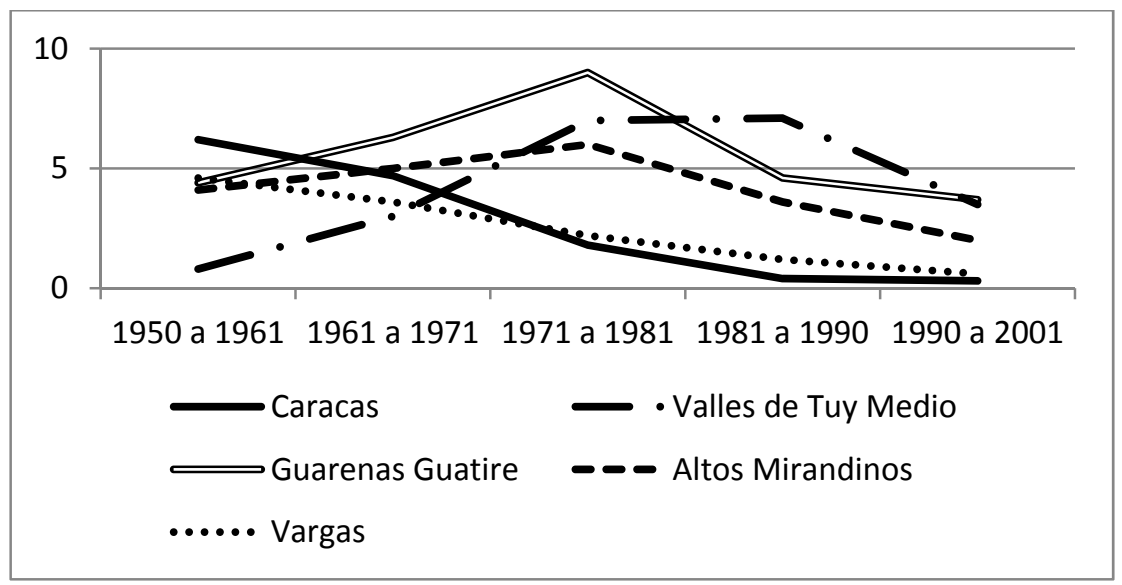

Gráfico 1: Evolução da População na Região Metropolitana de Caracas.

Taxa de crescimento (\%).

Elaboração própria sobre quadro de Cariola e Lacabana (2006).

Fonte de dados: Censos Nacionais.

As favelas

Caracas se localiza em um vale ao pé do Monte Ávila, uma montanha de 1.000 metros de altura, de onde se pode ver o mar. Toda a região norte da cidade é demilitada pela via expressa conhecida como Cota Mil, acima da qual se inicia a área de proteção ambiental do Ávila. Ao redor do vale, a leste, oeste e sul, se localizam os morros, ocupados tanto por favelas quanto por bairros da elite caraquenha.

Metade da população venezuelana vive em favelas, nos chamados barrios. Segundo José Urquijo, "entendemos por barrios aquellas áreas de la zona metropolitana ocupada por viviendas precarias e improvisadas (ranchos en su mayoría), sin previa urbanización y que se desarrollan espontáneamente en forma asimétrica y abigarrada, sin un patrón específico" (Urquijo, 1971).

Segundo Iris Rosas, a superfície ocupada pelos barrios em Caracas é de 7.822 hectares, onde vivem 2.036.701 habitantes, enquanto a superfície das urbanizaciones é de 35.748 hectares, onde vivem 1.697.921 habitantes. Assim, nos barrios encontramos uma densidade média de 260 habitantes por hectare, proporação 5 vezes maior que a média das urbanizaciones, equivalente a 47,48 habitantes por hectare (Rosas, 2008: 97).

As favelas se concentram sobretudo na região oeste da cidade, mas também se destaca a imensa favela do Petare na região leste. Na região oeste, próxima ao centro da cidade e dos mais importantes prédios públicos, como o Palácio de Miraflores, se localiza a favela 23 de Enero. Na região sudoeste outras duas grandes favelas se destacam: La Vega e Antínamo.

Há muito pouco escrito sobre a história das favelas de Caracas. No entanto, é indubitável o papel político destes territórios durante a história da Venezuela. As relações de vizinhança e as necessidades de luta coletiva pela terra, serviços, ou contra a repressão, eram permeadas pela influência de padres da Teologia da Libertação, grupos de guerrilha urbana influenciados pela Revolução Cubana, partidos políticos de diversas correntes, movimento sindical e movimento estudantil. Protagonistas ocultos, pouco da história dos barrios está registrado. 


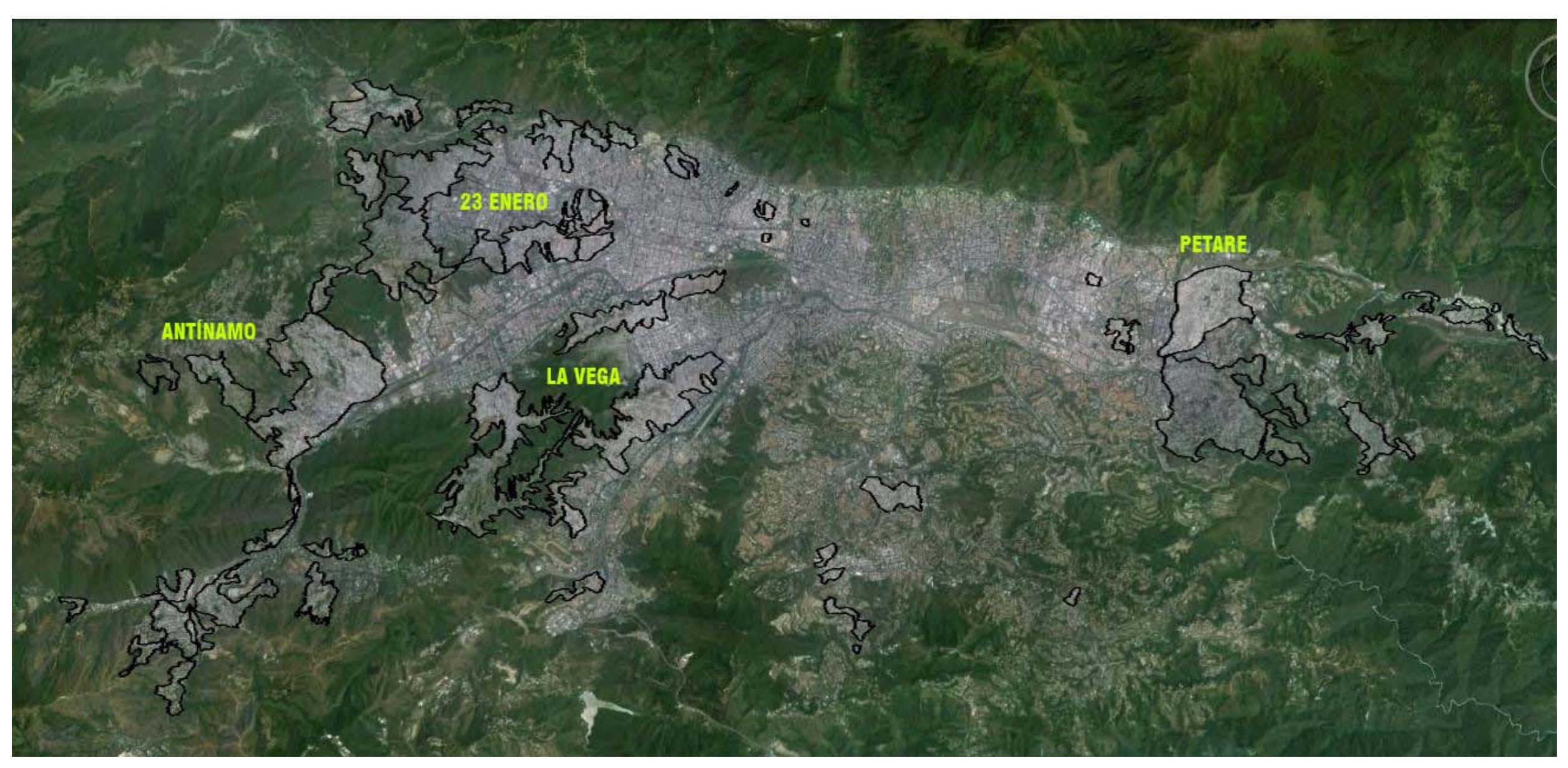

Fig. 4: Perímetro das favelas na cidade de Caracas.

Elaboração Própria a partir de análise de foto aérea (Google Earth) e comparação com Bolívar, 1991. 
As favelas de Caracas impressionam mesmo aqueles acostumados à paisagem das grandes favelas cariocas. A altura dos morros ocupados e a dimensão das favelas fazem do fenômeno venezuelano um exemplo radical. As fotos que ilustram a edição brasileira do livro Planeta Favela, de Mike Davis, retratam Petare e La Vega. Em tabela contendo as "trinta maiores megafavelas" do mundo, Mike Davis indica a favela "Libertador" como a segunda maior favela do mundo, com 2,2 milhões de habitantes. No entanto, essa favela não existe, sendo que 2 milhões é a população aproximada de todo o município Libertador (o maior da Área Metropolitana de Caracas). Considerar todo o município como uma grande favela é um erro grave, mas o fato de tal erro ter sido possível, sem que tenha parecido estranha a informação de uma tal favela de 2 milhões de habitantes, demonstra que o processo de favelização alcançou escalas antes inaceitáveis: a favela do Petare, no outro extremo de Caracas, está alcançando a população de cerca de 600 mil habitantes.

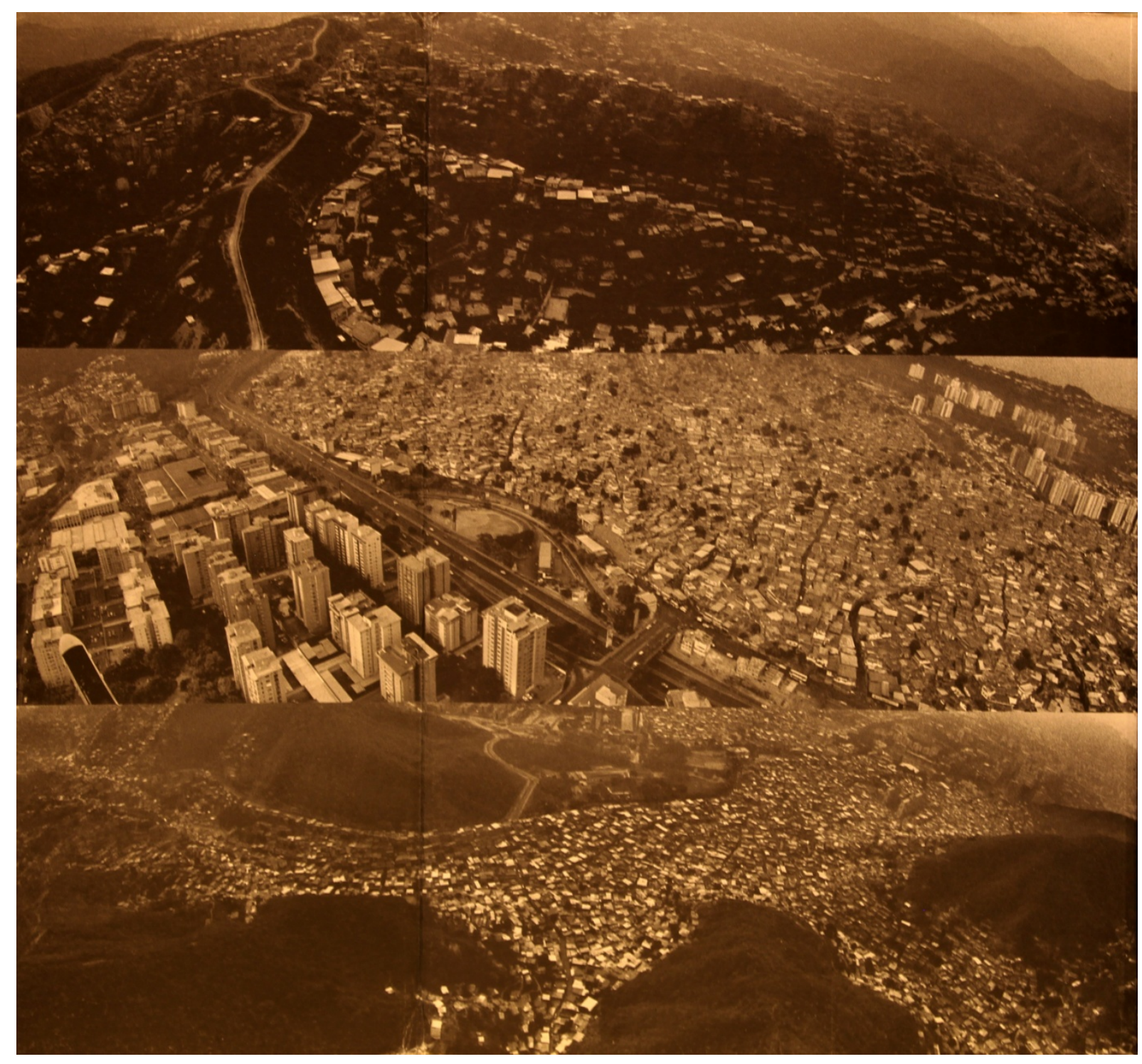

Fig. 5: Ilustrações do livro Planeta Favela. La Vega (acima e abaixo) e Petare (no centro).

Fonte: Planeta Favela, Mike Davis. Fotos: André Cypriano. 
As fotografias em preto e branco que compõe o livro se coadunam à visão do apocalise urbano narrada por Davis. No entanto, para além da torrente de dados de Planeta Favela, interessa conhecer os acontecimentos políticos reais que nascem dessa condição urbana. Em que medida a mais dramática realidade urbana também traz em si os espaços de esperança? Quais são as possibilidades e potencialidades que emergem, nas palavras de David Harvey, da "crise da urbanização planetária e seus múltiplos mal-estares"8? Nesse sentido, a visão apocaliptica baseada em uma caracterização universalizante das favelas sobre o planeta pode prejudicar a compreensão de um fenômeno complexo e contraditório, que só pode ser entendido a partir da proximidade com os territórios em questão.

A Venezuela de Hugo Chávez é um dos temas abordados por Tom Angotti, em artigo que traz uma reflexão crítica ao livro de Davis:

"A visão apocalíptica do mundo de Davis estende-se aos movimentos da esquerda e progressistas, nos quais ele parece considerar apenas como legítimas as organizações de classes industriais tradicionais. Davis aponta, com algum pesar, na direção da reemergência do populismo, como Chávez na Venezuela, como um produto da 'informalidade urbana', como se dissesse - uma vez mais - que a cidade está produzindo um desastre a mais. Em primeiro lugar, Chávez como um fenômeno político, é muito mais complexo. Somando-se ao apoio que recebe dos barrios das grandes cidades da Venezuela, ele tem uma grande base de apoio das elites militares, e subiu ao poder na esteira de um extenso protesto da classe trabalhadora contra a reestruturação neoliberal (Angotti, 2009)".

Como protesto da classe trabalhadora, Angotti se refere ao Caracazo, dia em que a população dos morros desceu ao vale em um processo explosivo de revolta popular. Se trata, indubitavelmente, de um fenômeno urbano que mudou a história recente da Venezuela. O fenômeno das favelas e as revoltas populares serão retomados na última parte do capítulo 2.

${ }^{8}$ HARVEY, David. A crise da urbanização planetária. Blog da Boitempo (blogdaboitempo.com.br). 


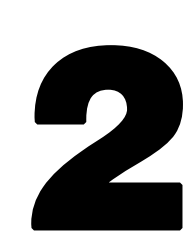

O Petro-Estado e a Cidade:

Breve história de uma relação 


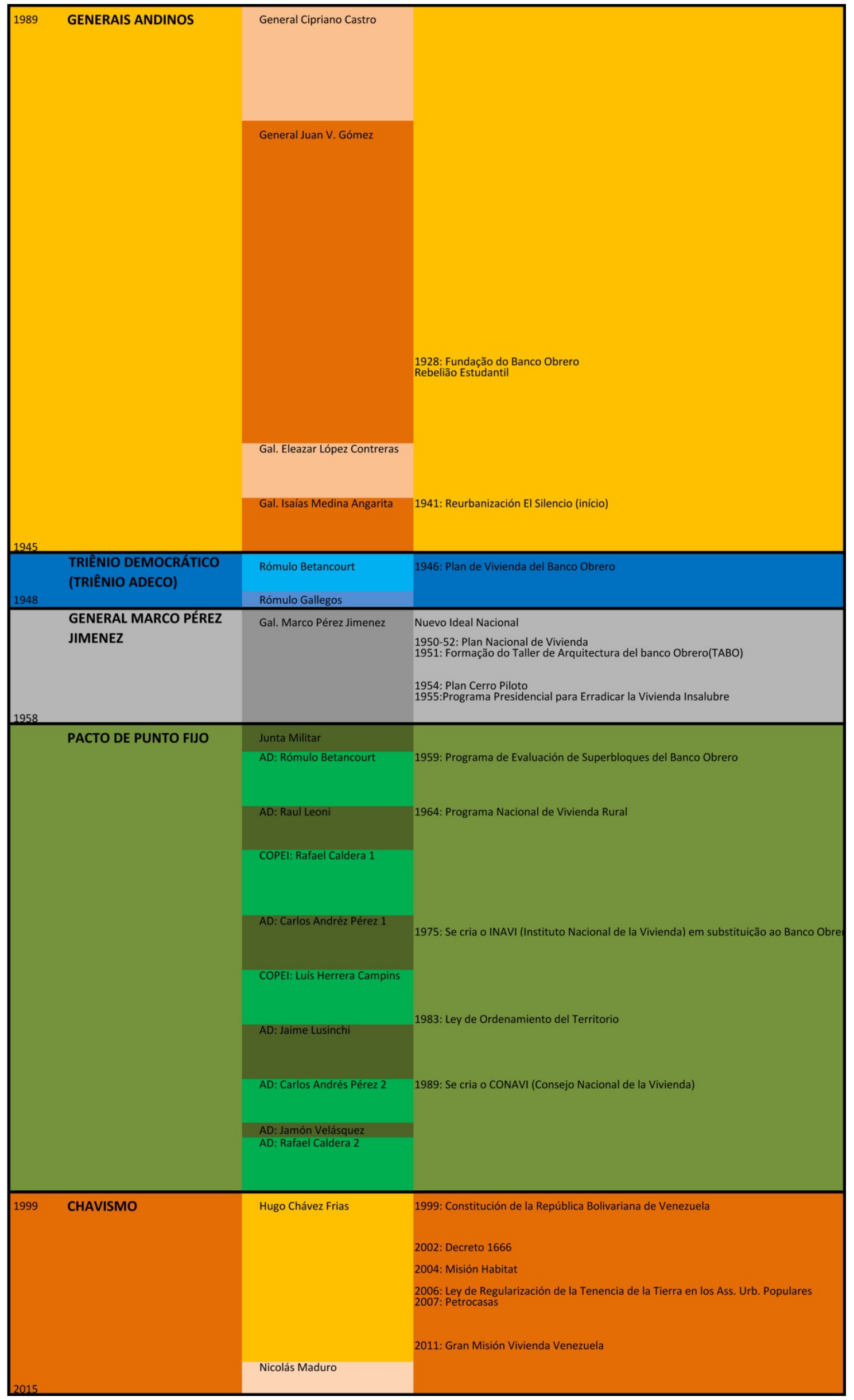




\subsection{Fundação do Banco Obrero e a Consolidação do Petro-Estado}

O primeiro grande depósito de petróleo foi descoberto na Venezuela no ano de 1914. Em 1928 o país havia se convertido no segundo produtor e primeiro exportador mundial de petróleo. Neste ano foi fundado o Banco Obrero marcando o início da atuação estatal no setor habitacional.

Durante todo o período que marcou a virada radical de nação agroexportadora à potência petroleira, a Venezuela foi governada pela General Juan Vicente Gómez, que permaneceu no poder de 1907 a 1935. Nestes 27 anos, lastreado pelo ingresso petroleiro, Gómez se rodeou dos profissionais mais destacados da época, e colocou em prática reformas econômicas que alteraram profundamente as bases econômica e política da Venezuela, ao mesmo tempo em que contribuíam para consolidar o poder de um general caracterizado como cruel e personalista. Nas palavras de Fernando Coronil, "paradójicamente, la industria más moderna del mundo contribuyó a consolidar el gobierno autocrático como modelo del caudillismo latimoamericano tradicional" (Coronil, 2013: 117).

O Banco Obrero foi criado vinculado ao Ministério de Fomento e inicialmente estava voltado para a atuação como ente exclusivamente financeiro. No entanto, com o passar dos anos passou a se encarregar do planejamento, desenho e construção habitacional. O Banco foi criado em um momento histórico fundamental do país, quando o petróleo passou a dominar o cenário econômico venezuelano.

\section{Composição das exportações venezuelanas.}

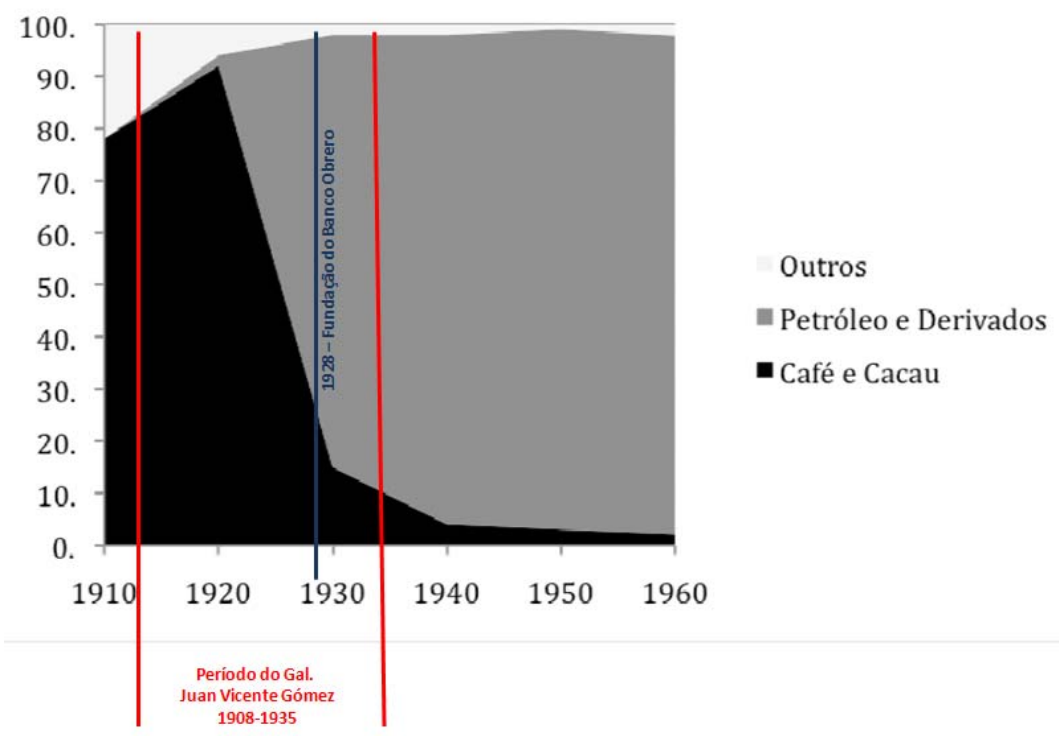

Elaboração Própria.

Fonte: Figueroa, 1974 apud Barros, 2007. Elaboração própria.

A fundação de uma instituição como o Banco Obrero só pode ser compreendida em no contexto histórico de fortalecimento do Estado venezuelano. Flávio Silva Mendes explica a importância do período de Gómez na história do Estado venezuelano: "Durante a ditadura, mais precisamente nos anos 1920, o 
Estado logrou um significativo salto organizativo graças aos primeiros poços de petróleo perfurados no país, que geraram imediata atração de capital estrangeiro. Logo em seguida ocorreu a diminuição do poder de grupos oligarcas locais, antes capazes de desestabilizar a política nacional, em paralelo ao funcionamento das instituições do governo central, sobretudo do exército. Além de consolidar seu poder político, o Estado tornou-se o principal agente econômico do país e o responsável pela distribuição da maior parcela da riqueza nacional. Logo, passou de obstáculo a objeto de desejo daquelas oligarquias". (Mendes, 2012).

Em pesquisa nos arquivos do Banco Obrero, pudemos descobrir nas atas originais de fundação da instituição que a primeira importante transação do Banco ocorreu em um terreno particular do próprio presidente da república, o general Juan Vicente Gómez. O Banco Obrero foi fundado em 2 de julho de 1928. Menos de 2 semanas depois, segundo ata da reunião de 13 de julho do mesmo ano, "Se ordenó escribir una carta al Administrador de los bienes del general Juan Vicente Gómez, proponiendole comprar unos terrenos para una urbanización obrera en esta ciudad". A compra do terreno está registrada na ata do dia 7 de outubro de 1928: "se resolvió comprar en 110 bolívares al Gal. Juan Vicente Gómez, 11.000 metros cuadrados de terrenos y una casa situada en el mismo terreno, que servirá por ahora para guardar los materiales que se necesiten para la urbanización y que será demolida en ser necesario. En dichos terrenos se construirán las 64 casas contratadas con el Dr. Luis Bello Caballero"'.

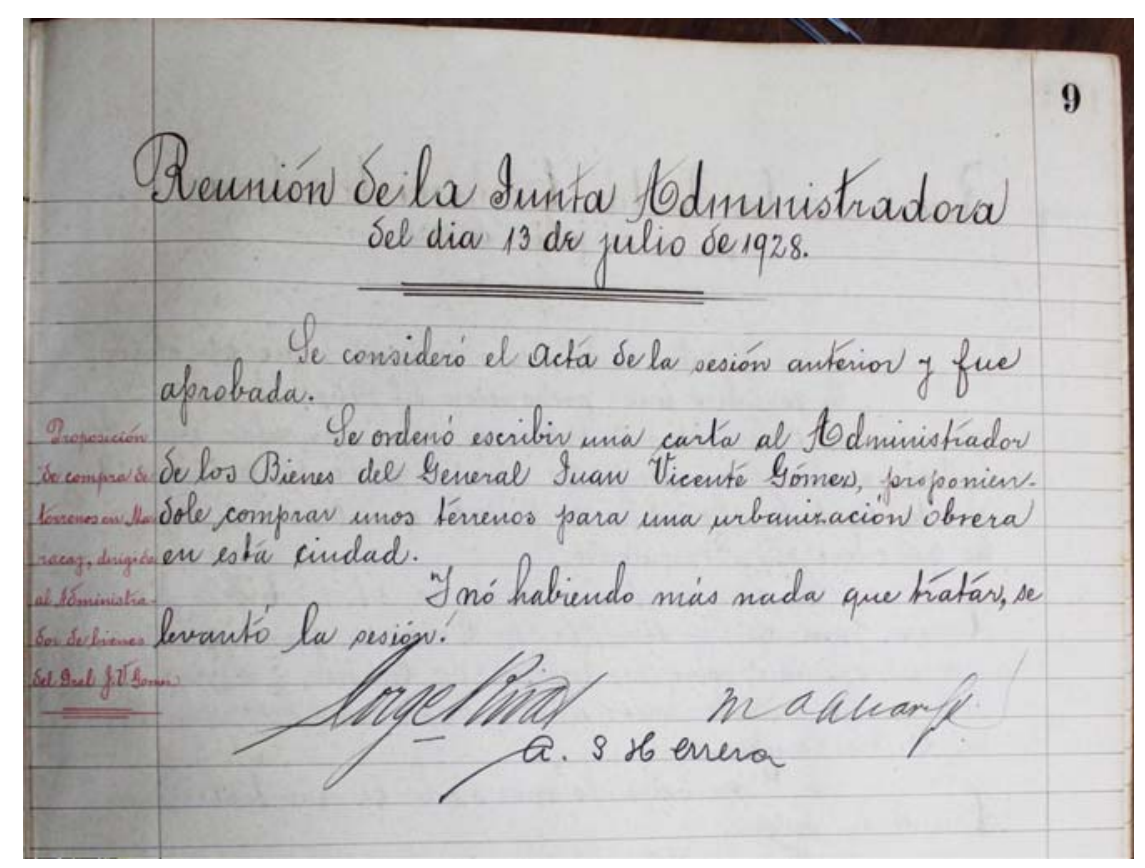

Fig. 6: Foto do livro ata, 13 dias após a fundação do Banco Obrero, ordenando a compra de terrenos do ditador Juan Vicente Gómez. Foto do autor.

\footnotetext{
${ }^{9}$ Fonte: atas do Banco Obrero, atualmente disponíveis na biblioteca do Ministerio del Poder Popular para Vivienda y Habitat.
} 
Segundo Coronil, Gómez "respaldado por estas firmas poderosas [indústria do petróleo], utilizó el Estado como un gobierno privado. Gómez se convertió en el mayor propietario de tierras en Veneuela y uno de los hombres más ricos del continente". Gómez assumiu o controle exclusivo das indústrias de sabão, papel, algodão, leite, manteiga e fósforos, se converteu em único provedor autorizado de carne a Puerto Cabello e outros mercados urbanos, e era o principal acionista majoritário da Compañia Anónima Venezolana de Navegación (Sullivan, 1976: 266 apud Coronil, 2013: 129).

A ascenção da Venezuela a potência petroleira não ocorre desvinculada da figura de Gómez, tendo ocorrido por meio de uma "íntima correlación entre crecimiento de la industria petrolera y fortuna personal de Gómez". Segundo McBeth, "ahora el desarrollo y la inspección de las industrias petrolera y minera estarían directamente vinculados a la ganancia personal de la família de Gómez, lo cual garantizaba que la dirección del país estaba informada al detalle del progreso y los problemas de la industria" (McBeth, 1983:17 apud Coronil, 2013: 130).

No trecho a seguir, Coronil narra como a exploração do petróleo, na relação com a figura de Gómez, alavancou a formação de um Estado forte e centralizado na Venezuela:

"Con la expansión de la producción petrolera, el centro de gravedad de la economía se desplazó de la tierra cultivada hacia el subsuelo, que estaba dado naturalmente; y de los productores agrícolas privados hacia el Estado como propietario de tierras. A la renta del suelo agrícola, que se distribuía mediante la competencia económica entre los productores de café y cacao, la sustituyó ahora la renta del suelo minera, monopolizada y distribuida a discreción por el Estado central. Con este cambio, el poder político, antes fragmentado entre caudillos regionales contendientes, se centralizó. Respaldado por el poder de la riqueza petrolera, Gómez consolidó su poder y definió los cargos clave, distribuyó recompensas y castigos, y llegó a ejercer un control personal sobre todas las ramas de su gobierno" (Coronil, 2013: 130).

Se ao final de seu governo, Juan Vicente Gómez era o principal proprietário de terras da Venezuela, e se a primeira ação do Banco Obrero foi a compra de um terreno de sua propriedade, temos indícios de que por trás da criação do Banco houvessem outros interesses além da construção de habitações populares. Segundo Beatriz Meza Suinaga, "el déficit de alojamiento se exacerba a raíz de la explotación petrolera iniciada en los años veinte, época cuando se crea el Banco Obrero como mecanismo de distribución de esa renta hacia los grupos dominantes, más que como ente encargado de la cuestión habitacional" (Meza, 2008: 34).

Como, afinal, era possível a Gómez e seus aliados direcionar os recursos advindos da tributação da exploração do petróleo às suas finanças pessoais? Além da corrupção pura e simples, tudo indica que a negociação de terras e a construção de obras públicas serviram como corrente de transmissão da renda petroleira à fortuna pessoal do ditador e aliados. A economia do governo de Gómez estava centrada, segundo Elba Rísquez (1987), na construção de obras públicas. Ou seja: à entrada de recursos advindos 
do petróleo seguia a saída por meio de investimentos em obras públicas. O trabalho dos operários, as máquinas e a matéria prima, pagas com recursos públicos, eram cristalizados na materialização de uma rede de infra-estrutura que, além de imprimir dinamismo ao circuito do petróleo, valorizava as terras privadas ao seu redor. Terras de Gómez e aliados.

Além de permitir liquidez aos terrenos de Gómez e, com isso, repassar mais recursos petroleiros do Estado às contas pessoais do general, houve também um interesse político na criação do Banco, fundado no mesmo ano da forte sublevação de estudantes da Univesidade Central da Venezuela, brutalmente reprimida. Os principais líderes desse movimento, como Jóvito Villalba e Rômulo Betancourt, partiram para o exílio. Essa liderança opositora ao regime de Gómez ficou conhecida como a "geração de 1928", que seria fundamental no processo político com o fim da hegemonia andina. Segundo Arturo Almandoz, "además de haber sido la primera agencia oficial creada en Latinoamérica para enfrentar el problema de la habitación pública, el Banco Obrero representó una prueba definida de la parcial revocación del castigo que Gómez habia impuesto a la capital; más alla de la transitoria reconciliación con los rebeldes de 1928, las viviendas del Banco Obrero marcaron un paso significativo para acercar una dictadura hacia un nuevo Estado de bienestar" (Almandoz, 2006).

Nas palavras do próprio Rómulo Betancourt (líder estudantil que assumiria a presidência da Venezuela em 1945):

"La dictadura fue remecida por el turbión del 28. Pero tenía bayonetas, dinero, protección extranjera y hábito de mandar. La oposición estudantil careció de doctrina realmente revolucionária y de apoyo continuado en capas sociales influyentes. Y el despotismo emergió de la crisis arrogante como nunca. En los momentos de desoncierto del clan gobernante ante la rebelión inerme de estudiantado y pueblo, anunció algunos paliativos para el descontento nacional: una Ley de Trabajo, un banco para construcción de casas baratas y otro para la refacción de la agricultura y de cría en ruinas. El Banco Agrícola y Pecuario y el Banco Obrero, las dos instituciones de crédito creadas, sólo sirvieron para hacer desaguar algunos millones de bolívares hacia la clientela política del régimen" (Betancourt, 2007: 67).

Manuel López Villa, ao comentar a fundação do Banco Obrero, não se limita à justificativa dos interesses políticos dada por Betancourt. A tese de que a criação do Banco Obrero fora uma resposta a uma causa concreta que era a rebelião de 1928 foi colocada por Rómulo Betancourt em seu livro Venezuela, Política y Petróleo e compartilhada em cadeia por outros autores. Betancourt, no entanto, é um dos personagens políticos mais importantes da história da Venezuela, tendo formado, depois da volta do exílio, o partido Acción Democrática (AD), com o qual venceu as eleições para presidente, liderando o país nos momentos mais importantes do chamado Pacto de Punto Fijo. Evidentemente o ponto de vista colocado por Betancourt não está livre da disputa política também no campo da narrativa histórica. Nesse sentido, López Villa coloca outros fatores para compreender a fundação do Banco Obrero no ano de 1928: 
"Había, en 1928, los inicios de un auge de la urbanización en Caracas y Maracay, las dos grandes capitales de la época; una industria privada de la construcción comenzando a crecer, que producía aquellas construcciones para la clase obrera con muchíssimas dificuldades, es decir, con la necesidad de un organismo, un banco, que financiase las construcciones de esta industria privada, que otorgase créditos a las empresas de construcción, hipotecas a las viviendas construidas masivamente y todo eso resonaba con estruendo dentro del Gabinete del general Juan Vicente Gómez, en donde desde mucho antes de 1928, quizás desde dos años antes, se discutía la conveniencia de crear un banco obrero y un banco agrícola". (López Villa, 2008: 33)

López Villa chama atenção para a disputa sobre o caráter do Banco Obrero durante sua fundação:

"Se producen una serie de discusiones entre los diferentes ministros, en las que va a resultar victoriosa la tesis de crear un organismo, un banco, y se derrota la tesis de crear un departamento dentro del Ministerio de Obras Públicas para construir directamente las viviendas. Incluso, legalmente se establece que ese banco no puede en ningún caso contruir directamente las viviendas, sino que todo se realice a través de la empresa privada de la construcción" (López Villa, 2008: 33. grifos próprios.)

A disputa sobre o nível e a forma de intervenção do Estado frente a questão habitacional aparece na gênese do processo e irá se reproduzir durantes vários outros momentos históricos da política habitacional venezuelana.

Após a morte de Gómez em 1935, os generais da região dos Andes permanecem no poder até 1945, com Eleazar López Contreras (1935-1941) e Isaías Medina Angarita (1941-1945), propiciando uma gradual abertura política. O país passava neste período por intensas transformações, como o surgimento do Partido Comunista da Venezuela (PCV), em 1931 e o social-democrata Acción Democrática (AD) em 1941, além de sindicatos e uma forte central sindical, a Central de Trabajadores de Venezuela (CTV) em 1936, e de entidades patronais como a Federación de Cámaras y Asociaciones de Comercio y Producción de Venezuela (Fedecamaras) em 1944 (Mendes, 2012).

\section{A construção de El Silencio}

No ano de 1939 é realizado o Plan Monumental de Caracas, conhecido como Plano Rotival. O Plano, realizado pelos urbanistas franceses Henri Prost, Jacques Lambert e Maurice Rotival, com traços hausmanianos, previa a abertura de grandes avenidas sobre o traçada tradicional quadriculado, marcadas por edifícios monumentais. A principal intervenção urbana realizada a partir do plano foi a abertura da Avenida Bolívar, cuja escala marca uma nova fase para o urbanismo de Caracas, condizente ao automóvel e à economia petroleira que se consolidava. 
Uma importante intervenção do Banco Obrero na cidade e na indústria da construção ocorreu com a reurbanização do bairro conhecido como El Silencio, projetado por Carlos Raul Villanueva. Segundo Alberto Sato,

"Un caso ejemplar de la relación proyeto-tecnología constructiva fue la reurbanización de El Silencio, debido a que este emprendimiento se desarrolló en pleno proceso de la Guerra y constituyó una experiencia que puso a prueba la capacidad local de resolver problemas técnicos constructivos y de maquinarias y equipos. El Estado faciltó al constructor privado las herramientas económicas, suministros, mano de obra, etc. para convertirse posteriormente en empresarios de la construcción".

Percebemos a importância da intervenção estatal na reurbanização de El Silencio quando constatamos que a importante Câmara Venezonala de Construcción foi criada nesse ano. Sato explica que "en esos mismos años de la construcción de El Silencio, 1943, se fundó la futura Cámara Venezolana de la Construcción bajo la denominación de 'Asociación de Contratistas de Obras' del Distrito Federal, nucleando básicamente a los constructores del Estado: en síntesis, crecimiento de las empresas constructoras, organización empresarial, sustitución de importaciones e incorporación de nuevas tecnologías, fueran el balance de la década para la industria de la construcción".

Com El Silencio o Estado estimulava a construção civil privada ao mesmo tempo em que eliminava um bairro, localizado ao lado do Palácio de Miraflores, marcado pela prostitução e outras atividades consideradas imorais. 


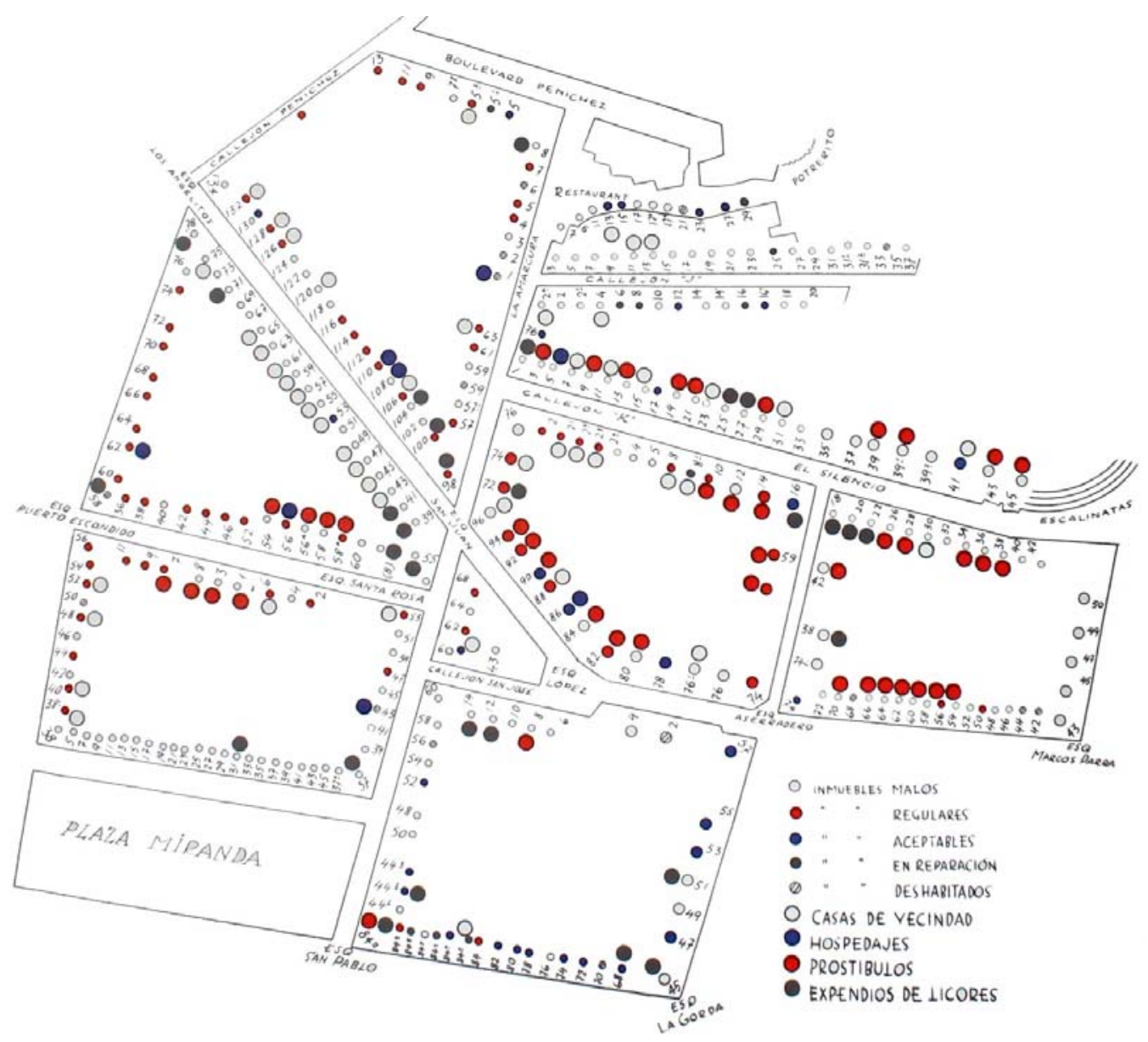

Fig. 7: O bairro El Silencio antes da intervenção urbana.

Fonte: Sola, 1988.

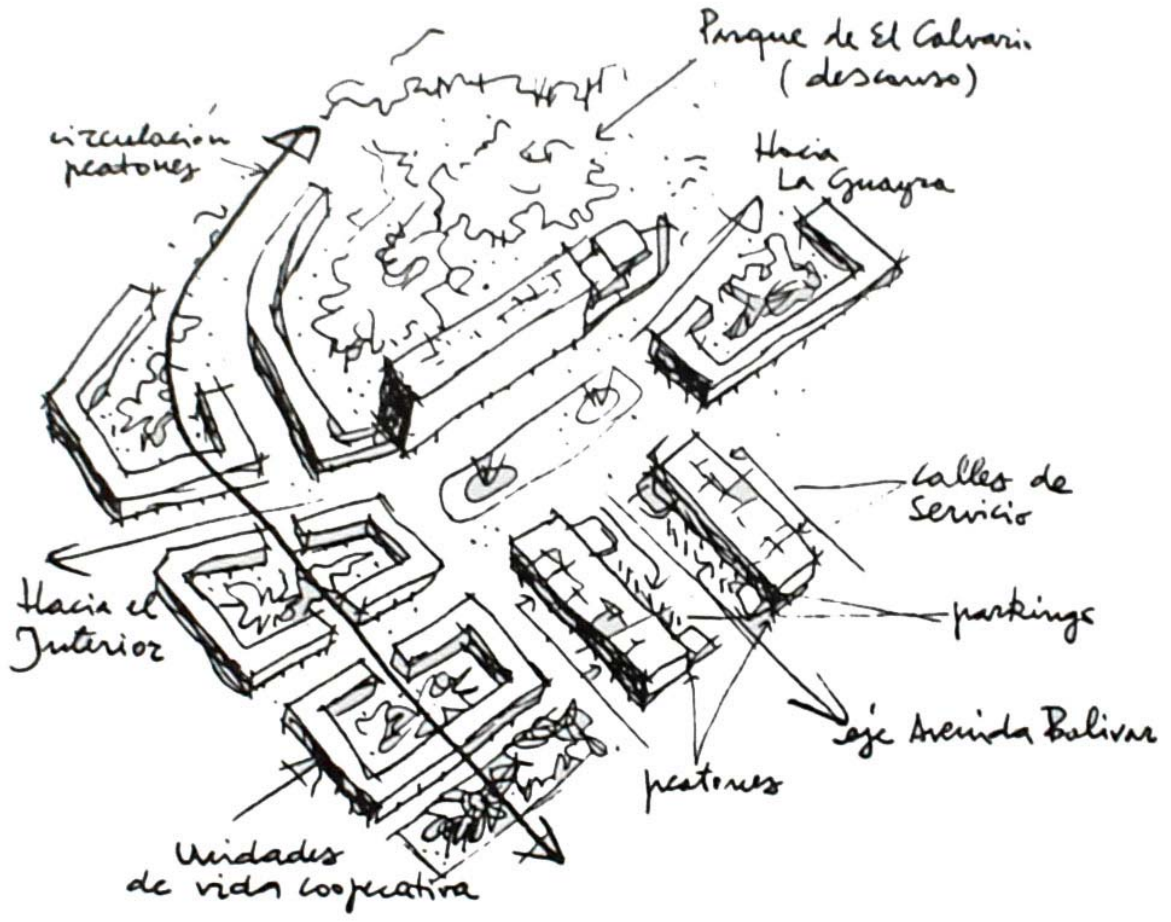

Fig. 8: Croqui de Carlos Raul Villanueva para a Reurbanización El Silencio.

Fonte: Sola, 1988. 
O próprio urbanista francês Maurice Rotival narra sua relação com os principais promotores urbanos, e destes com o arquiteto modernista Carlos Raúl Villanueva, ao mesmo tempo em que demonstra a clara concepção higienista por trás do desenho urbano de El Silencio.

"Carlos Raúl Villanueva era yerno de Juan Bernardo Arismendi, uno de los hombres más ricos de Caracas, riqueza obtenida de la venta de terrenos. Otro rico era Luis Roche y había otros, pero esos dos eran los principales. Roche se ocupaba de los terrenos situados al este del Country Blub, él desarrolló toda esa región hasta Altamira, mientras que Juan Bernardo Arismendi se ocupó de La Florida, onde él hizo los grandes negócios. La Florida era es sitio de predilección de la clase media, pues los ricos estaban en el Country Club, donde ya existían mansiones. Fue allí donde yo me residencié. Yo había comprado una acción en el Country Club y allí viví los mejores momentos de mi vida levantándome a las 5 de la mañana y disfrutando de un lugar tranquilo. Todas las mañanas jugaba golf a las 5:30 am, después me bañaba en una piscina y a las 7:30 am estaba en mi oficina. (...)

En ese momento Rockefeller me pidió que encontrar un lugar para construir un hotel en Caracas. Yo encontré 5 lugares. Entre ellos se escogió el lugar para el Hotel Ávila, onde yo quería meter la Presidencia de la Republica según el plan que estaba proponiendo para la ciudad. Había pensado en un nuveo Miraflores a una altura un poco lejos del Hotel Ávila pero con una vista magnífica sobre la ciudade.

El Miraflores actual estaba cerca de Catia y Catia para ese momento era muy popular y teníamos un grave problema alli que resolver (...); nos habíamos ocupado de Catia, pero era muy difícil orientar el crecimiento hacia allí debido a la alta ocupación de la tierra. Sin embargo, nosotros limpiamos un fuerte sector de allí cuando yo regresé de la guerra. Junto con Villanueva, fue allí donde construimos los grandes edificios para los obreros. Nosotros limpiamos todas las colinas y construimos inmuebles baratos. Junto con Villanueva, en diez años habíamos limpiado todo. En los edifícios que construimos abajo metíamos la gente que sacábamos de los barrios de arriba. Lamentablemente eso no se mantuvo y posteriormente se dejó invadir todas las colinas y espacios que habíamos limpiado y organizado. 


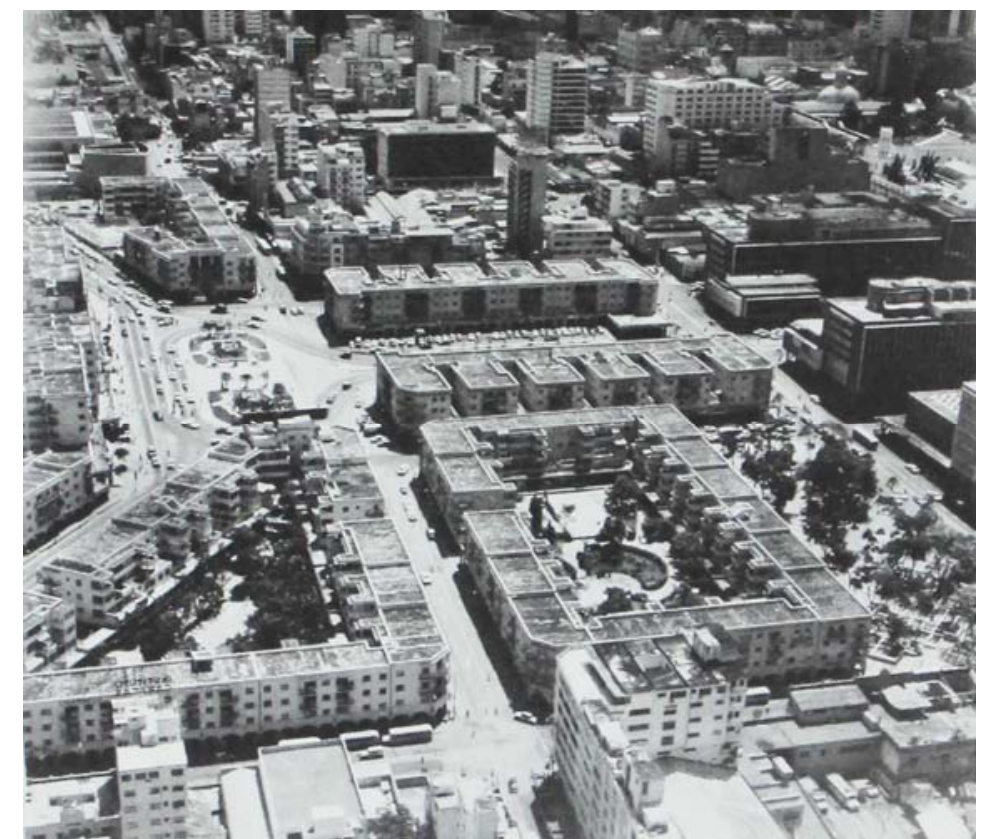

Fig. 9: Reurbanización El Silencio. Arq. Carlos Raul Villanueva.

Fonte: Sola, 1988.

As colinas que Maurice Rotival se refere seriam novamente objeto de intervenção por parte do Banco Obrero, em escala ainda maior, com a implantação dos superblocos modernos na década de 1950. Seria uma nova tentativa, de forma ainda mais radical, de eliminar as favelas. Villanueva participaria novamente, desta vez como o arquiteto oficial do Estado. No entanto, uma vez mais, as favelas voltariam, ocupando os espaços públicos da utopia moderna dos superblocos.

\subsection{O Triênio Democrático (Trieno Adeco)}

O período dos generais andinos chegaria ao fim com um golpe em 1945 liderado pelo partido Acción Democratica, incluídos os quadros políticos que fizeram parte da geração de 1928, e que daria início ao curto período democrático de 1945 a 1948, quando um novo golpe militar daria início a uma ditadura de mais de uma década.

O golpe de 1945 ficou conhecido como "revolução de outubro", e segundo Mendes, "o partido assumiu para si o programa de 'semear o petróleo', expressão cunhadada por membros do governo anterior. Afinados com os rumos da social-democracia mundial no pós-guerra, decidiram converter a renda petroleira em investimento na agricultura e na indústria nacional, sem esquecer a cobertura social do Estado" (Mendes, 2012). Este período democrático ficou conhecido como triênio adeco, em referência ao partido Acción Democrática (AD) que liderou o processo.

Na questão habitacional, o fim da era dos generais andinos também teve importantes consquências, como explica Alberto Sato: 
"Finalizada la Segunda Guerra Mundial, y después de la Revolución de Octubre de 1945, el Estado venezolano reorganizó el Banco Obrero, poniendo al frente del Departamento Técnico y de Construcción al arquitecto Leopoldo Martinez Olavarría e iniciando un período de realizaciones de significación dentro de las políticas habitacionales populares en Venezuela. La racionalización constructiva e un especial énfasis en los sistemas de adquisición de tierras urbanas, crediticios y de otorgamiento de contratos, gerenciados por Martínes Olavarría quien, junto con Carlos Raúl Villanueva desarrolló tipos habitacionales y conjuntos - desde las casas aisladas a los bloques de tres pisos - pueden considerarse como resultado de las experiencias de los primeros congresos del CIAM" (Sato, 1996).

Foi neste período que se criou o primeiro Plan de Vivienda del Banco Obrero (1946-1949). Em 1947 se enuncia na Constituição Nacional o "sistema de ciudades como de interés nacional", e se iniciou o programa de aquisição antecipada de terra para o desenvolvimento urbano ${ }^{10}$.

Na celebração de 1o. de Maio de 1947, o presidente Rómulo Betancourt, que durante o período de Gómez havia liderado a rebelião estudantil de 1928, prometeu a construção de 3.000 habitações para trabalhadores em todo o país e 5 milhões de bolívares em empréstimo à classe média (Coronil, 2013: 190). Com isso, buscava acalmar os ânimos diante da impopular medida de fortalecimento dos poderes do executivo e limitação temporária das garantias constitucionais diante dos riscos de conspirações. Assim, segundo Fernando Coronil, o partido Acción Democrática atuava de uma maneira que chegaria a ser típica da conduta do Estado petroleiro: "constrarrestó la posible impopularidad de esta medida, que eliminava derechos políticos sustantivos, fabricando la ilusión de progreso colectivo mediante la transformación de dinero procedente del petróleo en logros concretos" (Coronil, 2013: 190).

O partido não teria tempo para realizar a construção das 3 mil unidades habitacionais. Em 24 de novembro de 1948 foi derrubado por um novo golpe militar, reduzindo a apenas 3 anos a experiência democrática da primeira parte do século XX. Ainda que a AD houvesse realizado diversas concessões ao setor privado, este ainda via com desconfiança um partido que contava com apoio de operários e trabalhadores rurais, realizara reformas sociais progressistas, e tinha em seu histórico uma retórica socialista. A base social do partido, no entanto, não correspondia à radicalidade de suas propostas: "El primer régimen democrático de Venezuela establecido mediante el sufragio universal murió sin protestas en calles, campos o fábricas" (Coronil, 2013: 197).

\subsection{Marco Pérez Jimenez e o Nuevo Ideal Nacional (1948-1958)}

"we do not believe in conuco [...] we above all are looking for a reasonable agricultural production [...] their rationally worked parcel, with the average ones adapted, of high

\footnotetext{
${ }^{10}$ Fundación Escuela de Gerencia Social http://www.gerenciasocial.gob.ve.
} 
productivity, by tractors but not by just simple sticks. We want they have an appropriate house with hygienic services, television, appropriate cars and that they can send theirs children as the American farmers do to the schools and to the universities...(Martin, 1994: 259)”

\section{Marco Pérez Jimenez}

Com o General Marco Pérez Jimenez se inicia um novo período de restrições democráticas que duraria até o ano de 1958. Em sua passagem pelo poder, Pérez Jimenez elege a construção de grandes obras públicas como o principal objetivo de seu governo.

Para Coronil, "la práctica evidenció que el régimen se concetrava en los signos visibles de la modernidad que consideraba esencia del desarrollo capitalista. Estas encarnaciones concretas del progreso - hoteles de lujo, carreteras, uns siderúrgica, un campus universitario modernista - se entendían al mismo tiempo como símbolos y causa del progreso. Se creía que, transplantándolos de los centros metropolitanos al atrasado suelo local, estos fetiches de la modernidad traerían el progreso a Venezuela" (Coronil, 2013: 230).

Segundo Avendaño Lugo, "el Nueno Ideal Nacional era un compuesto ideológico de liberalismo, positivismo, militarismo tradicional y retórica de partidos democráticos venezolanos". (Avendaño Lugo, 1982: 342 apud Coronil, 2013: 231).

Para Castillo D’Imperio, o projeto econômico de Pérez Jimenez se baseava no discurso do despotismo militar ilustrado, e não na teoria modernizadora do partido $\mathrm{AD}$, tampouco nas doutrinas autoritárias burocráticas desenvolvidas por militares no Brasil ou na Argentina (Castillo, 1990 apud Coronil, 2013: 232).

O Nuevo Ideal Nacional, se fazia referencia a um "ideal", adquiria força menos pelas palavras (a modernização e a transformação do meio físico não eram novidades enquanto idéia) e mais pelas realizações concretas, desta forma estimulando a iniciativa privada da construção civil, conforme aponta Alberto Sato: "El estímulo por las construcciones de gran envergadura alimentada por este sentido particular de progreso, ha sido acompañado por la iniciativa privada que se ha adherido al entusiasmo constructor, en tanto que negocio urbano, como también en tanto que expresión de sociedad moderna". As realizações materiais eram o cimento filosófico do regime de Pérez Jimenez.

Se as obras eram mais importantes que as palavras, a arquitetura deveria cumprir um papel simbólico fundamental:

"La política venezolana de la década, signada por un régimen ditatorial, estimuló el desarrollo de la actividad profesional. El arquitecto trabajó en todos los escenarios posibles y en buena medida, bajo el abrigo del poder político. La tradición edilicia venezolana fundada sobre la acción del Estado desde fines del siglo XIX, orientó sus 
acciones hacia un destino progresista alimentado por el pensamiento positivista entre los cuales la obra material habría de cumpliar el rol protagónico" (Sato, 2010).

O período de Pérez Jimenez foi marcado pela construção de obras públicas monumentais, que até hoje marcam a paisagem venezuelana. A construção de infra-estrutura física saltou nesses anos de 200 para 1000 milhões de bolíavares (Maza, 1977 apud Sato, 2010). A produção da indústria do cimento saltou de 115.784 toneladas em 1945 para 1.871 .678 toneladas em 1958 (Oese, 1979 apud Sato, 2010). Tal ampliação só foi possível porque era acompanhada pelo aumento da produção de petróleo no país, que saltou de 250 milhões de barris em 1944 para 850 milhões em 1957 (Sato, 2010).

Se a modernização do Banco Obrero fora iniciada durante o curto período do triênio democrático, seu aprofundamento ocorreria durante a ditadura de Marcos Pérez Jimenez. É com Pérez Jimenez que, segundo Manuel López, "una febril actividad constructora comienza a desplegarse a través del Ministerio de Obras Publicas y de todos los organismos de Estado relacionados con la industria de la construcción, con el objeto de llevar a la práctica los ideales postulados de la Junta Militar" (López, 1993).

Durante a Junta de Gobierno (1950-1952) foi elaborado o Plan Nacional de la Vivienda, no qual se previa a construção de 12.185 habitações em 15 cidades diferentes. Também é desta época a elaboração do Plan Cerro Piloto (CP), primeira experiência de massificação habitacional, a partir do qual se gerou um "frenesi" construtivo em Caracas a partir de 1955 (Meza, 2008).

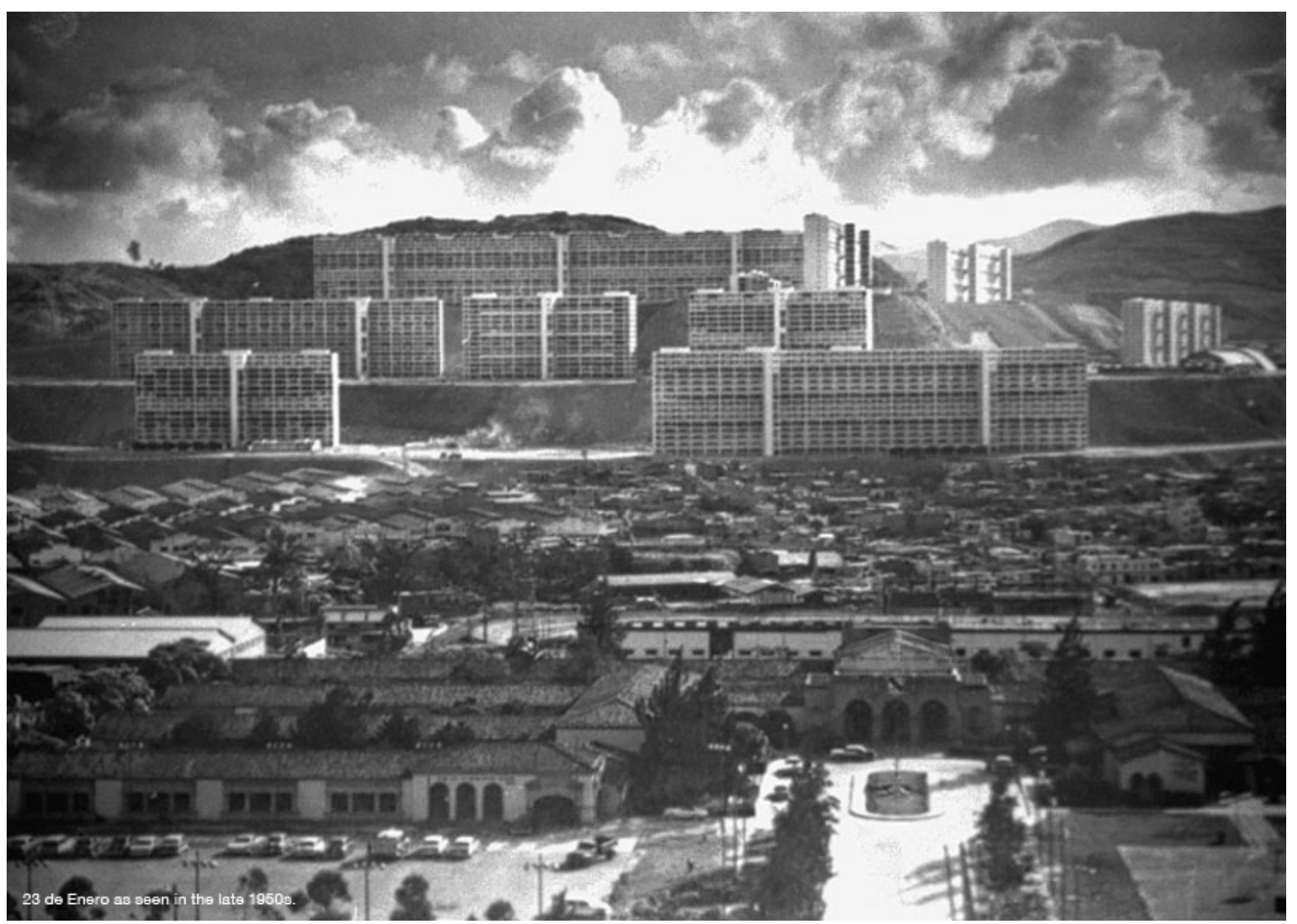

Fig. 10: O centro histório e os novos superblocos de habitação implantados nos platôs. 
As experiências de massificação habitacional estavam claramente sintonizadas com os princípios arquitetônicos que estavam sendo experimentados na Europa, sobretudo por Le Corbusier. O Taller de Arquitectura del Banco Obrero desenvolveu os chamados "superblocos" como modelo arquitetônico para a construção em massa de habitação. Tomaram como referência a Unidade de Habitação de Marselha de Le Corbusier. A Unidad de Habitación Cerro Grande, finalizada em 1954, se tornou o modelo mais conhecido.
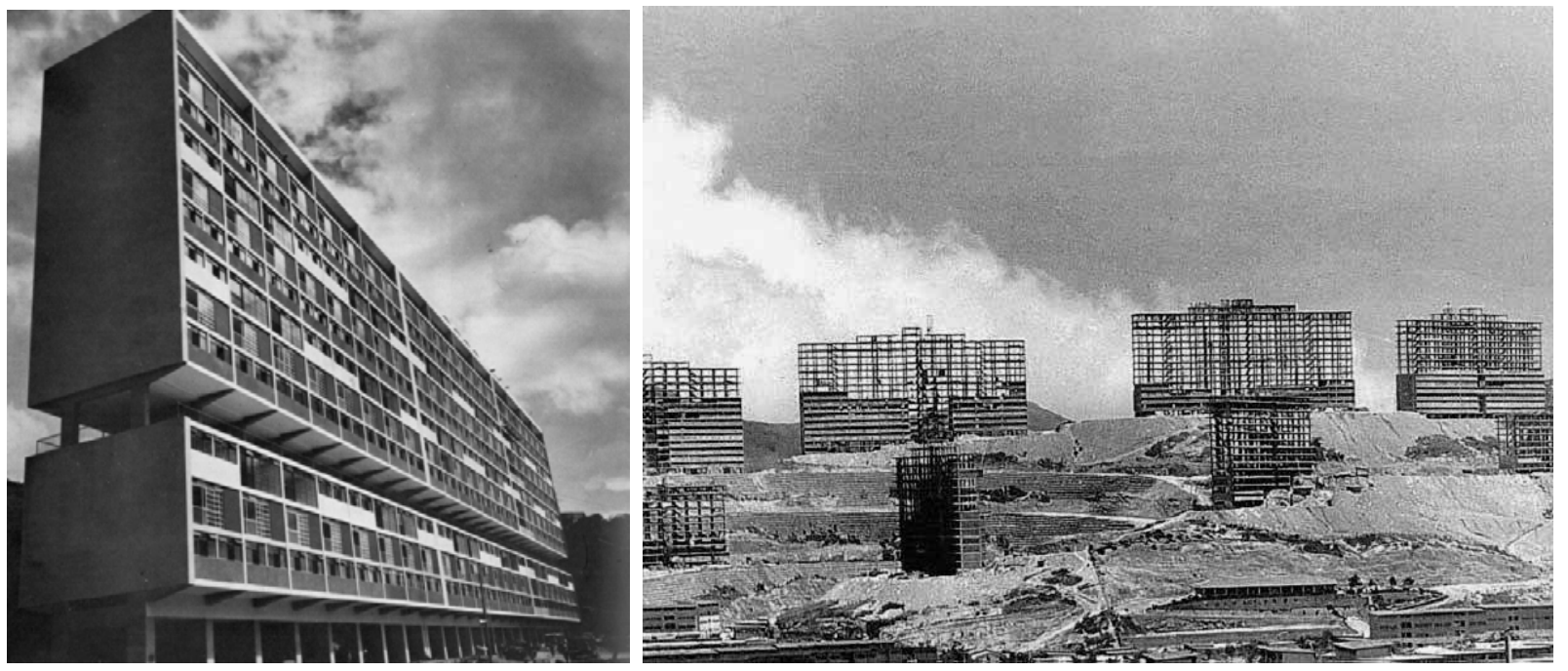

Fig. 11: Unidad de Vivienda Cerro Grande em El Valle, Banco Obrero. Arquiteto Guido Bermúdez, 1954. Fig. 12: Construção dos superblocos do conjunto 2 de diciembre. Arquiteto Carlos Raul Villanueva.
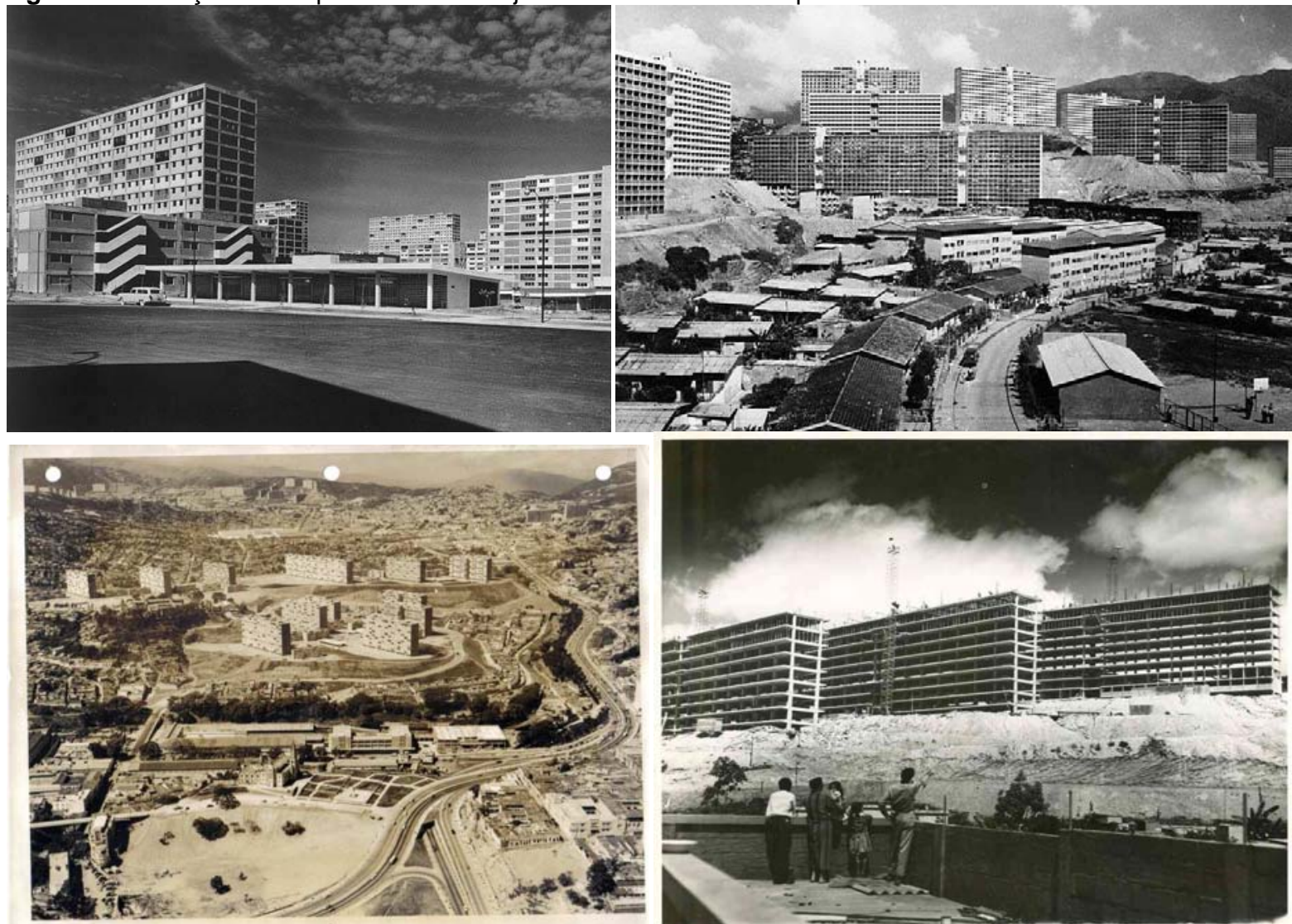

Fig. 13 a 16: Conjunto 2 de Diciembre. Arquiteto Carlos Raul Villanueva. 
O Plan Cerro Piloto se baseou nos censos nacionais de 1941 e 1950, que demonstou a existência de 53.000 ranchos, onde viviam 310.972 pessoas que representavam 38,53\% da população de Caracas na época (Meza, 2008). Em 1955, como proseguimento do programa Cerro Piloto foi lançado o Programa Presidencial para Erradicar la Vivienda Insalubre en Venezuela, por meio do qual bairros inteiros foram progressivamente demolidos para darem espaço aos projetos elaborados pelo Banco Obrero.

Segundo Beatriz Meza,

"diferentes programas rigen las acciones del Banco Obrero, desde el Plan Nacional de 1951 al Plan Cerro Piloto de 1954, al Programa de Erradicación de la Vivienda Insalubre de 1955 adelante. Ello evidencia la falta de una política habitacional claramente establecida por parte del Banco Obrero y del Poder Ejecutivo, lo cual lleva a la formulación de planes que se presentan teñidos de un carácter técnico-científico, pero cuya solidez es discutible, si cada cierto tiempo desde las mismas esferas gobernamentales son remplazados sin mayores problemas por nuevas propuestas".

Para conseguir atingir a meta proposta - pretendia construir, em 17 cidades do país, mais de 12.000 habitações, ou seja, uma quantidade equivalente a todas construídas pela instituição desde sua fundação em 1928 - o Banco Obrero se reorganiza em todos os niveles e amplia seu corpo de projetistas, como explica Manuel López:

"Bajo la dirección de Villanueva, un grupo de jóvenes arquitectos nacionales y extranjeros, y de estudiantes de arquitectura, funda el Taller de Arquitectura del Banco Obrero (TABO), del que saldrán los proyectos concretos para realizar el Plan y 'solucionar el problema de la vivienda en Venezuela'. Las nuevas urbanizaciones periféricas, dimensionadas en función de la jerarquía de sus servicios colectivos, se definen ahora como unidades vecinales, unidades cooperativas o comunidades" (López, 1996:71).

Em menos de 3 anos, de 1955 a 1957, depois de "alucinantes procesos constructivos ${ }^{11}$ y financieros" (López, 1996: 75) o presidente Pérez Jimenez inaugurava o conjunto 2 de dezembro, com mais de 9 mil apartamentos para alojar 60.000 pessoas em 26 superblocos, constituindo uma "experiencia sociológica y urbanística sin paralelo en América Latina" (López, 1996:75).

Com Villanueva à frente, a modernidade da arquitetura realizada no Taller de Arquitectura saltava aos olhos. Eram diretrizes do Taller "la construcción masiva, la simplificación de distribución, la eliminación de lo accesorio en el hogar a favor de lo esencial en su construcción, la educación de la familia mediante la demonstración práctica" (Banco Obrero, 1951 apud Maza, 2008: 38). O positivismo da política casava com o positivismo da arquitetura moderna, neste caso radicalizada na proposta da tábula rasa: de preferência a construção de conjuntos modernos sobre a terra arrasada, terraplanagem

\footnotetext{
${ }^{11}$ Os superblocos eram erguidos em 18 semanas.
} 
violenta, novos platôs que redefiniam os morros, sobre os escombros das antigas favelas, lugar do "ócio", "vício" e "promiscuidade".

Para alcançar as metas quantitativas prometidas, o modelo da "aristocrática" Unidad de Habitación Cerro Grande teve que ser revisto: "para adecuar a las realidades de la población marginal, desaparecerían los pilotis, los apartamentos duplex y sus loggias, los servicios colectivos y las torres de circulación vertical. De las ocho clases de apartamentos que se habían proyectado sólo se utilizarían tres, eso só, en un tiempo récord de construcción de seis meses". Assim foram construídos os superblocos pelo "eficiente empresariado nacional", que se "ofrecían gerenoros para autoeducación de los desalojados según los postulados del Nuevo Ideal Nacional" (López, 1993: 75).

Segundo Beatriz Meza Suinaga, "la poca o nula capacidad adquisitiva de la clase obrera no se considera. Así, muchas de las unidades residenciales destinadas a los grupos de menores recursos terminan en manos de la clase media (...). (Meza, 2008: 38)". Tal situação remete ao que ocorreu com o BNH no Brasil, sobretudo entre 1970-1974 quando, segundo Azevedo, a política adotada como resposta ao problema da inadimplência foi a de redução dos investimentos para as familias de baixa renda e aumento das aplicaçõs no chamado "mercado médio" (Azevedo, 1988: 113).

Desde que nasceu, o Banco Obrero, no desenrolar de sua história, insere progressivamente mais interesses "não declarados" dentro de seu escopo. Neste caso, a construção dos superblocos modernos no lugar das favelas próximas ao centro da cidade sugere dois interesses (para além do interesse primordial que deveria ser a provisão habitacional): 1. a imposição de um determinado modo de vida aos novos moradores urbanos, a partir da vontade de um general que expressamente dizia não acreditar nos "conucos", e 2. a retirada das favelas de áreas centrais em prol da valorização imobiliária e da defesa territorial do Palácio de Miraflores - nessa lógica, o Conjunto 2 de Deciembre funcionou como uma segunda fase do processo iniciado com a construção do conjunto El Silencio (erguido sobre terra arrasada de um bairro central dominado pela prostituição e tráfico de drogas).

A modernidade das realizações construídas escondia a barbárie das relações sociais - o aumento da desiguldade social, eliminação dos direitos políticos, aumento da favelização ao mesmo tempo em que remoções forçadas eram realizadas. A construção física da modernidade era realizada sobre uma base produtiva precária, com poucas intenções de alterar as características estruturais do atrasado setor da construção civil.

Pérez Jimenez caiu em 23 de Janeiro do ano de 1958, quando o conjunto 2 de diciembre seria rebatizado como 23 de Enero pelas famílias que decidiram aproveitar a revolta social para ocupar os edifícios que estavam em fase final de construção.

Já em 1959 foi realizada uma avaliação dos superblocos por meio do Programa de Evaluación de Superbloques del Banco Obrero (PESBO), cujo relatório final indicava uma situação social preocupante. 


\subsection{A democracia do Pacto de Punto Fijo}

Com a derrota do regime militar voltaram ao país os principais líderes políticos que se encontravam exilados no exterior. Os líderes do partido Acción Democrática defendiam a conformação de um pacto social que garantisse a consolidação do regime democrático, evitando medidas que poderiam ser consideradas sectárias e gerassem o risco de um novo golpe. O trauma do triênio democrático de 1945 a 1948 estava presente na conformação do pacto - que já havia se iniciado, antes mesmo da derrocada de Pérez Jimenez, em diálogos realizados no exterior entre os principais líderes políticos e a burguesia venezuelana.

Assim, os dois maiores partidos da época, a Acción Democrática e o social-cristão COPEI, estabeleceram um pacto de governabilidade que duraria 4 décadas - de 1958 a 1998, quando Hugo Chávez foi eleito. Este pacto, conhecido como Pacto de Punto Fijo ${ }^{12}$, ao mesmo tempo em que permitia a estabilidade do regime, evitava transformações estruturais na sociedade venezuelana.

A primeira reunião para a conformação do Pacto foi realizada em Nova York, com a presença de líderes da AD, Copei, assim como de uma terceira força, a Unión Republicana Democrática (URD), representados por Rafael Caldera, Rómulo Betancourt e Jóvilo Villalba respectivamente. Os dois primeiros governariam a Venezuela durante aproximadamente 15 anos. Nesta reunião foi decidida a exclusão do Partido Comunista da Venezuela (PCV), que era visto como uma ameaça à democracia (Mendes, 2012: 66).

Na contracorrente em relação ao contexto latinoamericano, o Pacto de Punto Fijo foi responsável pela consolidação de um regime democrático durante um momento histórico no qual ditaduras militares derrubavam governos eleitos por todo o território da América Latina. A conhecida exceção venezuelana, no entanto, é objeto de intensos debates, dentro dos quais se contesta a efetividade da democracia diante da manutenção de um sistema altamente repressor contra grupos políticos que não se adequavam ao Pacto.

\footnotetext{
12 "As minuciosas e longas conversas serviram para comprometer as organizações unitariamente em uma política nacional de grande alcance cujos dois polos podemos definir assim: a) segurança de que o processo eleitoral e os Poderes Públicos que dele surgirão respondam às pautas democráticas, da liberdade efetiva do sufrágio; b) garantia de que o processo eleitoral não somente evite a ruptura da frente unitária, mas a fortaleça mediante a prolongação da trégua política, a despersonalização do debate, a erradicação de violência interpartidária e a definição de normas que facilitem a formação do Governo e dos corpos deliberantes de modo que ambos agrupem equitativamente a todos os setores da sociedade venezuelana interessados na estabilidade da República como sistema popular de Governo (Pacto de Punto Fijo, citado por Plazo, 1999: 113 citado por Silva Mendes, 2012: 66)
} 


\begin{tabular}{|c|c|c|}
\hline Período & Presidente & Partido \\
\hline 1959-1964 & Rómulo Betancourt & $\mathrm{AD}$ \\
\hline 1964-1969 & Raúl Leoni & $\mathrm{AD}$ \\
\hline 1969-1974 & Rafael Caldera 1 & Copei \\
\hline 1974-1979 & Carlos Andrés Pérez 1 & $\mathrm{AD}$ \\
\hline 1979-1984 & Luis Herrera Campíns & Copei \\
\hline 1984-1989 & Jaime Lusinchi & $\mathrm{AD}$ \\
\hline 1989-1993 & Carlos André Pérez 2 & $\mathrm{AD}$ \\
\hline 1993-1994 & Ramón Velázquez & $\mathrm{AD}$ \\
\hline 1994-1998 & Rafael Caldera 2 & Copei \\
\hline
\end{tabular}

Os 40 anos de domínio dos dois partidos foram marcados, em um primeiro momento, pela consolidação da democracia na década de 1960, seguida pelo boom petroleiro da década de 1970 (época da chamada Venezuela Saudita). A segunda fase do pacto foi marcada, a partir de 1980, pela crise econômica, ajustes fiscais e revoltas populares (culminando no Caracazo em 1989), seguida pela Reforma do Estado na década de 1990 e tentativas de golpes de Estado (pelo então tentente coronel Hugo Chávez em 1992). A eleição de Chávez em 1998 significará o final deste ciclo.

Os anos 1960 e 1970

Diseño en Avance

Com a queda do general e o início de um novo período democrático, o Banco Obrero passou a atuar de forma diferenciada, começando por negar toda a experiência de construção massiva dos superblocos.

Uma inovação significativa foi a formação da Unidad de Diseño en Avance, instituição voltada à pesquisa tecnológica, decorrente do aprimoramento da experiência do Taller de Arquitectura del Banco Obrero. Esta Unidad seria o embrião do Instituto de Desarrollo Experimental de la Construcción (IDEC), sendo a primeira vez em que se pratica na Venezuela "un pensamiento lógico y racional sobre la técnica arquitectónica" (Cárdenas, 2008: 54).

" (...) la mecanización, la elevada productividad hombre/hora, los bajos costos, sob características asociadas al uso intensivo del capital invertido en el sector construcción, opción que debe ser confrontada al desempleo que presuntamente resolvería la diversificación socioproductiva de desarrollo. Ante estas realidades concretas, la utilización de considerable mano de obra en la construcción de vivienda va de la mano al estímulo a la construcción privada técnicamente artesanal". (Cárdenas, 2008: 57). 


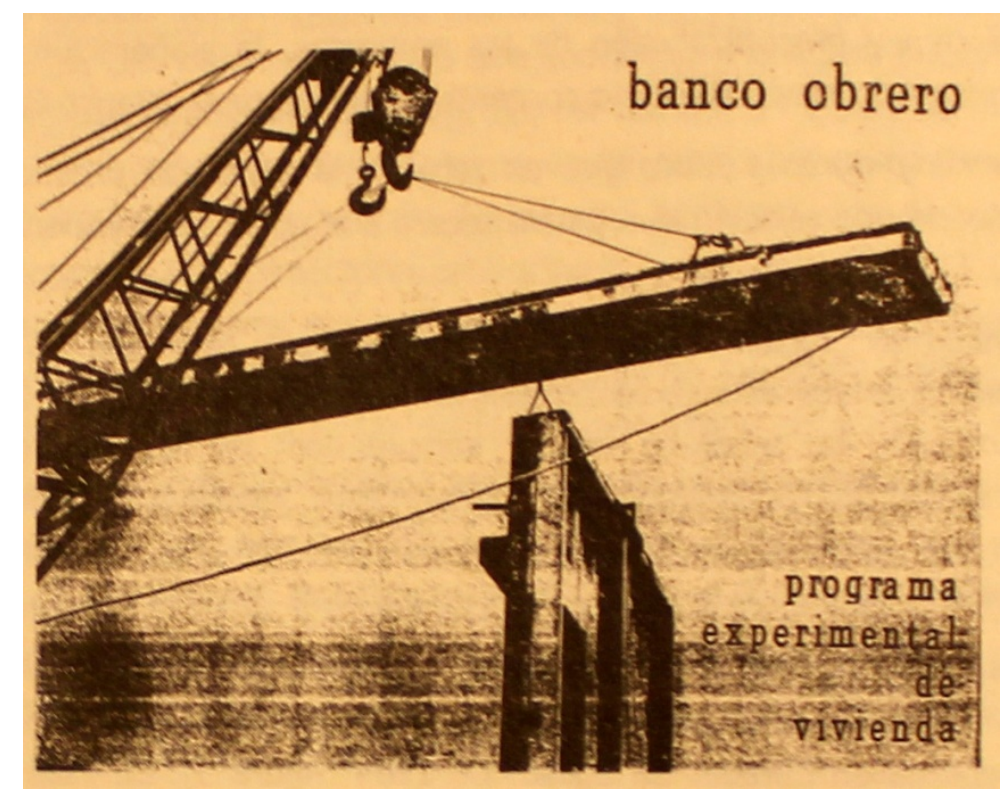

Fig. 17: Encarte do Programa Experimental de Vivienda. Fonte: Cárdenas, 2008.

As pesquisas da Unidad buscavam um novo enfoque na produção de edificações, que deveria partir da realidade da organização da construção e de sua forma de operação, segundo o diagnóstico do Banco Obrero, "...la demanda se mantiene separada del diseño, la demanda y el diseño separados del productor de componentes, y los tres separados de la construcción en sitio" (Lovera, 2004).

Segundo Alfonso Cárdenas,

"fue una experiencia destinada a incrementar la productividad de la institución a partir de la racionalización del sistema de la construcción masiva de la vivienda. Giró en torno al Programa Experimental de Vivienda, el ensayo constructivo a través del cual el Banco Obrero ocupó una posición de vanguardia dentro de la arquitectura de esos años (...)" (Cárdenas, 2008: 47).

Também na Unidad de Diseño en Avance a influência da experiência européia foi fundamental, por meio da participação do arquiteto Henrique Hernández, que trazia a experiência adquirida na Inglaterra. Como narra Alberto Lovera, quando o arquiteto Hernández regressa do exterior "relata en el Banco Obrero sus experiencias y lo que estaban haciendo los grupos ingleses que trabajaban en materia de desarrollo de sistemas construcctivos y de racionalización, en especial el Consortium of Local Authorities Special Programme (Clasp) $)^{13}$. Se presentan los sistemas constructivos del Clasp y su esquema organizativo 'como ejemplo correcto de desarrollo de la producción masiva de edificaciones para el sector público, dentro de enfoque de 'sistemas'" (Lovera, 2004).

\footnotetext{
13 "Se trata de una empresa pública de tecnología, creada por un grupo de municipalidades del Reino Unido, cuyo objetivo fundamental es el promover un sistema constructivo evolutivo(con diferentes versiones a lo largo del tiempo) y tecnología organizativa y de control administrativo y de costos para el programa de construcciones públicas (escuelas y otras edificaciones) de las municipalidades consorciadas". LOVERA, 2004.
} 
Além do arquiteto Hernández, também foi fundamental a contribuição do arquiteto Alfredo Cilento, que havia recebido uma bolsa de estudos das Nações Unidas e do Governo da Dinamarca para realizar para cursos neste país sobre industrialização da construção, ocasião em que conheceu e visitou os programas e plantas de pré-fabricação de habitação na Dinamarca, Suécia, Noruega, Alemanha, França e Inglaterra (Lovera, 2004). Ao regressar à Venezuela, Cilento preparou para o Banco Obrero o informe "Estudio de factibilidad para la instalación de la prefabricación en Venezuela".

Segundo Lovera, era fundamental que o Diseño en Avance estivesse à parte do Departamento Técnico do Banco Obrero, que atendia a problemas cotidianos, e impediria a realização de experimentações: "colocar a Diseño en Avance en la Oficina Técnica iba a desvituar su función, toda vez que no tendrían el ambiente adecuado para trabajar en investigación y desarrollo experimental porque serían sometidos a la presión de las urgencias de la atención de los programas cotidianos" (Lovera, 2004: 60). Portanto, o Diseño en Avance era mais uma unidade estratégica e menos uma unidade operativa.

A partir da preocupação com o aumento da produtividade, o Diseño en Avance buscava realizar pesquisas e experimentações que envolviam toda a cadeia da produção habitacional:

"Dicha preocupación llevaba lógicamente a explorar toda la cadena de la producción habitacional, desde la toma de decisiones y sus procesos administrativos, la forma de selección de las empresas hasta el proceso de producción mismo en todas sus etapas de programación, elaboración del proyecto y ejecución. El interés por los sistemas racionalizados e industrializados estaba asociado a esta preocupación, de la misma manera que a la búsqueda de nuevos métodos de diseño y una forma diferente de organizar la producción en todas sus fases". (Lovera, 2004: 69)

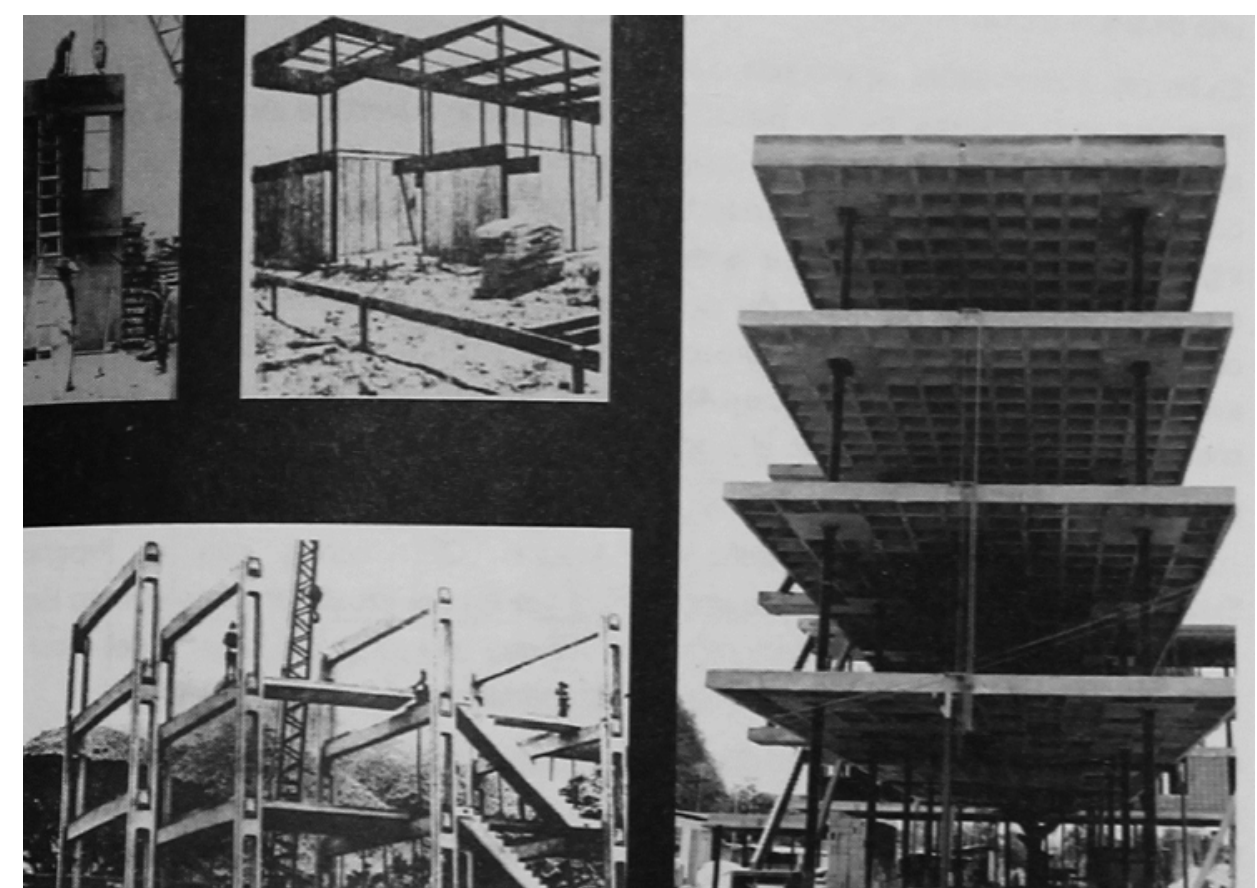

Fig. 18: Quatro Sistemas Construtivos do Programa Experimental de Vivienda Fonte: Cárdenas, 2008. 
As pesquisas e experimentações na construção habitacional pressupunha também repensar a linguagem arquitetônica e os métodos projetuais.

"Durante los primeros años de la década de los sesenta, Hernández, Martínez Olavarría, Cilento y quienes los siguen, aseguraban que dominar y ahuyentar el caos del sector construcción implicaba acrecentar la división entre trabajo proyectual y acontecer construcctivo. Exigía, luego, formalizar un lenguaje arquitectónico y un método de diseño mediante los cuales se tendieran los puentes entre esos dos momentos de la producción". (Cárdenas, 2008: 47)

A busca por soluções no campo fundamentalmente tecnológico se mostrou uma das limitações do Diseño en Avance, que acabava por desconsiderar a habitação como um produto inserido no aparato de produção, circulação e consumo da construção (Lovera, 2004). Segundo Cilento:

"Algunos de los componentes y sistemas diseñados se incorporaron rápidamente al aparato productivo, pero las expectativas en términos de calidad, velocidad de producción y precios, fueron anulados por el compartamiento posterior del mercado de la construcción. Los éxitos iniciales de un enfoque como éste, tenían que se anulados por una ley de la realidad económica que establece, que el precio de los productos lo fija el productor más ineficiente que encuentra mercado para su producción. El productor más eficiente obtiene entonces ventajas comparativas de costos, pero ubica sus precios a nivel del fijado por el mercado. Así sucedió con los sistemas constructivos desarrollados, los cuales a pesar de sus costos menores, ofertaban precios apenas algunos bolívares por debajo de los constructores tradicionales" (Cilento, 1980: 26-27 apud Lovera, 2004: 84).

Os êxitos e fracassos do Diseño en Avance não podem ser dissociados da conjuntura econômica e social da Venezuela dos anos 1960. As principais referências de industrialização que Hernández e Cilento traziam à Venezuela vinham de países altamente industrializados. Ao final, segundo Cárdenas, a Unidad de Diseño en Avance pressupunha um desenvolvimento nacional que não se realizou: "sin embargo, el modelo socioeconómico venezolano del desarrollo diversificado se agota con notable rapidez, particularmente en lo que concierne a la redistribución del ingreso, a la consiguiente ampliación del mercado interno, así como a un desarrollo industrial amplio y satisfatorio" (Cárdenas, 2008; 50).

A experiência do Diseño en Avance entra em fase de liquidação no final da década de 1960, quando mundanças no Banco Obrero levaram a um enfoque que privilegiava a construção tradicional. Segundo Lovera, foram nos momentos de recessão econômica que a questão da produtividade aparecia:

"Esta búsqueda de elevación de la productividad que estuvo presente en esta experiencia, contrasta con la que conoció la Venezuela que surgió tras el boom petrolero del año 1973 en adelante, y que sólo ha tomado nuevos bríos después de que la 
crisis económica iniciada a fines de la misma década de los setenta, que se hizo patente al inicio de los años ochenta, puso de manifiesto la importancia de la productividad para el desarrollo económico, y las enormes secuelas que ha dejado el descuido de una variable clase para el buen desempenõ de toda economía y sociedad" (Lovera, 2004: $69)$.

Os principais arquitetos do Diseño en Avance voltaram à Faculdade de Arquitetura da Universidad Central de Venezuela, onde estava em ebulição um intenso processo de renovação universitária.

A princípios dos anos 1980, por iniciativa conjunta do IDEC, do Sector de Estudios Urbanos e do l Instituto de Urbanismo da UCV, se organiza um ampla equipe de invetigação, que realiza o estudo mais completo sobre a indústria da construção na Venezuela. O projeto se chamava "Organización de la Industria de la Construcción en Venezuela. Componentes y Relaciones”, e tinha como objetivo aportar "nuevas e importantes luces sobre el funcionamiento del sector y particularmente de las empresas constructoras, sobre los procesos productivos, la circulación del capital en la construcción, y sobre las ganancias del empresario constructor".

Na década de 1960 se destacam alguns importantes avanços institucionais em matéria de política habitacional e urbana. Em 1961 foi criado o Sistema de Ahorro y Préstamo, que deu início à expansão do sistema mercantil de habitações e ao desenvolvimento de uma política de estímulos ao setor privado dirigida a setores não atendidos pela Banco Obrero. Também é importante destacar a criação em 1964 da Fundación para el Desarrollo de la Comunidad y Fomento Municipal (FUNDACOMUN), vinculado ao Ministerio de Obras Publicas e existente até hoje, para respaldar as atividades das comunidades organizadas e assessorar os governos locais. Tal iniciativa indica o início de um processo de descentralização que se aprofundaria na década de $1990^{14}$.

Também na década 1960 foi criada a Comisión para el Desarrollo Urbana y la Vivienda, em cujos informes se indicava a falta de uma política de terras para construção de habitações, recomendando a fixação de limites urbanos nas cidades, a criação de imposto progressivo para terrenos ociosos e o estabelecimento de contribuição sobre melhoras em razão de obras públicas. A Comissão também propunha leis municipais que permitissem ao município arrecadar a valorização gerada por mudanças do zoneamento. Segundo informações constantes no site da Fundación Escuela de Gerencia Social, "estos planteamientos fueron considerados como un intento de establecer una reforma urbana de corte socialista, lo que implicó su rechazo"15.

A política de aquisição de terra urbana se iniciou na década de 1970 com a criação do Fondo Nacional de Desarrollo Urbano (FONDUR), vinculado ao Ministerio de Obras Públicas, com o propósito de realizar um amplo programa de formação de reservas de terras para expansão urbana (HERNÁNDEZ, 2004: 337). Em 1975, com a idéia de proceder a descentralização, faz-se uma reforma institucional no Banco

\footnotetext{
${ }_{15}^{14}$ Fundación Escuela de Gerencia Social http://www.gerenciasocial.gob.ve.

15 idem.
} 
Obrero, que é então convertido no Instituto Nacional de la Vivienda (INAVI). A década de 1970 também foi marcada pelo aumento dos preços internacionais do petróleo a pelo boom da construção imobiliária.

O Ministerio de Obras Publicas, que até então exercia quase exclusivamente o poder de construir obras públicas no país (inclusive à revelia dos entes municipais), foi dividido em 3 instituições no ano de 1977 com a Ley Orgánica de la Administración Central, formando o Ministerio de Transporte y Comunicaciones, o Ministerio del Ambiente y los Recursos Naturales no Renovables e o Ministerio de Desarrollo Urbano (MINDUR).

A Ley de Política Habitacional e a redução da intervenção estatal nas décadas de 1980 e 1990.

"La década de 90 se está abriendo a nivel mundial con la presencia del modelo de la privatización como conductor del desarrollo económico. Pareciera que el sector público reducirá su tradicional rol de empresario directo, al constatarse la incorporación progresiva del sector privado en variados campos de la economía que venían siendo atendidos exclusiva o mayoritariamente por el sector público".

A constatação acima, de Oscar Camacho et. al. (1995: 161), escrita em artigo que compõe livro sobre as favelas venezuelanas, não tinha como objetivo a avaliação crítica da tendência mundial. Ao contrário, segundo os autores, era necessário readequar a política habitacional à nova realidade, seguindo as resoluções da ONU e Banco Mundial, segundo os quais

"los gobiernos han de servir de FACILITADORES en el sector de vivienda, abandonando su función de proveedores, dedicánsose más firmemente a facilitar la construcción de nuvas viviendas por el sector privado (tanto el estructurado como el no estructurado), para lo cual creará un ambiente regulador apropiado y garantizará la disponibilidad de financiamiento para los programas de vivienda". (Hábitat, 1988 apud Camacho et.al. Grifos no original)

A aprovação da Ley de Política Habitacional em setembro de 1989 se adequava a essa nova realidade. A nova diretriz da política habitacional, ao reduzir a intervenção direta do Estado na questão habitacional, se somava à tendência de diminuição do papel do Estado venezuelano em diversas áreas da economia. Dessa forma, a Venezuela seguia a tendência latino-americana da década de 1980-90 de liberalização da economia e redução da intervenção estatal nas questões sociais.

A década de 1980 foi marcada pela diminuição dos preços internacionais do petróleo, o que ocasionou um momento de grave recessão econômica na Venezuela, agravada pela dívida pública externa contraída durante os anos de bonança petroleira. É nesta década que são aprovadas as leis mais importantes de planejamento urbano vigentes no país como a Ley de Ordenación del Territorio de 1983 e a Ley de Ordenación del Territorio de 1987. 
A queda do preço do petróleo no mercado internacional no final da década de 1970 e início de 1980, somada aos vícios administrativos de duas décadas de pacto político, geraram um progressivo desequilíbrio da estrutura que sustentava o Pacto. A partir de então, as décadas de 1980 e 1990 serão marcadas pela instabilidade política e social na Venezuela.

A crise política e econômica se aprofundou a partir do conjunto de medidas macroeconômicas que o presidente Luís Herrera Campíns (1979-1984), tomara em 21 de fevereiro de 1983 - data que viria a ser conhecida como Viernes Negro. Este conjunto de medidas, que vinha como uma resposta drástica a uma situação econômica insustentável desde a década de 1970, incluía a desvalorização da moeda nacional, o bolívar, e a redução dos investimentos sociais, e teve impacto profundo e imediato no conjunto da sociedade venezuelana ${ }^{16}$.

No ano de 1984 o governo do presidente Jaime Lusinchi, de acordo com as demandas sociais e as promessas que fizera durante sua campanha em 1983 decretou a abertura de um processo de "reforma integral do Estado venezuelano", criando então a Comisión Presidencial para la Reforma del Estado, conhecida como COPRE (López Maya, 2005: 45). A proposta de reforma do Estado que se iniciava em 1984 buscava restabelecer a legimitidade das instituições republicanas e manter o modelo de democracia do Pacto (Mendes, 2012: 89).

Com a tendência à descentralização, em 1989 foi criada a Ley Orgánica de descentralización, delimitación y transferencia de competencia del Poder Público que segundo Henrique Hernández, "introduce cambios fundamentales en la estructura fundamental del Sector Vivienda: En lugar de generarse un proceso de desconcentración y descentralización, se mantienen los organismos centrales y la aparecen simultáneamente de aparatos paralelos en las Entidades Federales: Los INREVI y los IMUVI. Creándose además un nuevo organismo nacional: FUNDABARRIOS ${ }^{17 " ~(H e r n a ́ n d e z, ~ 2004: ~ 337) ~}$

A Ley de Política Habitacional vinha sendo discutida desde 1987 como resultado de um pacto entre COPEI e AD. Segundo Hernández, as principais expectativas da lei eram:

- um plano de habitação da largo prazo,

- garantir aporte fixo aos programas de habitação: 5\% do gasto público para habitação,

- o manejo dos recursos com maior autonomía da administração central,

- captação massiva de recursos financeiros a largo prazo para financiar programas de habitação para o setor da população de classe média,

- dar continuidade administrativa às atuações do Estado em matéria de habitação,

\footnotetext{
${ }^{16}$ Durante o governo Herrera Campíns ocorreram as primeiras eleições para os conselhos municipais, em 1979, fato que já indicava uma incipiente flexibilização do modelo centralista do puntofijismo.

${ }^{17} \mathrm{O}$ autor se refere à criação do Instituto Regional de Vivienda (INREVI) e Instituto Municipal de Vivienda (IMUVI) e à Fundación para el Desarrollo de Barrios (FUNDABARRIOS).
} 
- melhorar a atuação do setor público em resposta ao déficit habitacional.

O nível de intervenção do Estado na questão habitacional é, durante este período, tema de intenso debate. Alfredo Cilento em artigo de 1995 realiza crítica sobre a política de corte liberal que até o momento se realizava:

"la experiencia de los últimos 15 años nos indica que es necesario un radical cambio en las políticas dirigidas a la vivienda y al desarrollo urbano (o a los asentamientos humanos). Todas las políticas, incluyendo las que se derivan de la reciente Ley de Política Habitacional (LPH), se han basado en un enfoque 'financiero' del problema. Todo se reduce a obtener fondos presupuestarios o de ahorro, indexar los pecios de venta al salario mínimo oficial y otogar préstamos de largo plazo, ferozmente subsidiados". (Cilento, 1995: 151)

Alberto Lovera, em artigo escrito durante a vigência da Ley, em 1995, dizia que a sociedade estava "frente a una política sistemática de expoliación y dilapidación de la fuerza de trabajo". Isso ocorria também na política habitacional: "a la crisis crónica de los organismos encargados de la política habitacional de Estado, en particular del Instituto Nacional de la Vivienda (INAVI), se le ha sumado una orientación que privilegia antes que la política de vivienda una política dirigida a estimular la industria de la construcción, no es otra la tendencia dominante de la Ley de Política Habitacional, al menos que se se haga realidad el Programa Nacional de Asistencia Técnica que prevé dicha ley para la construcción y mejoramiento de viviendas de los sectores de más bajos ingresos". (Lovera, 1995: 180. Grifos próprios)

Nas palavras de Lovera, a habitação deveria ser uma das "áreas inescapáveis da ação estatal".

"El Estado, bien por la incompetencia de sus organismos o por la orientación dominante de la política estatal, ha venido abandonando su papel activo y orientador de la política habitacional, convirtiendo crecientemente a sus entes en meros colocadores de recursos, dejando en las empresas promotoras y constructoras y en la banca hipotecaria la verdadera definición de lo que se realizará en lo que a vivienda nueva se requiere. También aquí se ha impuesto la privatización como panacea, cuando en realidad lo que se demuestra es la falta de voluntad política para acometer la reestructuración y reforma del Estado en áreas inescapables de la acción estatal". (Lovera, 1995: 180)

Cilento, ao mesmo tempo em que se opunha ao enfoque basicamente financeiro da política habitacional, criticava o que chamava de "paradigma provedor" do Estado (Cilento, 1999: 31). Como alternativa, defendia o "desarrollo progresivo", que vincula à família ou à comunidade a responsabilidade por parte da provisão da habitação. As idéias do arquiteto inglês Jonh Turner são utilizadas no argumento destas posições, assim como os princípios defendidos no encontro da ONU Habitat II. Cilento explana essa posição nos seguintes termos: 
"(el Estado) apoya y facilita el esfuerzo que la gente realiza para proveerse de un hábitat adecuado y de una vivienda según sus necesidades cambiantes e sus deseos de progreso; y que favorece abiertamente la gestión de autoprodutores de vivienda individuales y colectivos: familias y organizaciones comunitarias de viviendas (OCVs). No se trata del modelo del Estado facilitador que muchos sectores políticos y económicos han interpretado como la cesión al sector privado empresarial, dentro de un modelo de economía de mercado salvaje, de todas las facilidades para terminar de transformar toda la producción de espacio construido en una simples mercancía más, transable según (no tan) ciegas leyes del mercado. La idea de una 'estrategia facilitadora, fue planteada por las Naciones Unidas como estrategia global de vivienda, en términos de movilizar todo el potencial de recursos de todos los actores envueltos en el proceso de producción y mejoramiento del hábitat; pero en el entendido que la decisión final de cómo alojarse, debe ser propia de la gente concernida". (Cilento,1999: 93).

É interessante comparar a afirmação de Cilento à opinião do atual ministro de habitação Ricardo Molina no Informe y Cuenta 2011, que caracteriza as Organizaciones Comunitarias de Vivienda (OCV) como uma "figura creada por el neoliberalismo para que los gobiernos no asumieran su responsabilidad ante el problema de la vivienda".

O debate em torno do nível de ação estatal girava em torno de basicamente três possibilidades: o enfoque puramente financeiro, o paradigma provedor, e aquela que era considerada a alternativa diante dos extremos, o "desarrollo progresivo".

A defesa pela habitação progressivamente construída pelo próprio morador vinha no sentido de negar a construção massiva da época dos superblocos, criticada pela forma autoritária como foi implantada, ao mesmo tempo em que se encaixava na cultura da autoconstrução individual e coletiva das favelas.

Leandro Quintana, presidente do Inavi nos anos 1979-1980, em artigo publicado em 2008, lamentava que os conjuntos habitacionais de crescimento progressivo não foram levados adiante. Segundo Quintana, em 1975 foram viabilizadas 100 mil "soluções habitacionais" em um ano, quantidade que, "de haberse continuado aplicando, en 1990 se hubiese logrado eliminar el déficit habitacional que existía en el país" (Quintana, 2008: 63). Mas soa estranho o discurso de Quintana quando este chega a lamentar o estabelecimento de padrões mínimos de habitabilidade: "Lamentablemente, estos programas fueron detenidos al producirse el cambio de gobierno por instrucción presidencial número 12, estableciendo como áreas mínimas para las viviendas a ser construidas entre 50 y $88 \mathrm{~m} 2$, quizás debido al auge petrolero, y se regresó a las viviendas instantáneas, costosas, reduciéndose la producción de las mismas y generándose las viviendas frías" (Quintana, 2008: 63).

Afinal, as famílias pobres das cidades venezuelanas não decepcionavam quanto à capacidade de ampliar mais e mais seu sobre-trabalho, como nota o próprio Quintana: "a pesar de no haberse otorgado créditos 
para materiales, ni organizado a la población, como posteriormente se realizó, las famílias, a través de la autogestión, concluyeron la mayorías de las unidades en pocos años". No artigo de 2008 o autor se diz satisfeito pela volta da idéia nos dias de hoje: "el sector privado actualmente plantea las 'viviendas semilla', lo cual me agrada escuchar (...)"18.

Se trata da defesa pela implementação na Venezuela das receitas "sugeridas" pelo Banco Mundial. Segundo Pedro Arantes, em estudo sobre as políticas do Banco Mundial para as cidades, "para essa população informalizada e parcialmente estagnada, mais uma vez se recomendam políticas de self-help, emolduradas agora pela retórica da 'solidariedade' e apoiadas por ONGs" (Arantes, 2006: 68). No caso da Venezuela, o início do reconhecimento das favelas por parte dos acadêmicos e gestores se deu por meio de diversos estudos (desde a antropologia até a arquitetura) sobre a construção progressiva das casas, na qual a solidaridade entre os vizinhos se mostrava como parte da cultura construtiva. Tais conclusões se encaixavam nos conselhos de self-help dos organismos internacionais, motivo pelo qual o termo autogestão aparece em inúmeros artigos da época - artigos escritos, porém, por gestores e acadêmicos. Atualmente, o termo autogestão na Venezuela é utilizado pelos próprios trabalhadores, que fazem parte do Movimiento de Pobladoras y Pobladores, e seu significado difere radicalmente daquele utilizado nos anos 1970-80.

Dos superblocos modernos ao loteamento com casa embrião, o Estado reduziu drasticamente sua intervenção direta nas diversas esferas da questão habitacional. Segundo José Rafael Velásquez, que dirigiu o INAVI de 1990 e 1993, "la decisión de apoyarmos en el sector privado constructor y financiero para la producción de viviendas y parcelas con servicios básicos y para la recaudación de las mensualidades, justificaron el inicio de un proceso de disminuición del tamaño del Insituto" (Velásquez, 2008: 74). Segundo Velásquez, em sua gestão a quantidade de trabalhadores do Instituto foi reduzida de 7.500 para 2.000 .

Antes de presidir o INAVI, Velásquez exerceu o cargo de chefe da División de Localización y Evaluación de Inmuebles de la Gerencia de Tierras do Fondur, na qual propôs "transformar al Fondo en un verdadero banco de tierras proactivo que iniciara un programa masivo de adquisición y habilitación de terrenos (...) el razonamiento consistía en que Fondur se beneficiaría de la plusvalía que esos terrenos obtendrían, gracias a la decisión de su organismo de adscripción, Mindur, de asignarles uso urbano habitacional." A Junta Administrativa do Fondur rachaçou a idéia, sob o argumento de que o "Fondur no había sido exitoso en las adquisiciones previas y no querían tomar nuevos riesgos".

Velásquez relata que

"La conclusión más importante consistió en que por primera vez el Estado venezolano reconoció su incapacidad financiera para resolver el problema habitacional de todas las famílias de bajos ingresos a través de soluciones tradicionales y tomó la decisión de

\footnotetext{
${ }^{18}$ Ao que tudo indica se trata do que, no Brasil, nomeia-se "casa embrião".
} 
iniciar un programa nacional de construcción de parcelas con servicios básicos que bautizó con la denominación de 'Programa de Habitación Progresiva'(PHP)".

As tais Parcelas con Servicios são os Lotes Urbanizados, ou nos termos nativos do Banco Mundial, Sites and Services (BNH, 1978). Na literatura da época, é frequente desaparecer o termo vivienda, agora substituído por "soluciones habitacionales"; era necessário criar uma nova expressão, uma vez que o embrião não dotava do mínimo necessário para mercer o nome de vivienda - se o termo remete ao lugar do "vivir", cabe-se perguntar o que ocorre quando o próprio termo é inviabilizado: como se vive em algo que não é mais uma vivienda?

A receita dos organismos internacionais, no entanto, não foi integralmente implentada na Venezuela ${ }^{19}$. Os motivos para tal acontecimento demandam maior profundidade de pesquisa. Quintana fornece uma pista: "quizás debido al auge petrolero".

De qualquer forma, a idéia moderna de um Estado construtor de conjuntos habitacionais com padrões até então universais de urbanização fora deixada de lado, enquanto a lógica do Banco Mundial, se não implementada integralmente, passava a incidir no pensamento sobre a política habitacional. Nos termos de Pedro Arantes, "a nova matriz urbanística formulada pelo Banco Mundial adota um ponto de partida novo, e mais pragmático: as necessidades mínimas não ditam mais o modelo de urbanização, e sim as possibilidades financeiras dos pobres urbanos" (Arantes, 2006: 64).

\section{Uma tragi-comédia de desacertos}

"Os governos e os grupos no poder enfrentam problemas reais, particulares $e$ determinados, de cuja solução depende a sua possibilidade de manter-se enquanto poder. Porém, o caráter particular e não universal, desses problemas reais, exige que a sua verdadeira natureza seja transfigurada para que possam assumir um significado compatível com a vontade popular. Em síntese, é este o processo pelo qual a ideologia mascara os problemas do real e os substitue pelos falsos problemas. Isto é, formulam-se problemas que não se pretende, não se espera e nem seria possível resolver, para legitimar o poder e para justificar medidas destinadas a satisfazer outros propósitos".

Gabriel Bolaffi

\footnotetext{
19 Mas largamente implantada em outros países da América Latina. No Brasil da década de 1980 e 1990 sequer podemos indicar uma política habitacional consistente em nível federal. Na Argentina, segundo María Cristina Cravino, "el surgimiento de nuevas reivindicaciones, como la de los 'asentamientos', que iniciaron a omienzos de los años 80 (...); el fracaso de las políticas 'llave en mano' (...); la profunda reforma del Estado que se acentuó a partir de 1989 (...) permitió la venta de tierras ociosas, dentro de la lógica de las privatizaciones (...); las nuevas orientaciones de las políticas sociales que propugnan acciones focalizadas hacia los sectores de mayores necesidades, junto con las propuestas de los organismos financieros internacionales en política habitacional que portulan que el Estado debía ofrecer distintas 'soluciones habitacionales' flexibles y progresivas, consistentes en acciones parciales (...)." [Grifos no original] - CRAVINO, María Cristina. Entre el arraigo y el desalojo. La Villa 31 de Retiro. Derecho a la ciudad, capital inmobiliario y gestion urbana. - 1 a ed. - Los Polvorines: Universidad Nacional de General Sarmiento, 2009 apud Lazarini, 2014.
} 
Ao investigar a história da política habitacional na Venezuela se descortina a história da construção da habitação como um falso problema. Utilizando as palavras que Gabriel Bollafi (1976) utiliza para falar da política habitacional do BNH, emerge a história de uma "tragi-comédia de desacertos" - ainda pior que o caso brasileiro, dada a situação dramática das cidades venezuelanas en comparação ao poder econômico que o Banco Obrero alcançou em diversos momentos históricos.

A história da política habitacional na Venezuela oferece um cardápio de soluções a problemas não declarados, mal ocultados sob o discurso oficial do problema habitacional:

a. o direcionamento do fluxo de recursos advindos da renda petroleira para setores específicos ligados ao setor imobiliário e à construção civil,

b. o controle político contra rebeliões (seja em 1928, para conter a rebelião liderada, entre outros, por Rómulo Bettancourt, seja em 1959 pelo próprio Bettancourt para conter rebeliões contra seu governo),

c. o controle da classe trabalhadora e a imposição autoritária de determinado modo de vida urbano (construção dos superblocos, remoção dos resquícios rurais dos chamados ranchos, e a intervenção higienista em El Silencio),

d. a disputa pela poder, por meio da manipulação da habitação como dividendo eleitoral (no caso da sociedade rentista da Venezuela o clientelismo é elemento fundamental na repartição do poder),

Quais foram, por exemplo, as consequências da política de formação de banco de terras pelo Estado venezualano? A julgar pela situação das cidades, onde $50 \%$ da população vive em favelas, não houve impacto significativo. Mas a julgar pela corrupção estrutural que forma o Estado venezuelano, presumese que resultados não declarados tenham sido alcançados.

Diversos motivos justificariam o desenvolvimento de uma política habitacional bem sucedida: a existência do Banco Obrero desde 1928, os recursos financeiros adivindos do petróleo, e a característica do Estado venezuelano que é, historicamente, um Estado forte. A realidade das cidades demonstra que nada disso foi suficiente. Pelo contrário.

\section{A cidade em extremos}

Chama atenção, em diversas grandes cidades da Venezuela, o contraste entre os extremos favela-cidade formal, enquanto são raros os loteamentos periférios com autoconstrução, como os que predominam nas grandes cidades brasileiras. A mal sucedida implementação da receita neoliberal dos lotes urbanizados talvez explique em parte o fenômeno. No entanto, não explica porque a urbanização pelo setor privado na Venezuela não se realizou via loteamentos urbanos periféricos, a exemplo do que ocorreu nas cidades brasileiras com base na lei federal 6766/1979. Na Venezuela, a lei que facilitava à iniciativa privada a 
realização de loteamentos foi aprovada apenas no ano de 1987. Segundo a Ley de Orgánica de Ordenación Urbanística, em seu artigo 84,

"Para iniciar la construcción de una edificación bastará que el propietario o su representante se dirija por escrito al respectivo Municipio a fin de notificar su intención de comenzar la obra. Se acompañará a esta notificación el proyecto correspondiente, la certificación de la capacidad de suministro de los correspondientes servicios públicos provistos por el ente respectivo, los comprobantes de pago de impuestos municipales y los demás documentos que señalen las ordenanzas".

Segundo Velásquez, antes da aprovação desta lei, "los profesionales tenían que esperar a que otros profesionales, a veces con menor formación profesional o académica, les aprobaran sus planteamientos" (Velásquez, 2008: 71).

Conclui-se que, antes de 1987, a iniciativa privada dependia da contratação pelo poder público para a construção de lotes urbanizados, ou quando fazia por iniciativa própria acabava à mercê do julgamento de profissionais do poder público que, ao que tudo indica, não possibilitavam a agilidade que o setor privado demandava: "piensen por un momento si nuestros abogados o nuestros médicos tuvieran que pedir permiso a otos profesionalres del ramo para poder representarnos o curarnos" (Velásquez, 2008: 71). A agilização dos trâmites para o setor privado se expressa no artigo 85 da lei: "los organismos municipales dispondrán de un plazo de treinta (30) días continuos, en el caso de edificaciones (o de noventa (90) días continuos, en el caso de urbanizaciones, para constatar únicamente que el proyecto presentado se ajusta a las variables urbanas fundamentales establecidas en esta Ley".

No entanto, em 1987 o acelerado processo de urbanização já havia ocorrido. Uma hipótese é que, sem que o poder público lograsse construir a quantidade necessária de habitações, e sem que a iniciativa privada o fizesse massivamente por meio de lotes urbanizados, deu-se a formação de uma estrutura urbana marcada pelo contraste violento entre a favela (autoconstrução e autourbanização), e a cidade formalmente construída (dentro dos parâmetros legais, com a participação de empresas na construção da habitação e da infra-estrutura).

Tal realidade indica um processo histórico das décadas de 1970-80 no qual não se permitiu o avanço "ágil" da iniciativa privada, mas tampouco se viabilizaram soluções pelo poder público. Neste ponto, caberia aprofundar a investigação sobre as formas não oficiais de participação do poder público: "a pesar de negar la existencia de los barrios, los políticos y/o funcionarios dan materiales para su construcción. Los niegan pero los fomentan. (Bolívar, 1996: 74)"

Essa realidade traz consquências importantes. Entre a favela e o loteamento periférico com autoconstrução há uma diferença significativa: a habitação pode ser resolvida de forma individual por meio da auto-construção familiar, enquanto a infra-estrutura só pode ser resolvida em um conjunto mais amplo - em relação ao saneamento, por exemplo, a luta pressupõe todo o conjunto de famílias inseridas dentro 
da bacia hidrográfica. A auto-contrução pode ser familiar, e comunitária apenas em momentos específicos (como a laje), enquanto a auto-urbanização é necessariamente coletiva, seja na realização das obras, seja na reivindicação.

Uma moradora de um barrio, em entrevista a Enrique Torres, fala sobre a auto-urbanização como justificativa pelo direito à posse: "derecho que tenemos la gente de las barriadas a un título de tierra, porque quien le dio valor a esas tierra fue la gente que construyó ahí, antes eso era monte y culebra, montaña, quien le puso urbanismo a esas tierras, quien metió las aguas negras, aguas limpias, luz, teléfono, vías fueron las comunidades, era justo que a nosotros nos dieran nuestro título de tierra por nuestras viviendas".

\subsection{Revolta e luta pelo Reconhecimento das Favelas.}

"Historicamente, violência e convulsão civil são mais comuns na cidade do que no campo. Frustrações que se acumulem nos pobres urbanos são rapidamente exploradas por extremistas políticos. Se as cidades não começarem a tratar da pobreza de forma mais construtiva, a pobreza poderá igualmente começar a tratar as cidades de forma mais destrutiva."

Robert McNamara

As favelas de Caracas escancaram o resultado de um processo histórico que não tratou a pobreza urbana da forma como Robert McNamara aconselhara. O temor do ex-secretário de Defesa dos EUA na guerra do Vietnã e então presidente do Banco Mundial, tinha na Venezuela grandes possibilidades de se tornar realidade ${ }^{20}$.

O acontecimento que mudou radicalmente os rumos da história política venezuelana ocorreu em 27 de fevereiro de 1989. Nesta data uma revolta popular de magnitude sem precedentes tomou a capital Caracas e todas as grandes cidades do país. Conhecido como Caracazo, a revolta durou cinco dias, e teve como saldo mais de 400 mortos.

Onze dias antes, o presidente Carlos Andrés Pérez havia anunciado um pacote econômico que atendia às exigências que o Fundo Monetário Internacional (FMI) colocara para a concessão de empréstimo de US\$ 4,5 bilhões à Venezuela.

Até o estampido da revolta, havia na Venezuela dos anos 80 a crença generalizada de que os venezuelanos eram o povo menos mobilizado da América Latina. Segundo López Maya, "se argumentaba que su sólida democracia, aceitada por la renta petrolera del Estado, había permitido

\footnotetext{
${ }^{20}$ Com um truque retórico, McNamara designa aos pobres o papel de agentes destrutivos da cidade; não seria a própria sociedade desigual (e sua forma cidade excludente) o elemento destrutivo e os pobres as principais vítimas da destruição?
} 
establecer y consolidar canales de mediación y representación eficientes que conjuraban el conflicto social pronunciado y/o violento" (López Maya, 2005: 85). Para Fernando Coronil a revolta do Caracazo foi a "mayor y la más violamentamente reprimida de las que se han realizado contra un conjunto de medidas de austeridad en toda la historia latinoamericana", e "después de 30 años de estabilidad gracias a los ingresos petroleros y el control de los sectores populares a través de los partidos, creían que el pueblo era incapaz de realizar acciones independientes". (Coronil, 2013: 455).

Com o aumento do preço da gasolina, as empresas de ônibus aumentaram em 100\% o valor da passagem. Na manhã do dia 27 de fevereiro, nas cidades periféricas da Grande Caracas, como Guarenas, Guatire e Litoral Vargas, assim como nos terminais de transporte coletivo suburbano da capital, se iniciaram as revoltas. Em Caracas se iniciou no Terminal Nuevo Circo, ponto de chegada dos ônibus suburbanos e próximo ao centro da cidade e à Universidad Central de Venezuela. Lá, desde às 6 da manhã estudantes do Instituto Politécnico Luis Caballero Mejías ocuparam o terminal interurbano, e se solidarizaram com os cobradores e trabalhadores do terminal (López Maya, 2005: 66), sentando no chão da via e impedindo a entrada e saída dos veículos. Quando já eram em maior número, uma multidão, liderada pelos estudantes, se moveram às importantes avenidas Lecuna e Bolívar, onde ergueram barricadas e bloquearam as principais vias arteriais da cidade. Uma nova multidão se aglomerou frente à UCV, chamando outros estudantes às ruas. A polícia já havia saído às ruas, mas tinha ordem de não reprimir. Ao final da tarde, um estudante da UCV foi morto à tiro de escopeta em frente ao Parque Central. Enquanto isso, as principais vias da cidade, incluindo as grandes vias expressas, estavam bloqueadas, e se iniciavam saques a lojas e caminhões. Se somaram à revolta os motoqueiros, levando gente, transmitindo informações, avisando se chegava a polícia. Ao cair da tarde, na hora de voltar às suas casas, os trabalhadores encontraram o Metrô fechado, sendo obrigados a caminhar pelas ruas, onde adquiriram consciência da magnitude do protesto, ao qual muitos se somaram (López Maya, 69). Isso foi o início de uma revolta que se espalharia por todo o país e duraria mais 3 dias.

A repressão ocorreu na mesma proporção da revolta. Foi emitida a ordem de toque de recolher, e uma repressão feroz avançou sobre toda a população, mas sobretudo contra os moradores dos barrios. No dia 1 de março, na escadaria Mesuca, no Petare, o exército disparou contra a multidão, assassinando mais de 20 pessoas. No 23 de Enero a situação era de terror, com a confrontação entre francoatiradores abrigados na cobertura dos superblocos e a polícia. No quarto dia da revolta, o presidente Carlos Andrés Pérez realizou um vôo sobre a cidade. Andrés Pérez estava tomado do mesmo temor de McNamara.

"A bordo de um helicópitero, o presidente da república, Carlos Andrés Pérez, cruzou ontem ao meio-dia o céu de Caracas para observar o saldo de três dias de batalha campal que se encenaram na área metropolitana. E, como declarou antes de embarcar no helicóptero, reiterou em sua chegada, meia hora depois: o que em princípio foi justo protesto popular pela crise econômica, transformou-se em alterações da ordem pública induzidas pelo que chamou de 'uma mesca de delinquência com traços fanstasmagóricos 
de subversãó. Enquanto o dizia, escutavam-se disparos desde a zona do 23 de Enero". (Jornal El Nacional 03/03/1989. apud Mendes, 2012: 106).

Nas palavras de Margarita López Maya, as noites dos dias 1 e 2 de março foram de pesadelo para os setores populares de Caracas (López Maya, 74).

"Incêndios, tiros, saques generalizados, feridos, mortos, bombas de gás lacrimogêneo e certa tolerância da polícia - que inclusive participou dos roubos massivos - deram à capital venezuelana um aspecto de cidade em guerra que ninguém teria imaginado 22 dias atrás, quando as agências internacionais só se referíam à transmissão do poder e classificavam este vale como 'centro da demoracia mundial'"21 . (Jornal El Nacional de 01/03/1989 apud Mendes, 2012).

Segundo Flávio da Silva Mendes, "de um dia para o outro, uma democracia exemplar se havia convertido numa feroz ditadura" (Mendes, 2012: 103).

O Caracazo marcou um momento de inflexão política profunda na Venezuela da segunda metade do século XX. Segundo Coronil,

"Estos acontecimientos marcaron una crisis del proyecto populista que había definido la relación entre pueblo y Estado desde 1936. Con el giro hacia las políticas de libre mercado y el desmantelamiento del desarrollismo populista, el discurso dominante comenzó a presentar al pueblo no ya como el virtuoso cimiento de la democracia, sino como una masa turbulenta y parásita a la que el Estado tenía que disciplinar y el mercado tornar productiva. Desde la perspectiva de los sectores populares, por otro lado, la élite se definía de manera creciente como un 'cogollo'corrupto, que había privatizado el Estado, saqueado la riqueza petrolera de la nación y atropellado al pueblo".

Nas palavras do historiador Ramón Velásquez, "naquele dia o povo saiu às ruas e não voltou mais pra casa" (López Maya, 2002: 16 apud Silva Mendes).

Omar Ovalles, em artigo intitulado "Explosión Social o Redes de Solidariedad? Un Enfoque Urbano del Problema", questiona a visão do Caracazo como uma explosão social totalmente espontânea. Segundo Ovalles (1978),

"Es evidente que hay una 'conducta de masas' en la cual el individuo se diluye en ella y se genera una especie de conciencia colectiva grupal, pero esto no exceptuaría que los liderazgos naturales y los grupos de agremiación a nivel de base no estuvieran allí

21 "Beirute em Caracas". Jornal El Nacional. 01/03/1989. apud Mendes, 2012: 103. 
presentes; unos refurezan a los otros y viceversa. La masa se reconoce a sus líderes y estos se apoyan en ella. No se trata de una 'estampida de caballos'".

De fato, a simultaneidade das ações na manhã do dia 29 de fevereiro indicam a existência, no mínimo, de redes de comunicação entre as favelas. Qual foi o papel dos tantos grupos de militantes, associações de vizinhos, lideranças religiosas de esquerda, partidos políticos, etc., no estampido da revolta?

A Teologia da Libertação estava presente nas favelas de Caracas. Esta ala da igreja tinha sua opinião expressada na Revista SIC, cujo editorial dois meses após o Caracazo expressava a seguinte posição:

"Não somos o que dizíamos que éramos e descobrir nosso verdadeiro rosto, o cair da máscara em pedaços, nos produziu incrível inquietação. Éramos uma sociedade classista sem luta de classes (ao menos sem que a luta chegasse a um grau problemático), porque o Estado com a renda petroleira atuava como um colchão social. [...] Apareceu o que os bispos latino-americanos reunidos em Medelín em 1968 classificaram como 'colonialismo interno'"22. (SIC, 1989: 148 apud Mendes, 2012: 112).

Três anos depois da revolta do Caracazo, foi organizada em 1991 a primeira Asamblea de Barrios de Caracas (ABC). Segundo Andrés Antillano (2005),

"la Asamblea de Barrios tuvo un aporte muy importante en definir algunos elementos de lo que podría ser un programa de luchas de los barrios de Caracas. El planteamiento de regularización de la tenencia de la tierra ocupada por los pobladores de las comunidades populares, las discusiones sobre la rehabilitación física de barrios, la propuesta de cogestión del servicio de agua de la ciudad, la demanda de autogobierno local, contribuyeron, entre otros, a enunciar y forjar el itinerario de lucha de los barrios caraqueño".

As ABC duraram até o ano de 1993 e chegaram a reunir dirigentes de mais de 200 favelas da capital (Antillano, 2005). Segundo Daniel Matos, Enrique Torres e Alejandro Fermín (2011: 63),

"de las discusiones realizadas en las $A B C$ surge un conjunto de propuestas que, siguiendo a Antillano (2005), podemos afirmar que contribuyeron a forjar e enunciar el itinerario de lucha de los barrios caraqueños. Las propuestas eran diversas y algunas de ellas fueron puestas en marcha, desde el año 2000, con el mandato del presidente Hugo Chávez Frías. Tal es el caso de los Comités de Tierra Urbana (CTU) y su lucha por la

\footnotetext{
${ }^{22}$ Referência à II Conferência Geral do Episcopado Latino-Americano: "A Igreja latino-americana julga dever orientar-se para a formação de comunidades nacionais, que refletem uma organização global, onde toda a população, porém, especialmente as classes populares, tenha, através de estruturas territoriais e funcionais, uma participação receptiva e ativa, criadora e decisiva, na construção de uma nova sociedade. Essas estruturas intermediárias entre a pessoa e o Estado devem ser organizadas livremente, sem uma intervenção indevida da autoridade ou de grupos dominantes, no seu desenvolvimento e na sua participação concreta na realização do bem comum total. Constituem a trama vital da sociedade. São também a expressão real da liberdade e da solidariedade dos cidadãos".
} 
regularización de la tierra urbana, las Mesas Técnicas de Água y su lucha por la cogestión del servicio de agua de la ciudad, los Consejos Comunales y la demanda por el autogobierno local, etcétera".

Segundo Roland Denis, a "Asamblea de Barrios" foi o "centro de inauguracion del poder social en el país y agente articulador de las luchas populares". Se tratava de um "espacio de debate y unidad de ación que finalmente elevó a un lugar hegemônico el discurso ideológico que se sustenta en la autonomia del poder popular y [...] como fuerza fundamental de legitimación de la nueva democracia” (Denis, 2001: 11 apud Bruce, 2013). Cada uma das grandes reuniões reuniam entre 700 e 800 dirigentes das comunidades barriales de Caracas. "Ahí [...] comenzó a escribirse un programa de lucha que [...] fue muy importante para ordenar lo que era, más adelante, el programa bolivariano" (Denis, 2009 apud Bruce, 2013).

Em 4 de fevereiro de 1992 Hugo Chávez tentou tomar o poder por meio de um golpe fracassado. Segundo Roland Denis, “a pesar del fracaso militar de la operación rebelde, de un momento a otro la autoestima subversiva creció en forma exponencial” (Denis, 2001: 31 apud Torres, 2011). Dentro desse contexto, as ABC começaram a se consolidar como um espaço fundamental na luta contra o modelo neoliberal imposto pelo governo durante toda a década de 1990: "La Asamblea de Barrios de Caracas, los movimientos pedagógicos de base, las redes culturales de base y de investigación-acción, el cooperativismo alternativo, la violencia liceísta y universitaria, los intentos de comunicacionales alternativos, las ofensivas proderechos humanos, el movimiento indígena y minero, la protesta de los jubilados, la misma interacción de agrupaciones e individuos que supuso la constante actividad conspirativa, son tan sólo algunos de los picos más simbólicos de movilización que al menos hasta el año 94 no en pocas oportunidades se tornó incontrolable” (Denis, 2001: 22 apud Torres, 2011).

Para Enrique Torres, "las ABC comienzan a asumir una posición clasista frente a las problemáticas fundamentales tanto dentro de las comunidades populares como del país. Comienzan a visualizarse como un espacio de construcción de poder. Se comienzan a discutir, como afirmaba Roland Denis, 'territorios concretos de poder'" (Torres, 2011: 38). As assembléias se diversificaram e se espalharamm a territórios diversos, onde as propostas eram elaboradas e levadas ao espaço comum das Asambleas de Barrios de Caracas. Se debatiam os mecanismos, formas e processos de construção do poder popular, assim como se discutiam e convocavamm os chamados cacerolazos e mobilizações contra as privatizações e os debates sobre o chamado de uma Assembléia Nacional Constituinte (Torres, 2011).

As ABC se articularam em torno da luta pela água e convocaram uma mobilização em direção à empresa pública Hidrocapital com o objetivo de paralizar o processo de privatização e exigir a participação da comunidade nas gestão dos serviços. Segundo Torres, "La movilización fue un detonante para paralizar la privatización de Hidrocapital y también abrió, producto de la llegada a la Alcaldía del Municipio Libertador de Aristóbulo Istúriz, la posibilidad de crear mecanismos de interlocución con el gobierno 
municipal concretándose así, la histórica propuesta de las Mesas Técnicas de Agua, los gobiernos parroquiales y el gobierno de la gente" (Torres, 201: 40).

A luta pela água, contra a privatização e pela participação na gestão será a semente de todo um processo político marcado pela mobilização popular de base, com a bandeira da participação direta em mecanismos de cogestão e autogestão. Os Comités de Tierras Urbanas serão resultado e impulsionadores desse processo, que irá desembocar nos Consejos Comunales - entidades territoriais de base que formam a estrutura da proposta do chamado Estado Comunal, a última grande bandeira de Chávez. 


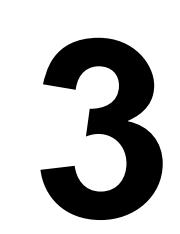

\section{Cidade e Habitação pós 1999}




\subsection{O processo de reconhecimento e os Comités de Tierras Urbanas}

Diante de tamanha pressão social entre meados da década de 1980 e 1990, o Estado buscou dar respostas por meio do aprofundamento das reformas políticas. Assim, ainda no ano de 1989 foram aprovadas leis fundamentais de reforma do Estado, entre as quais destacamos: Ley sobre Elección y Remoción de Gobernadores de Estado, Ley Orgánica de Descentralización, Delimitación y Transferencia de Competencias de Poder Público (LODDTC) e a Ley Orgánica de Régimen Municipal.

A lei que tratava dos governadores de Estado estabeleceu a eleição direta para governadores, que então eram designados pelo presidente da república. A lei orgânica de descentralização transferia ao nível regional competências até então atribuídas ao governo federal. A lei que tratava do regime municipal separou as funções do executivo e do legislativo, até então reunidas no Consejo Municipal. Ressalta-se que esta lei criou as parroquias e juntas parroquiales, com o objetivo de propiciar a descentralização administrativa no interior do território do município, reconhecendo as associações de vizinhos como atores locais (López Maya, 2006: 117). É curioso notar que as eleições diretas aos governos do Estado se institucionalizaram na Venezuela apenas nesse momento, a despeito da longeva democracia vigente desde o ano de 1958.

Nas palavras de Margartia López Maya, essas reformas atuaram como um oportuno "salva-vidas" do sistema político de então. A Reforma do Estado na Venezuela seguia o princípio da descentralização, também presente no processo de redemocratização brasileiro. Enquanto o Estado brasileiro realizava o processo constituinte após duas décadas de ditadura, na Venezuela a Reforma do Estado ocorria durante a grave crise institucional de uma democracia que já durava três décadas. Ambos processos, no entanto, pautavam a descentralização como forma de fortalecimento da democracia. Tanto na Venezuela como no Brasil as consequências deste processo são controversas: para além das questões institucionais de fortalecimento da democracia, a descentralização muitas vezes acabou por fortalecer o funcionamento de uma lógica neoliberal.

A Venezuela entrava na década de 1990 com uma nova base institucional e em meio a uma grave crise social, econômica e política. Estavam dadas as condições para a emergência de novas forças políticas e uma nova complexidade social, o que inclui a figura de Hugo Chávez, cuja primeira aparição pública fora na tentativa de tomada de poder por meio de um golpe de Estado em 1992.

Entre as novas forças políticas que emergiram nesta nova conjuntura se destacava o partido La Causa Radical, mais conhecido como La Causa R (LCR). A LCR, um partido pequeno na década de 1980, se tornou no início da década de 1990 a terceira força política do país, realizando experiências progressistas em prefeituras e governos do Estado.

A LCR ganhou as eleições na cidade de Puerto Ordaz em 1989, com Clemente Scotto, onde inovaria a partir da proposta de Mesas Técnicas e assembléias. Contrariando todas as expectativas, a LCR venceu as eleições na capital Caracas em 1992, com Aristóbulo Istúriz, que viria a realizar importantes práticas 
de democracia direta na capital baseados na partir da experiência de Puerto Ordaz (López Maya, 2011:19). Aristóbulo Istúriz é hoje governador do Estado de Anzoátegui e um dos mais importantes quadros do chavismo. Em 4 de dezembro de 1992 ocorreu a segunda tentativa de tomada de poder por meio de golpe de Estado liderado por Hugo Chávez. Poucos meses antes, integrantes das ABC e diversos militantes se reuniram na Plaza Caracas para defender a vitória de Istúriz que estava sendo contestada pela oposição. Nas palavras de Roland Denis: “la asamblea de barrios fue la que garantizó que ganara Aristóbulo. ¿Cómo garantiza? No es por los votos, porque los votos se los ganó él. Pero nosotros estuvimos tres días enteros en la Plaza Caracas en una especie de asonada para que se reconociera la victoria de Aristóbulo” (Entrevista a Torres, 2011),

Muitos dos princípios defendidos pelas forças políticas emergentes da nova conjuntura iriam reaparecer na proposta do candidato Chávez em 1998, e seriam consolidadas a partir da Constituição aprovada em 1999.

Hugo Chávez venceu as eleições de 1998 prometendo refundar o Estado e chamar a Constituinte. Em sua posse, com as mãos sobre a Constituição de 1961, dizia "jurar sobre essa moribunda Constituição". Eleito, Chávez convocou uma Assembléia Constituinte, e a nova Carta Magna foi aprovada em dezembro de 1999 sob Referendo Popular. Em seu preâmbulo, a Constitución de la República Bolivariana de Venezuela (CRBV) afirma que tem como fim "refundar la República para establecer una sociedad democrática, participativa y protagónica, multinétnica y pluricultural en un Estado de justicia, federal y descentralizado (...)". Além da permanência dos poderes Executivo, Legislativo e Judiciário foram instituídos o Poder Cidadão e o Eleitoral. O Poder Legislativo se tornou unicameral, estabelecendo a Assembléia Nacional.

Se por um lado o governo de Chávez indicava o fortalecimento da descentralização e da democracia participativa, por outro era criticado pela concentração de poderes em suas mãos. Segundo Villa (2005), "dentre as críticas à nova Constituição, destaca-se a excessiva concentração de poder nas mãos do presidente, que passou inclusive a ter o poder de legislar por meio da lei habilitante a respeito de qualquer matéria. Em finais do ano 2000, a Assembléia Nacional aprovou um pacote de 49 leis habilitantes" (grifo no original). Entre as leis habilitantes, as mais polêmicas eram a Lei de Terras e a Lei de Hidrocarbonetos ${ }^{23}$.

\footnotetext{
${ }^{23}$ Segundo Villa (2005), "o governo passou a exigir que o capital venezuelano tivesse maioria acionária nas parcerias com petroleiras estrangeiras atuantes no país, o que os defensores da liberalização do setor viram como retrocesso". Quanto ao território nacional, o novo governo apresentava a proposta da descentralizaçãodesconcentrada, tese defendida pelo então ministro de Planificación y Desarrollo Jorge Giordani. Segundo Contreras Nanteras (2003), "en palabras de sus principales portavoces, la política de descentralizacióndesconcentrada tiene como propósito fundamental aprovechar las potencialidades del país para lograr una distribución más equilibrada y sostenible de las actividades productivas, las inversiones y la población a lo largo del territorio nacional". A nova Constituição criou o Consejo Federal de Gobierno que, segundo a Exposição de Motivos da Assembléia Nacional Constituinte, terá como funções "planificar y coordinar horizontalmente las políticas y acciones para el desarrollo del proceso de descentralización y la administración del Fondo de Compensación Interterritorial destinado al financiamiento de inversiones públicas con el fin de promover el desarrollo equilibrado de las regiones de menor desarrollo relativo" (VENEZUELA, 2009).
} 
No decorrer das gestões chavistas, várias foram as estratégias de promover a participação direta da sociedade civil na gestão, planejamento e execução de políticas públicas, com destaque para as Missões Sociais $^{24}$. A mais conhecida, a Misión Barrio Adentro, implantou postos de saúde dentro das favelas por todo o país, realizando atendimento médico (médicos cubanos) com cunho preventivo. Segundo a PDVSA, "estas iniciativas contam com recursos extradordinários, sua coordenação é interintitucional e interministerial e um dos elementos fundamentais para seu planejamento, execução e acompanhamento é a participação ativa e protagônica das comunidades organizadas" ${ }^{25}$. No âmbito produtivo, o governo buscou incentivar a criação de cooperativas e Empresas de Produção Social (EPS) ${ }^{26}$, cujas produções estejam associadas às demandas da comunidade na qual se insere.

Em termos territoriais, se destacam a formação dos Comitês de Terras Urbanos (CTU’s) e das Mesas Técnicas de Água (MTA).

Miguel Lacabaña e Cecília Cariola (2005: 117) explicam que, com as mudanças institucionais, sobretudo após a Constituição Bolivariana de 1999 e a aprovação da Ley Orgánica para el Servicio de Agua Potable y Saneamiento (LOPSAPS) em 2001, houveram mudanças substanciais no Sistema de Agua Potable y Saneamiento (SAPS), que ampliou o serviço sob o critério de "equidad", incrementando o atendimento dos setores populares, e a "incorporación de la participación comunitária en la gestión del servicio y el desarrollo de una nueva cultura del agua". Segundo os autores, "una nueva cultura del agua en Venezuela se refiere a la participación comunitaria en la provisión y acceso al servicio, pero también a la racionalización de su uso y preservación, a la visión integrada de cuencas y de su ciclo completo, así como derechos humano y social".

O conceito de Mesas de Trabalho surgiu em Puerto Ordaz na gestão do partido LCR nos anos 1990, como um lugar de encontro de funcionários locais com suas comunidades com o objetivo de resolver problemas de maneira conjunta. As MTA podem ser compreendidas como um desenvolvimento dessas mesas de trabalho, especialmente para o tema da água, promovidas pelo prefeito de Caracas Aristóbulo Istúriz, do mesmo LCR, em sua gestão de 1993 a 1996 (Lópes Maya, 2011: 29).

Segundo Santiago Arconada (2006),

\footnotetext{
${ }^{24}$ Foram criadas mais de 20 missões sociais desde o início da década de 2000, que contemplam um amplo espectro da proteção social. Na tema educacional, foi criada a Misión Robinson I, destinada à alfabetização. Uma mostra contundente do impacto da missão foi a declaração em 2005, por parte da UNESCO, da Venezuela enquanto "Território Livre do Analfabetismo" pela UNESCO, Misión Robinson II, destinado à educação básica, Misión Ribas, e Misión Sucre, voltada aos estudos universitários.

${ }^{25}$ Retirado de www.pdvsa.com em novembro de 2012. A PDVSA, empresa estatal de petróleo, financia e inclusive gerencia grande parte das missões sociais.

${ }^{26} \mathrm{Em}$ discurso em seu programa semanal Alo Presidente, Chávez definiu da seguinte forma as EPS: "Empresas de Producción Social: son aquellas entidades económicas dedicadas a la producción de bienes o servicios, en las cuales el trabajo tiene significado propio, no alienado, auténtico; en las cuales no existe discriminación social en el trabajo y de ningún tipo de trabajo, no existen privilegios en el trabajo asociados a la posición jerárquica. Aquellas entidades económicas con igualdad sustantiva entre sus integrantes, basada en una planificación participativa y protagónica, y bajo régimen de propiedad estatal, propiedad colectiva o la combinación de ambas" (EL TROUDI, H., MONEDERO, J. C. , 2006: 91).
} 
"básicamente, lo que se le planteaba a todas las comunidades era los elementos básicos de un diagnóstico participativo. Se planteaba la necesidad de elaborar el censo de la comunidad, de comprender el problema que se tenía en términos de suministro, para lo cual fue planteado a la conveniencia de la realización de planos o croquis por parte de las mismas comunidades, experiencia ésta que fue tremendamente rica y mucho más profunda de lo que imaginamos en un principio, en la medida en que esta incorporación de las comunidades a los planos de la empresa hidrológica era una verdadera victoria política (...) Con este diagnóstico fue posible comenzar a comprender las implicaciones de la ausencia de planificación en la vida cotidiana de los barrios y de las zonas populares en las cuales se hacía ese trabajo".

A reunião de várias MTA de determinada região (parroquia ou bacia hidrográfica) formam um Consejo Comunitário de Agua (CCA), que se reúne a cada 15 dias com técnicos da empresa estatal. De fato, em termos de luta social, a água apresenta a interessante capacidade de ampliá-la à escala da bacia hidrográfica, território adequado para o planejamento hidrográfico. Além disso, ao trabalharem com a infraestrutura urbana, a participação social na questão da água propicia um importante aprendizado político junto às instituições. O fato da água ser um serviço em rede, que engloba a cidade em seu conjunto, amplia a discussão da comunidade ao urbano como um todo. O relato da engenheira Manuela Zerpa, entrevistada por Mato et. al. (2011), exemplifica esse processo:

"Los proyectos que se hagan, las propuestas que quiera desarrollar la comunidad no pueden estar fuera de lo que es el 'Plan Maestro', porque no van a tener efecto. (...) Se quiere solventar el problema en Las Casitas, pero hay otras comunidades que tienen la [misma] problemática. Entonces tienes que tener una visión de comunidad, no es solamente un sector. Las propuestas - por eso se les dice 'Plan Maestro' - engloban soluciones para varias comunidades cercanas que van a tener una solución con el desarrollo, con la construcción de propuestas".

Em visita a uma reunião na favela do Petare, na ocasião da conformação de uma MTA no setor José Felix Ribas, tivemos a oportunidade de presenciar a explicação de uma liderança comunitária sobre a necessidade de reunir todas as comunidades que viviam dentro da bacia hidrográfica, pois essa era a única forma de resolver o problema da água. A bacia hidrográfica em questão era o setor José Félix Ribas, onde habitam mais de 100 mil pessoas, e constitui uma das 4 partes que formam o complexo do Petare - considerada uma das maiores favelas do mundo. No início da intervenção, esta liderança, que também faz parte dos CTU, comparou a bacia hidrográfica do José Félix Ribas com a bacia em frente ao Petare, um bairro formal de classe média, onde segundo ela não há falta água em nenhum dia da semana. Naquele momento, a liderança acabara de ampliar a discussão da pequena comunidade à rede urbana como um todo, passando antes pela escala intermediária da bacia hidrográfica. 
O aprendizado político dentro de uma experiência em uma MTA se alimenta da amplitude de questões técnicas e políticas que acabam se desenvolvendo a partir da questão da água, conforme descrevem Lacabaña e Cariola (2005: 127):

"el proyecto constituye un paso fundamental para la comunidad ya que da una visión de futuro concreto y permite organizar la participación para lograrlo. Además, las MTA se encargan de cogestionar el financiamiento de los proyectos ante diversas instituciones y de regularizar el pago del agua, como una responsabilidad que la comunidad debe comprender y asumir. En este proceso se crean relaciones entre las comunidades y las instituciones que dan cuenta no solamente de un cambio en la gestión del servicio, sino también en la cultura ciudadana: el desarrollo de valores propios de la ciudadanía entre otros: la tolerancia, la tenacidad, la responsabilidad-, el aprendizaje de derechos y deberes, el encuentro de saberes técnico y popular".

Na opinião de Margarita López Maya, a contribuição da MTA, como conceito e como prática, à melhora da qualidade da democracia venezuela parece inquestionável (López Maya, 2011: 56). A autora lembra que a experiência inspirou outras inovações, como as mesas técnicas de gás, eletricidade, etc.

As experiências das MTA foram sem dúvida fundamentais para o desenvolvimento dos Comités de Tierras Urbanas. Ao tratar da questão da regularização fundiária, os CTU trazem à tona a questão do reconhecimento. Este é um tema especialmente destacado entre os militantes dos CTU, sendo expressado no título do artigo Lucha por Reconocimiento, de Andrés Antillano (2005), liderança que partipa dos CTU desde sua fundação. A consideração da coincidência dos termos com a obra de Axel Honnet (2003), também intitulada Luta por Reconhecimento, pode ser profícua, dado o interessante quadro conceitual fornecido pelo filósofo alemão para a interpretação dos conflitos e movimentos sociais na atualidade ${ }^{27}$.

O não reconhecimento da população moradora nos assentamentos precários se evidenciava na ausência destes nos mapas da cidade de Caracas. O nível de conflitividade desta situação pode ser compreendido quando tomamos em conta que mais de $50 \%$ da população da Venezuela vive em assentamentos precários (Cilento, 1996 em Antillano, 2005). Tratava-se, portanto, do não reconhecimento de metade da população do país ${ }^{28}$.

\footnotetext{
${ }^{27}$ Axel Honnet (2003), tido como o principal expoente da terceira geração da Escola de Frankfurt, a partir a teoria de reconhecimento de Hegel busca formular um quadro interpretativo dos conflitos sociais com base na luta pelo reconhecimento intersubjetivo, que se daria a partir da experiência de desrespeito. Segundo Salvadori (2011), essa luta ocorre "devido à experiência do desrespeito que se dá desde a luta pela posse da propriedade até à pretensão do indivíduo de ser reconhecido intersubjetivamente pela sua identidade. (...) As mudanças sociais podem ser explicadas por meio do desrespeito, gerador de conflitos sociais. Os conflitos surgem do desrespeito a qualquer uma das formas de reconhecimento, ou seja, de experiências morais decorrentes da violação de expectativas normativas. A identidade moral é formada por essas expectativas. Uma mobilização política somente ocorre quando o desrespeito expressa a visão de uma comunidade. Portanto, a lógica dos movimentos coletivos é a seguinte: desrespeito, luta por reconhecimento, e mudança social".
}

${ }^{28}$ Boaventura de Souza Santos nos lembra de que "a principal característica estrutural dos mapas reside em que, para desempenharem adequadamente as suas funções, têm invevitavelmente que distorcer a realidade". O autor se referia à necessidade intrínseca dos mapas de trabalhar com escala, projeção e simbolização, ou seja, 
Carmen Victoria, ex-moradora da favela Los Manolos e atual advogada do Campamento de Pioneros, relata a luta pelo reconhecimento das favelas de Caracas:

"Fíjate tu. Nosotros empezamos a hacer un censo. Primero de cuantas famílias éramos, cuales eran las expectativas, los grupos familiares, como estaban constituídos, donde estában, estudio socioeconómico y nos dimos cuenta a nivel de todo lo que era el município que los barrios no existían en los planes. Los Manolos es una excepción, pero normalmente salía 'Zona Verde'. Mentira, zonas eran de famílias, con esperanzas, con sueños, de lucha. Cuando nos dimos cuenta de esa situación buscamos la manera de que la misma alcadía se encargaba de sua trabajo como tal, pero pasado el tiempo nada había de concreto. En las reuniones que historicamente se hacen todos los jueves en los Comités de Tierras Urbanas, hasta la fecha es el grupo organizado en revolución que más tiempo tiene reuniendose, todos los jueves, religiosamente".

A Ley de Ordenación Urbanística (LOU), aprovada em 1987, reconhecia a existência dos assentamentos precários, denominados como "asentamientos no controlados", que poderiam ser objeto de planos especiais. No entanto, a lei não criava instrumentos que permitissem, na prática, a regularização dos assentamentos.

O ponto de inflexão na questão dos assentamentos precários foi o Decreto 1666, promulgado pelo presidente Hugo Chávez em fevereiro de 2002. O Decreto apresentava como objetivo "iniciar, con la participación protagónica de las comunidades organizadas, el proceso para regularizar la tenencia de las tierras urbanas ocupadas por barrios y urbanizaciones populares, procurando la debida coordinación interinstitucional". Também neste Decreto se intitucionalizaram os Comitês de Terras Urbanas $^{29}$. Segundo Alexis Villegas, “[...] Lo que caracteriza a los Comité de Tierras, es que venimos

distorções da realidade. Santos continua seu racicínio explicando que "a distorção da realidade que isso implica não significa automaticamente distorção da verdade, se os mecanismos de distorção da realidade forem conhecidos e puderem ser controlados". (SANTOS, 1988: 142, 143)

${ }^{29}$ Segundo o Decreto 1666, os CTU devem se organizar a fim de:

"a. Fomentar la participación de los miembros de la comunidad en el análisis y formulación de observaciones, propuestas, opiniones y comentarios sobre el Anteproyecto de Ley de Regularización de la Tenencia de la Tierra en los Asentamientos Urbanos Populares,

b. Recopilar información que facilite la realización del inventario de las viviendas y edificaciones que conforman los barrios y urbanizaciones populares; así como el levantamiento de planos provisionales, que definan los límites geográficos donde se asienta la comunidad, identificando el ordenamiento urbanístico espontáneo, natural e histórico e indicando el parcelamiento y sus usos, a los fines de su incorporación en el registro de asentamientos urbanos especiales;

c. Elaborar los listados de familias que integran la comunidad del barrio o urbanización, o sectores dentro de los mismos, a los fines de la suscripción de la Carta del Barrio, como instrumento de reconocimiento del barrio suscrito en forma colectiva por los vecinos.

d. Iniciar procesos de discusión a fin de definir y decidir las medidas que deben adoptarse en el barrio o urbaniación popular para mejorar el hábitat, y elevar dichas propuestas a la municipalidad u demás entes competentes, con el fin de contribuir en la formación, ejecución y control de las políticas públicas para la rehabilitación integral de los asentamientos urbanos, a partir de la regularización de la tenencia de la tierra". 
de una lucha de mucho tiempo en espacios diferentes y que el decreto 1.666, nos encontró, nos hizo encontrarnos"30.

Na Venezuela existem cerca de 7000 CTU's, sendo que cada Comitê representa uma poligonal com uma quantidade próxima a 200 famílias (Madera, 2010). Os Comitês são eleitos em assembléias públicas em sua comunidade, entendida como um território "não maior do que 200 famílias e que por sua origem, idiossincrasia, espaço geográfico, constitua uma unidade” (Antillano, 2006: 203), ou seja, um território limitado onde seja possível haver uma identificação enquanto comunidade.

Andrés Antillano explica que a participação no processo de regularização urbana integral conformaram a base para uma "nova forma de poder", construída sobre a participação direta das pessoas, a relação 'cara a cara' sobre um território definido, para decidir sobre problemas comunitários e cotidianos, e sua superação. Se trata de "criar uma relação 'convivencial' de participação e poder, longe das formas burocráticas e formalistas tentadas até agora” (Antillano, 2006: 204).

O primeiro passo consiste na delimitação territorial, por meio da definição de polígonos de acordo com o que os habitantes "perciben como su 'comunidad'" (Antillano, 2005 apud Torres, 2011). A poligonal é realizada por meio do processo de manzaneo (em referência às manzanas, os quarteirões/quadras no Brasil), com a definição de "cuántas manzanas hay para conformar el CTU [...] y contar más o menos con cuántas familias se va a conformar” (Nancy Mujica entrevistada por Torres, 2011). Após formada a poligonal e a definição da comunidade, se conforma a Asamblea de Ciudadanos y Ciudadanas ${ }^{31}$, que imprimem "cuerpo, status legal y legitimidad a los mismos, se realiza a través de un proceso de convocatorias" (Torres, 2011). Fomada a assembléia, inicia-se o processo de elaboração da Carta del Barrio.

O instrumento da Carta del Barrio consolida o reconhecimento daquela comunidade. Se entendermos que o reconhecimento parte da dialética entre a identidade interna (os fatores comuns que formam um determinado coletivo) e externa (o que diferencia aquela comunidade das outras), perceberemos a importâncias das Cartas. Em relação ao externo, o barrio se distingue por não ser "formal" ou "regular", e sua identidade se afirma enquanto comunidade que luta pelos direitos da formalidade. Segundo GarciaGuadilla (2006), "la Carta del Barrio que debe elaborar el CTU expresa la identidad de los CTU pues en ella se recoge la historia del barrio desde su fundación y de la comunidad que allí se estableció, su idiosincrasia y tradiciones, así como las normas de convivencia acordadas colectivamente por la

\footnotetext{
${ }^{30}$ Entrevista realizada por Torres (2011: 57).
}

31 "[...] [Dependendo de] la cantidad de familias que sean, o las manzanas que salgan, [van] representantes de cuatro o cinco personas por manzana y se postulan para conformar el CTU. Cuando uno tenga más o menos una idea de cuántos vayan a conformar el CTU, nosotros contamos así a mano alzada [... ] bueno, son doscientas treinta familias, vamos a hacer la primera asamblea con el cincuenta (por ciento) más una personas. Si no, se recogen las firmas y se explica. Se hace la segunda asamblea que son el 30\% [y] si no llegamos tampoco, se vuelve a hacer la asamblea con las personas que aparezcan" (Nancy Mujica em entrevista a Torres, 2011). 
comunidad. El valor político de la Carta del Barrio radica en que, además de dotarles de una identidad común, el acuerdo que establece la comunidad en torno a estas normas mínimas de convivencia compromete a todos los miembros en un proyecto colectivo".

A Carta del Barrio é realizada com o registro dos fundadores e moradores da comunidade, consolidando a história oral de milhares de protagonistas ocultos. Segundo Nancy Mujica, entrevistado por Torres (2011), "la Carta del Barrio se va haciendo a medida que se participa en el CTU. Se va haciendo el censo, se entrevista[n] a las personas que tienen más tiempo en el barrio, que te cuenten la historia [...]. Mucha gente tiene fotos de los barrios anteriores y se la vas pidiendo a las personas”. Torres (2011), a partir de Vich \& Zavala (2004), explica que a Carta del Barrio não se resume a contar a história passada, mas também "rastreando las condiciones de la cotidianidad y buscando los significados que la gente produce sobre su presente, la Carta del Barrio, no sólo registra acerca de lo ocurrido sino que también abre paso para registrar aquello que la gente quiso que ocurriera, lo que creía que estaba ocurriendo y lo que finalmente ocurrió abre paso para registrar aquello que la gente quiso que ocurriera, lo que creía que estaba ocurriendo y lo que finalmente ocurrió". A pedagogia de Paulo Freire muitas vezes é utilizada nas atividades dos CTUs.

Tivemos a oportunidade de acompanhar uma atividade de Transformación Integral del Barrio na favela conhecida como Los Sin Techo. Ao tomarmos contato com a Carta del Barrio, pudemos descobrir que o nome sem-teto faz referência literal à cobertura da casa: "fue así que como se dio la construcción de las paredes sin los techos, puesto que de esta forma dichas estructuras no eran consideradas vivienda, nace así la auto denominación del barrio 'Los Sin Techos". Sem o teto não poderiam ser consideradas casas e, portanto, não poderiam ser demolidas pela polícia. Assim construíam apenas as paredes e improvisavam alguma cobertura de lona.

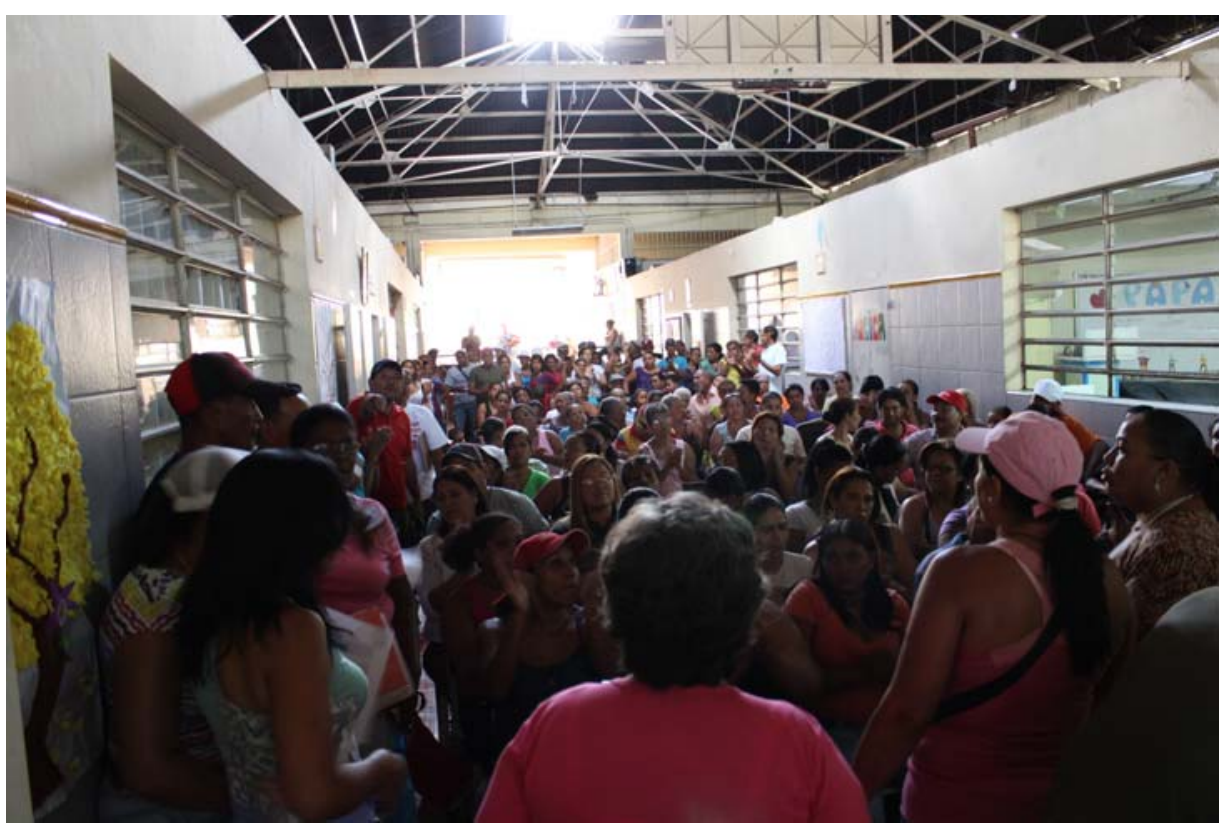

Fig. 19: Assembléia em Los Sin Techo para o programa de Rehabilitación Integral. Foto do autor. 
Carmen Victoria relata um fato interessante que ocorreu no início do processo de reconhecimento das favelas de Caracas. Técnicos da prefeitura não aceitavam realizar os levantamentos cadastrais dentro das favelas, e o a solução encontrada foi a formação de cooperativas de levantamento cadastral formada pelos próprios moradores das favelas.

"Entonces ahí, dijimos, bueno, como el gobierno no está nos dando respuestas, no porque no quiere, sino porque la burocracia y todos los mecanismos no lo perminten, nosostros mismos vamos a hacer la propuesta. Y la propuesta fue crear cooperativas de levantamiento cadastral. El proyecto se le presentó al presidente, y el presidente imediatamente, Chávez dijo: si, va, cuanto necesita? Sacamos la cuenta, y imediatamente nos llama a Miraflores para que... se creó una coperativa de levantamiento cadastral por parroquia, enterada por personas, por familias de la misma comunidad, dispuestas a asumir un aprendizaje, explicandoles a grandes rasgos los más importante del levantamiento, como se hacía. El presidente nos llama a Miraflores y nos entrega el financiamiento, o sea, nos entrega los recursos para iniciar lo que era el levantamiento de cada barrio de la parroquia.

Fue una actitud desde la comunidad o desde el gobierno?

Desde la comunidad.

Porque el gobierno no lograva hacer?

Por trámites burocráticos, entraves con el personal, que el mismos técnicos pensaba: como entrar en ese barrio? En el calejon que no tiene salida? Quien mejor que se encargara del levantamiento de los barrios sino la gente que vivia en los barrios? Como medir, como montarse en una sotea, para ver cual era realmente la dimensión de la casa? Lo que tu medías abajo y lo que medías desde la parte de arriba de la casa? Muy interesante. todo ese trabajo culminó, y en gran manera fue lo que permitió que casi 90\% de los terrenos municipales furen devidamente adjudicados".

Realizou-se assim o levantamento cadastral, que incluía a realização de mapas das favelas, pelos próprios moradores $^{32}$. Os moradores, protagonistas diretos da construção do bairro (e de todo a cidade) com as próprias mãos, agora eram também protagonistas da escrita da história do bairro, por meio da Carta del

32 "Cuando hacíamos el levantamiento catastral, a cada parcela le daban un número. El número de la casa y el número de la manzana. Anteriormente la mayoría de los mapas parecían unos arbolitos; zona verde que era lo que llamaban, pero allí había barrio. Pero con éstos levantamiento nos dieron como el reconocimiento de que ahí había personas viviendo, porque ya teníamos un número; el número de la vivienda más el número de la manzana donde estaba la vivienda de nosotros. Ya no salen arbolitos, sino salen los números. Eso es un logro de nosotros como Comité de Tierras. Por ejemplo en mi sector, donde yo vivo, cuando estábamos haciendo esto [el levantamiento], le íbamos poniendo nombre a las caminerias y en un momento, por mi casa, dijeron: ¿cómo le vamos a llamar a ésta camineria?, y Fernando [miembro de la cooperativa catastral] dijo: jvamos a llamarle caminería La Gordita!, porque ahí estaba mi casa. Y así se quedó: camineria La Gordita" (Entrevista a Migdalia por Torres, 2011:62) 
Barrio, e então pelo desenho próprio que se tornaria oficial e permitiria o reconhecimento por parte do Estado, afinal ${ }^{33}$.

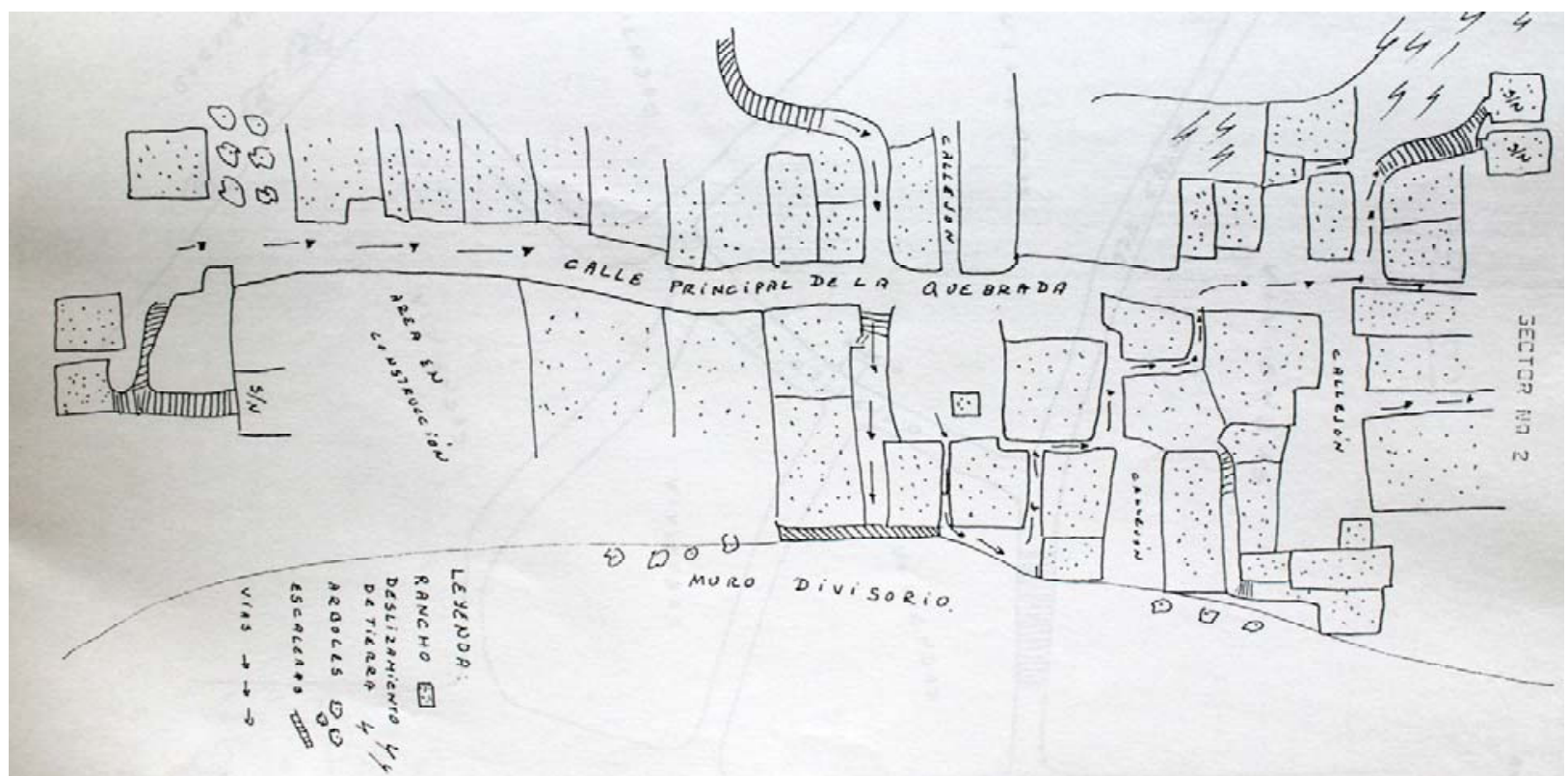

Fig 20.: Mapa de Los Manolos.

Fonte: Acervo pessoal de Carmen Victoria.

Os construtores reconhecem sua própria obra. Reconhecem a produção do lugar e, no lugar, a reprodução da vida - a história oral contada pelos mais velhos. Nas palavras de Torres,

"En la medida que tanto los Comité de Tierras Urbanas como la comunidad comienza a reconocerse en el marco de una historia local que, además de haber sido registrada y elaborada por ellos mismos, los sitúa como hacedores y constructores de esa historia. Ellos/as en tanto sujetos, se van reapropiando material y simbólicamente de las condiciones de re-producción de sus vidas. Una reapropiación que se manifiesta en el ejercicio de nombrar, calles, callejones y escaleras, y la representación cartográfica que le otorga visibilidad al barrio" (Torres, 2011: 62) .

Os CTU assumiram uma importância para além das favelas, ao formarem a base de uma ampla articulação de movimentos urbanos, denominada Movimiento de Pobladoras e Pobladores (MPP). O MPP congrega, além dos CTU, o Movimento de Ocupantes de Edifícios, a Red Metropolitana de

\footnotetext{
${ }^{33}$ Segundo Torres (2001: 59) "Son varias las experiencias de constitución de cooperativas catastrales fomentadas por los CTU y que, dependiendo directamente de la OTN [Oficina Técnica Nacional], tenían como objetivo realizar los levantamientos y las evaluaciones de riesgo que posteriormente debían ser certificados por los catastros municipales".
} 
Inquilinos $^{34}$ e os Campamentos de Pioneros-Nuevas Comunidades Socialistas ${ }^{35}$ (Movimiento De Pobladoras y Pobladores, 2010).

Desde a sua formação, os CTU têm atuado ativamente na definição dos rumos da política urbana, tendo participado da formulação das leis posteriores ao Decreto 1666, com destaque para a Ley Especial de Regularización Integral de la Tenencia de la Tierra de los Asentamientos Urbanos Populares, aprovada em 2006, e sua revisão no ano de 2011. Nas palavras da própria organização, em referência à revisão da lei de 2011, "hemos estructurado la ley atendiendo a principios pedagógicos de técnicas legislativas dirigidos a hacerla más comprensible y facilitar su aplicación, simplificando procedimientos y trámites, desburocratizando el proceso de regularización, otorgándole carácter protagónico y vital a la acción de los Comités de Tierra Urbana (...)" (Comités De Tierra Urbana-Movimiento De Pobladores, 2009: 45).

Nos últimos anos os CTU têm se concentrado na proposta de Transformación Integral de Barrios, que devem abranger, para além da regularização fundiária, obras de infra-estrutura e espaços sócioprodutivos. Para tanto, reivindicam a instalação, dentro das comunidades, de equipes técnicas permanentes, que possam acompanhar os processos de diagnóstico, planejamento, execução e controle dos planos, projetos e obras, assim como assessoria na área de construção paras as famílias que necessitarem. Os principais projetos neste sentido estão concentrados na cidade de Caracas, especificamente no município Libertador.

\footnotetext{
${ }^{34}$ A Red Metropolitana de Inquilinos é formada por famílias que enfrentam situações de despejo, o alto custo dos alugueis, e a especulação (MOVIMIENTO DE POBLADORAS Y POBLADORES, 2010: 21).

${ }^{35}$ Os Campamentos de Pioneros-Nuevas Comunidades Socialistas são organizações de luta pelo acesso ao solo urbano, para a construção de habitação sob um modelo autogestionário de planejamento participativo de projetos integrais de habitat, propriedade coletiva e trabalho solidário (MOVIMIENTO DE POBLADORAS Y POBLADORES, 2010: 21). Em termos organizativos, os Campamentos se assemelham com as organizações vinculadas à União dos Movimentos de Moradia (UMM) no Brasil. Os Campamentos nasceram da experiência dos CTU.
} 


\section{Los Manolos bebe zu Yombre a la Calk Prolongación}

Los Manolos. Fo stherman Guaindez vine a está - Comunidad por primera vez el 2 de Diciembre 1 1958, en compaña de mi cuñado Raul sojo y the esposa, buscando un terreno para una ivivienda; Estaudo ya habilado por Pautalión Mata, Maria de lisners

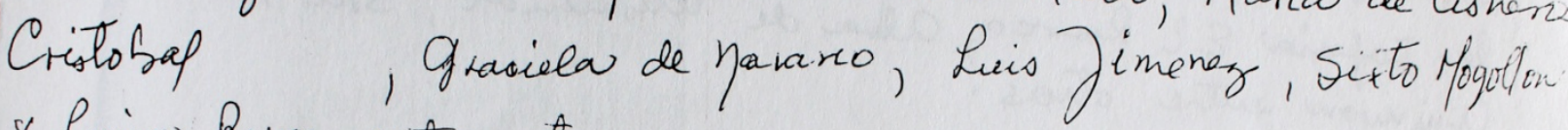
1 h hiso Rojas eutre otrus.

- Tré Creaiendo la Comumidad donde nos organizaros el 13 de febrero de 1959 por Rivisa Rojas, Sixto Moruleow, Aua feón, Jeraw olivier sosefina de Gonzakey y Sthernaw. Empezanos a trabajar las clocoas, hicinos la peticion de Cuz. (Ya que ea que habio era robada). ap or tebareas (I a 2 bolivares) que esturiera al alcause de los habitauts para comprar. Ceables, cemontos, Guena, turas y othos natiricles de Consturciorón) Con el Plan de 'Emergunsió de Wolfang fa. rrazabal hos doná el material fara terminar la fray $2 d a$ Calle, reforando asi las riveiudas

In Oclubre de 1960, el Club de feones de 'incició a la Constre cción de 3 Localis donde funciono ta bapillar Inmasuleada 1 I la Escuela Los Mavolos Ubicada en la Ira calle con del 2do. Calleyón.

Il Arreglo y mobiliario de la bafilla fue donado por los

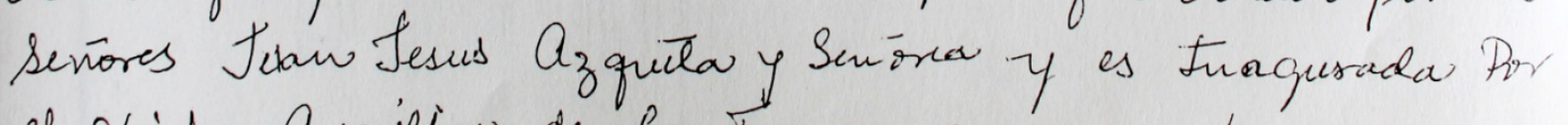
el Obispo Auxiliar de Los Teques Minseñor Boza. Ya Pasados hos años creció hos Manolos, $f$ la Cominielad se integras a la constuceión de muevos facorles y Talleres, El 
Os CTUs tem atuado diretamente junto à Prefeitura de Caracas na conformação de um programa de reabilitação das favelas do município Libertador. Tal programa consiste na montagem de salas técnicas no interior das favelas, nas quais são realizados projetos e planos em conjunto com os CTUs, Consejos Comunales, e demais organizações sociais de base.

O programa está organizado a partir da divisão territorial das favelas do município em 13 grandes áreas denominadas corredores. Em cada corredor são instaladas salas técnicas, com a presença de engenheiros arquitetos e técnicos sociais, que realizam o apoio aos projetos e obras em conjunto com a comunidade. José Rafael, responsável na prefeitura de Libertador pelo programa de reabilitação de favelas, é militante dos CTU.

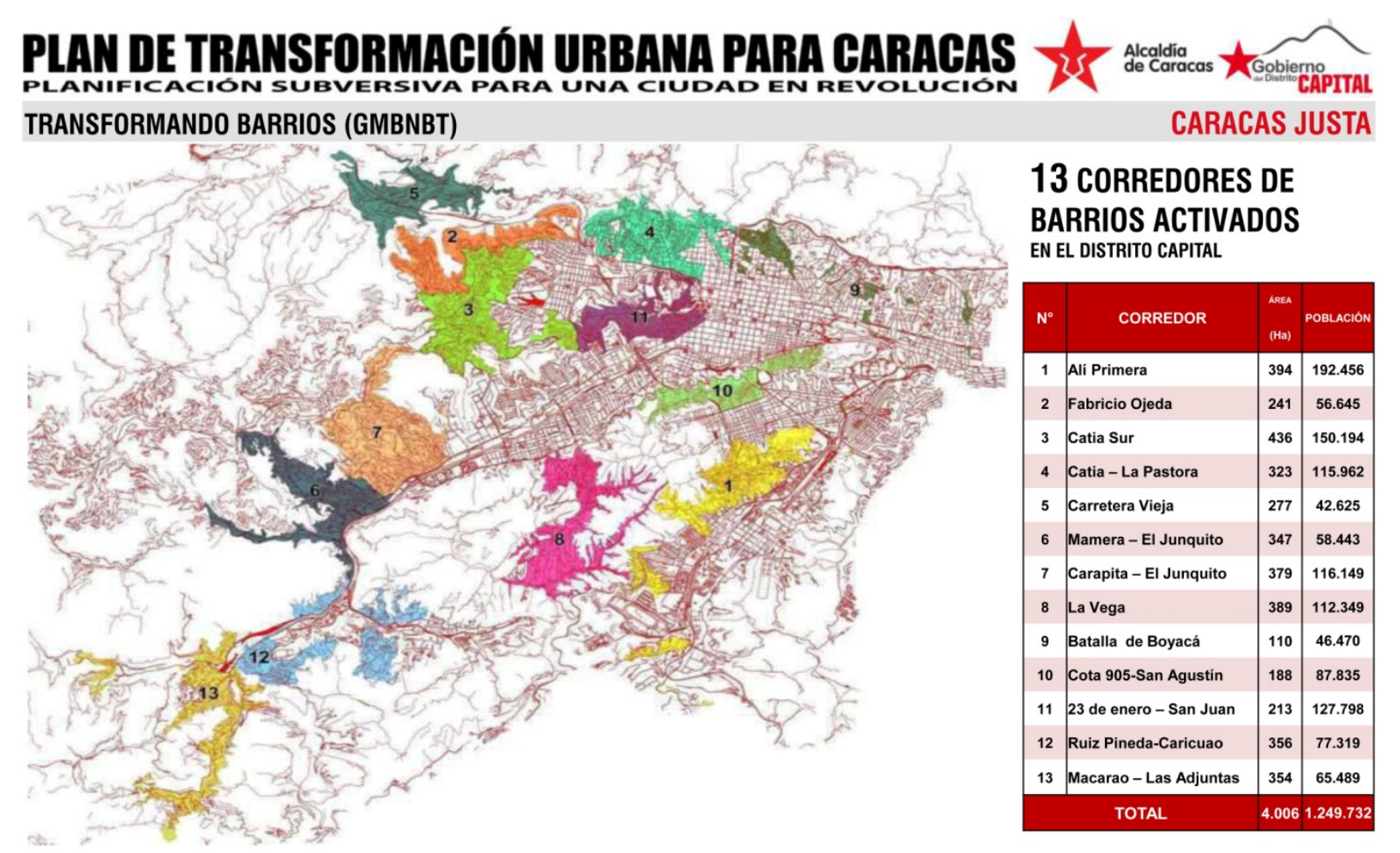

Fig. 22: Apresentação do Programa Gran Misión Barrio Nuevo Barrio Tricolor. 


\subsubsection{O caso do Petare}

O Petare é muito conhecido por duas questões principais: seu tamanho e o nível de violência do bairro.

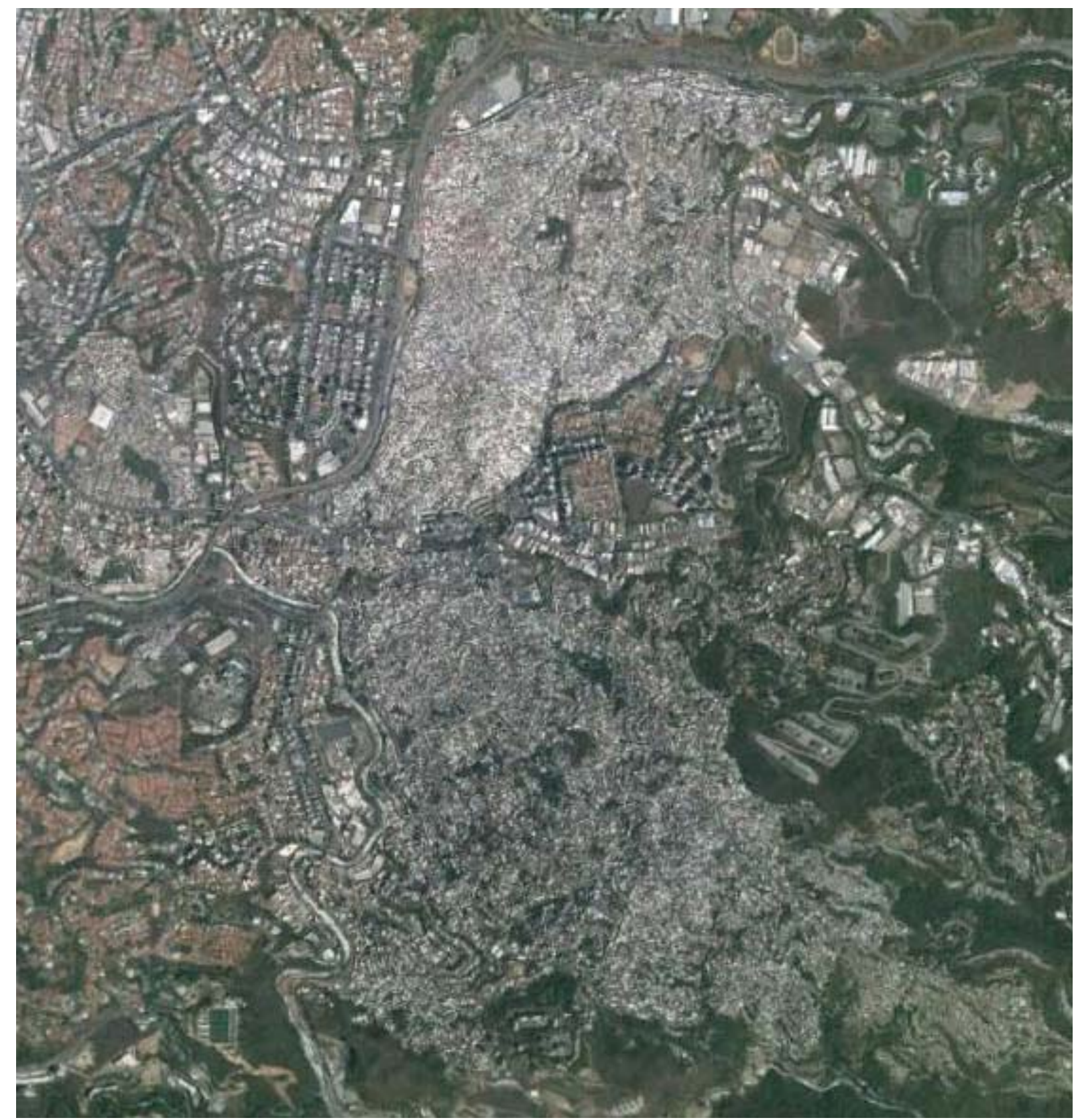

Fig. 23: Favela do Petare norte e sul.

Fonte: Google Earth

Ao contrário de outros grandes barrios, como o 23 de Enero, La Vega e Antínamo, o Petare se localiza na região leste da cidade. Fotografias que mostram o contraste entre o Petare e o bairro de elite à frente, separados por uma via expressa, têm se tornado corriqueiras na simbologia das disparidades sociais da Venezuela. 


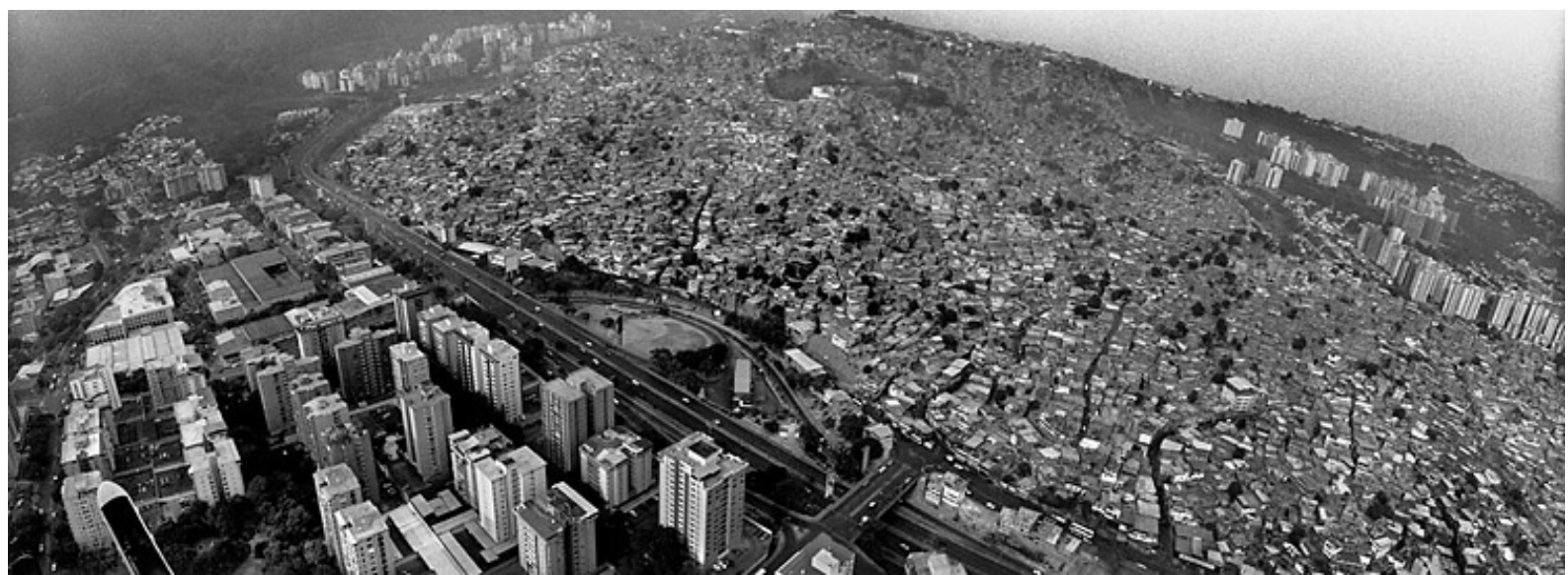

Fig. 24: Favela do Petare.

Foto: André Cypriano

Com 600 mil habitantes e ocupando uma área de 700 hectares, a escala do Petare é, de fato, uma questão que o diferencia dos demais. Para motivo de comparação com as favelas cariocas, a Rocinha, conhecida como a maior favela do Brasil, tem 120 mil moradores em 70 hectares, o complexo do Alemão abriga 69 mil moradores em 300 hectares, e o Complexo da Maré conta com 130 mil moradores distribuídos em 426 hectares $^{36}$.

Em entrevista a Enrique Torres (2011) Alexis Villegas relata que no Petare as Asambleas de Barrios não eram tão fortes quanto as outras favelas: “[...]La lucha de los compañeros de la Asamblea de Barrios, que es netamente de Caracas no se daba en la zona de Petare. En Petare había asociaciones de vecinos, ¿no?, que eran muy partidistas. No eran como la Asamblea de Barrios que son compañeros que estaban más claros en la vaina. Éramos gente que participábamos en apoyo a la comunidad. Por ejemplo, yo siempre fui contrario a Acción Democrática y COPEI, pero la única organización que había era la asociación de vecinos".

De fato, o Petare é conhecido como uma favela com pouco histórico de luta. É também a maior favela da capital localizada fora do município Libertador, historicamente governado pelo chavismo, fazendo parte do município Sucre, normalmente governado pela oposição.

Tivemos a oportunidade de tomar contato com a formação de uma Mesa Técnica de Água no Petare, especificamente no setor José Felix Ribas, onde vivem cerca de 120 mil habitantes e foram conformados cerca de 40 CTUs. A reuniões para a formação da MTA ocorriam dentro da Unidad Técnica Comunal (UTC), uma casa reformada para abrigar a estrutura técnica necessária para os trabalhos da MTA, onde se reúnem distintos atores da favela para a formulação do plano, onde se desenvolve um centro de informações e onde são realizadas reuniões e assembléias.

\footnotetext{
${ }^{36}$ http://portalgeo.rio.rj.gov.br/bairroscariocas/index_bairro.htm
} 


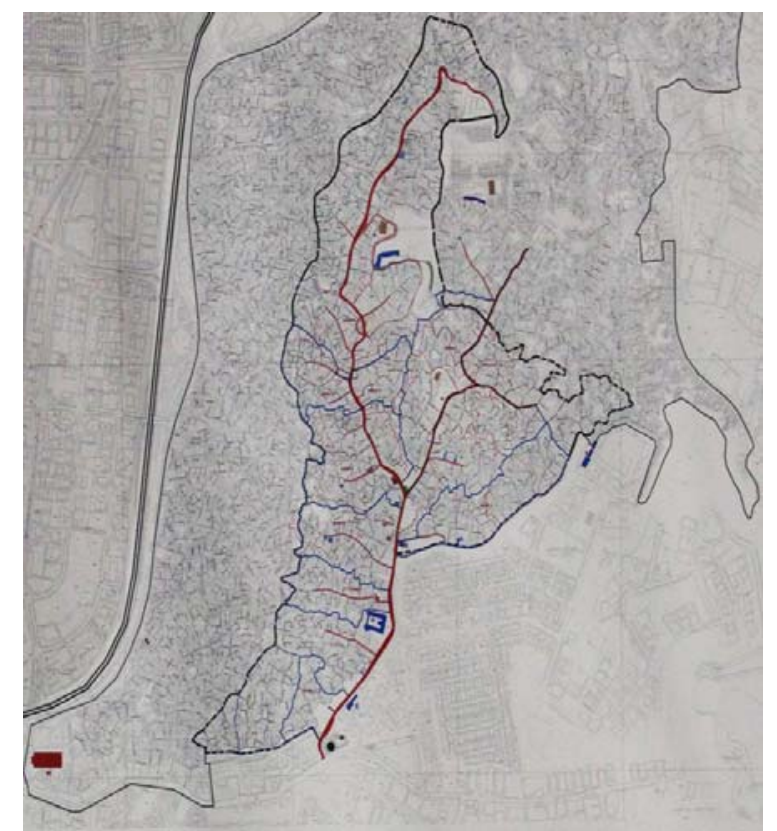

Fig. 25: Setor José Félix Ribas, bacia hidrográfica que representa cerca de metade do Petare Norte.
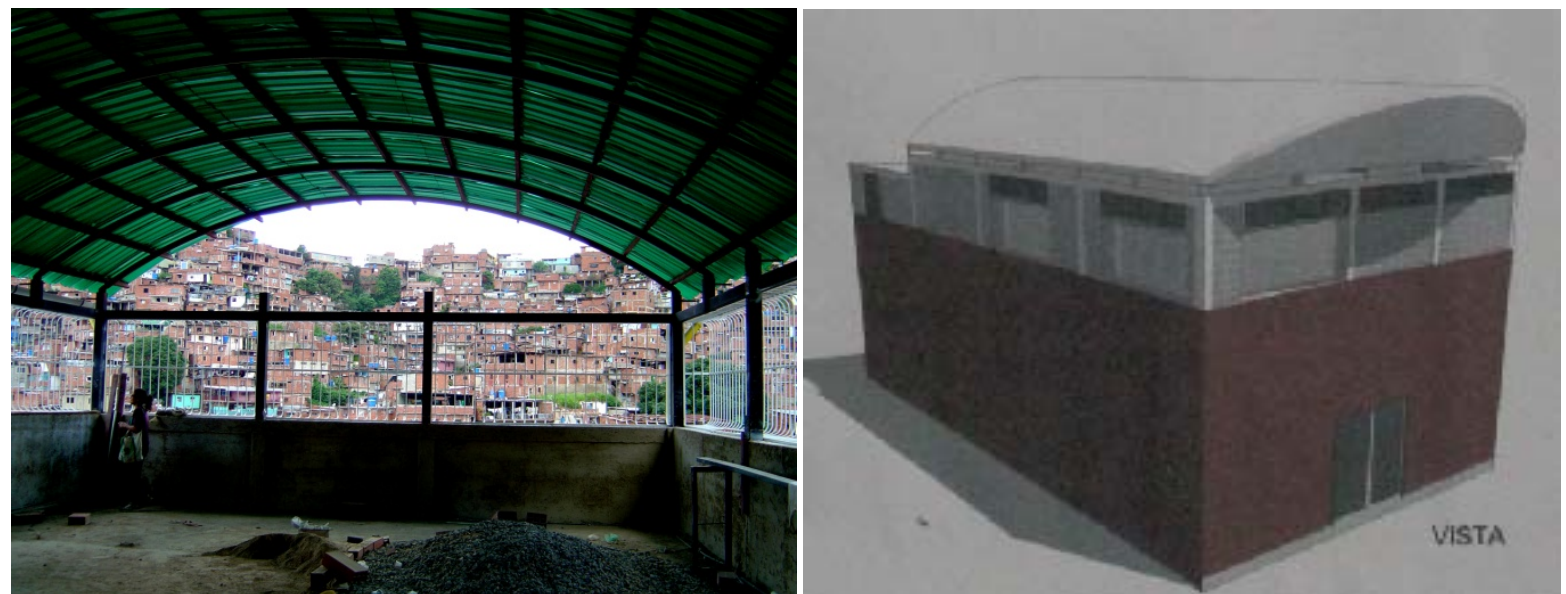

Fig. 26 e 27: Laje de cobertura da Sala Técnica e Maquete eletrônica do projeto de reforma de uma das casas do Petare para conformação da sala técnica.

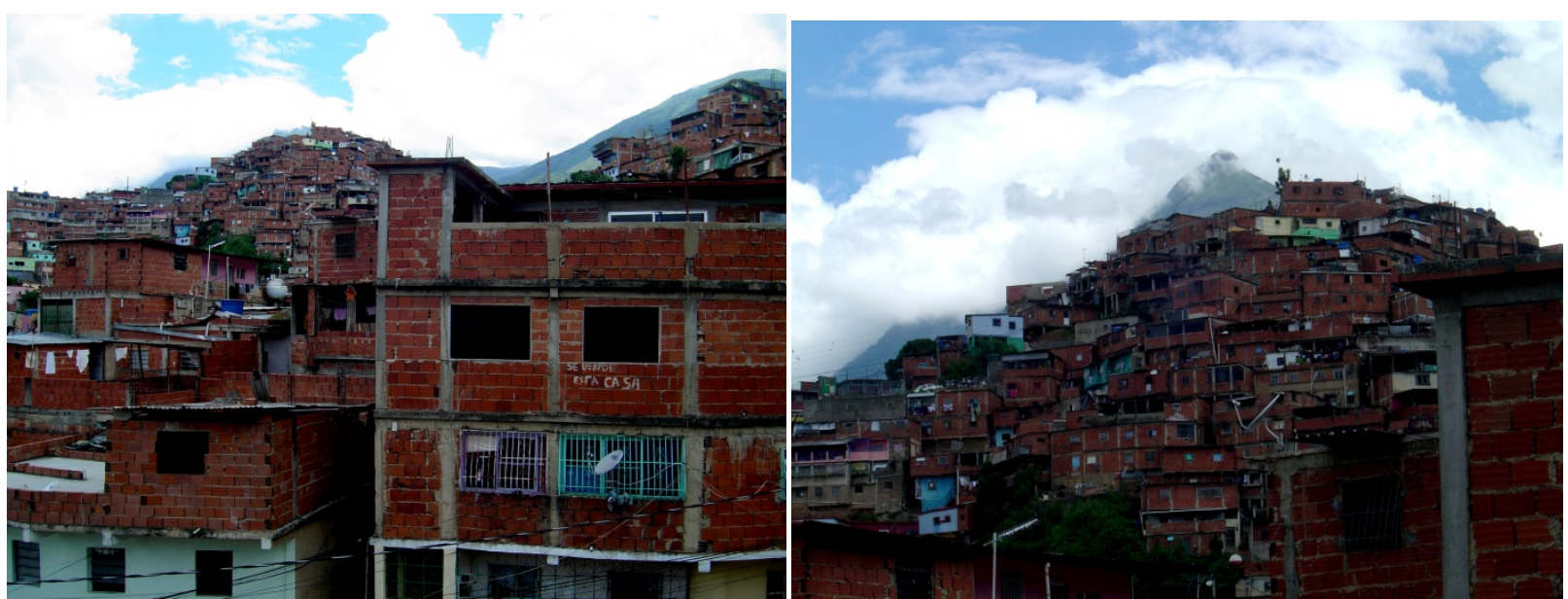

Fig. 28 e 29: Setor José Felix Ribas, Favela do Petare.

\subsubsection{3 de Enero}


A favela 23 de Enero aparece como protagonista em diversos momentos dos últimos 60 anos da história venezuelana.

No dia 18 de outubro de 1945, quando foi derrubado o último general andino, Presidente Medina Angarita e inaugurado o curto período democrático que duraria de 1945 a 1948, surgiu o Barrio 18 de Octubre, conforme Luis Alberto Dugarte Gil: "Este barrio 18 de Octubre fue tomado así por la gente a raíz de la 'revolución de octubre' [...] Me recuerdo muy bien de esos tres días de revolución que hubo por aquí. [...] Una vez culminada la revolución, esas personas se adueñaran de esa zona y construyeron suas casas y suas ranchos". (GIL in PACHECO; ALVAREZ; ROMAN, 1987. apud Baptista, 2011).

A favela 18 de Octubre, que simbolizava a inauguração de um curto período democrático, foi derrubada pela ditadura de Marco Pérez Jimenez para a construção de um projeto moderno tábula-rasa, o 2 de Diciembre. A partir de então, o ditador iniciaria um programa de governo baseado na transformação do meio físico da Venezuela, com grandes obras que indicariam a entrada do país na modernidade. O modernismo de Carlos Raul Villanueva foi largamente utilizado pelo regime, com destaque para a Universidad Central de Venezuela e para os Superblocos habitacionais. Falar nos superblocos é falar de Pérez Jimenez e Carlos Raul Villanueva, o homem do poder e seu arquiteto. Alguns, no entanto, preferem lembrar de outras pessoas, como faz o historiador José Roberto Duque:

"la Historia oficial, incluso en este tiempo, sigue glorificando y escribiendo con letras doradas el nombre del señor arquitecto que se copió de Le Corbusier, pero en ninguna parte están escritos los nombres del señor que metió el cableado en el bloque 20-21, la señora que le cocinaba el desayuno cada día a los hermanos que frisaron y pintaron el boque 50, los hombre y mujeres que organizaron la primera Asociación de Vecinos en el Siete Machos, los fundadores de la primera línera de transporte [...] Estos detalles y personajes anónimos son los que le dan forma a la Historia del Pueblo del 23 de Enero [...]" (Duque, 2010 apud Baptista, 2011)

A queda de Pérez Jimenez foi marcada por um momento de grande mobilização popular, o que incluiu a ocupação, em fase de finalização, dos edifícios do conjunto 2 de Diciembre. A população rebatizou o conjunto de 23 de Enero, nome que é conhecido até hoje. Ao redor das lâminas modernistas, os espaços públicos que a modernidade dedicara ao convívio, ao lazer, foram ocupados por favelas. Desde então, o bairro tem sido identificado como território de resistência popular diante dos diversos governos dos partidos AD e COPEI na chamada IV República. 


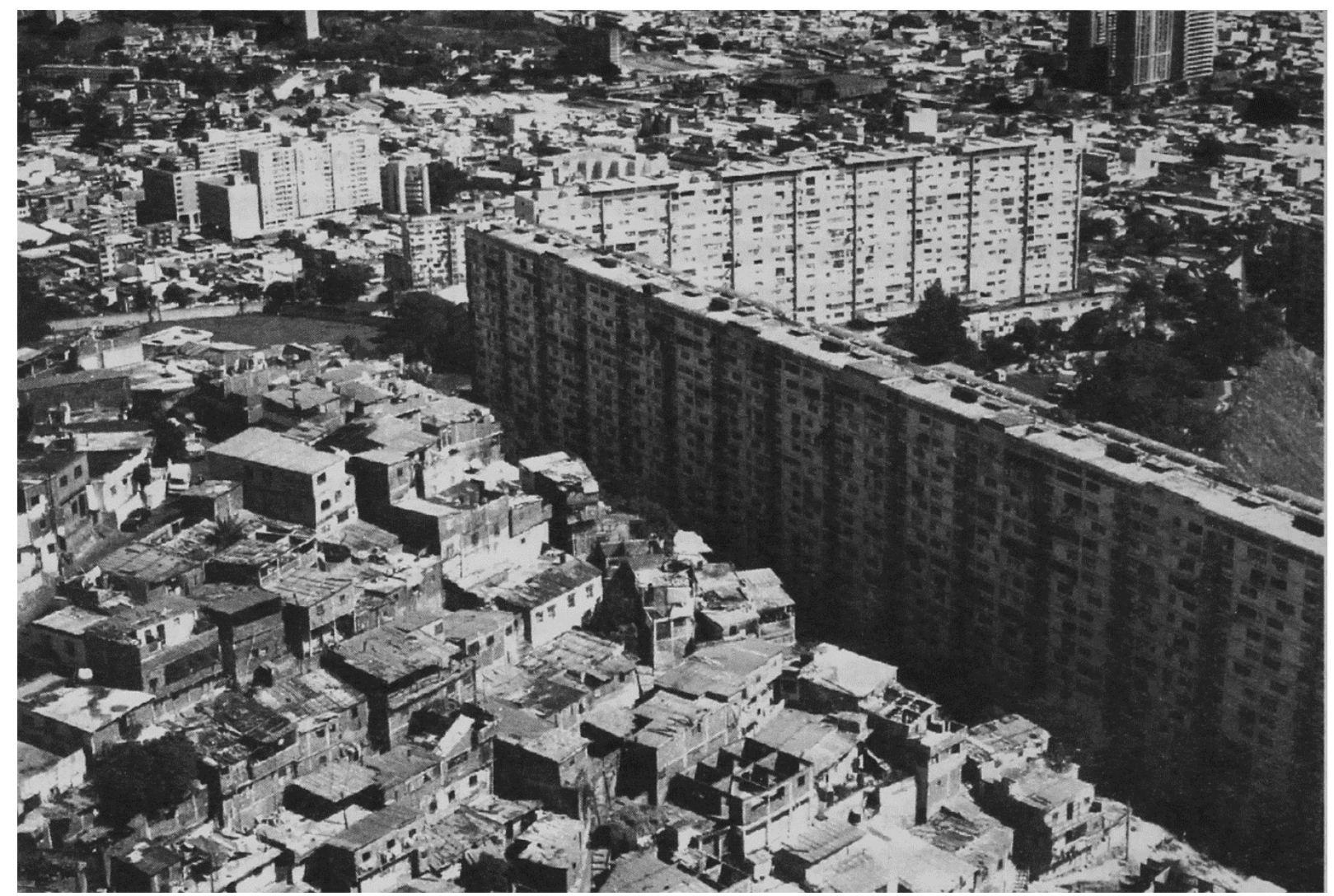

Fig. 30: Os superblocos e a favela.

Foto: Arq. José Miguel Menéndez, Junho de 1992. (Bolívar, 1995)

É impactante a paisagem que emerge do contraste entre a racionalidade levada ao limite por Villanueva e a favela de formas orgânicas que ocupa os espaços vazios. Ambos, favela e lâmina, foram historicamente lugares de resistência ao poder do Estado. Configura-se uma situação curiosa: o conjunto favela (autoconstruída na ausência do Estado) e lâmina moderna (imposta por um Estado autoritário) formou um território histórico de resistência ao poder do Estado.

A histórica de resistência popular do 23 de Enero remete à própria luta contra as remoções das comunidades para a implantação dos superblocos. Naquelas circunstâncias, os principais partidos políticos de oposição ao regime de Pérez Jimenez atuavam junto às comunidades:

"desde el momento de los desalojos la gente ve la necesidad de unirse y organizarse en función de la defensa de sus derechos, asumiendo una posición política. En la población circulaban manifiestos, volantes, comunicados clandestinos de los partidos $A D$, URD y del PCV. Comienza en esta época la práctica de tirar piedras, aunque todavía tímidamente". (Pacheco; Álvares \& Roman, 1987 apud Baptista, 2011).

Um ano depois da queda de Pérez Jimenez 4.000 apartamentos estavam invadidos. Se inicou um processo de organização em determinados blocos. Destaca-se, entre as organizações, a Junta Representativa del 23 de Enero, que entre outras ações se dedicou a expulsar da comunidade moradores vinculados aos órgãos repressivos da ditadura (Baptista, 2011), assim como passou a assumir um processo de resistência às tentativas de remoção do governo com a formação de brigadas armadas. Em 
meio à resposta do Estado frente a formação de um poder paralelo, formou-se nos blocos os Comités de Autodefensa. Durante as décadas de 1960 e 1970, o 23 de Enero foi território de diversos grupos guerrilheiros, como os Tupamaros - em referência à guerrilha urbana dos Tupamaros no Uruguai.

Finalmente, o dia 4 de fevereiro de 1992 é ainda outra data que o 23 de Enero participou como protagonista. Neste dia Hugo Chávez comandou sua tentiva de golpe contra o presidente Carlos Andrés Pérez a partir do Cuartel de la Montaña, a primeira Academia Militar da Venezuela incrustada no meio do 23 de Enero. Foi naquela localidade que Chávez realizou um pronunciamento aceitando a derrota da sublevação, porém, "por ahora". Hoje o quartel é conhecido como 4F, onde Chávez está enterrado.

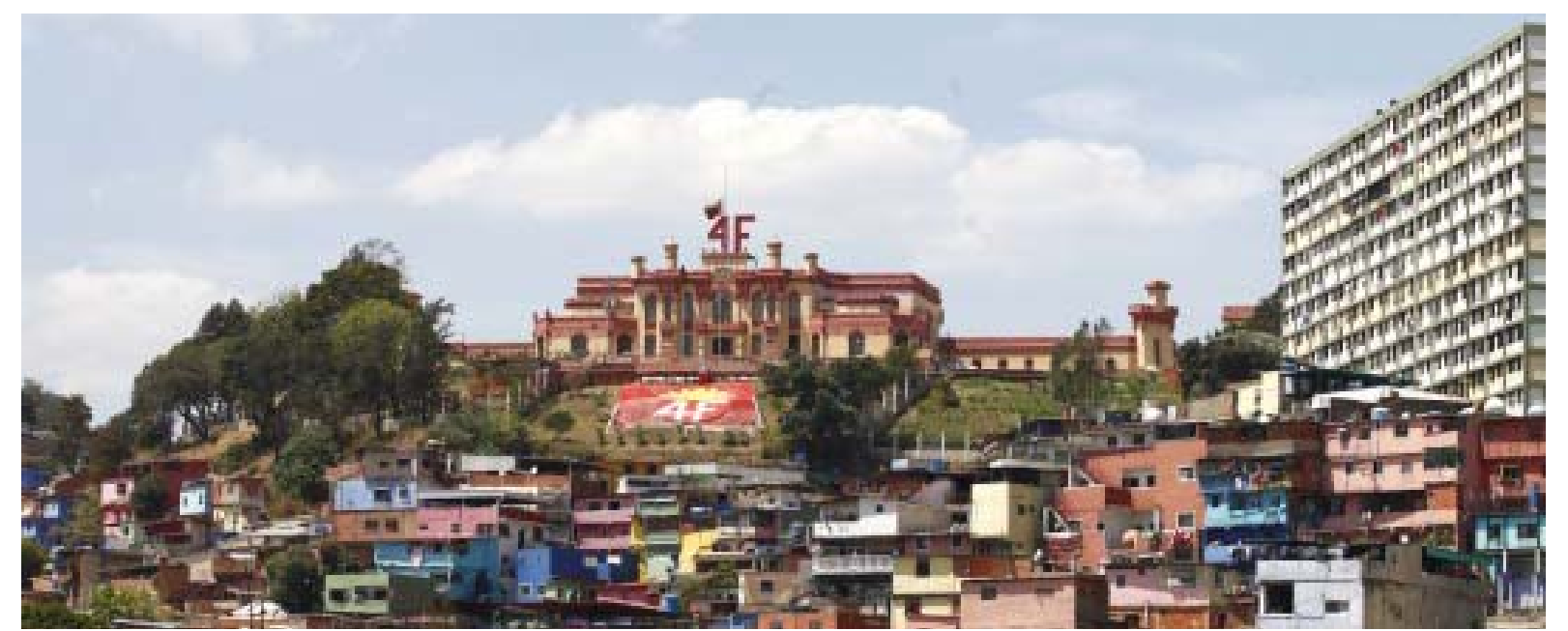

Fig 31: No 23 de Enero, entre a favela e superblocos encontra-se Cuartel de la Montaña, atual 4F, onde Hugo Chávez está enterrado.

Em termos territoriais, o 23 de Enero se localiza em uma posição fundamental na cidade de Caracas. O bairro está localizado praticamente vizinho ao Palácio presidencial de Miraflores. No dia da vitória de Hugo Chávez nas eleições de 2012, uma grande comemoração ocorreu no estacionamento de Miraflores, enquanto nas ruas ao redor centenas de jovens de carros e motos desciam o morro e ocupavam as ruas do centro histórico da cidade. Além do 23 de Enero, ao redor de Miraflores se localizam diversas ocupações do movimento de moradia apoiadoras do chavismo. É comum escutar que este conjunto forma um território de proteção ao palácio contra tentativas de golpes, a exemplo do que ocorreu em 2002. 


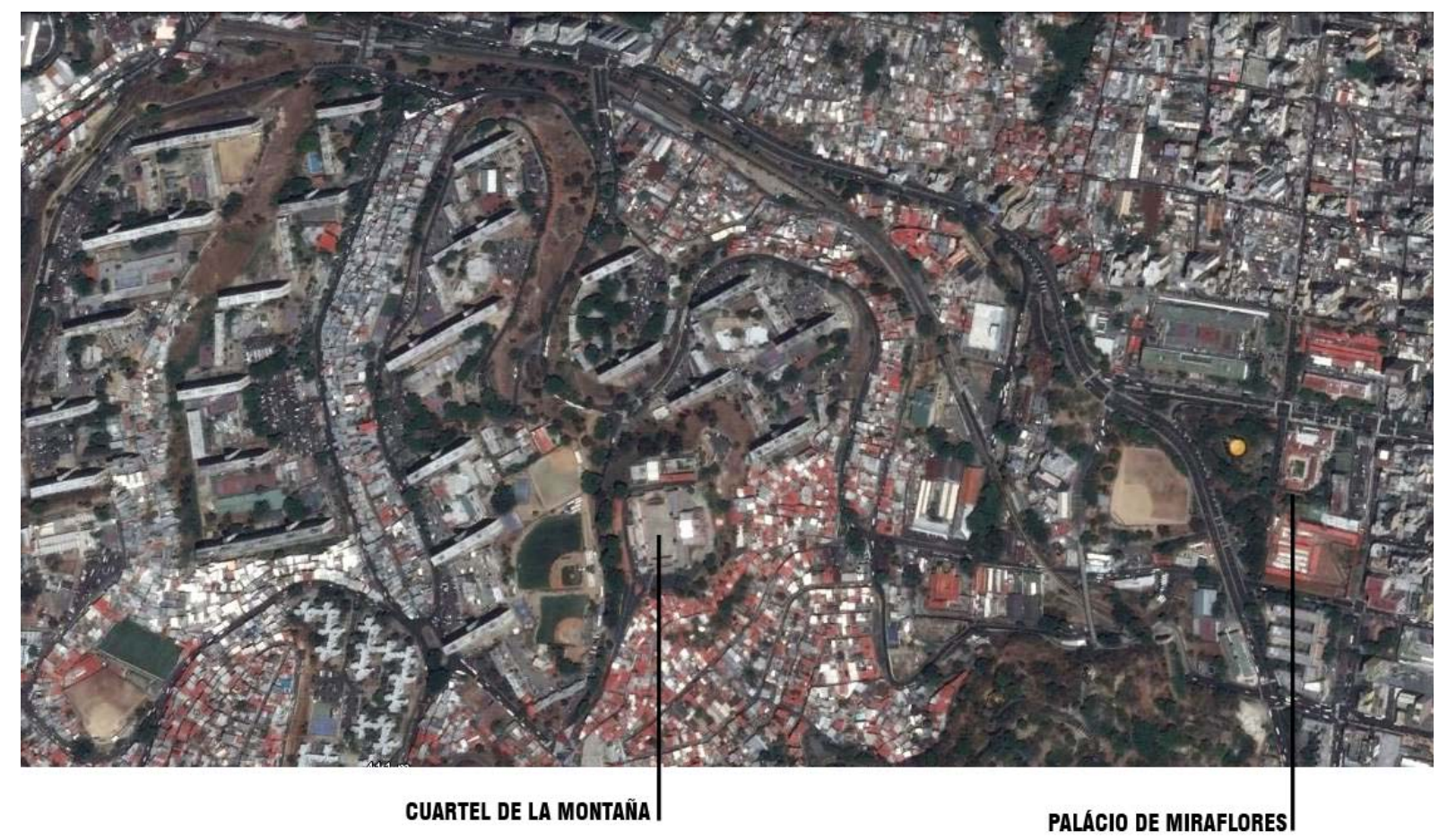

Fig. 32: 23 de Enero.

Elaboração própria.

Fonte da imagem: Google Earth.

No 23 de Enero também foram formados os CTUs, com o objetivo de regularizar as favelas que enviolviam os superblocos. Segundo Mariana Bruce, em estudo sobre o bairro, "os próprios membros do Comité de Tierras foram submetidos a talleres explicativos - uma espécide de cursos técnicos para que aprendessem noções básicas de engenharia e outros conhecimentos para levarem a cabo o projeto" (Bruce, 2011: 141).

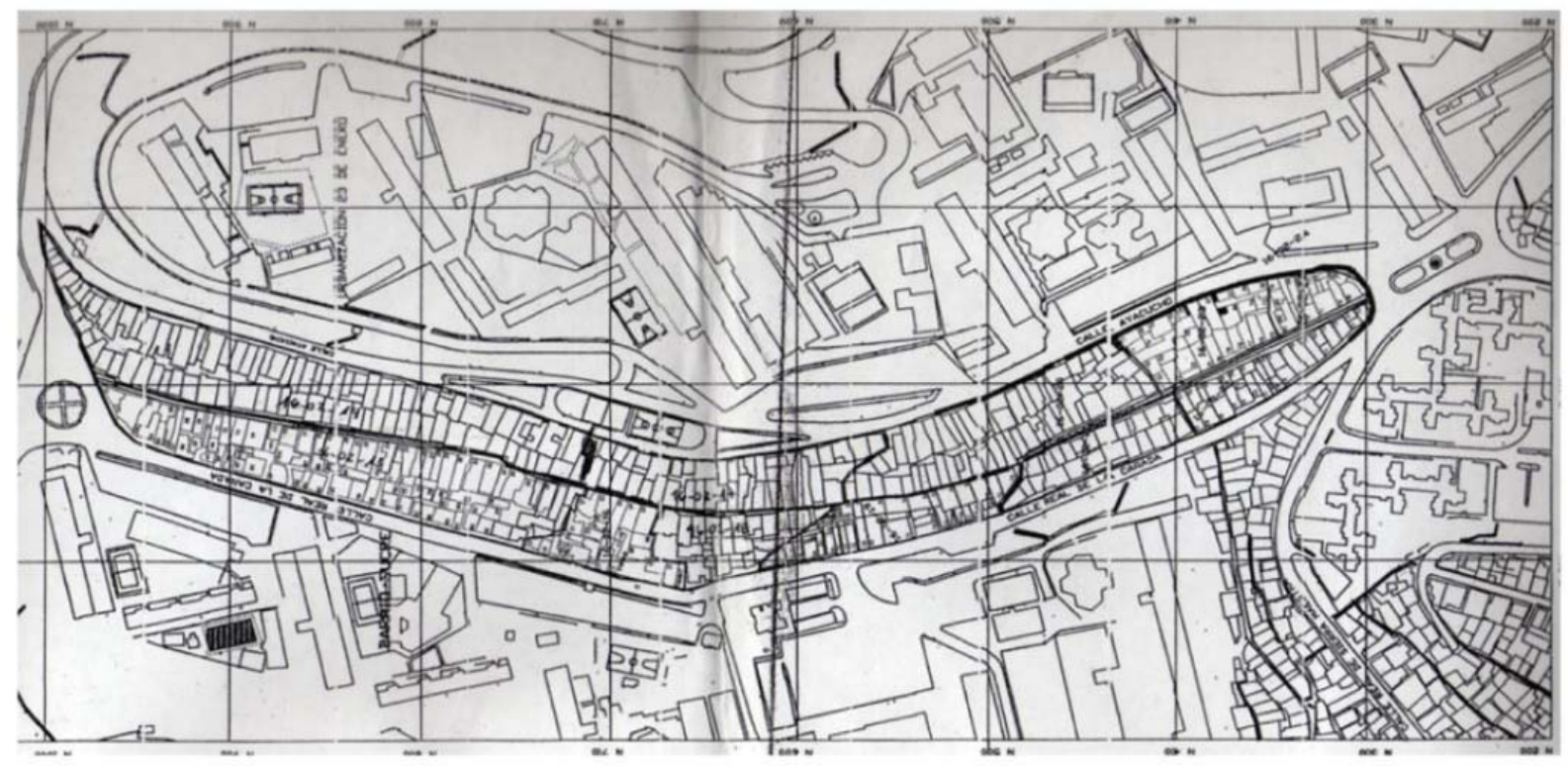

Fig. 33: Croqui do bairro Sucre, realizado pelo CTU. Fonte: arquivo CTU/Barrio Sucre, em Bruce, 
César Rivas, membro do CTU, narra o processo de capacitação para o cadastramento, assim como a história narrada por Carmen Victoria sobre a formação das cooperativas de cadastramento: "Luego que fuimos elegidos, fuimos preparados [...] Hicimos algunos talleres [...] y luego de las charlas preparativas e eses talleres fuimos inducidos al trabajo de campo [...] que significaba una recolección de informaciones catastrales en una planilla que es un levantamiento catastral. [...] En principio tuvimos la instrucción de los funcionarios y, luego, guiados por nosotros del CTU" (entrevista a Bruce, 2011: 142).

A regularização das favelas é uma frentes que marcam a política habitacional a partir de 1999, quando Hugo Chávez entra no poder. No entanto, outras frentes são lançadas, com maior ou menor êxito.

Em 1990 foi reestruturada a Lei de política habitacional. Josefina Baldó, professora da faculdade de Arquitetura e Urbanismo da Universidad Central de Venezuela, histórica defensora e pesquisadora da questão dos barrios, em texto publicado em junho de 2004, explicava os avanços da política habitacional naquele período:

"Desde 1989 Venezuela contaba con unas de las condiciones esenciales para enfrentar el problema de la vivienda: la disposición, por Ley, de 5\% del presupuesto ordinario del Estado para inversión en vivienda y la creación del ahorro obligatorio equivalente al $3 \%$ de los sueldos y salarios para el mismo fin. En concordancia con la transformación estructural de la política, la nueva Ley de Vivienda elaborada en CONAVI, promulgada y reglamentada entre fines de 1999 y mediados de 2000, entre muchos otros avances direcciona estos fondos a la atención de los sectores sociales tradicionalmente preteridos. Concretamente, a más de 90\% de la población que hoy no puede acceder a la vivienda sólo por sus propios medios. Así, establece que el Fondo de Aportes del Sector Público (FASP nutrido por el 5\% del presupuesto) es de solidaridad social, para emplearse totalmente en programas no reproductivos y en subsidios directos a la demanda individual (hasta 11.500 dolares por familia), inversamente proporcionales al nivel de ingresos familiares, mientras que el Fondo Mutual (aporte y propiedad de más de 2 millones de ahorristas) es para la capitalización individual, básicamente mediante créditos que generen interesas pasivos reales positivos".

Josefina Baldó presidiu o Consejo Nacional de Vivienda (CONAVI) a partir de 1999 durante 20 meses. Com Baldó a política foi estruturada a partir de 6 programas centrais:

- Atención a los pobladores de la calle;

- Habilitación física de las Zonas de barrios;

- Mejoramiento y ampliaicón de casas de barrios y urbanizaciones populares; 
- Rehabilitación de Urbanizaciones populares y Cascos Tradicionales;

- Nuevas urbanizaciones y viviendas de desarrollo progressivo,

- Viviendas Regulares.

Fora da gestão, Baldó se tornou crítica ao regime e à política habitacional, que não deu continuidade ao planejamento e às ações iniciadas. A política habitacional, até a criação do Gran Misión Vivienda Venezuela, de fato é a história de grandes descontinuidades e pouco efetividade. Em muitos casos, a política implementada foi de cunho militarista, como as Petrocasas e a Misión Barrio Nuevo Barrio Tricolor, cuja proposta de requalificar as favelas acabava por se transformar em ações pontuais, superficiais e autoritárias levadas a cabo por militares.

\subsection{O Gran Misión Vivienda Venezuela}

O anúncio da criação do Gran Misión Vivienda Venezuela foi realizado durante o programa televisivo Aló Presidente de 11 de fevereiro de 2011. É comum ouvir na Venezuela que Hugo Chávez chegava a governar por meio deste programa, ao anunciar medidas, comunicar ministros, tomar decisões ao vivo. $\mathrm{O}$ Aló Presidente era um programa semanal que ocorria todos os domingos e durava cerca de 6 horas ${ }^{37}$.

O Aló Presidente número 370 foi transmitido a partir da Ciudad Socialista Caribia, um empreendimento habitacional de grande porte realizado em convênio com o governo cubano.

Dois meses depois, a revista Debates IESA ${ }^{38}$ - Instituto de Estudios Superior de Administración, influente instituição opositora ao regime chavista, dedicou sua edição de abril de 2011 ao tema habitacional. A revista trazia reflexões sobre outras experiências latinoamericanas, como a colombiana e dominicana, e defendia o modelo chileno de política habitacional. Em artigo intitulado "Las lecciones de Chile", o instituto defendia que "los países que encabezan la construcción de viviendas en el mundo comparten dos factores: inversión privada en la construcción de vivienda y un sistema hipotecario que financia la demanda".

O IESA, ao defender o modelo chileno, se posicionava contra o formato do recém criado Gran Misión Vivienda Venezuela. Pois a proposta do programa chavista se baseava na intervenção direta do Estado nos chamados 5 vértices: 1. Povo: Registro Nacional, 2. Terrenos, 3. Executores, 4. Financiamento, e 5. Materiais de Construção.

\footnotetext{
${ }^{37}$ http://www.alopresidente.gob.ve

${ }^{38}$ Interessante remeter às palabras de Oscar Varsavsky na época de fundação do IESA: "(...) acaba de inaugurarse el Instituto de Enseñanza Superior de Administración IESA, fundado por empresas privadas - Creole y otras - con el auxilio técnico de cinco universidades norteamericanas y apoyo financiero de la Ford, para impartir una enseñanza moderna y eficiente, con las últimas técnicas de management, uso de computadoras, racionalización de oficinas, etcétera. Este Instituto competirá ventajosamente con otro análogo que tiene el Gobierno, a pesar de que éste también está tratando de modernizarse, y entonces el problable resultado es que en el futuro, los cargos de responsabilidad en la administración pública y privada será ocupados por graduados del IESA, muy eficientes pero con una mentalidad formada según los valores y hábitos norteamericanos. Es innecesario explicar los alcances políticos que pueden tener estos dos ejemplos". (Rietti, 2007: 208)
} 
Neste contexto, não deixa de chamar atenção a cooperação técnica entre os governos brasileiro e venezuelano na temática habitacional. Pois o governo brasileiro pouco teria a contribuir, a partir da experiência do programa Minha Casa Minha Vida, em temas que tratam da intervenção direta do Estado na execução das moradias, materiais de construção e terrenos. Talvez seja esse o motivo pelo qual a cooperação internacional Brasil-Venezuela não tenha sido realizada por meio do Ministério das Cidades, e sim pela Caixa Econômica Federal. A própria presidente da Caixa Econômica Federal na época da criação do Minha Casa Minha Vida, Maria Fernanda Coelho, realizou viagens periódicas à Venezuela no início do programa Gran Misión Vivienda Venezuela. Segundo Maria Fernanda, a cooperação brasileira contribuiu na formação do Órgano Superior de Vivienda e na elaboração de sistemáticas operacionais baseadas nos pontos de controle do Minha Casa Minha Vida. A CEF mantém escritório fixo na cidade de Caracas desde outubro de 2009, inaugurado com a presença do presidente Luiz Inácio Lula da Silva e da então ministra da Casa Civil Dilma Roussef, recebidos pelo então chanceler Nicolás Maduro ${ }^{39}$. A CEF tem realizado assessoria na instalação de terminais bancários em bairros populares, como medida do governo venezuelano na ampliação do acesso das comunidades mais pobres ao sistema bancário estatal.

As diferenças entre MCMV e GMVV são evidentes, sobretudo no nível de intervenção do Estado nos vários temas da política habitacional. Nessa perspectiva, é curiosa a forma como Rui Falcão, presidente do Partido dos Trabalhadores, se refere ao programa venezuelano:

"Essa cópia detalhada do projeto brasileiro vai da urbanização das favelas até a forma dos contratos de financiamento, e conta com uma ajuda de peso: a ex-presidente da Caixa Econômica Federal Maria Fernanda Coelho vai ao país uma vez por mês dar assessoria técnica aos venezuelanos. Ela atende a um pedido do próprio ex-presidente Luiz Inácio Lula da Silva. Apesar de recente, o Minha Casa, Minha Vida já entrou na pauta de cooperação externa do Brasil. Hoje há seis países africanos e latino-americanos que recebem ajuda brasileira para implantá-lo." ${ }^{40}$.

\subsubsection{Registro Nacional}

O tema denominado como "Povo: Registro Nacional de Vivienda", se refere ao processo de registro levado a cabo nos meses iniciais do programa GMVV, que teve como função identificar a demanda de famílias que necessitam de habitação própria ${ }^{41}$ ou que necessitam remodelar, legalizar ou ampliar seu domicílio.

O processo de registro evidencia o caráter dado de "missão", forma de atuação recorrente nas políticas públicas chavistas; foram denominadas missões todas as políticas públicas sociais, a exemplo da

\footnotetext{
39 também foi nessa ocasião que Chávez e Lula se reuniram para assinar acordo sobre a refinaria Abreu e Lima que envolveria Petrobrás e PDVSA.

${ }^{40}$ http://ruifalcao.com.br/modo-petista-de-governar-e-copiado-por-65-paises

${ }^{41}$ Destaca-se a utilização do termo "habitação própria"; de fato, o governo resume o atendimento habitacional à propriedade da casa, retirando do horizonte de possibilidades outras formas de atendimento, como o aluguel social.
} 
Educação (Misión Robinson) e Saúde (Misión Barrio Adentro). As missões remetem à urgência, ao trabalho coletivo, às brigadas de trabalho.

Uma vez finalizado o processo de registro, se realiza um processo de análise e verificação dos dados por meio de visita casa por casa, com os chamados quartetos. Os quartetos são compostos por, nas palavras do governo, "un luchador o luchadora social, un vocero o vocera de los movimientos sociales, un brigadista del registro y un integrante de la Milicia Bolivariana". Até o mês de julho de 2011 haviam se conformado 2 mil quartetos, nos quais participaram 8 mil voluntários.

Segundo o governo, esta é a primeira vez que a população conta com um registro único de demanda habitacional.

O resultado do registro nacional de vivienda apontou a necessidade de aproximadamente 3 milhões de novas habitações e 1 milhão de unidades que necessitam de algum tipo de reforma.

\subsubsection{Terrenos}

Foi calculada a necessidade de 34.793 hectáres em todo o território nacional para que seja viabilizada a meta de construção de 2 milhões de habitações.

\begin{tabular}{l|l|l|l}
\hline Ano & $\begin{array}{l}\text { Necessidade de } \\
\text { Terrenos (ha.) }\end{array}$ & $\begin{array}{l}\text { Terrenos } \\
\text { Disponíveis } \\
\text { (ha.) }\end{array}$ & $\begin{array}{l}\text { Terrenos a serem } \\
\text { designados (ha.) }\end{array}$ \\
\hline 2011 & 2.806 & 2.806 & \\
\hline 2012 & 3.571 & 3.571 & \\
\hline 2013 & 5.683 & 1.437 & 4.087 \\
\hline 2014 & 5.683 & & 5.683 \\
\hline 2015 & 5.683 & & 5.683 \\
\hline 2016 & 5.683 & & 5.683 \\
\hline 2017 & 5.683 & & 5.683 \\
\hline TOTAL & $\mathbf{3 4 . 7 9 3}$ & $\mathbf{7 . 8 1 4}$ & $\mathbf{2 6 . 8 1 9}$ \\
\hline
\end{tabular}

Quadro 4: Disponibilidade e Necessidade de Terrenos para o GMVV.

Fonte: Site do GMVV (www.misionvivienda.gov.ve) acessado em junho de 2013.

Segundo o site oficial do programa na internet está em andamento a avaliação de uma base de terrenos de 720.000 hectares para determinar sua aptidão para a construção de habitações. Esta avaliação está sendo realizada por uma equipe multidisciplinar e interinstitucional coordenado pela Vicepresidencia de Desarrollo Territorial. A análise preliminar se dá segundo os seguintes critérios: Distância dos centros povoados (dentro da zona periurbana de centros povoados no país, em um raio de $5 \mathrm{~km}$ ), acessibilidade, declividade, capacidade do uso da terra (capacidade e vocação, aqueles com capacidade agrícola são excluídos), risco sísmico e Áreas sob Regime de Administração Especial (áreas em condição de conservação de ecosistemas particulares). 
Para a viabilização dos terrenos foram criadas as Áreas Vitales de Viviendas y Residencias (AVIVIR) e as Áreas de Emergencia Habitacional (AREHA), estas últimas demarcadas na zonas declaradas de risco (ZORI), perigo potencial (ZOPO) ou perigo iminente (ZOPI), como forma de proteção às famílias localizadas nestes espaços. Estes instrumentos foram criados mediante a Ley de Emergencia para Terrenos y Vivienda. Segundo este lei "se declararán de utilidad pública, interés social e importancia estratégica, los inmuebles no residenciales, así como, los terrenos urbanos o rurales abandonados, ociosos, subutilizados o sobre los que exista un uso inadecuado a los fines del Poblamiento, para el buen vivir de la población en las Áreas Vitales de Vivienda y de Residencias (AVIVIR). Igualmente, se declaran de utilidad pública e interés social, aquellos bienes esenciales que el Ejecutivo Nacional califique como necesarios para la ejecución de proyectos habitacionales". Nas AVIVIR, segundo a lei, "el Estado procederá a reordenar integralmente el territorio, para destinarlo con prioridad y con urgencia, a la construcción de viviendas. (...) En estas áreas, el Ejecutivo Nacional podrá establecer un régimen específico contentivo de condiciones especiales en el ámbito del reordenamiento territorial, laboral, de seguridad, de orden público, de servicios, simplificación de trámites administrativos, incentivos, regulaciones y cualquier otro tipo de medidas, que coadyuven al cumplimiento expedito de los objetivos de la presente Ley".

É interessante mencionar a maneira como a Avivir foi exposta de forma abrangente. Foi no programa televisivo Alo Presidente, realizado todos os domingos no qual Hugo Chávez aborda ao vivo as principais questões que estão sendo trabalhadas pelo governo, ao lado de ministros e assessores. Durante um Alo Presidente de 2011, Chávez expôs da seguinte forma a criação desta figura: "Ahora, además de eso la Ley crea otro tipo de área, que ya son las áreas no de riesgo, sino de no riesgo, la otra cara de la moneda pues, las áreas donde hay, o área donde hay condiciones ideales o buenas, o muy buenas u óptimas para la construcción de viviendas, la hemos llamado AVIVIR, Áreas Vitales de Vivienda y Residencia, AVIVIR, y eso tiene además por dentro un significado espiritual, vamos a vivir, vamos a salir de allá de la zona de peligro, AVIVIR, esta es un AVIVIR, AVIVIR". Em tal discurso Chávez lançava mão de sua já conhecida capacidade comunicacional, assim como em 1999, durante a tragédia de Vargas, inventara a "dignificación" - as ações políticas que transformariam os atingidos pela torrente, os "damnificados", em "dignificados". Para além da polômica sobre os traços populistas que traz a conexão direta do "líder" com as "massas", que não cabe neste trabalho, fato é que a exposição das AVIVIR em rede nacional, e com tal força simbólica, acabou por transformá-la em um figura massivamente conhecida.

Até o final de 2011, segundo a Memoria y Cuenta 2011 do Ministerio de Vivienda, foram decretados no total 219 AVIVIR que juntos conformavam 6.500 hectares. Há ainda a informação de que este número é ainda maior, segundo pesquisa da ONG Provea, "el viceministro para el área territorial, Rafael Ramírez, explicó que el Gobierno Nacional tiene disponibles por un área global de 21.000 hectáreas, lo cual permite la construcción de 525.250 viviendas y se mantienen en la búsqueda de otras 40.000 hectáreas. 
Agregó que del total de las áreas disponibles para la construcción se han decretado como áreas AVIVIR 11.719 hectáreas, distribuidas en 19 estados del país"42.

As AVIVIR são semelhantes às ZEIS (Zonas Especiais de Interesse Social) no Brasil. No entanto, na Venezuela são demarcadas pelo executivo nacional. Historicamente o Estado venezuelano aborda a questão da terra de forma distinta ao brasileiro. É interessante, a partir da perspectiva do planejamento urbano no Brasil, que não conta com a tradição de constituição de bancos de terra, a posição crítica de Cilento Sarli em relação a esse tipo de ação na venezuela: “Tanto el Banco Obrero-INAVI como Fondu mantuvieron desde su fundación uno de los componentes fundamentales del viejo paradigma de la vivienda, cual era la generalizada idea de que el poder nacional debía constituir 'banco de tierra' con el fin de garantizar la disponibilidad y precios accesibles para la producción de viviendas de bajo costo. Durante muchos años sostuvimos también esa idea, y será con el inicio de las discusiones acerca de la necesidad de descentralizar el poder público, en la década de los ochenta, cuando se comenzó a desmontar el mito de los bancos de terrenos urbanos, especie de mecanismo para el acaparamiento de tierras por las instituciones del poder nacional, fundamentado básicamente en la ausencia de políticas de tierras urbanas, y en el menosprecio y desconfianza hacia la institución municipal (...) En varias oportunidades presenciamos el caso de municipios en los que las únicas tierras públicas disponibles estaban en manos del Inavi; por su parte, los municipios se desprendieron irresponsable $e$ improductivamente de sus ejidos”. (Cilento Sarli, 1999: 50)

Cilento Sarli defendia o fim do velho paradigma, no qual o Estado se colocava como interventor direto nas diversas fases da viabilização da habitação, sendo a formação do banco de terras um dos problemas. O novo paradigma seria a redução da intervenção estatal, e o aumento das atribuições aos novos moradores nos chamados desarrollos progresivos. Durante o lançamento do Gran Misión Vivienda Venezuela era o modelo chileno que se colocava como a alternativa de uma política habitacional de um Estado não interventor, desta vez defendida pelo IESA. A proposta do Gran Misión Vivienda Venezuela recoloca o Estado como interventor direto em todas as esferas da produção habitacional, incluído a questão da terra. Muitos terrenos estatais foram destinados ao programa, como terrenos militares (Fuerte Tiuna) e do Metrô de Caracas.

No dia do lançamento do programa GMVV, Hugo Chávez realizou longo discurso sobre o tema, iniciando pela questão da terra, e finalizando com o tema do socialismo, percurso narrativo comum em seus discursos.

"Los terrenos aquí no había terrenos, los terrenos, o venían unos privados y nos vendían el terreno, nos querían vender el terreno a un costo elevadísimo que hacía inviable la construcción de vivienda o nos ponía un techo muy bajo, porque no había dinero suficiente para pagar tanto por unos terrenos que no valen eso en verdad, es especulación de los terrenos. Por eso la ley esta, la ley de ocupar terrenos, rescatar

\footnotetext{
${ }^{42} 365$ días de la Gran Misión Vivienda Venezuela. PROVEA, 2012.
} 
terreno y nosotros hacemos el avalúo con una fórmula justa y pagamos lo que de verdad valga no lo que diga el llamado mercado especulativo este, que quiere cobrar el metro cuadrado a no sé cuántos miles y miles de bolívares, no. ¡Ah! ahora nosotros estamos dando el ejemplo, poniendo terrenos que están en manos del Estado que estaban subutilizados como estos o como los del Fuerte Tiuna, ahí nadie va a pagar un centavo por ese terreno, es un terreno del Estado es decir del pueblo o lo que tenía Pdvsa eso no cuesta nada en bolívares, tiene valor de uso, no valor de cambio no es mercancía y esa es otra de las grandes diferencias del capitalismo que todo lo convierte en mercancía, un metro cuadrado, un bloque, eso es dinero, dinero, dinero y dinero, hasta el ser humano termina siendo una mercancía, los trabajadores que terminan alienados, comprados, esclavizados, explotados por el capitalista".

Se formaram na Venezuela grupos de defesa da propriedade privada, como o Observatório de Defensa de la Propiedad e o Movimiento 115 (em alusão ao artigo da Constituição que garante o uso e desfrute da propriedade privada ${ }^{43)}$.

O Observatório é uma organização vinculada a grandes e poderosos grupos empresarias da Venezuela, reunidos em torno de organizações como o Consecomercio, Grupo Roraima e CEDICE Libertad (Centro de Divulgación del Conocimiento Económico para la Libertad) (Fermín, 2007). O CEDICE está à frente do programa País de Propietarios, que tem como objetivo "contribuir con la defensa del derecho a la propiedad a través de una mejor comprensión de su estado actual, documentando, monitoreando, analizando y sistematizando información sobre violaciones a la propiedad privada a través de : El uso de vías de hecho por parte del Ejecutivo, La aprobación de leyes contrarias al artículo 115 de la CRBV e Invasiones y tomas de inmuebles realizadas por particulares". Segundo a Relial (Red Liberal de America Latina), a CEDICE Libertad ocupa o primeiro lugar entre os centros de estudos de livre mercado mais influentes da América Latina ${ }^{44}$.

\footnotetext{
${ }^{43}$ Artículo 115 da Constitución Bolivariana de Venezuela: "Se garantiza el derecho de propiedad. Toda persona tiene derecho al uso, goce, disfrute y disposición de sus bienes. La propiedad estará sometida a las contribuciones, restricciones y obligaciones que establezca la ley con fines de utilidad pública o de interés general. Sólo por causa de utilidad pública o interés social, mediante sentencia firme y pago oportuno de justa indemnización, podrá ser declarada la expropiación de cualquier clase de bienes".

${ }^{44}$ http://www.relial.org/
} 


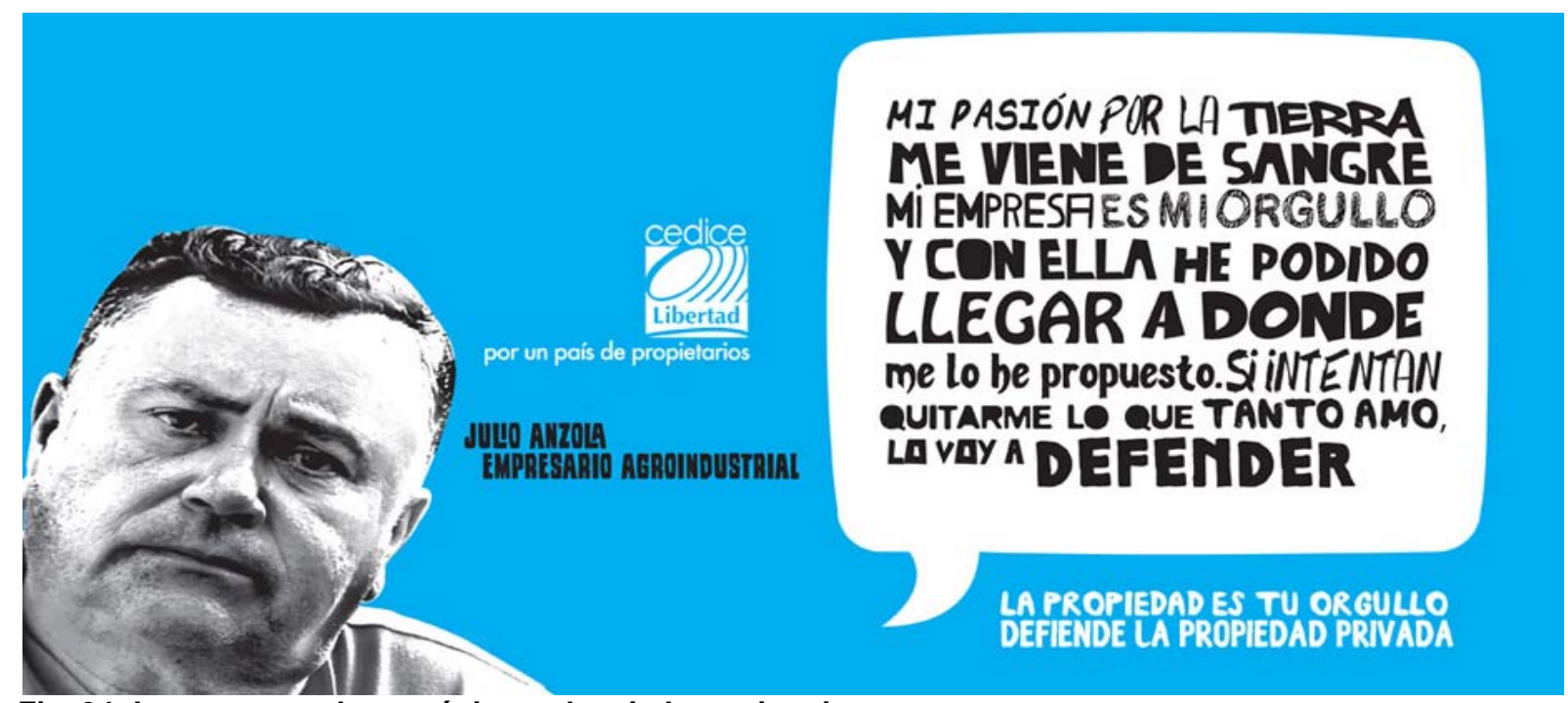

Fig. 34: Imagem que abre a página web paisdepropietarios.org

Acessado em dezembro de 2014

O último informe do Observatório é baseado no Índice de Direitos da Propriedade ${ }^{45}$, realizado por diversas instituições, entre elas o Instituto por la Libertad y la Democracia (ILD) de Hernando de Soto.

Neste ranking, entre os 97 países analisados, a Venezuela aparece na última colocação.

\section{RANKING DE PAÍSES EN EL ÍNDICE DE DERECHOS DE PROPIEDAD 2014}

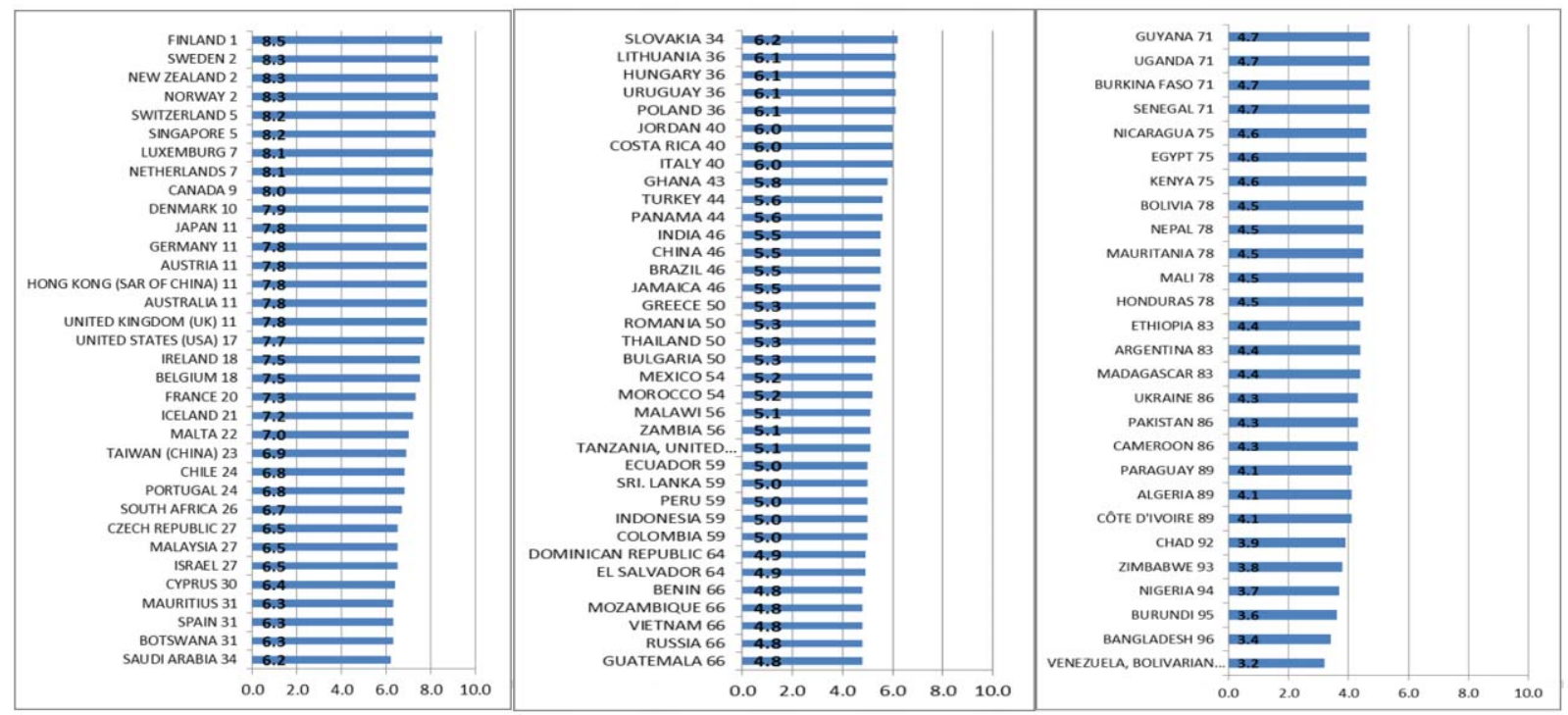

Fig. 35.

Fonte: paisdepropietarios.org

Acessado em dezembro de 2014.

\footnotetext{
${ }^{45}$ Segundo o Informe, "En líneas generales, el objetivo principal del IPRI es evaluar la consistencia del sistema de protección de los derechos de propiedad en los países (97 para la presente edición de 2014), a través del análisis de 3 componentes Y 10 variables, contenidos en el esquema 1. El IPRI incluye en su estimación no sólo el análisis de los derechos de propiedad física, sino también de los derechos de propiedad intelectual, así como el entorno político y legal de cada nación como elemento central que garantice un clima adecuado de respeto (seguridad jurídica e institucional) hacia la actividad económica y comercial de los ciudadanos. El IPRI da por estrecha la relación entre un sistema basado en los derechos de propiedad y el desempeño económico de un país, en términos de Ingreso por Hogar, Producto interno Bruto (PIB) e Inversión Extranjera Directa, como factores incidentes en la consecución de estándares de vida más elevados, aumento del ingreso per cápita, reducción de la pobreza, entre otros. La edición del IPRI 2014 incluyó un indicador novedoso, denominado "Igualdad de Género", el cual tiene por objeto valorar las condiciones de equidad existentes entre hombres y mujeres para el acceso a elementos como la tierra, el crédito, la propiedad, etc".
} 
O Movimiento 115 é constituído por pequenos e médios proprietários, afetados por expropiações não pagas pelo Estado, durante obras públicas e, mais recentemente, construção de habitação pelo programa $\mathrm{GMVV}^{46}$. Também se formou o Comité de Defensa de la Vivienda en Alquiler, composto por proprietários de imóveis que se dizem prejudicados pelos inquilinos; após a nova Lei do Inquilinato, que aumentou os direitos dos inquilinos, muitos proprietários se dizem prejudicados pelos inquilinos que, mesmo não pagando o aluguel mantêm o direito de permanecer nas casas. Tal situação levou a uma drástica redução da oferta de imóveis para locação na Venezuela, hoje praticamente nula.

\subsection{Insumos e Materiais de Construção}

Quanto aos materiais de construção, o governo se propõe a participar da produção (via empresas nacionalizadas de cimento e siderúrgicas nacionais), assim como de sua distribuição. O setor público conta com as seguintes usinas de cimento:

- Fábrica Nacional de Cemento (FNC)-Planta Táchira, Estado Táchira.

- FNC-Planta Ocumare, Estado Miranda.

- Industria Venezolana de Cemento (Invecem)-Planta Cumarebo, Estado Falcón.

- Invecem-Planta San Sebastián de Los Reyes, Estado Carabobo.

- Cemento Andino-Planta La Ceiba, Estado Trujillo.

- Venezolana de Cementos (Vencemos)-Planta Mara, Estado Zulia.

- Vencemos-Planta Pertigalete, Estado Anzoátegui.

- Planta de Cemento Cerro Azul (Monagas) (previsão).

Quanto ao setor privado, há apenas uma usina, localizada no Estado de Zulia. As empresas Holcim, Lafarge e Cemex foram declaradas de utilidade pública e nacionalizadas.

Quanto à distribuição de materiais de construção, o governo montou os chamados Construpatria, centros de distribuição de materiais para o programa habitacional.

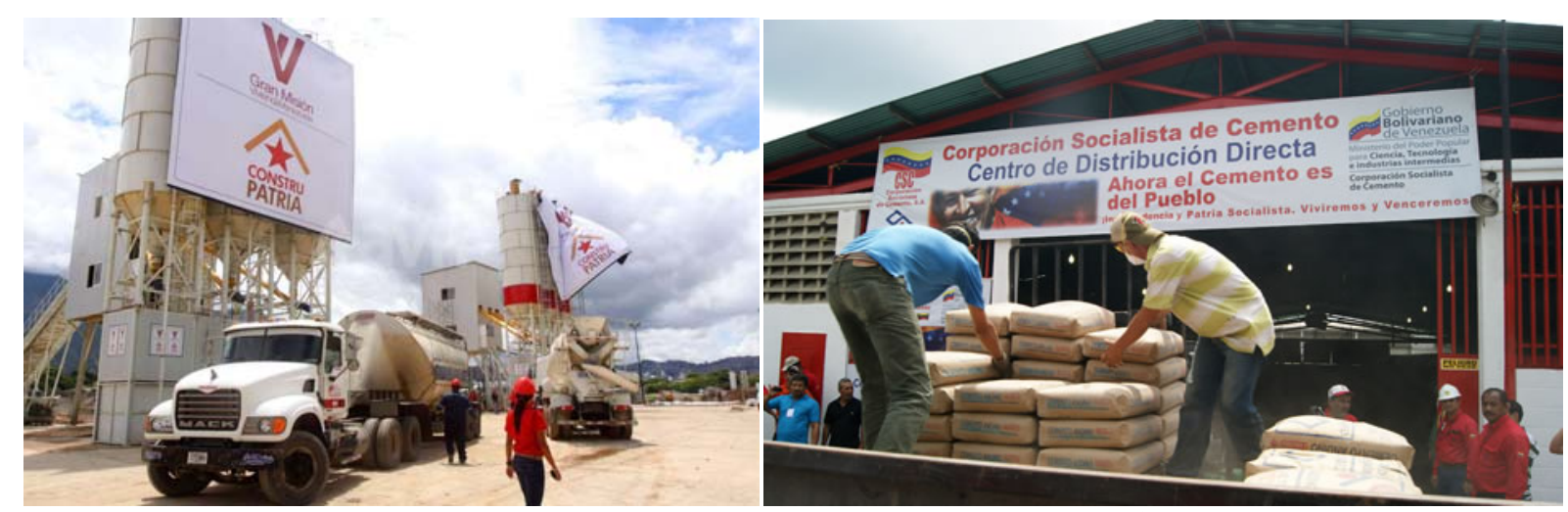

Fig. 36: Construpatria; Fig. 37: Centro de distribuição de cimento da Corporación Socialista de Cemento. Fonte: Site do GMVV (www.misionvivienda.gov.ve) acessado em junho de 2013.

\footnotetext{
${ }^{46}$ Crearon Grupo em Defensa de la Propiedad. El Nacional de 18 de setembro de 2013. www.el-nacional.com acessado em dezembro de 2014.
} 


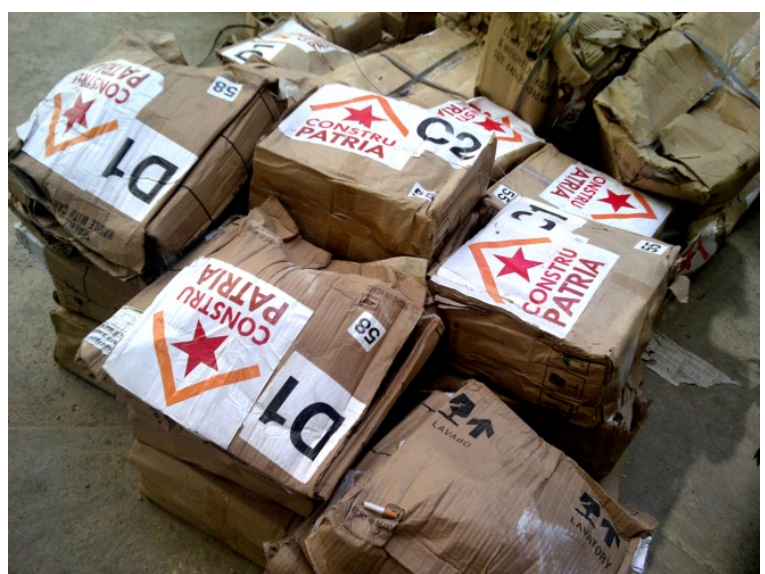

Fig. 38: Materiais Construpatria na Nueva Comunidad Socialista Kaika-Shi. Foto do autor.

Até 2014 os centros Construpatria haviam distribuído armarção para o equivalente a 853.933 habitações e cimento para 301.572 .

Atualmente existem 52 centros Construpatria pelo país distribuídos em 24 estados.

\subsection{Executores}

Quanto ao vértice relativo aos Executores, a política venezuelana considera os diversos entes nacionais (Companhia de Metrô, Oficina de Proyectos y Planes Especiales, entre outros), as comunidades organizadas, os convênios internacionais, os entes estatais e municipais e as empresas privadas. A participação de cada um no total de habitações construídas é a seguinte:

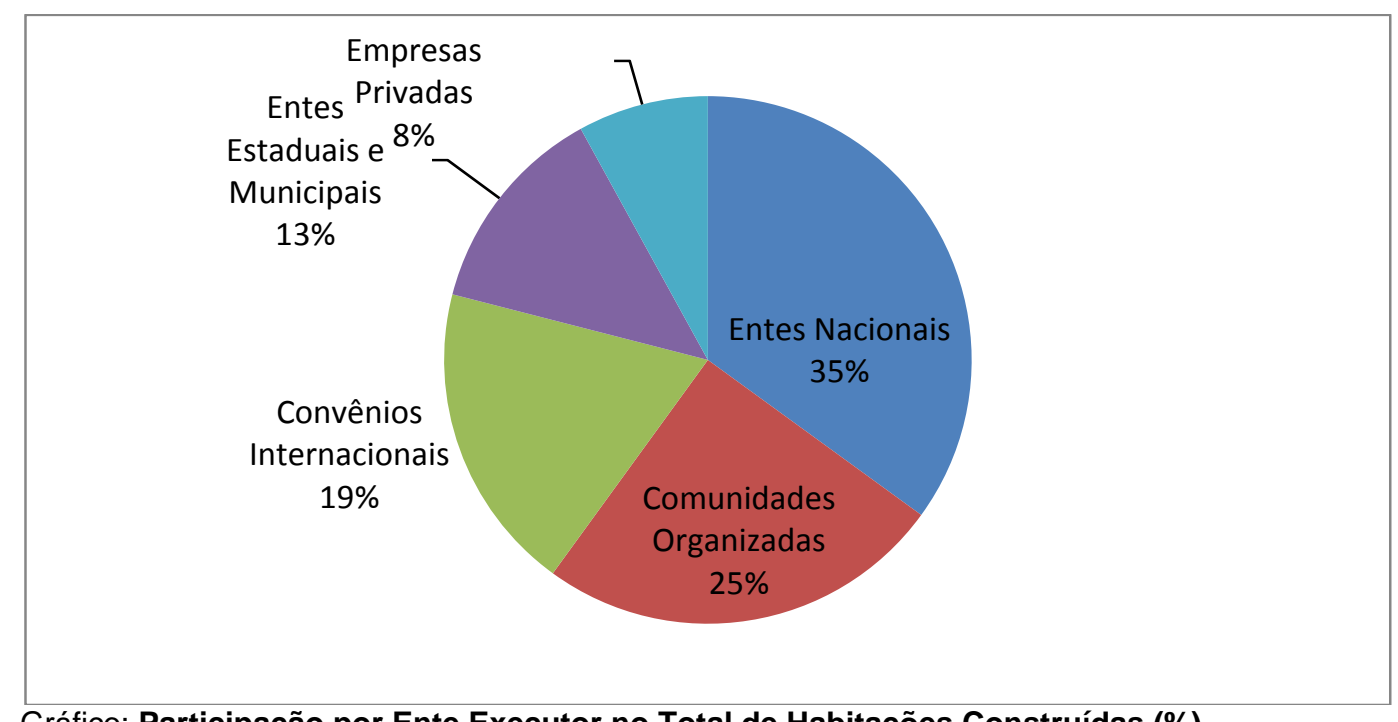

Gráfico: Participação por Ente Executor no Total de Habitações Construídas (\%).

FONTE: Site do GMVV (www.misionvivienda.gov.ve) acessado em junho de 2013. 


\begin{tabular}{|c|c|c|c|}
\hline \multirow{2}{*}{ Ente Executor (por grupos) } & \multicolumn{3}{|c|}{ Unidades a executar } \\
\hline & 2011 & 2012 & 2011-2012 \\
\hline Governo Nacional & 69.745 & 56.001 & 125.746 \\
\hline Comunidades Organizadas & 49.171 & 40.324 & 89.495 \\
\hline Convênios Internacionais & 10.307 & 54.536 & 64.843 \\
\hline Governos Estaduais e Municipais & 13.423 & 33.053 & 46.476 \\
\hline Empresas Privadas & 8.779 & 18.965 & 27.744 \\
\hline Habitações entregues ENE-FEB & 1.725 & & \\
\hline TOTAL & 153.150 & 202.879 & 354.304 \\
\hline
\end{tabular}

\section{Convênios Internacionais}

Os convênios internacionais estão produzindo gigantescos conjuntos habitacionais, normalmente em regiões afastadas da cidade. Os convênios foram firmados com parceiros internacionais que mantém relações estreitas com o atual governo, e se evidencia a tendência de alinhamento a países que possibilitem alternativas econômicas e políticas em relação aos Estados Unidos da América, como China, Irã, Bielorússia, Cuba, Turquia, e Rússia.

As obras são realizadas normalmente com tecnologia importada do país conveniado, nem sempre bem aceitas pela comunidade local. A preocupação com a proposta quantativa é evidente, e o resultado enquanto desenho arquitetônico e urbano tem sido bastante pobre. No entanto, é necessário ressaltar que, em todos os casos, se mantém a preocupação de dedicar espaços a projetos sócio-produtivos, empresas comunitárias, escolas, etc. 


\begin{tabular}{|c|c|c|c|}
\hline Pais & Empresa & Meta & Ubicación \\
\hline Belarús & $\begin{array}{l}\text { BZS } \\
\text { Belzarubezhstroy }\end{array}$ & 10.000 viviendas & $\begin{array}{l}\text { Fuerte Tiuna, Municipio Libertador del Distrito } \\
\text { Capital; Guarenas, Municipio Plaza y Guatire } \\
\text { Municipio Zamora ambas en el estado Miranda. }\end{array}$ \\
\hline Belarús & $\begin{array}{l}\text { BZS } \\
\text { Belzarubezhstroy }\end{array}$ & 3.000 viviendas & $\begin{array}{l}\text { sectores de Santa Inés y la Zona Industrial de la } \\
\text { Ciudad de Barinas, estado Barinas. }\end{array}$ \\
\hline Belarús & $\begin{array}{l}\text { BZS } \\
\text { Belzarubezhstroy }\end{array}$ & 4.448 viviendas & $\begin{array}{l}\text { Base Aérea Libertador, Palo Negro, Maracay. } \\
\text { (Addendum) }\end{array}$ \\
\hline Belarús & $\mathrm{S} / \mathrm{I}$ & 2.540 viviendas & $\begin{array}{l}\text { Proyecto Guasimal, Municipio Girardot del } \\
\text { estado Aragua. }\end{array}$ \\
\hline China & $\begin{array}{l}\text { CITIC International } \\
\text { Contracting }\end{array}$ & 13.034 viviendas & $\begin{array}{l}\text { Fuerte Tiuna, Municipio Libertador del Distrito } \\
\text { Capital }\end{array}$ \\
\hline China & $\mathrm{S} / \mathrm{I}$ & 20.000 viviendas & $\begin{array}{l}\text { 7.376 viviendas en las locaciones de El Arsenal } \\
\text { y Palmasola; } 2.220 \text { viviendas en la locación de } \\
\text { Marizapa, en Caucagua, estado Miranda, donde } \\
\text { se está dando inicio a la nueva Ciudad } \\
\text { Caucagua; igualmente en los terrenos de la } \\
\text { Hacienda La Mora, en la ciudad de La Victoria, } \\
\text { estado Aragua, se dio inicio a la construcción de } \\
1.800 \text { nuevas viviendas. } 5.360 \text { viviendas que se } \\
\text { ejecutan en la locación de Palmasola, en la } \\
\text { ciudad de Barinas, Edo. Barinas. }\end{array}$ \\
\hline Irán & Kayson Company & $\begin{array}{l}10.008 \text { unidades de } \\
\text { vivienda }\end{array}$ & $\begin{array}{l}\text { Yucatán, Municipio Iribarren del Estado Lara } \\
\text { ( } 4.464 \text { viviendas), Comunivares, Municipio San } \\
\text { Felipe del Estado Yaracuy ( } 2.520 \text { viviendas), y } \\
\text { finalmente } \\
\text { Ciudad Ambrosio Plaza, Municipio Valencia } \\
\text { del Estado Carabobo (3.024 viviendas). }\end{array}$ \\
\hline Irán & Kayson Company & $\begin{array}{l}7.000 \text { unidades de } \\
\text { vivienda }\end{array}$ & $\begin{array}{l}\text { sector Ciudad Caribia, } \\
\text { en el Municipio Libertador del Dtto. Capital. } \\
\text { Como parte del gran proyecto Ciudad Caribia. }\end{array}$ \\
\hline $\begin{array}{l}\text { Federación } \\
\text { Rusa }\end{array}$ & $\mathrm{N} / \mathrm{I}$ & $\begin{array}{l}10.000 \text { unidades de } \\
\text { vivienda }\end{array}$ & $\begin{array}{l}\text { sector de Fuerte Tiuna, Municipio Libertador } \\
\text { del Distrito Capital. }\end{array}$ \\
\hline Portugal & $\mathrm{N} / \mathrm{I}$ & $\begin{array}{l}12.512 \text { unidades de } \\
\text { vivienda }\end{array}$ & $\begin{array}{l}\text { "tres locaciones de los Valles del Tuy, Estado } \\
\text { Miranda" }\end{array}$ \\
\hline Turquía & SUMMA & $\begin{array}{l}1.488 \text { unidades de } \\
\text { vivienda }\end{array}$ & $\begin{array}{l}\text { sector Playa Grande, en el Municipio Vargas del } \\
\text { Estado Vargas }\end{array}$ \\
\hline $\begin{array}{l}\text { Reino de } \\
\text { España }\end{array}$ & Essentium & $\begin{array}{l}3.264 \text { unidades de } \\
\text { vivienda }\end{array}$ & $\begin{array}{l}\text { sector denominado El Triplex, Santa Teresa del } \\
\text { Tuy, Municipio } \\
\text { Independencia del Estado Miranda. }\end{array}$ \\
\hline $\begin{array}{l}\text { República } \\
\text { Federativa } \\
\text { de Brasil: }\end{array}$ & $\mathrm{S} / \mathrm{I}$ & ¿486 viviendas? & $\begin{array}{l}\text { Polo Urbano de Desarrollo Endógeno "Fuerte } \\
\text { Cayaurima", ubicado en Ciudad Bolivar, } \\
\text { Municipio Heres del estado Bolivar }\end{array}$ \\
\hline $\begin{array}{l}\text { República } \\
\text { de } \\
\text { Uruguay }\end{array}$ & $\mathrm{S} / \mathrm{I}$ & $\begin{array}{l}8.110 \mathrm{Kits} \text { de } \\
\text { viviendas }\end{array}$ & $\begin{array}{l}\text { Anzoátegui, Aragua, Bolívar, Delta Amacuro, } \\
\text { Guarico, Apure, Nueva Esparta, Trujillo, } \\
\text { Mérida, Amazonas, Cojedes, Zulia, y en las } \\
\text { localidades de Los Roques y La Orchila }\end{array}$ \\
\hline
\end{tabular}

Información: Memoria y Cuenta 2011 del Ministerio del Poder Popular para la Vivienda y Hábitat 


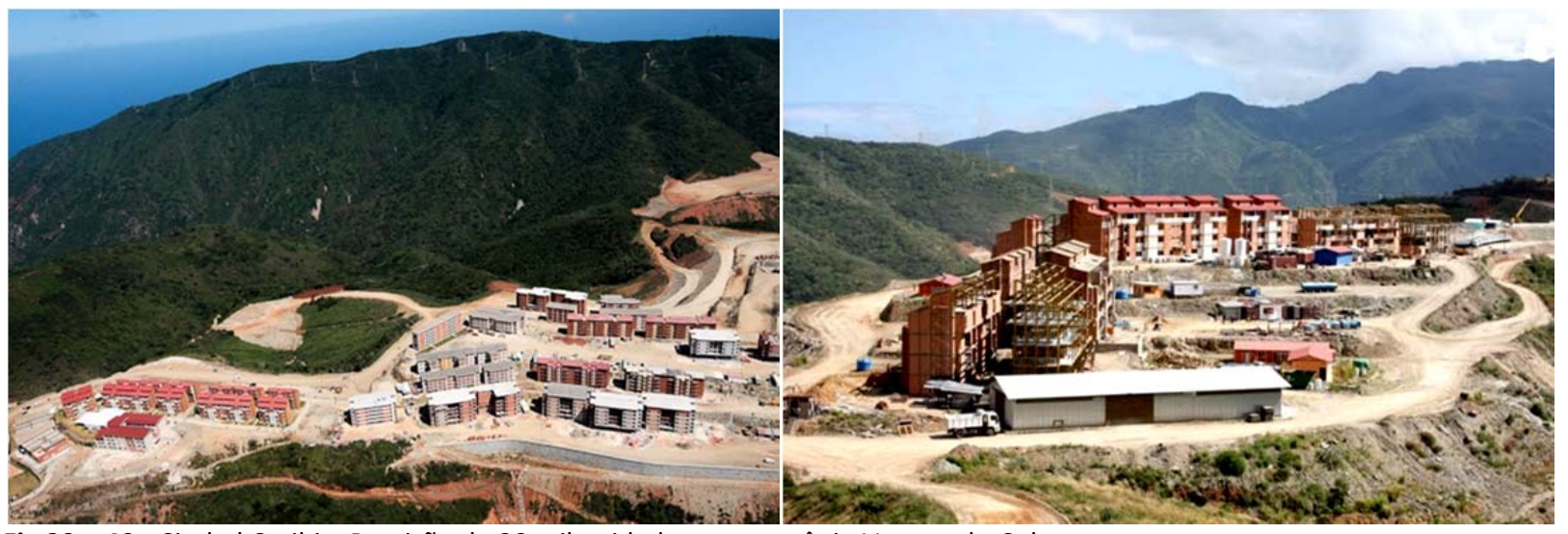

Fig 39 e 40.: Ciudad Caribia. Previsão de 20 mil unidades em convênio Venezuela-Cuba.

Fonte: Site do GMVV (www.misionvivienda.gov.ve) acessado em junho de 2013.
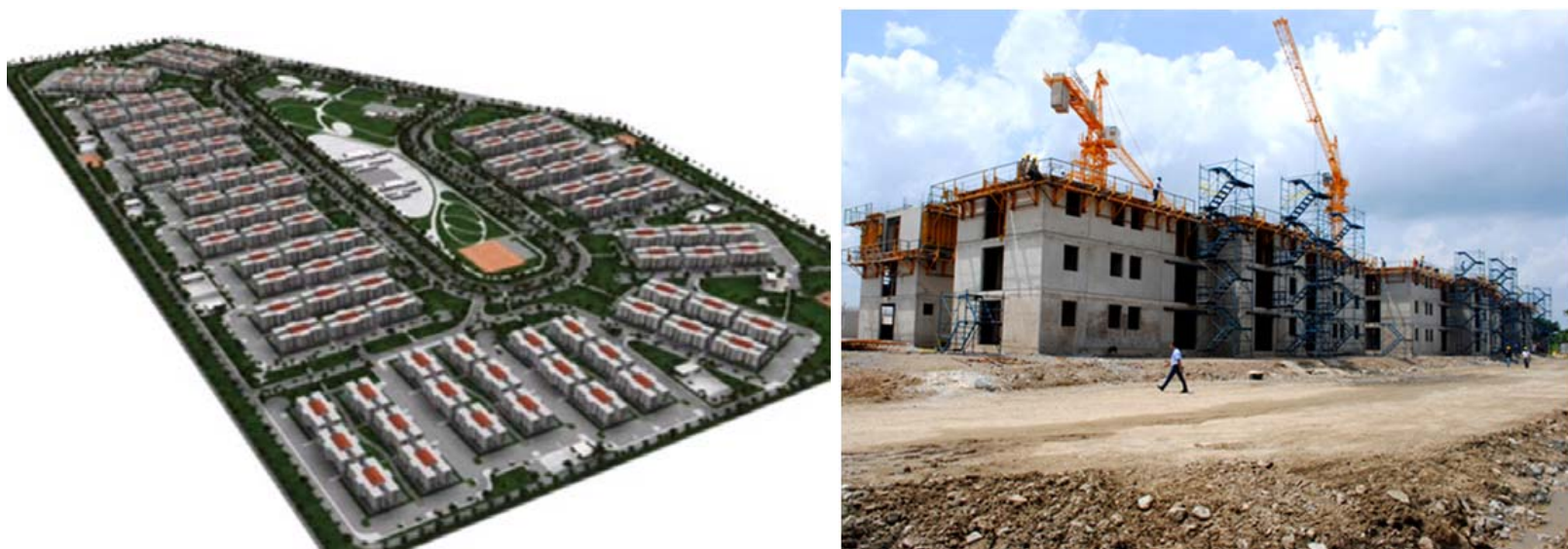

Fig 41: Convênio com Irã; Fonte: Site do GMVV (www.misionvivienda.gov.ve) acessado em junho de 2013.

Fig 42: Convênio com Irã; Fonte: Site Noticias 24 (www.noticias24.com) acessado em dezembro de 2014.

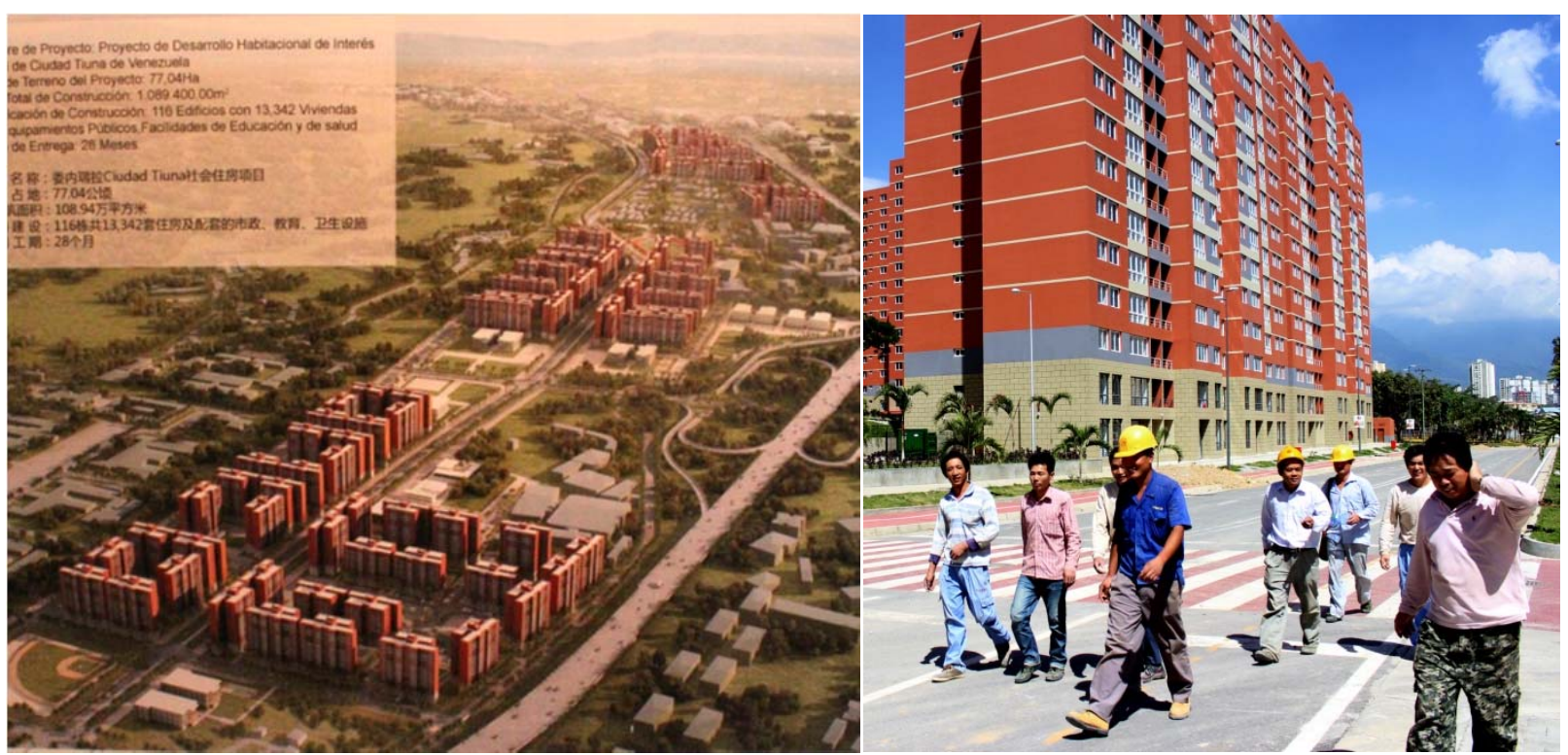

Fig. 43: Maquete eletrênica da Ciudad Tiuna. Fonte: Exposição GMVV no Museo de Arquitectura de Caracas.

Fig. 44: Operários chineses na Ciudad Tiuna - convênio chinês. Foto do autor. 


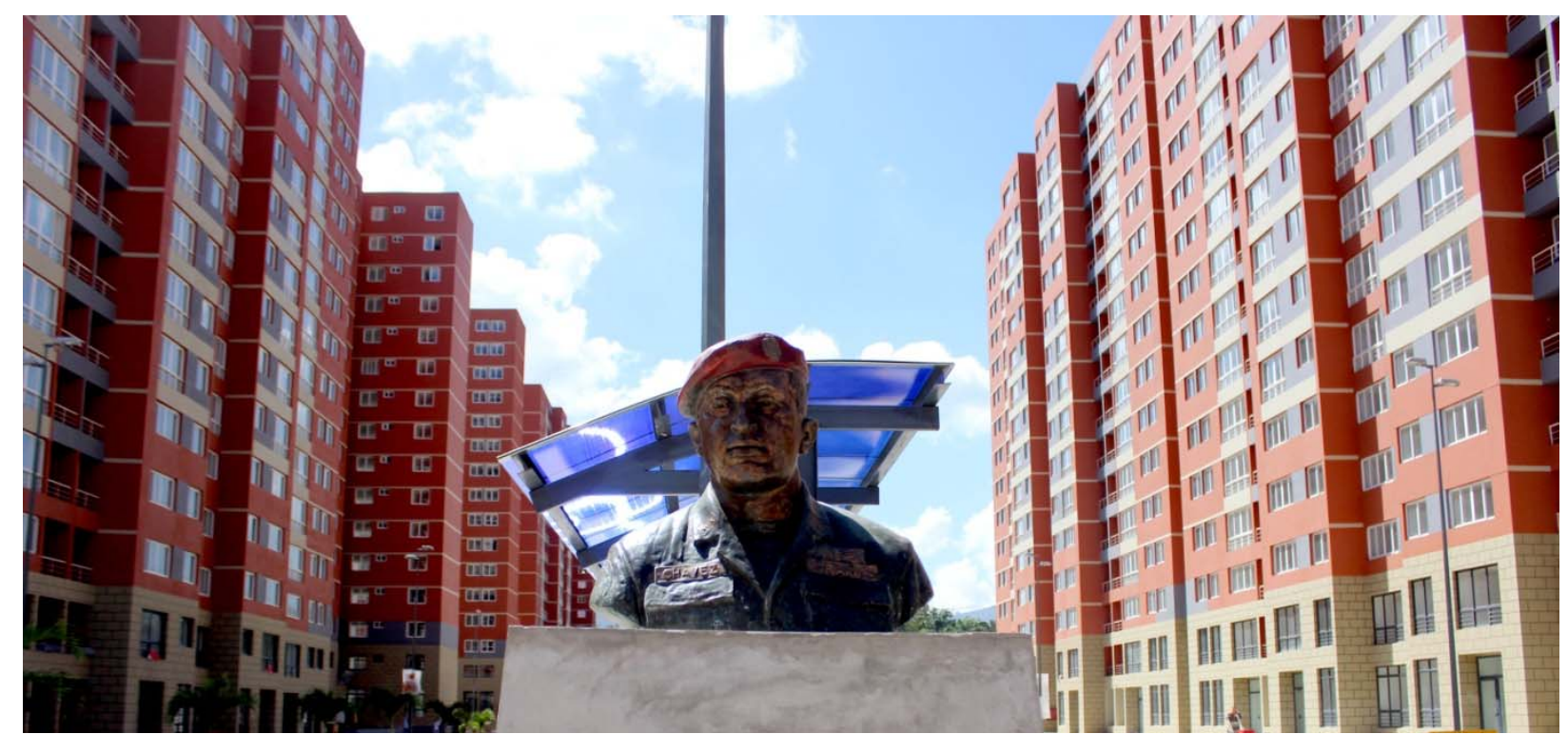

Fig 45: Busto de Hugo Chávez, Ciudad Tiuna - convênio chinês. Foto do autor.
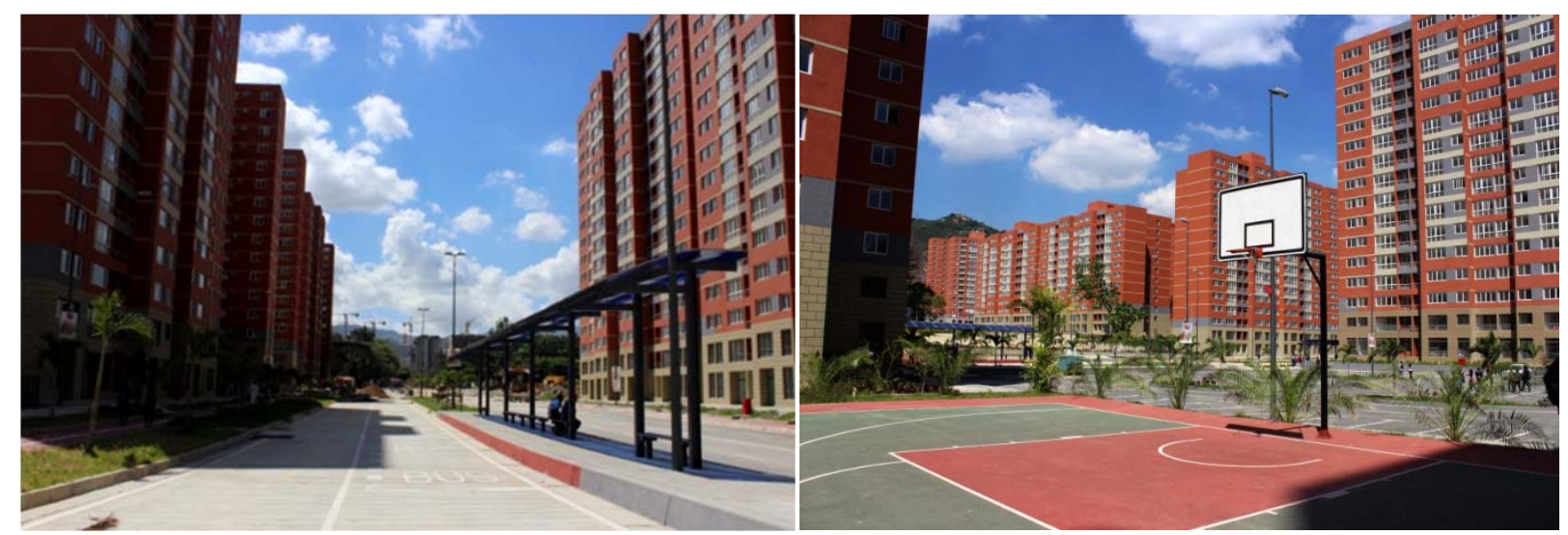

Fig 46: Ciudad Tiuna - convênio chinês. Foto do autor.

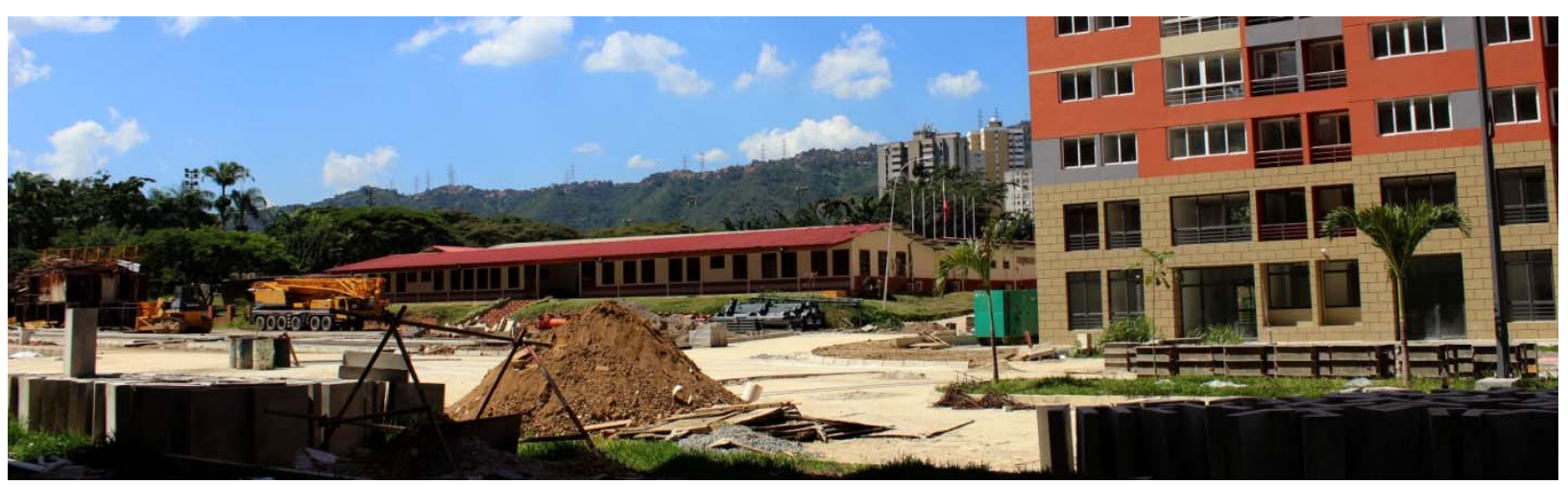

Fig 47: Escola pública em Ciudad Tiuna - convênio chinês. Foto do autor. 


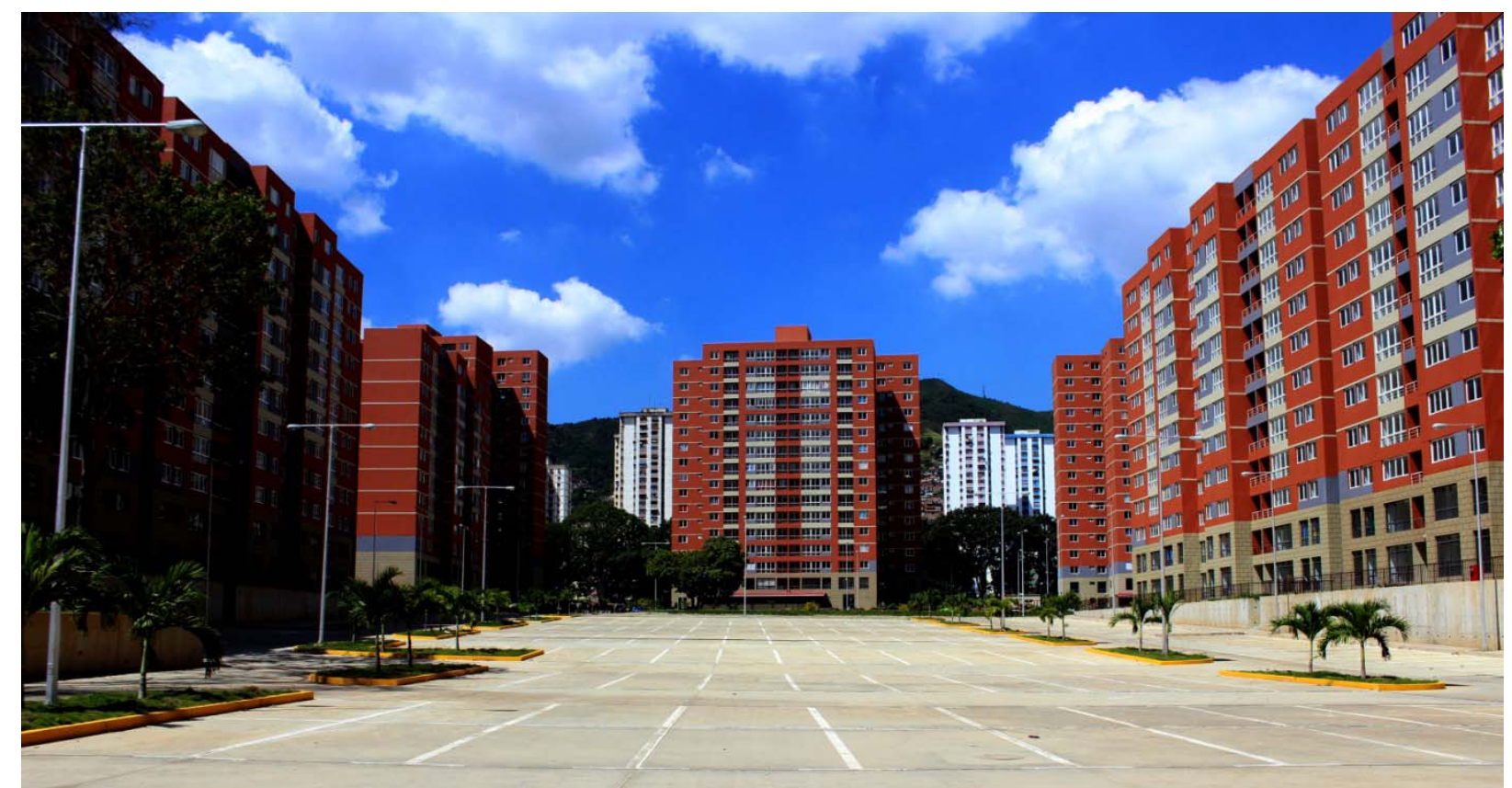

Fig 48: Ciudad Tiuna - convênio chinês. Foto do autor.

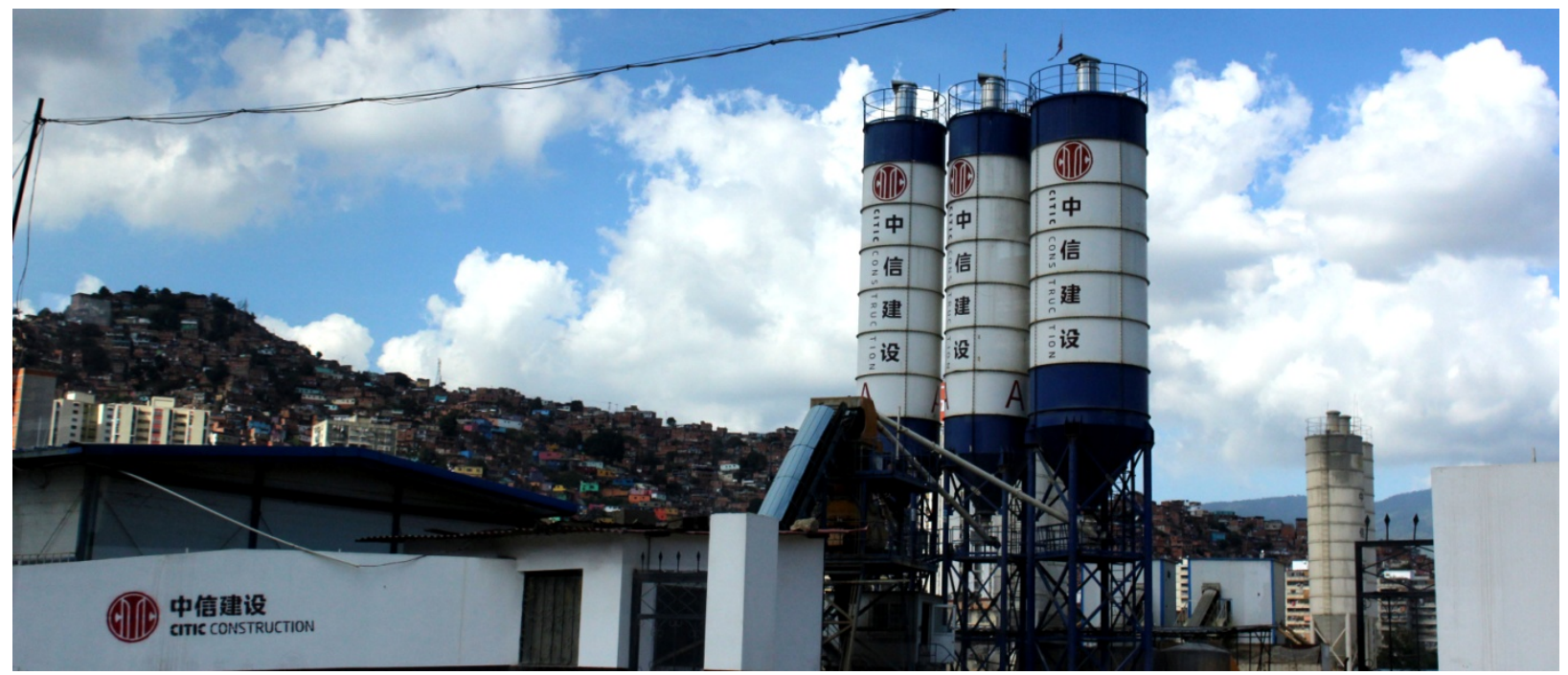

Fig. 49: Canteiro de Obras Ciudad Tiuna - convênio chinês. Foto do autor.
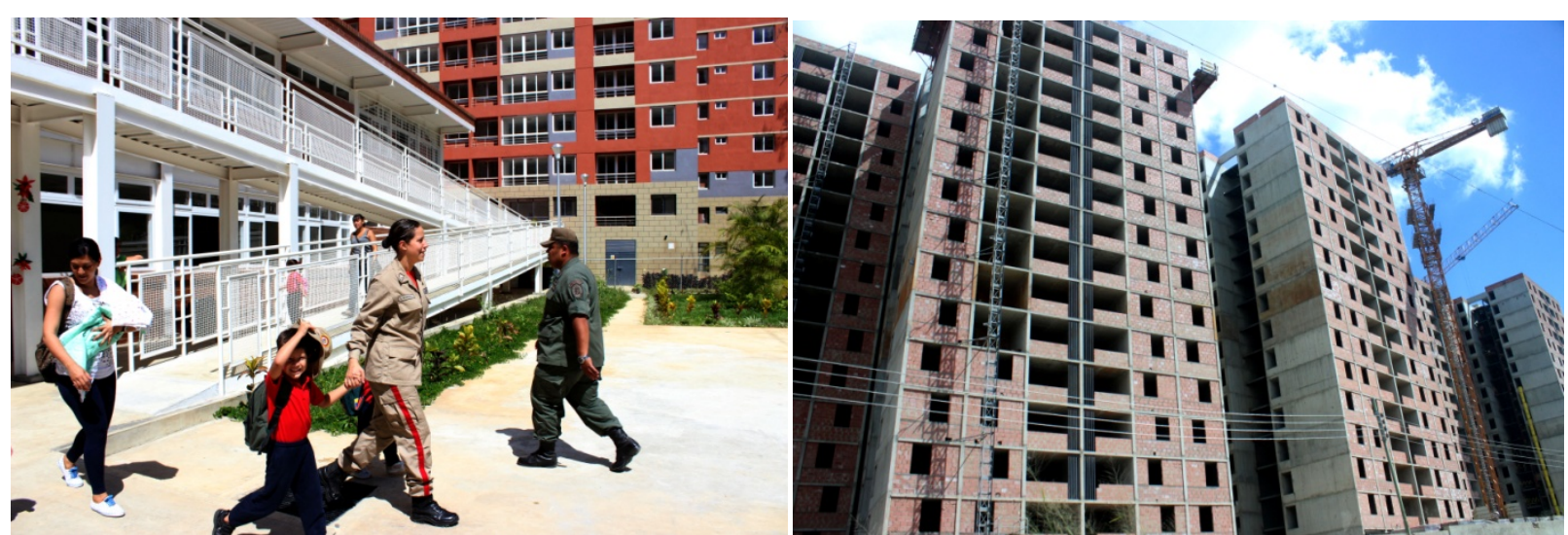

Fig 50: Escola pública, Ciudad Tiuna - convênio chinês. Fig 51: Ciudad Tiuna, convêio Bielorusso. Fotos do autor. 


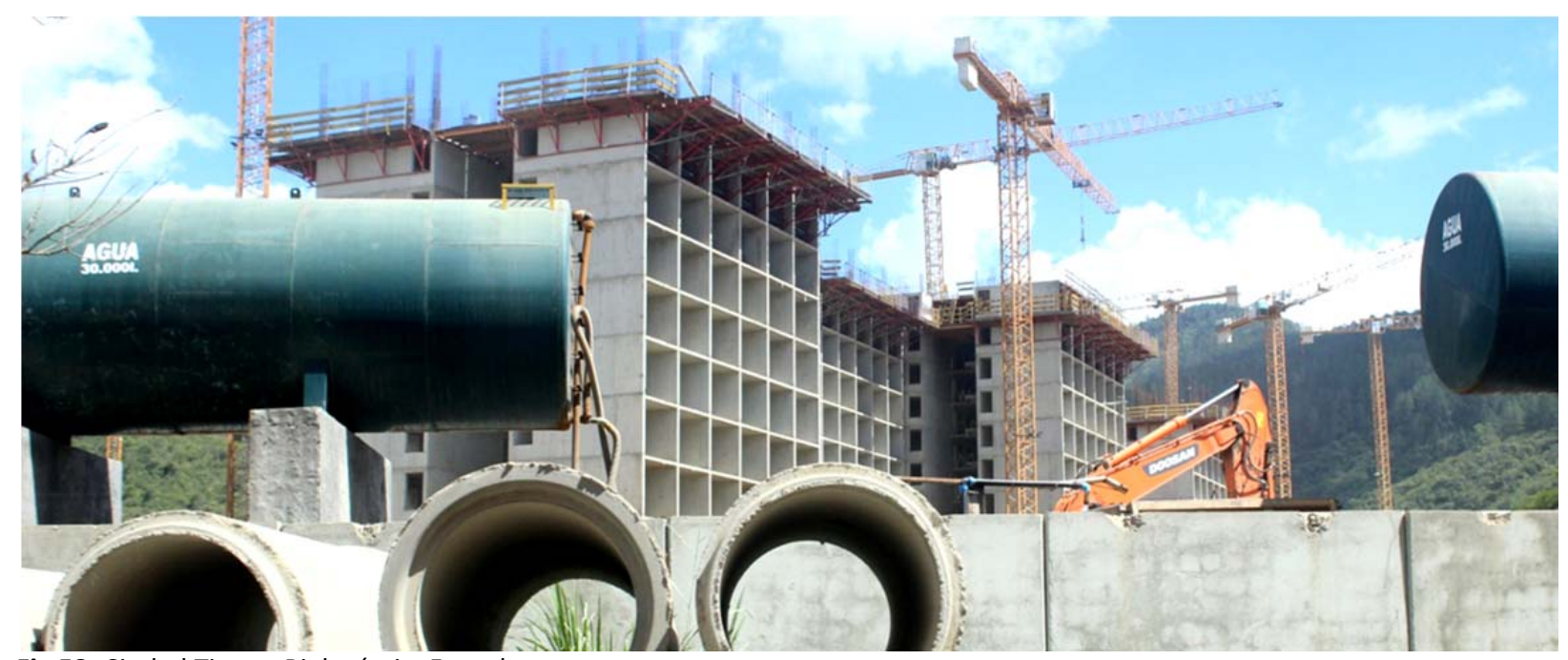

Fig 52: Ciudad Tiuna - Bielorússia. Foto do autor.

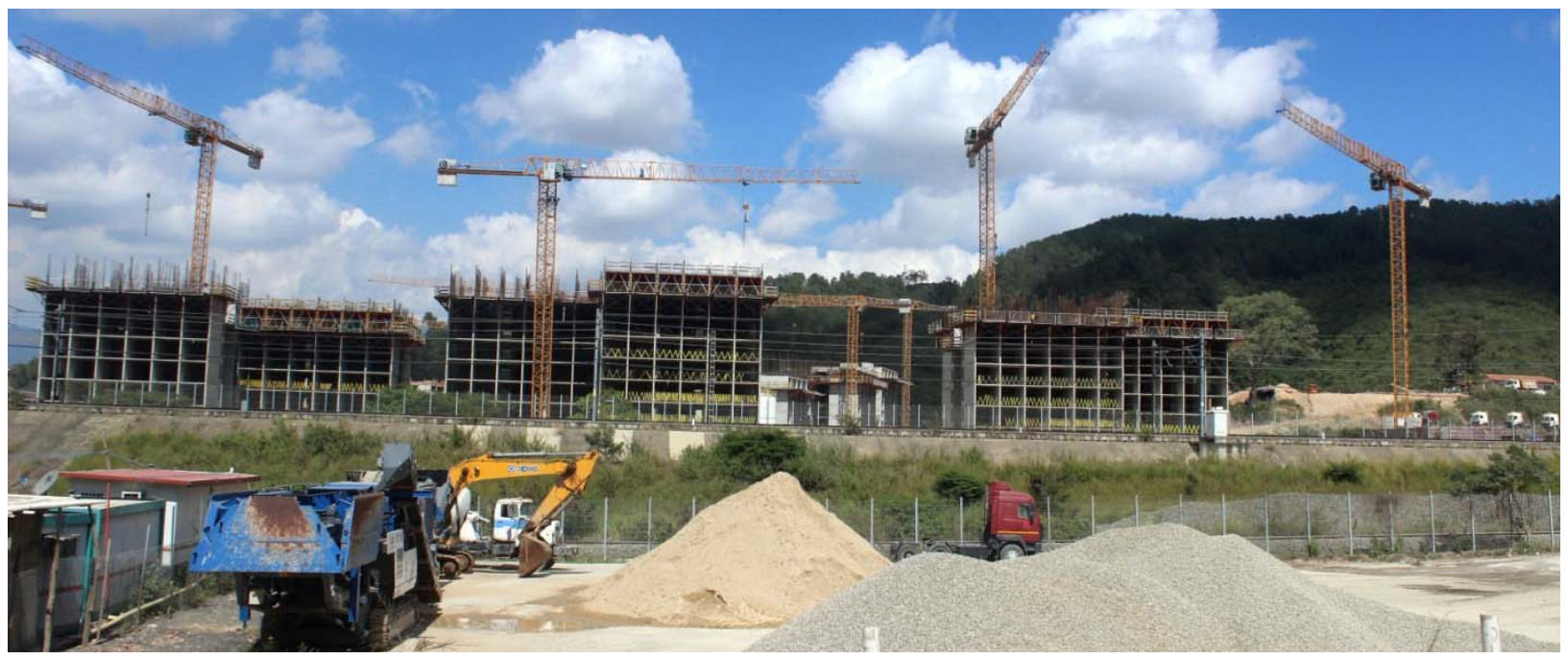

Fig 53: Ciudad Tiuna - Bielorússia. Foto do autor.

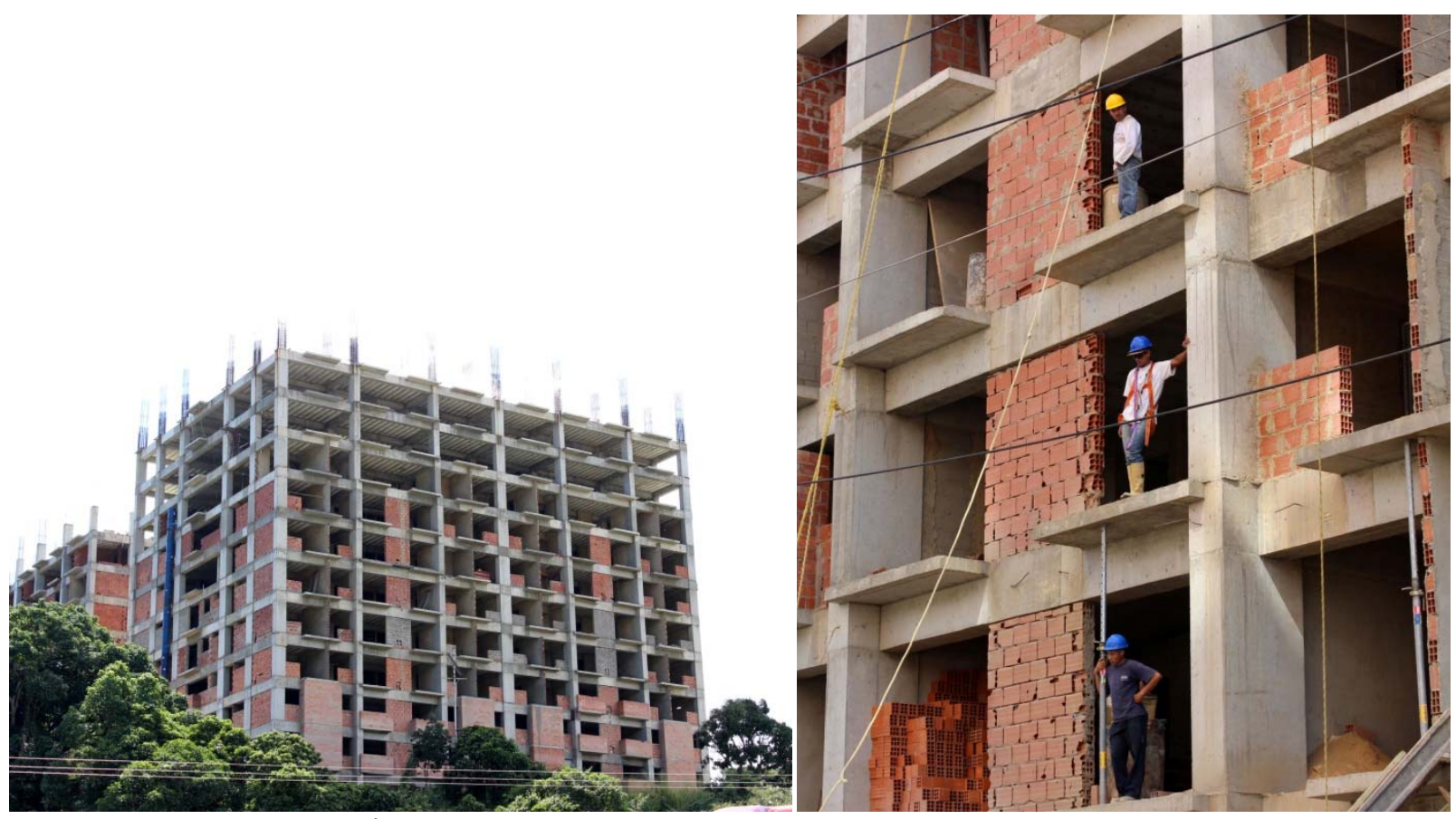

Fig 54 e 55: Ciudad Tiuna - convênio russo. Fotos do autor. 


\section{Comunidades Organizadas}

\begin{tabular}{|l|l|l|l|l|}
\hline Estado & $\begin{array}{l}\text { Nro. de } \\
\text { proyectos }\end{array}$ & $\begin{array}{l}\text { Nro. de } \\
\text { viviendas } \\
\text { a sustituir }\end{array}$ & $\begin{array}{l}\text { Monto del } \\
\text { proyecto } \\
\text { (en Bs.) }\end{array}$ & $\begin{array}{l}\text { Inversión } \\
\text { por vivienda } \\
\text { (en Bs.) }\end{array}$ \\
\hline Amazonas & 122 & 835 & $95.372 .132,00$ & $114.218,12$ \\
\hline Anzoátegui & 152 & 2131 & $222.835 .156,00$ & $104.568,35$ \\
\hline Aragua & 134 & 1673 & $236.699 .270,00$ & $141.481,93$ \\
\hline Apure & 173 & 2833 & $185.541 .785,00$ & $65.493,04$ \\
\hline Barinas & 375 & 1954 & $221.543,572,00$ & $113.379,51$ \\
\hline Bolívar & 213 & 1312 & $146.801 .041,00$ & $111.891,04$ \\
\hline Carabobo & 262 & 2219 & $252.019 .968,00$ & $113.573,67$ \\
\hline Cojedes & 288 & 1422 & $182.097 .172,00$ & $128.057,08$ \\
\hline Delta Amacuro & 108 & 1642 & $156.588 .379,00$ & $95.364,42$ \\
\hline Distrito Capital & 160 & 627 & $57.613 .705,00$ & $91.887,89$ \\
\hline Falcón & 510 & 3121 & $311.204 .622,00$ & $99.713,11$ \\
\hline Guárico & 319 & 1637 & $201.279 .776,00$ & $122.956,49$ \\
\hline Lara & 482 & 1328 & $219.606 .131,00$ & $165.366,06$ \\
\hline Mérida & 228 & 1370 & $154.154 .789,00$ & $112.521,74$ \\
\hline Miranda & 221 & 2271 & $187.057 .400,00$ & $82.367,86$ \\
\hline Monagas & 154 & 1452 & $151.867 .398,00$ & $104.591,87$ \\
\hline Nueva Esparta & 180 & 572 & $90.809 .380,00$ & $158.757,66$ \\
\hline Portuguesa & 503 & 2061 & $234.042 .498,00$ & $113.557,74$ \\
\hline Sucre & 145 & 1773 & $185.056 .899,00$ & $104.375,01$ \\
\hline Táchira & 160 & 2578 & $258.979 .259,00$ & $100.457,43$ \\
\hline Trujillo & 129 & 1342 & $146.449 .785,00$ & $109.128,01$ \\
\hline Vargas & 58 & 940 & $76.320 .901,00$ & $81.192,45$ \\
\hline Yaracuy & 152 & 819 & $122.210 .155,00$ & $149.218,75$ \\
\hline Zulia & 171 & 2597 & $272.350 .131,00$ & $104.871,06$ \\
\hline Total & $\mathbf{5 3 9 9}$ & $\mathbf{4 0 5 0 9}$ & $\mathbf{2 7 2 . 3 5 0 . 1 3 1 , 0 0}$ & $\mathbf{1 1 2 . 0 4 1 , 2 6}$ \\
\hline & & & & \\
\hline
\end{tabular}

Fonte: Memoria y Cuenta, 2011.

Um dos dados que mais chama atenção nos números do GMVV é a quantidade de casas construídas pelos Conselhos Comunais, em sistema de co-gestão entre comunidade e poder público. Para a construção, são formadas brigadas de construtores.
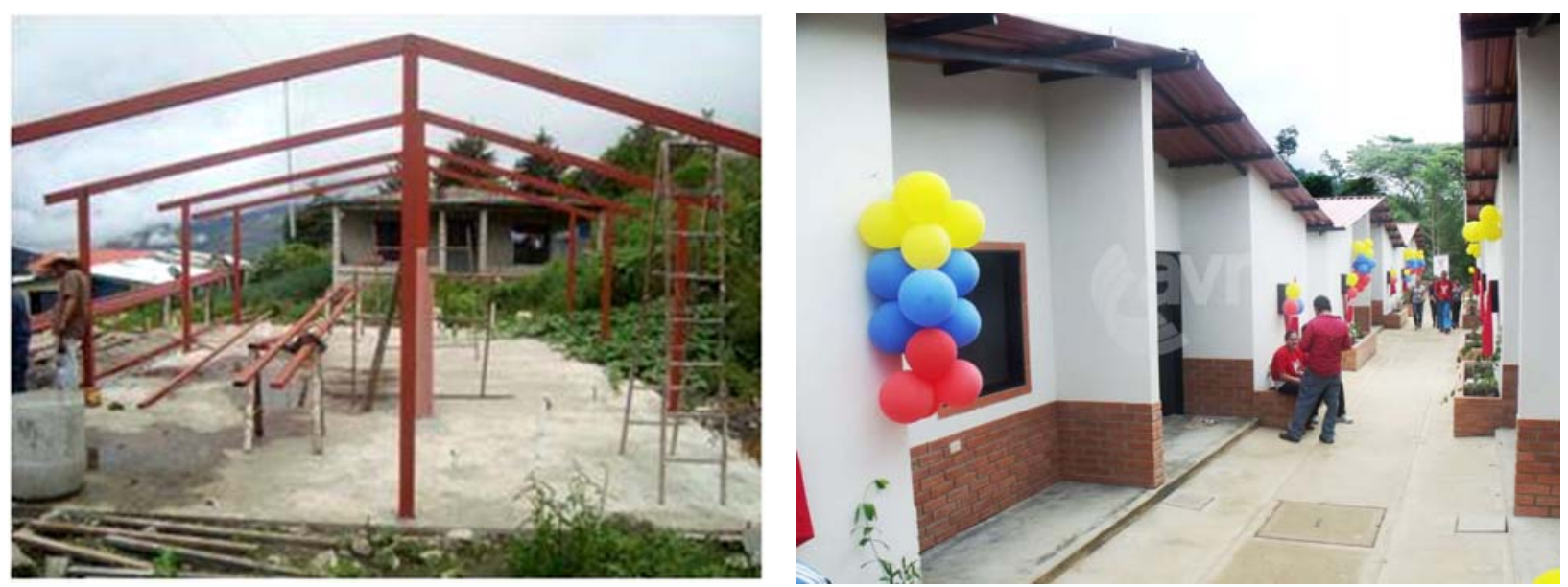

Fig. 56 e 57: Habitações construídas pelos Consejos Comunales.

A simplicidade construtiva das habitações e a estrutura pré-fabricada explicam a como foi possível a massificação da construção pelos conselhos comunais. 


\section{Localização das habitações construídas}

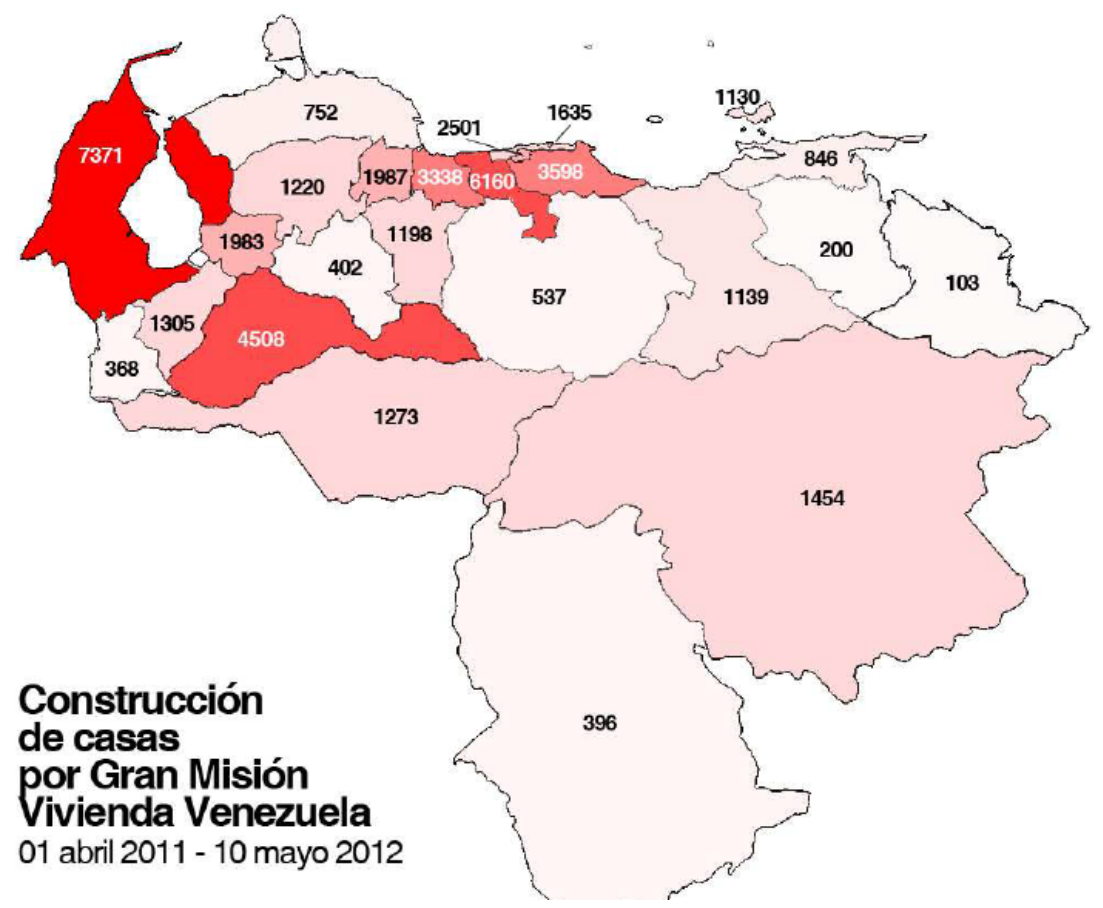

FONTE: PROVEA.

\section{Prefeituras e estados}

É extremamente heterogênea a produção por parte das esferas locais do poder público, dependentes diretamente da capacidade técnica de cada instituição. Entre as produções municipais, destacam-se os projetos realizados pela prefeitura de Caracas, que trabalha com o princípio de Proyetos Integrales de Vivienda, nos quais são articulados espaços sócio-produtivos, serviços públicos e habitação, em projetos arquitetônicos que buscam articular-se de forma diferenciada com o espaço urbano.

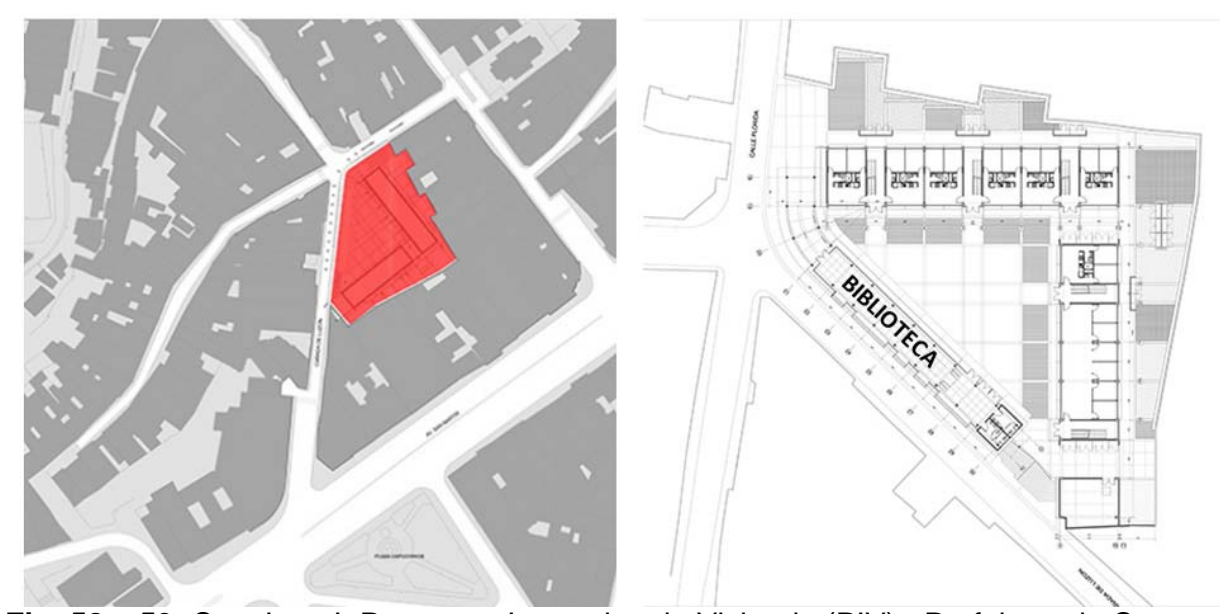

Fig. 58 e 59: San Juan I. Proyectos Integrales de Vivienda (PIV) - Prefeitura de Caracas Fonte: Site do GMVV (www.misionvivienda.gov.ve) acessado em junho de 2013. 


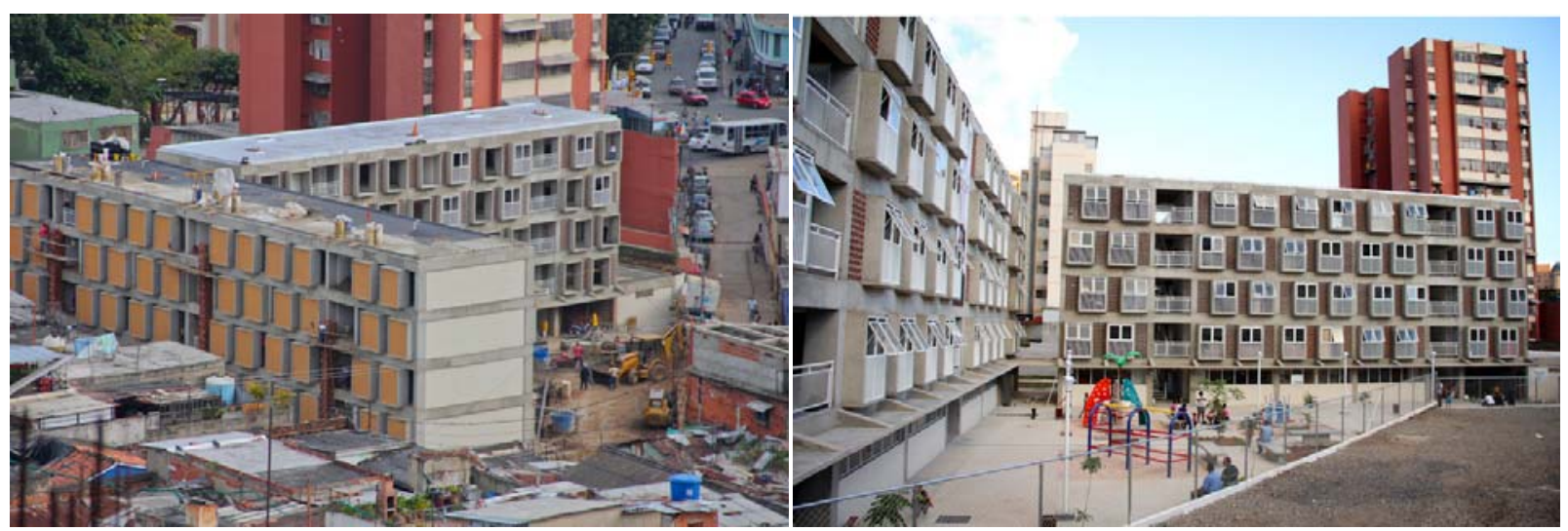

Fig. 60 e 61: San Juan I. Proyectos Integrales de Vivienda (PIV) - Prefeitura de Caracas Fonte: Site do GMVV (www.misionvivienda.gov.ve) acessado em junho de 2013.

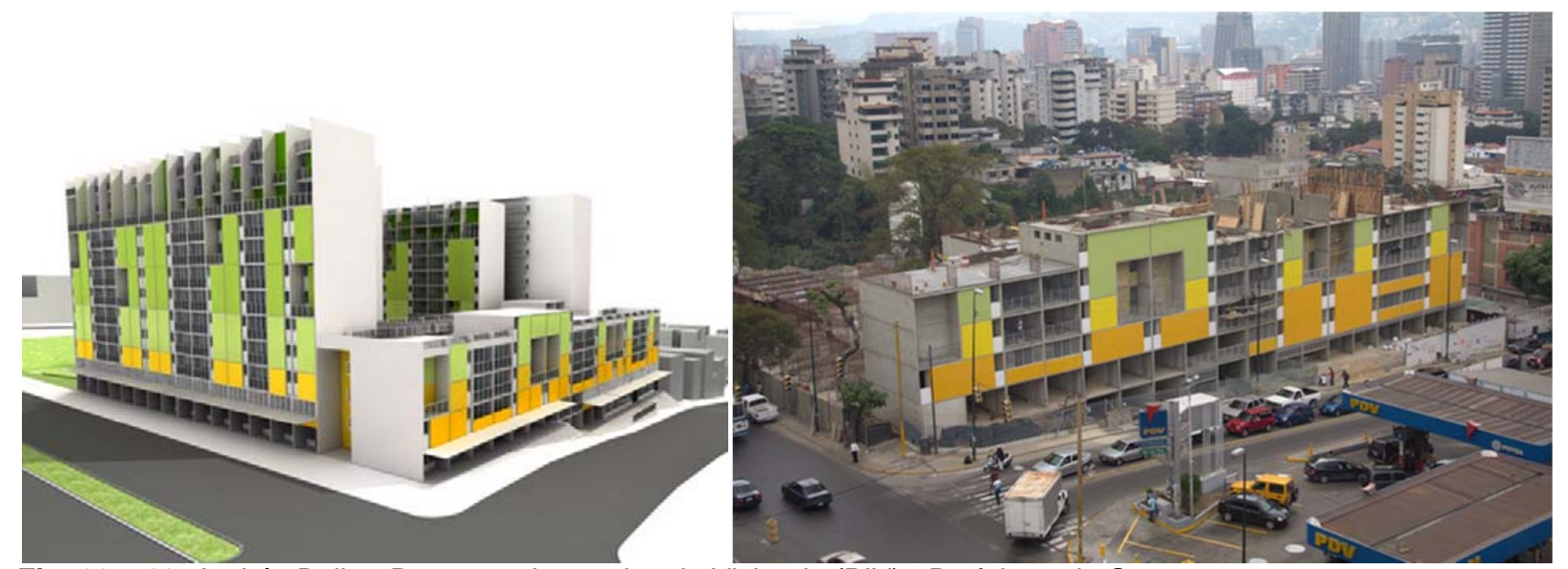

Fig. 62 e 63: Andrés Bello - Proyectos Integrales de Vivienda (PIV) - Prefeitura de Caracas. Fonte: Site do GMVV (www.misionvivienda.gov.ve) acessado em junho de 2013.

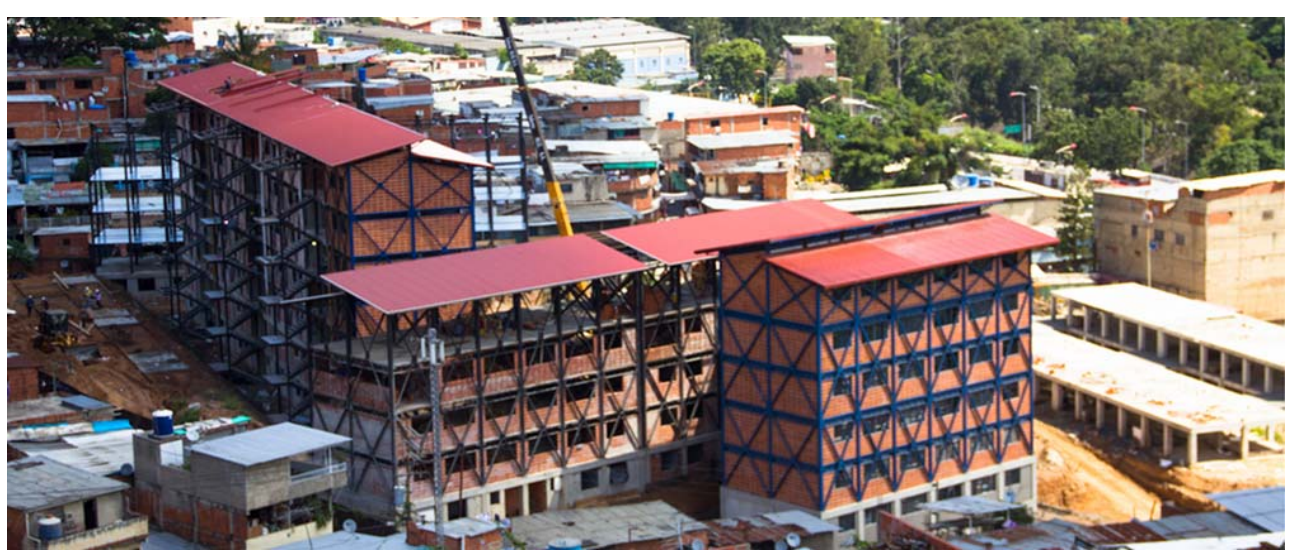

Fig. 63 e 64: Antínamo - Proyectos Integrales de Vivienda (PIV) - Prefeitura de Caracas. Fonte: Site do GMVV (www.misionvivienda.gov.ve) acessado em junho de 2013. 


\section{O Movimiento de}

\section{Pobladoras y Pobladores}

"A decadência das experiências de Vila Nova Cachoeirinha é evidente. Em pouco tempo, os elementos inovadores construídos por gerações de técnicos e integrantes da Associação de Moradia Unidos de Vila Nova Cachoeirinha terminarão de ser sufocados e vão morrer. E então - assim como aconteceu com o cooperativismo da Fucvam renascerão em outro lugar". 
"Hoy nos declarmos públicamente en guerra y movilización permanente contra los latifundistas urbanos, los especuladores inmobiliarios, los capitalistas de la construcción, los banqueros, y la burocracia enquistada en las estructuras institucionales de la Revolución que los apoyan. Somos el mismo pueblo de Zamora, que hace 160 años se declaró en insurrección popular para dar la batalla contra la oligarquia dueña de la tierra rural, los mismos excluidos de siempre, ahora en la ciudad, unificados en torno al liderazgo de nuestro Comandante Hugo Chávez y el Proyecto Socialista".

Movimiento de Pobladoras y Pobladores Manifiesto por la Revolución Urbana

A partir dos Comités de Tierras se formou na Venezuela um amplo movimento social urbano, reunido em torno da plataforma do Movimiento de Pobladoras y Pobladores. Fazem parte do movimento os próprios CTU’s, os Campamentos de Pioneros, Ocupantes de Edifícios, Trabalhadores de Edifícios e Inquilinos.

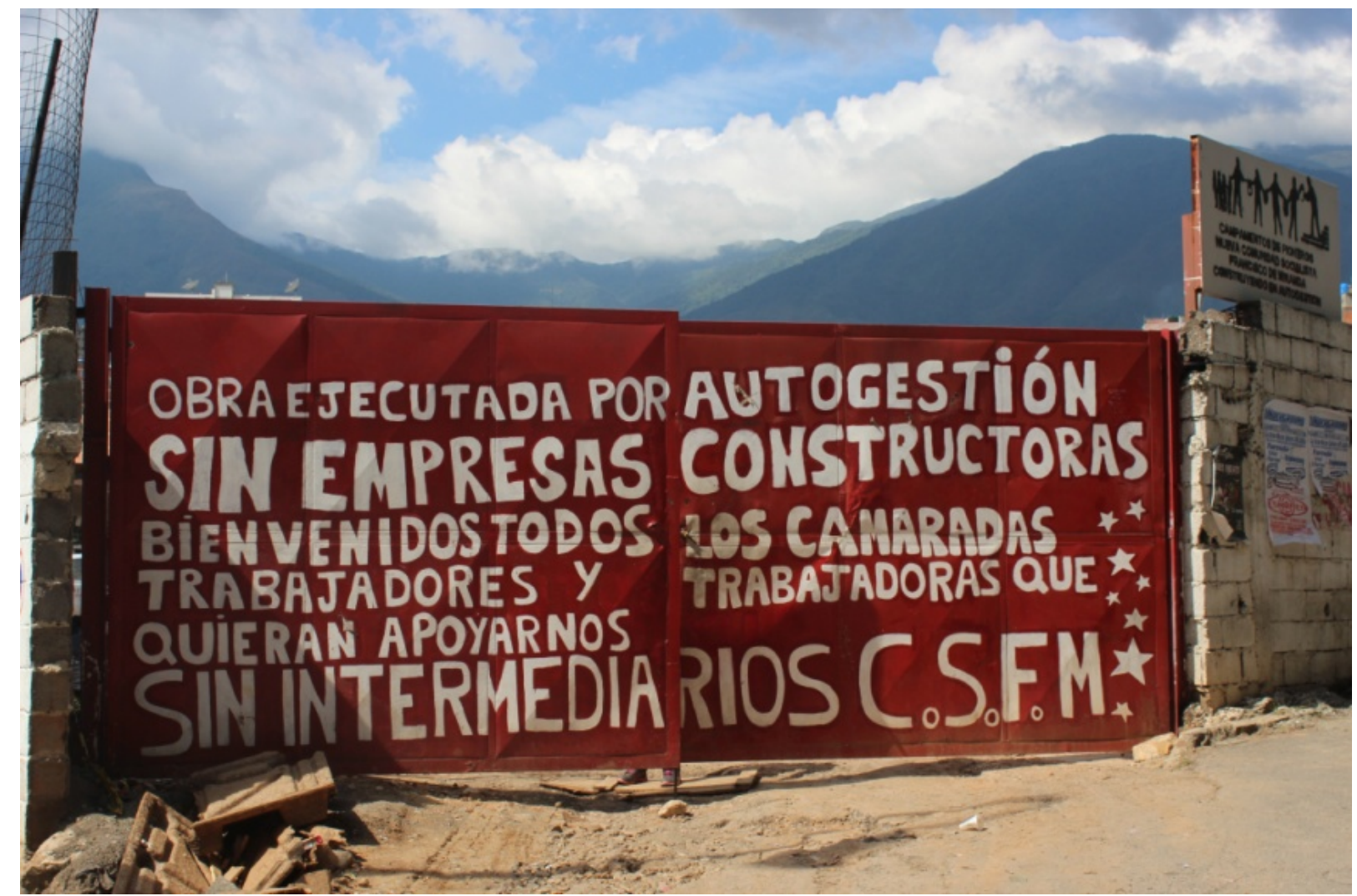

Fig 65: Portão de entrada da Nueva Comunidad Socialista Francisco de Miranda. Foto do autor. 
Em seu manifesto, o Movimiento de Pobladoras y Pobladores introduzem da seguinte forma sua perspectiva sobre o problema da habitação na Venezuela:

"Históricamente, el capitalismo rentista y especulativo, financiado con el enorme ingreso que implicó la renta petrolera, el negocio inmobiliario y de la construcción, ha hecho de la ciudad un espacio permanente de reproducción de capital y transferencia de la riqueza a los sectores concentrados de la economía, mercantilizando el espacio urbano y negando a los sectores populares y a la clase trabajadora, la posibilidad de acceder a un lugar donde vivir con dignidad".

A partir dessa perspectiva, o movimento busca articular as lutas contra "las distintas expresiones del capitalismo en la ciudad", por meio da "transformación socialista de las relaciones capitalistas de producción de la ciudad".

Segundo o Manifiesto por la Revolución Urbana, são objetivos do movimento:

- Defesa pelo direito à habitação,

- A luta pela democratização da cidade e pela Revolução Urbana,

- A reivindicação do povo como produtor do hábitat,

- A luta pela democratização do acesso ao solo urbano y pela garantia de sua função social,

- O "enfrentamento decidido" à especulação imobiliária,

- A construção do socialismo e do poder popular.

Um marco importante da influência das experiências latino-americanas para os movimentos de moradia da Venezuela foi o Fórum Social Mundial de 2006, sediado em Caracas. Nesta ocasião foi possível estreitar os laços com as organizações irmãs da América Latina. A partir de então o Movimiento de Pobladoras y Pobladores se tornou membro da Secretaria Latinoamericana de la Vivienda Popular SELVIP, que articula organizações populares de base latinoamericanas, como a Federación Uruguaya de Cooperativas de Vivienda por Ayuda Mutua - FUCVAM (Uruguai), o Movimiento de Ocupantes e Inquilinos - MOI (Argentina), a Federación de Tierra e Vivienda - FTV (Argentina), a União Nacional por Moradia Popular - UNMP (Brasil), e o Movimiento de Pobladores en Lucha (Chile).

Segundo Mariela Machado, do Campamento de Pioneros Kaika-Shi,

"Los CTUs han tenido mucha relación con gente de otros colectivos, la brigada Ali Primera, en Cataluña, con los sin tierra en Brasil, eran encuentros que se hacían aqui, y se invitaban, y ellos venían, que es la Selvip, que hace vivienda popular latinoamericana. $Y$ nosotros definimos, bueno, hacer una experiencia con ellos. Los CTUs con la Transformación Integral de Barrio le tocó ir una vez a Brasil y de ahí se hace la relación con la gente de la Selvip y le asume Pioneros como tal. Entonces hemos ido haciendo intercambio con ellos, ellos vienen y nosotros vamos. No podemos decir 
que somos directamente la Selvip, pero estamos ahí, del Plan latinoamerica de vivienda popular".

O XIII Encuentro de la Secretaría Latinoamericana de Vivienda Popular (Selvip) foi realizado em Caracas em julho de 2011. O tema do encontro era "Construyendo la Vía Urbana en América Latina: por el fortalecimiento de la autogestión popular en procesos de transformación social" ${ }^{47}$. O evento de encerramento, no Teatro Teresa Careño, contaria com a presença de Hugo Chávez. A ida à Cuba para tratamento do câncer impediu sua presença, sendo representado então pelo vice-presidente Elias Jaua. Durante o evento foi realizada marcha por Caracas, com a presença de significativa quantidade de pessoas $^{48}$.

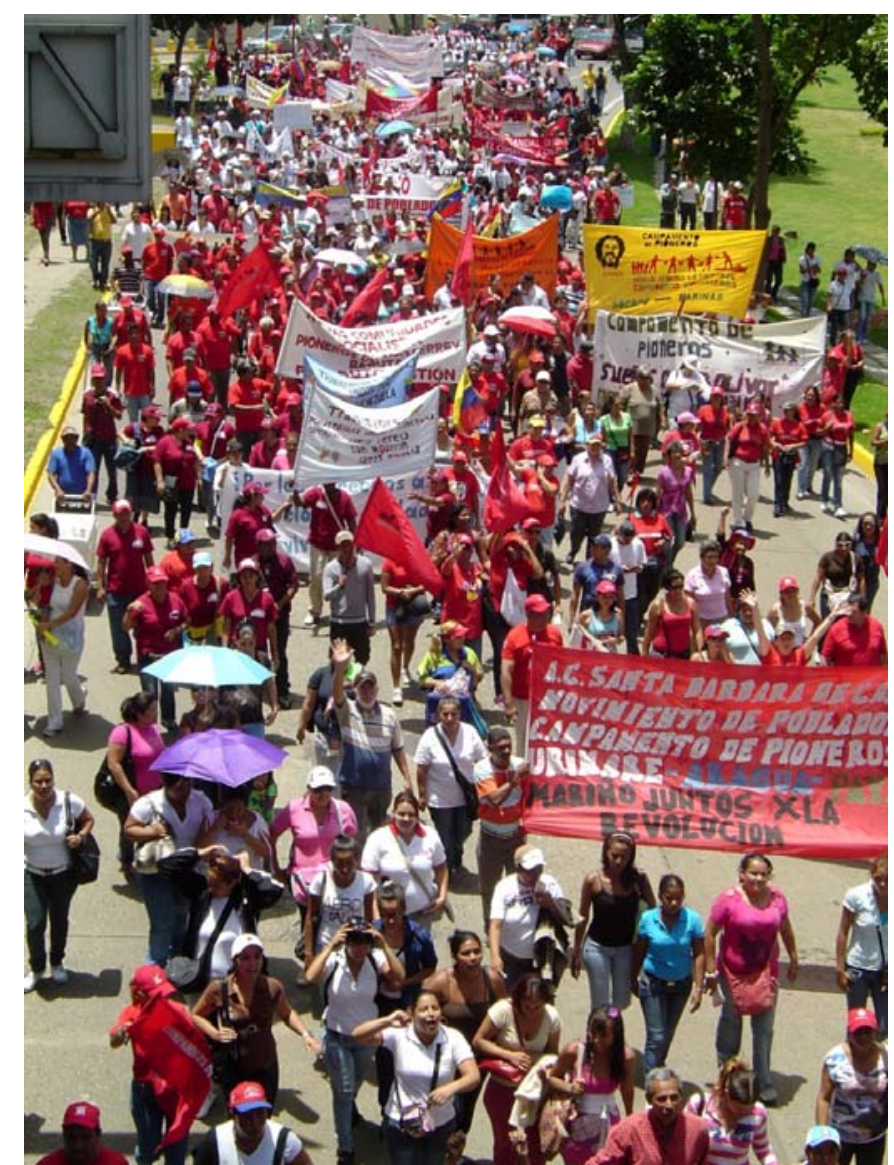

Fig. 66: Marcha da Selvip por Caracas em 2011.

Foto do autor.

\footnotetext{
47 Segundo a Declaração Final do Encontro: "La Vía Urbana es un camino que no antagoniza con la lucha campesina, está inscrita en la totalidad de la lucha de clases y en la totalidad del territorio. El desarrollo urbano capitalista no se limita al espacio de la ciudad: es una lógica dominante de apropiación del territorio y la riqueza producida colectivamente, donde la explotación y la expropiación de nuestros recursos naturales van también a reproducir el circuito del capital en las ciudades. Al respecto declaramos que asumimos el compromiso de Impulsar una Vía Urbana, como expresión de articulación de los oprimidos y oprimidas de la ciudad". Durante o Encontro, o debate mais acalorado ocorreu em torno da proposta de inserir, como lema da Selvip, a busca pelo socialismo. Os movimentos da Venezuela defendiam arduamente o socialismo como bandeira, ponderado por outros movimentos, sobretudo do Brasil e Argentina. Na Declaração Final não há menção ao socialismo.

${ }_{48}$ Durante os anos em que vivi em Caracas, pude perceber que é incomum grandes manifestações de movimentos setoriais - como ocorre no Brasil com sem-terra, sem-teto e recentemente passe livre. Por outro lado, as manifestações em defesa ou contra o chavismo sempre assumiam proporções gigantescas.
} 
No Manifiesto de 2010, os Pobladores elencaram as seguintes propostas e reivindicações:

- Plano Nacional para regularização da posse da terra urbana,

- Programa de Transforção Integral de Barrios,

- Incentivo ao programa das Nuevas Comunidades Socialistas,

- Implementação de medidas que permitam garantir a "Función Social de Suelo Urbano", sua socialização e acesso aos setores populares,

- Desenvolvimento de um sistema público e popular de produção de vivienda y habitat,

- Criação de um programa de créditos coletivos autogestionários para a construção de novos empreendimentos habitacinais, aquisição e remodelação de edifícios,

- Regularização da situação de famílias ocupantes de imóveis abandonados,

- Identificação e recuperação de imóveis ociosos para o desenvolvimento de projetos para famílias em moradia,

- Incentivo ao processo de organização, mobilização e participação de familias afetadas pelas chuvas,

- Fim dos despejos arbitrários de famílias inquilinas, ocupantes, e trabalhadores de edifícios (conserjes).

- Incentivo a uma política de acompanhamento integral aos trabalhadores y trabalhadoras de conserjerías.

- Criação de um banco de projetos populares de vivienda y habitat,

O Movimiento de Pobladoras y Pobladores funciona como um "guarda-chuva" de movimentos autônomos, que reúnem suas lutas a depender da situação. Juan Carlos Rodriguez, liderança dos Campamento de Pioneros, carateriza o movimento como uma plataforma:

"Los Pobladores es una plataforma de organizaciones de luchas urbanas. Y ahí, dentro de esa plataforma están los Comités de Tierras, que son organizaciones barriales, están los pioneros, están las organizaciones de los ocupantes, están las organizaciones de los inquilinos, los trabajadores residenciales, y así seguimos nos formando sujetos de lucha urbana. Una plataforma de lucha urbana". 


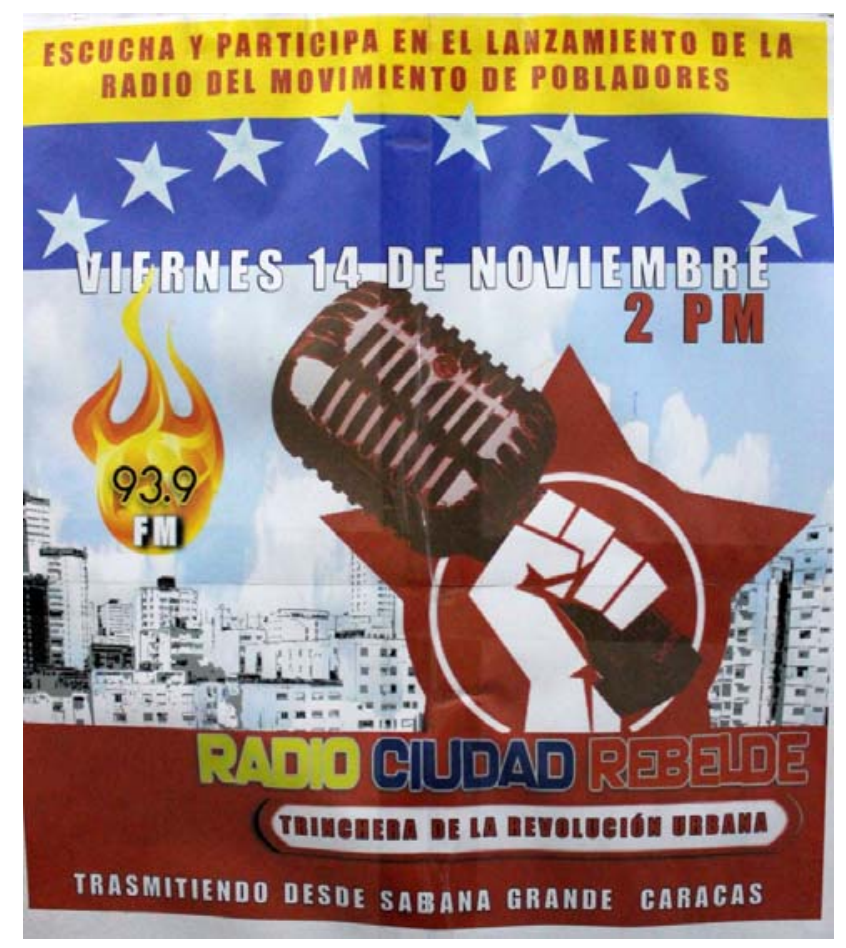

Fig. 67: Cartaz da rádio Ciudad Rebelde. Foto do autor.

No dia 14 de novembro de 2014 o Movimiento de Pobladoras y Pobladores inauguraram uma rádio livre, a Radio Ciudad Rebelde: Trinchera de la Revolución Urbana. A sede da rádio e a antena de transmissão se localiza no Edifício Continental, prédio ocupado pelo Movimiento de Ocupantes de Edifícios Organizados de Venezuela (MOEOV).

Segundo Harrison Moya, liderança do MOEOV, com a eleição de Hugo Chávez em 1999 muitos empresários saíram do país e deixaram centenas de imóveis desocupados. Segundo Harrison, "muchos empresarios se fueron. Mas anterior a eso, habían muchos espacios ociosos, en engorde, buscando ganar alguns benefício, espacios que tenían 15, 20 años totalmente desocupados, edifícios con apartamentos e todo. [...] De ahí que las personas empezaron hacer una investigación y empezaron a ocupar los inmuebles. Que no fueron de la manera organizativa, que fueron de una manera sin orientación, y ocuparon uns 300 y picos inmuebles en la ciudad, y después fueron ocupando en otros estados, como Barquisimeto, Lara, San Cristóbao, Miranda...".

Outro momento importante foi o ano de 2006, quando as chuvas deixaram centenas de desabrigados, e o prefeito de Caracas (Alcadía Mayor), Juan Barreto aceitou as reinvidicações das famílias e desapropriou 37 imóveis vazios. Segundo Harrison, o movimento conta com cerca de 120 edifícios ocupados que abrigam cerca de 5.200 famílias.

Assim como outros movimentos, o MOEOV nasceu também do trabalho de base das favelas: 
"Nosotros antes de sermos ocupantes, eramos CTU, eramos comités de salud, barrio adentro. Nosotros venimos de ahí pues. De todas esas raízes con el tema de la organización. Nosotros nos juntamos aqui, empezamos como en 2009, 2010, que empezamos a ver que era necesario que nos juntemos, para ir impulsando como una política. Una política en conjunto para que todos se beneficien, y ahí en 2010 nosotros hicimos una gran mobilización a la vice presidencia donde los llevamos un manifiesto sobre la Revolución Urbana y el comandante Chávez, el 8 de enero de 2011 nos hizo un llamado en El Calvario. Conversatório con el Movimiento de Pobladores y con varias organizaciones".
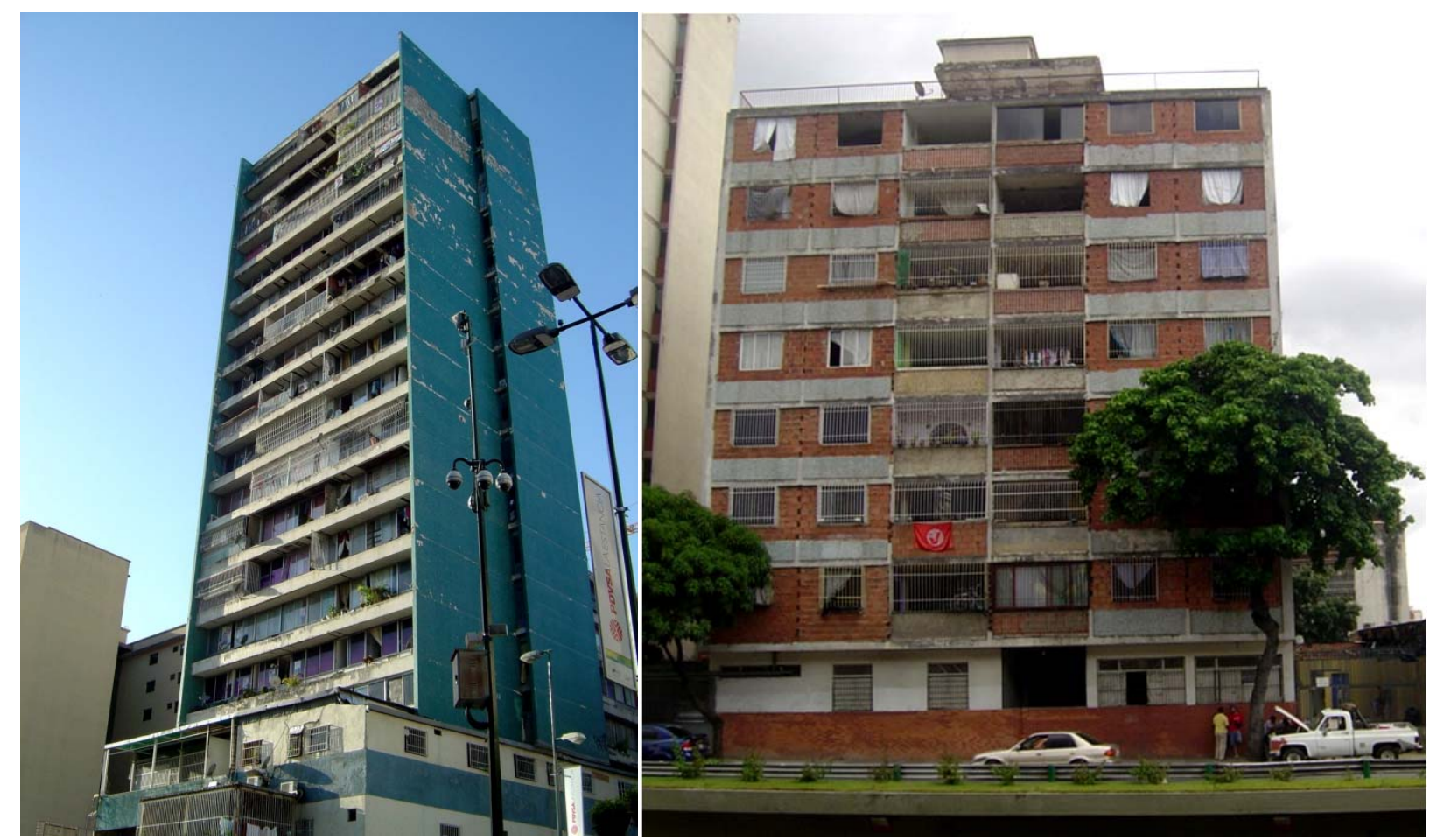

Fig. 68 e 69: Edifício Continental no Boulevard Sabana Grande; Edifício Flórida na Avenida Libertador. Fotos do autor.

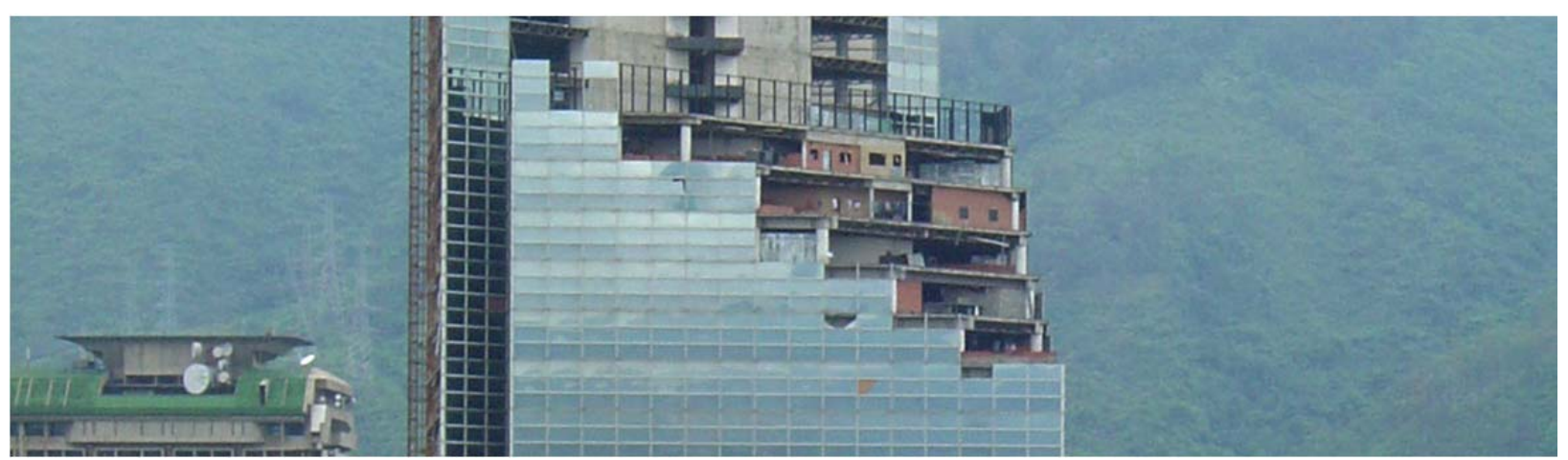

Fig. 70: A auto-construção no arranha-céu de Caracas. Foto do autor. 


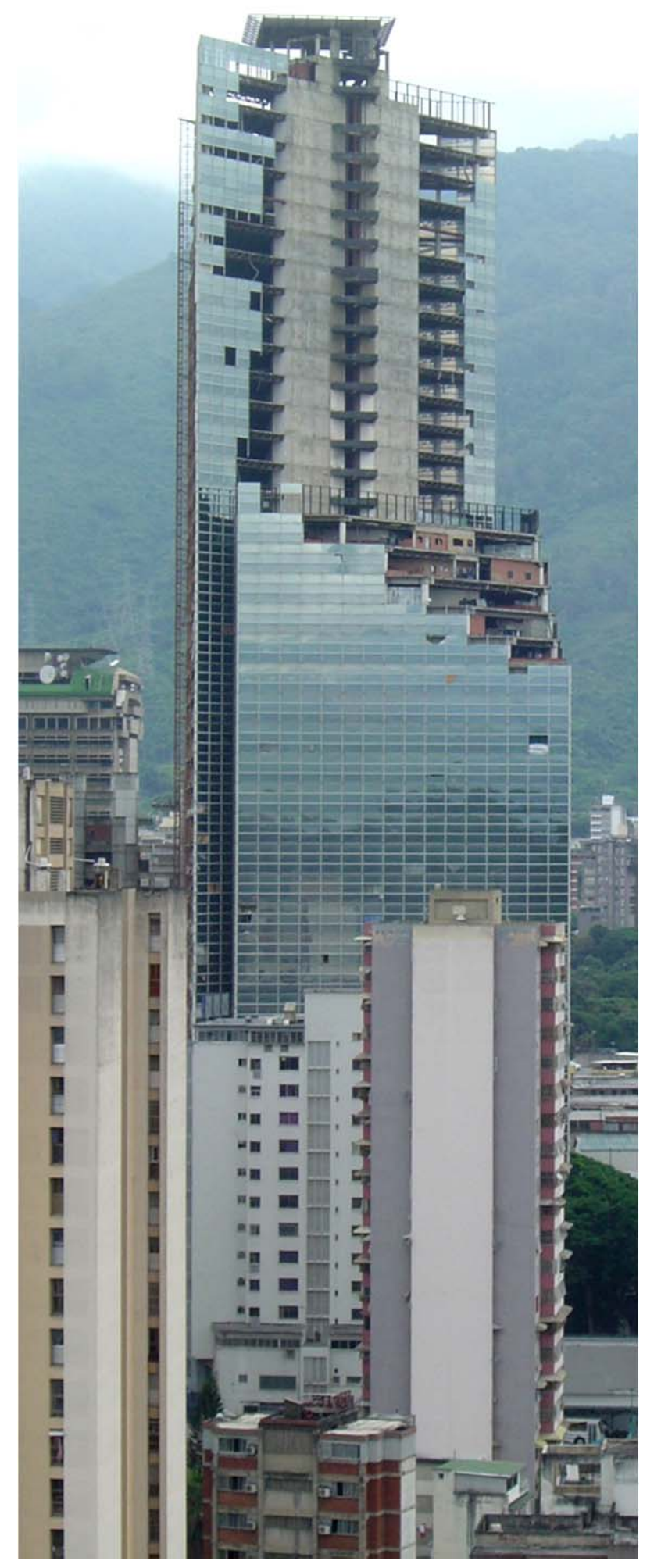

Fig. 71: Torre David. Foto do autor.
O caso mais conhecido de edifício ocupado da Venezuela é a torre do Centro Financeiro Confinanzas, conhecida como Torre David. Trata-se de um arranha-céu de 190 metros de altura e 45 pisos, ocupados por famílias no ano de $2007^{49}$.

O Movimiento de Pobladoras y Pobladores abarca ainda a Red Metropolitana de Inquilinos e uma oraganização de trabalhadores de edifícios (como porteiros e zeladores). Durante nossa pesquisa de campo não realizamos contato com esses movimentos.

Os Campamentos de Pioneros - Nuevas Comunidades Socialistas foi o principal foco de nossa pesquisa em relação ao movimento social.

49 David Brillembourg, principal acionista do grupo Confinanzas, enriqueceu durante o boom da bolsa de valores de 1990. A partir de então, investiu parte de sua riqueza em um grande negócio imobiliário, que teria como objetivo transformar aquela região central de Caracas em um distrito financeiro.

Com a quebra do grupo, a construção iniciada em 1990 foi paralisada em 1994, passando a ser propriedade do Estado. No ano de 2014 foi realizada a desocupação em acordo com as famílias. 


\subsection{Os Campamento de Pioneros - Nuevas Comunidades Socialistas}

"Los Comités de Tierras Urbanas son una organización del barrio, para la regularización. Digamos que formalmente desde el año 2002, cuando surge el decreto de regularización, pero como organización barrial, digamos que los Comités de Tierras viene de las luchas de barrios de los años 80, como organización, como militancia. Los própios trabajadores sociales del barrio que impulsamos la idea del Campamento de Pioneros, desde esa época venimos trabajando en eso".

Juan Carlos Rodriguez - Campamento de Pioneros

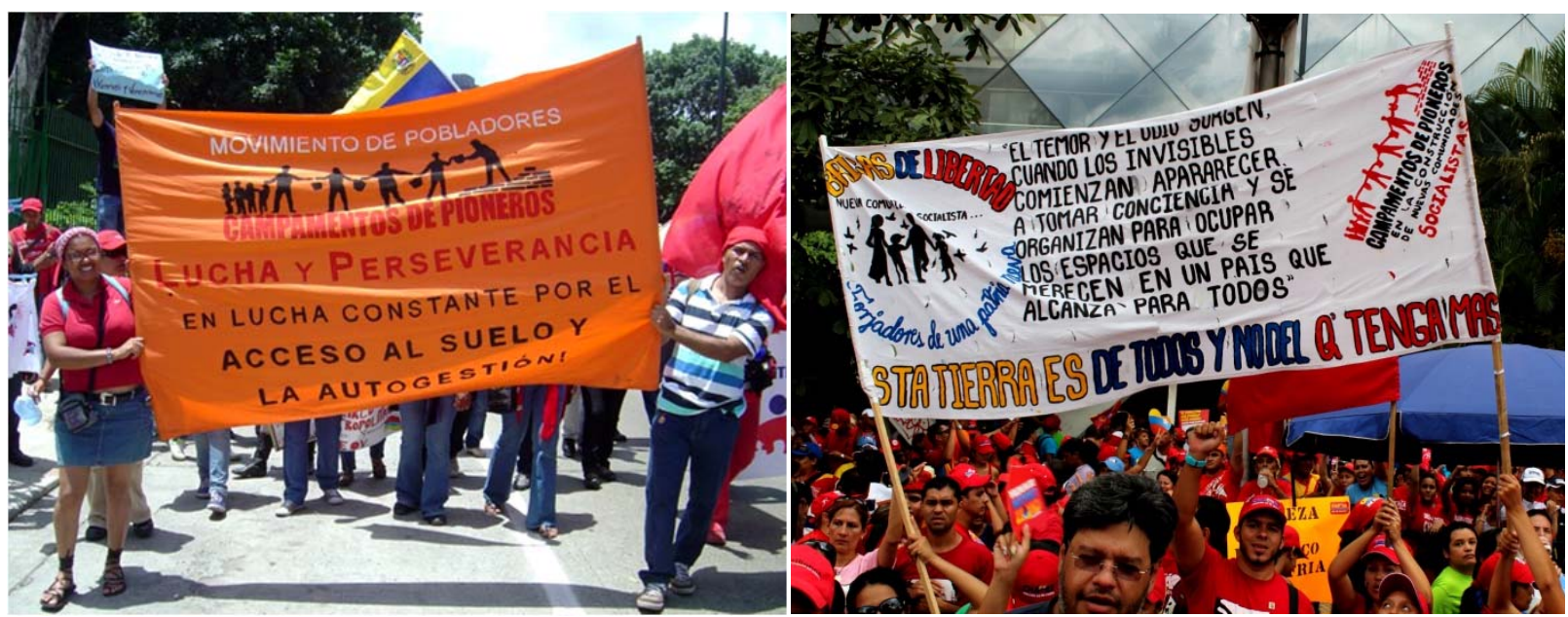

Fig. 72: Marcha do XIII Encuentro de la Selvip; Fig. 73: Marcha durante eleições presidenciais em 2012 Fotos do autor.

Segundo a definição contida no Manifiesto,

"Los Campamentos de Pioneros y Nuevas Comunidades Socialistas articulamos experiencias de organización de familias 'sin vivienda'(damnificadas, en riesgo, alquiladas, arrimadas, hacinadas o en otra forma de alojamiento dependiente), en la lucha por el acceso al suelo urbano, para la producción de nuevas comunidades y la construcción de un proyecto de vida coletiva, bajo un modelo autogestionario de planificación participativa de proyectos integrales de hábitat y vivienda, de propiedad colectiva y tabajo solidario". 
Os princípios que regem os Campamentos de Pioneros o acercam de outros movimentos latinoamericanos, como a Fucvam, a União dos Movimentos de Moradia (Brasil) e o Movimimento de Ocupantes e Inquilinos ${ }^{50}$ (Argentina).

Kaya Lazarini, caracteriza da seguinte forma a produção habitacional por autogestão pelo Movimiento de Ocupantes e Inquilinos da Argentina,

"Quantitativamente, essas experiências são sempre reduzidas. Onde são implementadas, respondem, quase sempre, por apenas uma pequena parte da produção habitacional. Qualitativamente, a produção é regida por parâmetros construtivos e projetuais distintos dos habitualmente utilizados para a produção habitacional para a baixa renda, ou seja, a qualidade dos conjuntos concebidos e produzidos por seus próprios usuários é certamente superior aos conjuntos que não são pensados por esses sujeitos. Este projeto (político e arquitetônico) pressupõe participação efetiva e questiona, constantemente, a lógica de produção habitacional tradicional. O valor de uso sobressai em relação ao valor de troca".

Além da expressão Campamentos de Pioneros, também é comum a utilização da expressão Nuevas Comunidades Socialistas. Em entrevista abordamos o significado dessa expressão a Juan Carlos Rodriguez, que enfatizou as relações de produção.

"- Cuando se dice Nuevas Comunidades Socialistas, cual es la diferencia entre una Nueva Comunidad Socialista y un conjunto habitacional...

- Bueno, nuevas relaciones de producción. Nuevas relaciones de producción no capitalistas. Aqui no hay empresa. Aquí quien produce es la organización. Por eso se trata de planificación de la producción, de la organización de la fuerza de trabajo a través de una organización de la própia, del própio sujeto, pues. Es una nueva relación de producción, de la ciudad, de la vivienda".

Atualmente cerca de 3.000 famílias fazem parte dos Pioneros, organizadas em 35 campamentos. Os Pioneros mantém uma sistemática de 4 reuniões semanais, com temas específicos:

- Segunda-feira: Reuniões políticas para definição de táticas e estratégias (todos campamentos, cerca de 40 pessoas),

- Terça-feira: Reuniões para formação de novos grupos (80 pessoas)

- Quarta-feira: Articulação para a autogestão dos empreendimentos (campamentos em obras, cerca de 20 pessoas),

\footnotetext{
50 "Autogestão, ajuda mútua e propriedade coletiva. Os três eixos que fundamentam o Movimento de Ocupantes e Inquilinos têm suas raízes na experiência uruguaia, e são determinantes para compreender a organização" (Lazarini, 2014).
} 
- Quinta-feira: Articulação para consolidação de campamentos em luta (15 pessoas),

Aos sábados, a cada 15 dias, são realizadas reuniões ampliadas, com a participação de cerca de 110 representantes, para a formação "integral e coletiva" do movimento.

Os novos grupos que se reúnem nas terças-feiras conformam uma organização semelhante às guardias de autogestión argentinas. Sobre isso, Kaya Lazarini explica que "as famílias que originam a cooperativa são provenientes das guardias de autogestión, ou seja, espaços de formação do movimento para que cada família ingressante entre em contato com os conceitos de cooperativismo, autogestão, propriedade coletiva, etc". Guardadas as diferenças de contexto, também podemos relacioná-los aos grupos de base da cidade de São Paulo.

A maioria da assessoria técnica se dá pela contratação de arquitetos e escritórios desvinculados do movimento, com maior ou menor alinhamento político. Em conversa com militantes dos Pioneros, o não alinhamento político ou a inabilidade do profissional diante do trabalho participativo com as famílias levou a situações de tensionamento e afastamento de profissionais. O movimento conta com a participação de dois arquitetos orgânicos, Juan Carlos Rodriguez e David Grajales, cujas atuações extrapolam o ofício da arquitetura, assumindo o papel de lideranças políticas.

Os eventos de intercâmbio continental, como o XIII Encontro da Selvip e o 4o. Encuentro Latinoameticano de Arquitectura Comunitaria (ELAC) possibilitaram a troca de experiências em relação à arquitetura, projeto participativo e autogestão da obra. Nessas ocasiões, e durante todo o ano de 2013, tivemos a oportunidade de apresentar metodologias de projeto participativo, exemplos de obras ao movimento, assim como apresentar e debater o documentário Capacetes Coloridos ${ }^{51}$.

\footnotetext{
${ }^{51}$ Documentário realizado por Paula Constante, que realiza comparação entre um canteiro de obras tradicional (no caso, a construção da USP Leste) e um canteiro de mutirão autogerido (mutirão Paulo Freire na zona leste de São Paulo). Mais informações em www.capacetescoloridos.net, sítio onde o documentário está disponibilizado.
} 


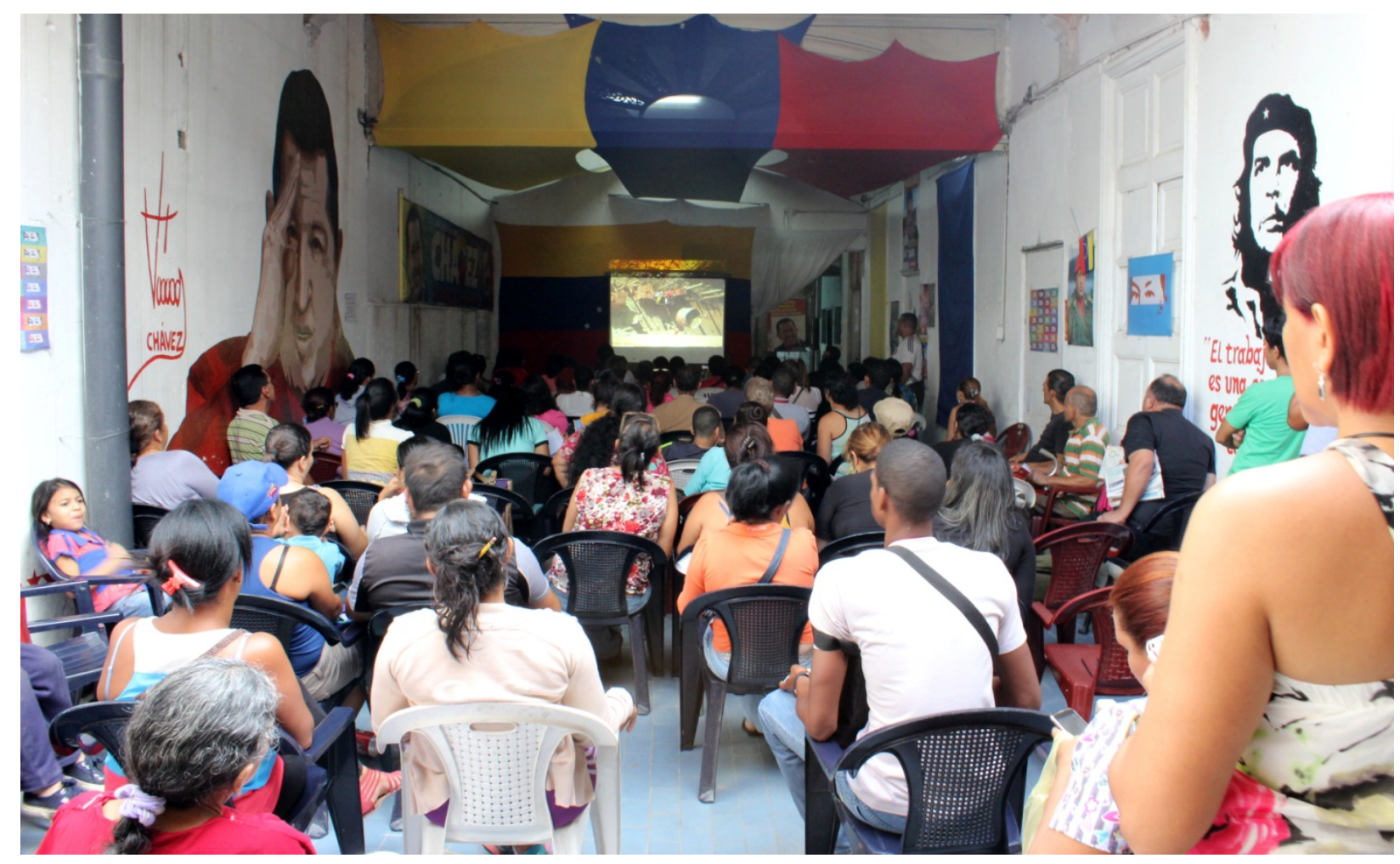

Fig. 74: Projeção do documentário Capacetes Coloridos na reunião de terça-feira (formação de novos grupos), na Cuña de Libertadores. Foto do autor.

As reuniões maiores, como as de terça-feira para a formação de novos grupos são realizadas em uma casa no centro da cidade, distante 2 quadras da principal praça de Caracas, a Plaza Bolívar. A casa, nomeada de Cuña de Libertadores, é uma importante base do movimento urbano, onde se realizam reuniões do Movimiento de Edíficios Ocupados (que mantém sala própria dentro da casa) e dos Comités de Tierras Urbanas, entre outros coletivos e movimentos.

\section{Propriedade coletiva e Crédito coletivo.}

Na primeira vez que estivémos na Venezuela, em março de 2011, pudemos participar de uma das reuniões de terça-feira, ou seja, para a formação de novos grupos de Campamentos de Pioneros. Naquela ocasião, era forte o debate sobre a necesside dos Pioneros utilizarem o crédito coletivo, assim como assumirem a propriedade coletiva.

O crédito coletivo é condição primeira para a construção de edifícios por autogestão, ao permitir o financiamento do Estado a um grupo, dotado de um figura jurídica própria, que fará a gestão de forma coletiva. No Brasil, o mutirão habitacional durante a gestão de Luiza Erundina (1989-1993) em São Paulo contou com o programa Funaps Comunitário (Ronconi, 1994), que possibilitou de forma sistemática e ampla o acesso ao crédito coletivo. Em âmbito federal será apenas em 2004 com a criação do programa Crédito Solidário que será possível o financiamento federal às associações. Atualmente, o 
programa de crédito coletivo em nível federal se dá por meio da modalidade Entidades do programa Minha Casa Minha Vida.

Na Venezuela até 2011 não havia o financiamento coletivo às associções. É curioso notar que o contexto político levou a uma interessante situação na qual a reinvindicação por crédito coletivo nasceu junto com a bandeira da propriedade coletiva. O crédito coletivo e a propriedade coletiva de fato podem fazer parte de um mesmo processo, sendo o primeiro responsável pela propriedade coletiva dos recursos financeiros que se transformarão em área construída, enquanto a segunda consolida a propriedade coletiva do resultado coletivamente construído, desta vez incluída a propriedade da terra. Tal encadeamento crédito coletivo-propriedade coletiva se coloca como alternativa ao procedimento padrão, no qual o produto coletivamente construído, após concluída a obra, é fracionado em propriedades individuais (via fração ideal).

Nessa perspectiva, é interessante notar a fala, naquela reunião de março de 2011, da liderança dos Campamentos de Pioneros, Iraída Morocoima. Percebe-se que, na defesa do crédito coletivo está também subentendida a defesa da propriedade coletiva:

"Las condiciones cambiaron. Y ya tenemos el camino, pero esa lucha quedaría en vano si nosotros individualizamos la vivienda. Si nosotros no las respaldamos, y después que tanto nos jodimos por lucha por esa tierra, que tenemos que criar el crédito colectivo, coletivizar la comunidad, porque lo crédito colectivo es una escusa para construir socialismo compañeros, porque es la unica forma de nosotros soñar que la gente se conoce, que va a vivir en una comunidad, con sus diferencias, pero va a vivir en una comunidad donde todos puedan decidir. No, porque tampoco es vida vivir en un edifício donde la gente no se conoce. Y como queremos vivir viviendo, vamos a ir transformando. La lucha por la tierra no tiene sentido sin el crédito colectivo. Eso tiene que ser el princípio fundamental. $Y$ entonces la gente después se pregunta, y nosotros temos discutido en el barrio: mi vivienda va ser la tuya? si, compañero, es posible que todos tengamos la privacidad que la familia necesita, pero la vivienda va ser la tuya, y la mia también. Porque es eso, si no, se va seguir viendo la casa como un carro, y que no la vemos como un carro!"

Na mesma ocasião, outra liderança dos Pineros, Juan Carlos Rodríguez, colocava a bandeira da propriedade coletiva de forma explícita:

"Acá se plantea una nueva forma de propiedad, que es la propiedad colectiva. La propriedad es de la organización. No es propiedad individual de la vivienda, es propriedad colectiva de la comunidad. Y cada familia miembro de la organización lo 
que tiene es derecho de uso exclusivo de esa vivienda. Nadie puede, digamos, estar dentro del conjunto de la comunidad si no forma parte de la organización. Porque no es porque yo soy dueño de mi vivienda, sino que yo soy dueño, o nosotros somos dueños y dueñas de nuestra comunidad. Es una nueva forma de propiedad. Porque planteamos la propiedad coletiva? Bueno, porque vamos a ponernos en ejercício: el Estado nos da el suelo, la plata para la asistencia técnica, urbanizamos, construimos, etc., y esa vivienda termina costando 180 mil bolos, por poner un caso. Lo que resulta es que, otro dia estábamos en Campo Rico [Nueva Comunidad Socialista Francisco de Miranda], y los apartamentos que están en frente valen 800 mil bolos. Bueno, cualquier familia de esa se va a ver tentada, si la propiedad for individual, una vez que termine, yo la vendo".

No Brasil, enquanto a forte reivindicação pelo crédito coletivo levou a conquista históricas, a bandeira da propriedade coletiva tem apresentado pouco poder de mobilização popular.

Situação diferente do Uruguai, onde a propriedade coletiva é um dos elementos fundamentais na formação da Fucvam. Tão importante é a propriedade coletiva para a Fucvam que, segundo Baravelli (2006), a defesa dessa bandeira resultou em uma das mais importantes mobilizações durante o regime militar:

"A resposta do regime militar foi um projeto de lei que obrigava as cooperativas de ajuda mútua a aderir ao regime de propriedade individual das moradias, individualizando o financiamento habitacional. Sabendo que o projeto de lei não encontraria oposição num legislativo controlado, a direção da Fucvam aproveita-se de um instrumento de democracia direta preservado na constituição uruguaia e pede a "plebiscitación" da lei. Se o pedido fosse subscrito por pelo menos 500 mil eleitores, obrigava que uma lei aprovada no legislativo só entrasse em vigor depois de uma consulta popular. Em poucos dias de fevereiro de 1984 foram recolhidas 600 mil assinaturas de apoio ao regime de propriedade coletiva nas cooperativas, no que se tornou uma campanha nacional com adesões de diversas organizações sociais e forças políticas proscritas" (Baravelli, 2006: 70).

Segundo Kaya Lazarini, a propriedade coletiva constitui uma diferença fundamental entre a Lei de Habitação uruguaia e a Lei argentina. O artigo 144 da lei habitacional uruguaia indica que "las unidades cooperativas de usuários sólo atribuyen a los sócios cooperados derecho de uso y goce sobre las viviendas.” Na Argentina o Movimiento de Ocupantes e Inquilinos elenca entre seus princípios a propriedade coletiva; no entanto, como o movimento não tem obras concluídas não é possível saber como será efetivada essa forma de propriedade (Lazarini, 2014: 59).

$\mathrm{Na}$ Venezuela, em termos jurídicos, tampouco existe a figura da propriedade coletiva, conforme entrevista que realizamos em novembro de 2012 com Juan Carlos Rodríguez: 
"- Como está el tema de la propiedad colectiva?

Para nosostros Pioneros la única forma de propiedad que impulsamos es la propiedad colectiva. Hay otras formas de propiedad en Venezuela, propiedad multifamiliar, pero para nosostros un punto central y uno de nuestros princípios es la propiedad colectiva. Tanto de la tierra como de la vivienda.

- Me acuerdo que, la primera vez que estuve aqui la discusión dentro de los probladores...

En Pobladores ni todos tienen la misma visión sobre la propiedad que los Campamentos de Pioneros. En caso de Comités de Tierras la propiedad colectiva todavia no es digamos un tema central, se habla de propiedad familiar, la propiedad comunal. Porque es distinta la relación de la propiedad en los barrios con la que nosotros planteamos en la hora de construir algo nuevo. Para nosotros Pioneros si, es la propiedad colectiva.

- Existe la figura jurídica de la propiedad colectiva?

Bueno, no existe la propiedad colectiva constitucionalmente, legalmente, hay varios proyectos para instaurar la forma de propiedad colectiva. Bueno, lo que hacemos es lo que se hace en todo el mundo, o que se hacen en otras partes del mundo, constituimos una figura jurídica que es propietaria. Juridicamente la propiedad colectiva esta como que enunciada en la constitución. Pero no está desarrollada legalmente. Hay varios proyectos sobre la propiedad social, la propiedad social directa, la propiedad social indirecta, la propiedad colectiva, la propiedad comunal... pero todavía es un proyecto, no está establecido como forma de propiedad. Distinta es la propriedad privada individual, que es el marco jurídico vigente".

\section{O Projeto}

Os Campamentos de Pioneros contam com uma sala técnica, onde realizam as reuniões menores e elaboram os projetos. A sala técnica é bancada por um fundo comum formado por alguns Campamentos com obra em andamento, que pagam o aluguel da sala, a compra dos equipamentos e o pagamento de técnicos que se dedicam a obras específicas mas também a questões que envolvem o movimento como um todo. 


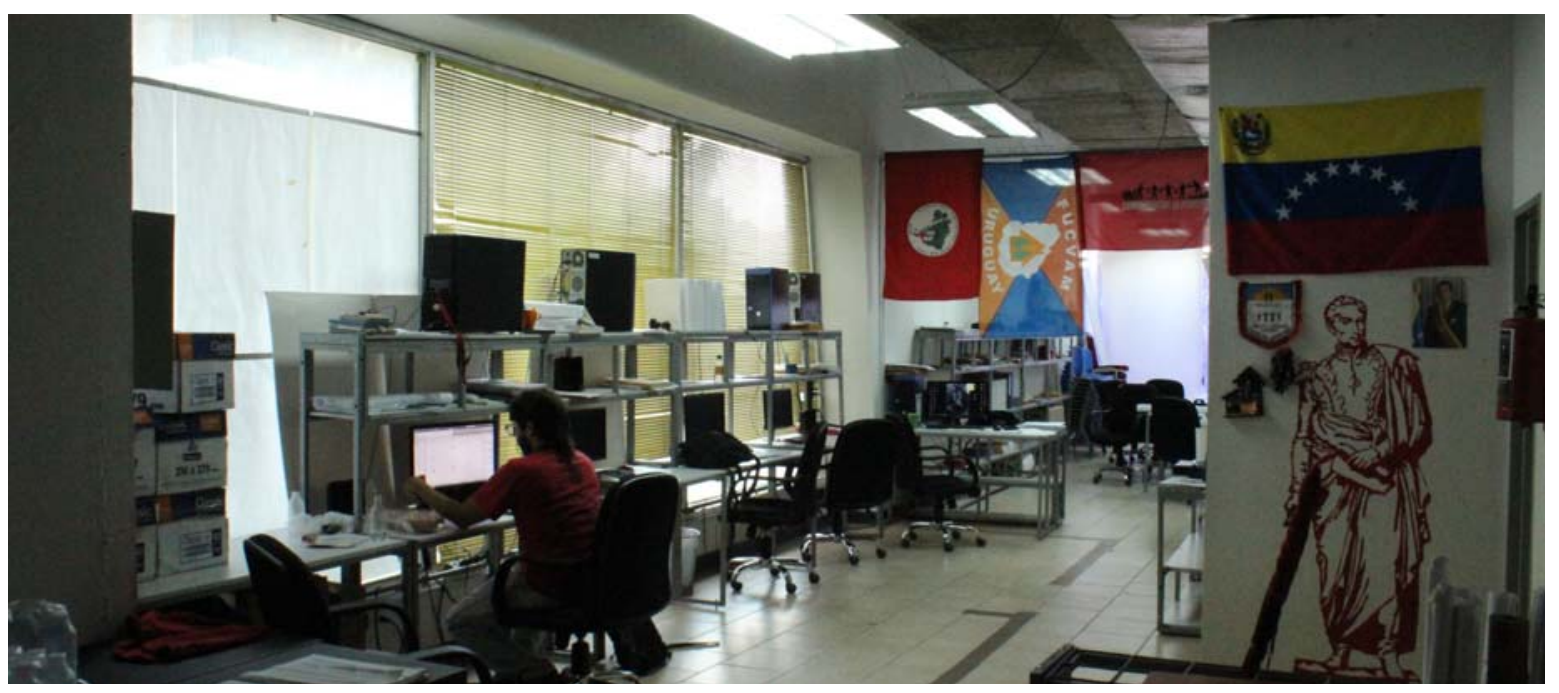

Fig. 75: Sala Técnica, com bandeiras da FUCVAM e MST. Foto do autor.

Os projetos dos Campamentos de Pioneros se destacam pela qualidade projetual e pela organização coletiva das famílias, que propõe o diseño participactivo durante o projeto e a autogestão no processo construtivo.

A partir das primeiras experiências de projeto participativo, os Campamentos de Pioneros começaram um processo de sistematização de uma metodologia de projeto participativo. O processo de projeto é basicamente realizado em 4 fases: caracaterização, autodiagnóstico, plano comunal e planejamento participativo. Em cada fase se trabalham três níveis da sociedade: familiar, comunal e urbana.

Denominar a fase 2 como autodiagnóstico marca a posição do movimento em se diferenciar do diagnóstico tradicional, feito a partir de técnicos de fora do coletivo. O autodiagnóstico se transforma, assim, em reconhecimento.

Os Campamentos de Pioneros mantém a prática dos Comités de Tierras Urbanas de elaborar a Carta del Barrio, onde além da caracterizarem os aspectos básicos da comunidade (localização, população, etc.), contam a história do terreno (a forma de ocupação, quanto tempo esteve subutilizado, etc.), da luta daquele coletivo, das articulações políticas. 


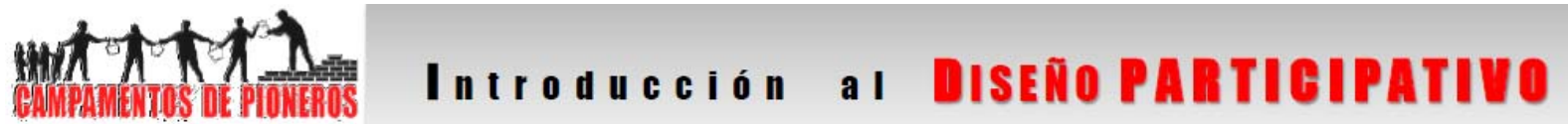 Planificación y Diseño participativo}

1. Taller de Caracterización
A. Familiar. Conocer la realidad de nuestras familias.
B. Comunal. Conocer la realidad de nuestra comunidad en colectivo.
C. Urbana. Conocer la realidad de nuestro entorno urbano.

2. Taller de Auto diagnostico
A. Familiar. Debatir la realidad de nuestras familias para definir la necesidad de cada grupo familiar.
B. Comunal. Debatir la realidad de nuestra comunidad para definir nuestras necesidades colectivas y nuestras potencialidades.
C. Urbana. Debatir la realidad de nuestro entorno para definir necesidades y potencialidades espaciales y urbanas de integración.

3. Taller de Formulación plan comunal

A. Familiar. Proponemos y transformamos nuestra realidad familiar (la vivienda).

B. Comunal. Proponemos y transformamos nuestra realidad comunal y (Equipamientos y espacios colectivos).

C. Urbana. Proponemos y transformamos la realidad de nuestro entorno para integrarnos con las comunidades cercanas.

4. Taller de Planificación participativa
A. Elementos de la planificación
B. El ciclo comunal
Organización para la ejecución de las obras
Coordinación de las tareas
Ejecución de las tareas
Evaluación de las tareas ejecutadas

Fonte: Campamento de Pioneros, Sala Técnica.

As atividades são iniciadas a partir da apresentação dos princípios e diretrizes do Campamento de Pioneros: Organización Autogestionaria, Planificación y Diseño Participativo, Producción Social, Aporte de Trabajo Familiar, e Propiedad Colectiva, assim como dos "valores fundamentais": Apoyo Mutuo, Respeto y Solidaridad e Participación y Liderazgo Colectivo.

As atividades utilizam como base as chamadas "10 funciones del organismo social": movimento, residência, produção, abastecimento, cuidado à saúde, proteção, educação, recreação, comunicação e organização. O trabalho a partir das 10 funções faz com que o processo de projeto da habitação parta do princípio da vivienda como o lugar para vivir integralmente: não é o resultado de um processo, mas o ponto de partida do processo.

Na sistematização da metodologia, são levantados diversos itens do resultado das atividades, entre os quais detacamos os seguintes exemplos:

"- Proponer como queremos vivir en nuestra Nueva Comunidad Socialista para revolucionar nuestra forma de vida;

- Ponernos en los zapatos de los demás, para entender los problemas del otro; 
- Concientizar la lucha de clases en nuestro proceso de construcción colectiva

- Relación y articulación con las comunidades adyacentes a la N.C.S.

- Debatir sobre el sistema político-económico que se nos ha impuesto (el capitalismo y democracia representativa)

- Debatir nuestros principios y todos los temas relacionados con la revolución bolivariana

- Fomentar procesos productivos y de intercambio comunes (practicar la economía socialista)

- Decidir que queremos como empresas de producción social (potencialidades urbanas)

- Ubicarnos dentro de un mapa,

- Saber donde están los demás campamentos

- Conocer las fortalezas y las debilidades en el movimiento del sector donde vivimos

- Identificar terrenos baldíos o sub-utilizados para plan parroquial.

- Participación activa y decisiva de los niños, se pueden trabajar metodologías especiales para los niños".

\section{As "10 funciones del organismo social".}
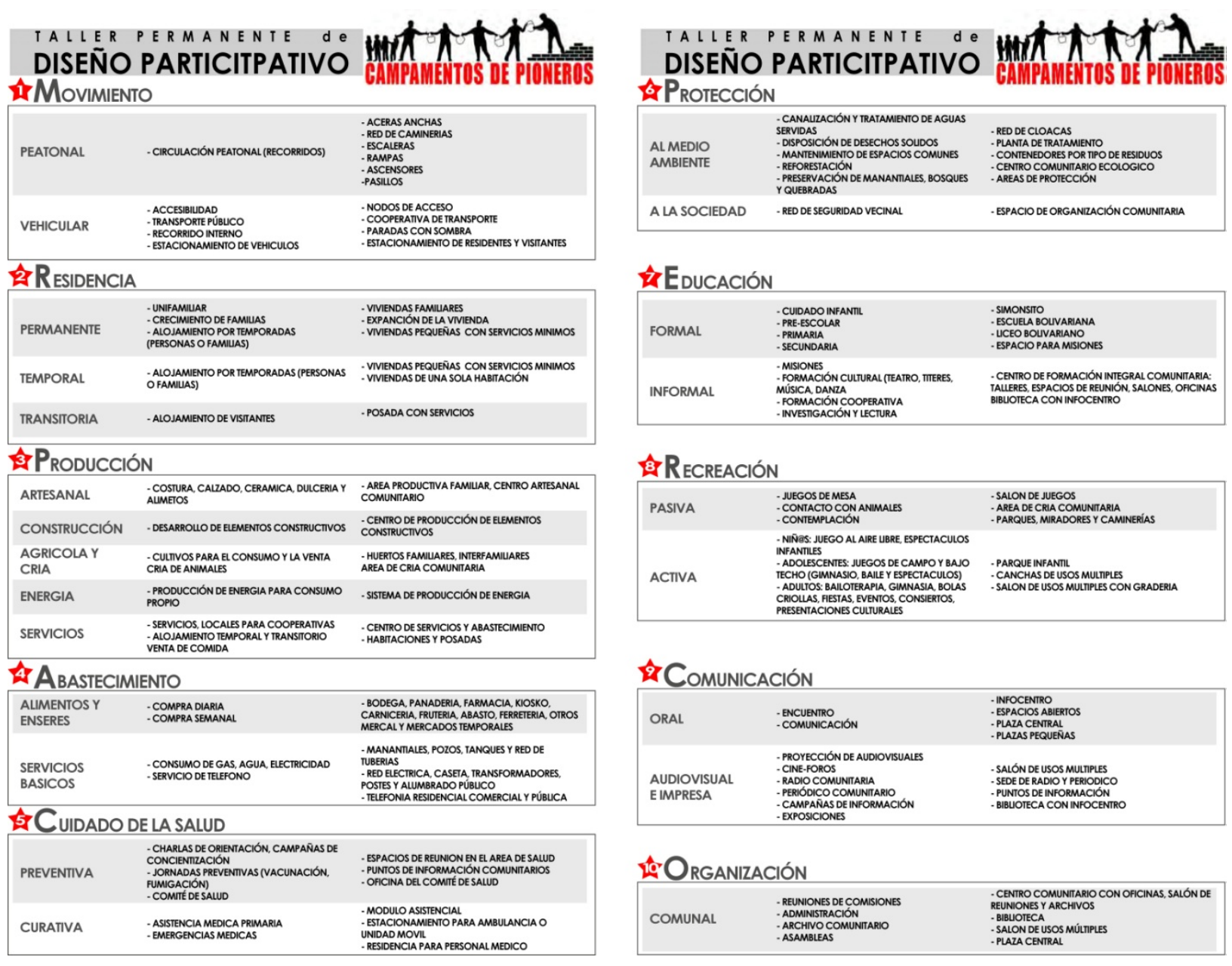

น̛̣OrGanización

\begin{tabular}{|c|c|c|}
\hline COMUNAL & $\begin{array}{l}\text {-REUNIONES DE COMMIIONES } \\
\text {-ADMNISTRCOCONN } \\
\text {-ARCIIIO COMUNIARIO } \\
\text {-ASAMBLEAS }\end{array}$ & $\begin{array}{l}\text { - CENTRO COMUNITARIO CON OFCINAS, SALÓN DE } \\
\text { REUNIONES Y ARCHIVOS } \\
\text {-BBIUOOECA } \\
\text {-SALN DE USOS MÚIIPLES } \\
\text { - PLAZA CENTRAL }\end{array}$ \\
\hline
\end{tabular}

Fonte: Campamento de Pioneros Sala Técnica. 
Uma das atividades realizadas a partir das 10 funções contrapõe o que seria uma cidade socialista e o que é a cidade capitalista. A provocação pela contraposição permite que o processo extrapole os reduzidos limites normalmente colocados no projeto habitacional. A conjuntura política da Venezuela atual, no qual a transição ao socialismo é tida como um objetivo real, favorece esse tipo de atividade e introduz na dinâmica de projeto arquitetônico a ousadia muitas vezes deixada de lado em projetos de habitação de interesse social. Cláudio Nascimento nos lembra que o contrário da utopia não é a realidade, é o pragmatismo.

\begin{tabular}{|c|c|c|}
\hline & $\begin{array}{l}\text { Modelo Capitalista de ocupación territorial } \\
\text { Ciudad dispersa, funcionalista y excluyente }\end{array}$ & $\begin{array}{l}\text { Modelo Socialista de ocupación territorial. } \\
\text { Ciudad compacta, diversa e incluyente }\end{array}$ \\
\hline Movimiento & $\begin{array}{l}\text { Impone la necesidad de movernos solo con vehículos } \\
\text { privados (carros, motos, camionetas). Priorizando la vialidad } \\
\text { vehicular en la estructura urbana (calles, avenidas y } \\
\text { autopistas). }\end{array}$ & $\begin{array}{l}\text { Necesidad de movernos de un sitio a otro, por medio de un } \\
\text { sistema integral de movilidad (transporte publico, ciclo vías, } \\
\text { bulevares, calles incluyentes), priorizando la movilidad } \\
\text { peatonal y colectiva. }\end{array}$ \\
\hline Residencia & $\begin{array}{l}\text { Modelo de vivienda aislada que acentúa el individualismo, } \\
\text { generando espacios aislados con un solo uso } \\
\text { (urbanizaciones), diferenciando su rentabilidad según } \\
\text { "clases sociales" (especulación inmobiliaria, exclusión) }\end{array}$ & $\begin{array}{l}\text { Modelo de vivienda compacta que refuerza la convivencia } \\
\text { en colectivo, generando espacios comunes de contacto, } \\
\text { intercambio y comunicación. Promoviendo diversidad de } \\
\text { usos y conjuntos habitacionales integrales e incluyentes. }\end{array}$ \\
\hline Producción & $\begin{array}{l}\text { Concentración de usos industriales y comerciales en áreas } \\
\text { urbanas desvinculadas de su contexto, ocupando grandes } \\
\text { espacios en áreas privilegiadas de la ciudad. }\end{array}$ & $\begin{array}{l}\text { Modelo de ciudad productiva diversa e integral, que } \\
\text { distribuye el sistema de producción de manera equitativa e } \\
\text { incluyente. }\end{array}$ \\
\hline Abastecimiento & $\begin{array}{l}\text { Centralización de los sistemas de abastecimiento de } \\
\text { alimentos y enceres en grandes cadenas especulativas. } \\
\text { Privatización de los senvicios fundamentales de uso diario } \\
\text { (agua, luz, teléfono, etc.) y distribución desequilibrada. }\end{array}$ & $\begin{array}{l}\text { Desconcentración del sistema de abastecimiento en redes } \\
\text { de distribución popular e integral. Servicios públicos } \\
\text { distribuidos equitativamente en toda la ciudad. }\end{array}$ \\
\hline Salud & $\begin{array}{l}\text { Priorización y privatización de la salud curafiva, en grandes } \\
\text { centros de salud excluyentes. }\end{array}$ & $\begin{array}{l}\text { Desconcentración del sistema de salud publica, enfatizando } \\
\text { la prevención y garantizando la inclusión. }\end{array}$ \\
\hline Protección & $\begin{array}{l}\text { No genera mecanismos de protección ambiental nisocial y } \\
\text { refuerza la destrucción del ambiente y de la sociedad. }\end{array}$ & $\begin{array}{l}\text { Impulsa mecanismos de protección ambiental (quebradas, } \\
\text { vegetación y geológico) generando el menor impacto } \\
\text { posible }\end{array}$ \\
\hline Educación & $\begin{array}{l}\text { Privatización del sistema educafivo formal, excluyendo } \\
\text { buena parte de la sociedad. }\end{array}$ & $\begin{array}{l}\text { Garantiza los medios para la educación formal e informal, } \\
\text { sin exclusión. }\end{array}$ \\
\hline Comunicación & $\begin{array}{l}\text { Castración de los mecanismos para la recreación, la } \\
\text { comunicación y la organización social, Privatizándolos y } \\
\text { parcializándolos en sectores excluyentes de la ciudad. }\end{array}$ & $\begin{array}{l}\text { Garantiza los espacios y los medios para la organización } \\
\text { comunal, recreación y comunicación integral, generando } \\
\text { mecanismo para la participación de los sujetos politicos. }\end{array}$ \\
\hline & & \\
\hline
\end{tabular}

Uma das atividades é realizada junto às crianças, que partem da proposta de desenhar "minha casa hoje, minha casa amanhã".

Desenhos preciosos são realizados pelas crianças, mostrando os detalhes das casas, como vasos, penteadeiras, lugar para guardar os sapatos, o lugar da televisão na casa, ou o desejo por janelas com vista para a rua, formando um mosaico vibrante composto por representações em planta e vista livremente misturadas.

A percepção do espaço pela criança é nitidamente diferente dos adultos, diante do uso diferente do espaço no cotidiano, da posição da criança na casa, do uso muitas vezes menos utilitário e mais lúdico de determinados espaços, etc. Mas assim como a criança apresenta outra forma de se relacionar e perceber o espaço, o mesmo ocorre com a mulher em relação ao homem, ou com o idoso em relação aos membros mais jovens da família. Não tivemos contato com atividades que trabalhassem todas essas relações 
sociais. Em atividades junto aos Campamentos, realizamos apresentações de nossa experiência no Brasil, com exemplo de atividades de projeto que abordavam a diferença do espaço vivido e pensado pela mulher e pelo homem, pelos idosos e pelos jovens.

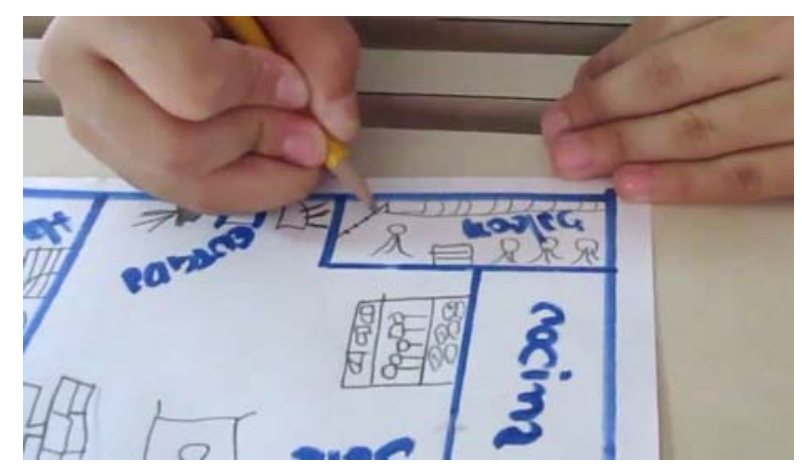

"En el balcón quero que haya una vista hasta la calle y una ventanita donde se ve hacia la sala".

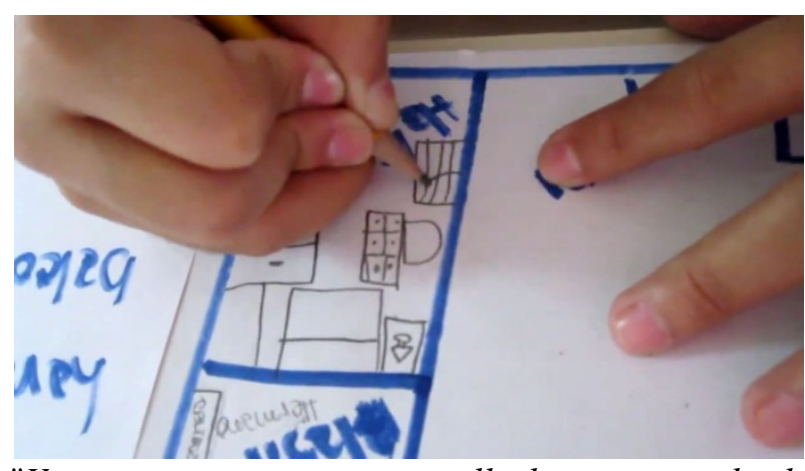

"Y va tener una ventana, a ella le gusta mucho la ventana. Una ventana grandísima, con su cortina".

"Mi Casa Mañana" de Gabriela Castro.

Fonte: Vídeo realizado por Juan Velásquez, em https://vimeo.com/femsusdev, acessado em dezembro de 2014.

A atividade "minha casa hoje, minha casa amanhã" é realizada também com adultos. O desenhos são então analisados com o objetivo de extrair as principais lógicas internas da casa existente e da casa desejada, como a relação entre os cômodos, as características mais importantes da sala, da cozinha, etc.

Uma interessante metodologia de projeto participativo se baseia na idéia de Coração da Nova Comunidade Socialista. Esta atividade parte da sistematização do programa de necessidades trabalhado nas atividades anteriores, com o agrupamento em grandes grupos de espaços (unidades). No exemplo abaixo, foram formados 8 grupos: residencial, transporte, casa comunal, abastecimento, ecologia, produção, educação-recreação e festa. A partir da formação desses grandes grupos, cada família preenche uma tabela, indicando o nível de proximidade desejável entre cada um dos grupos (entre 0 e 2, sendo 0 mais afastado e 2 mais próximo). A partir da sistematização das respostas, se consolida uma matriz de relações, na qual cada unidade soma uma certa quantidade de pontos. As unidades com maior quantidade de pontos são aquelas que maior relação de proximidade com as outras unidades, e portanto serão consideradas como o Coração da Nova Comunidade. A partir desse momento, o projeto do conjunto será pensando a partir dessas unidades, no exemplo abaixo, as unidades Transporte e Produção. 


\section{Balange Metología Apligadade dseño pabtigipativo}

\section{UNIDADES AGRUPADAS EL CORAZON DE LA NCS}
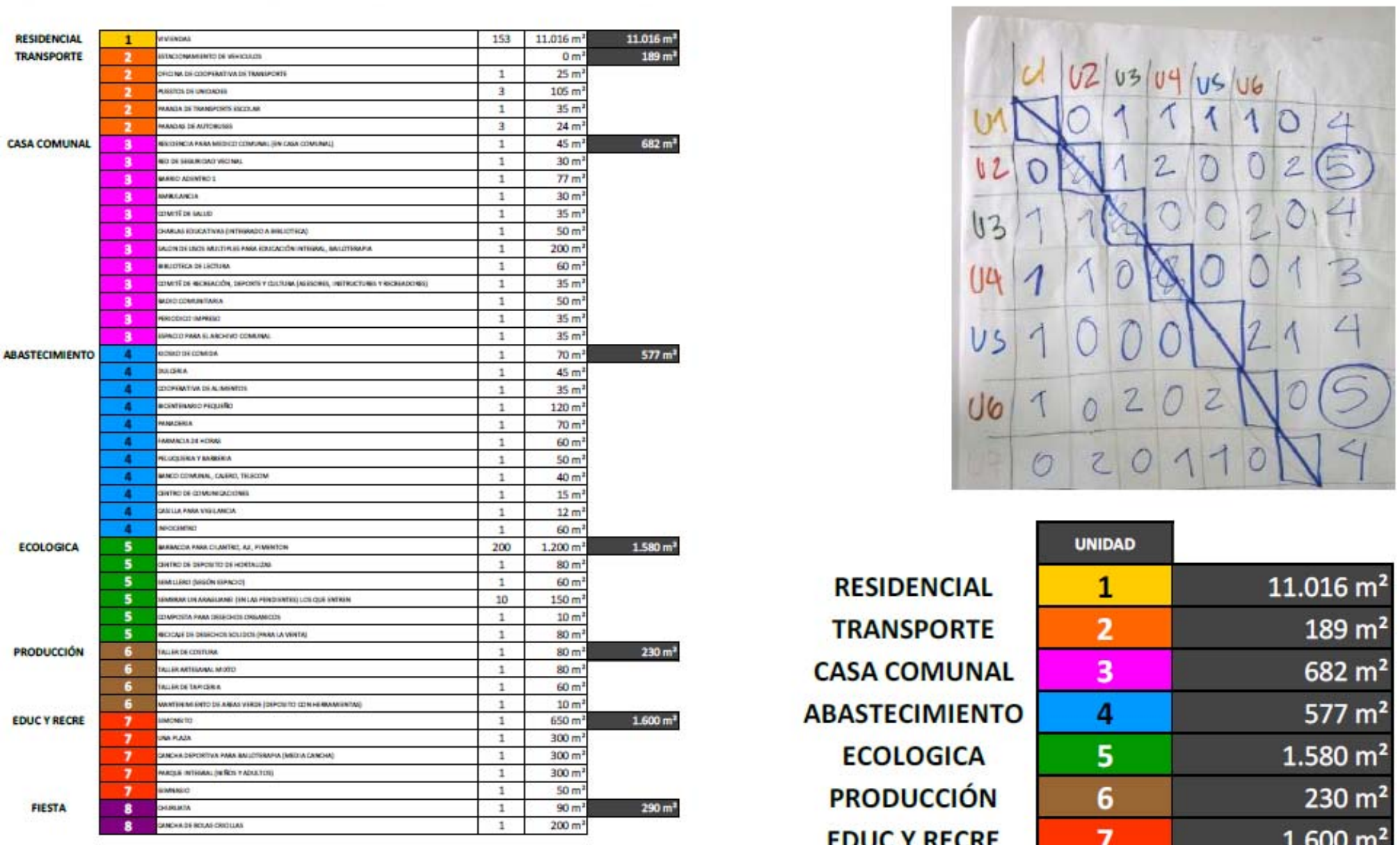

wat +1

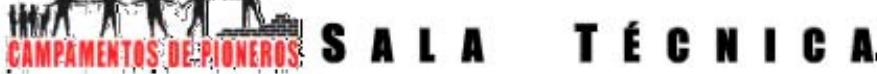

\begin{tabular}{c|c|r}
\cline { 2 - 3 } & \multicolumn{1}{|c|}{ UNIDAD } & \\
\cline { 2 - 3 } RESIDENCIAL & 1 & $11.016 \mathrm{~m}^{2}$ \\
\cline { 2 - 3 } TRANSPORTE & 2 & $189 \mathrm{~m}^{2}$ \\
\cline { 2 - 3 } CASA COMUNAL & 3 & $682 \mathrm{~m}^{2}$ \\
\cline { 2 - 3 } ABASTECIMIENTO & 4 & $577 \mathrm{~m}^{2}$ \\
\cline { 2 - 3 } ECOLOGICA & 5 & $1.580 \mathrm{~m}^{2}$ \\
\cline { 2 - 3 } PRODUCCIÓN & 6 & $230 \mathrm{~m}^{2}$ \\
\cline { 2 - 3 } EDUC Y RECRE & 7 & $1.600 \mathrm{~m}^{2}$ \\
\cline { 2 - 3 } FIESTA & 8 & $290 \mathrm{~m}^{2}$ \\
\cline { 2 - 3 } & &
\end{tabular}




\section{Ba A I GE Metología Apliganade dseño pantigipativo}

\section{NCS Amatina}

DEBATE, CUANTIFICACIÓN Y ESPACIALIZACIÓN DE LAS PROPUESTAS

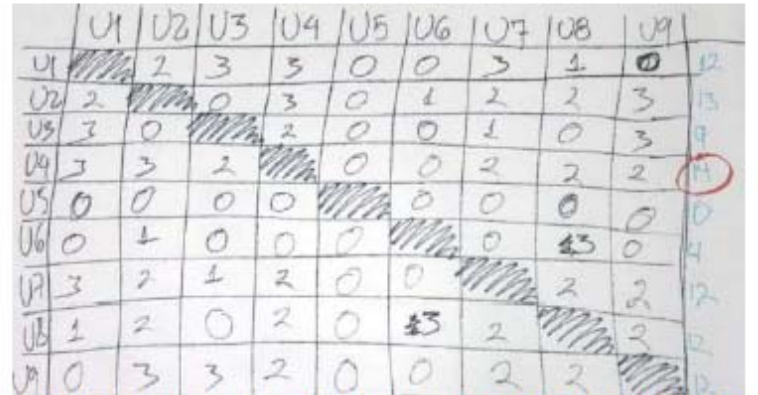

MATRIZ DE RELACIONES (CORAZON DE LA NCS)

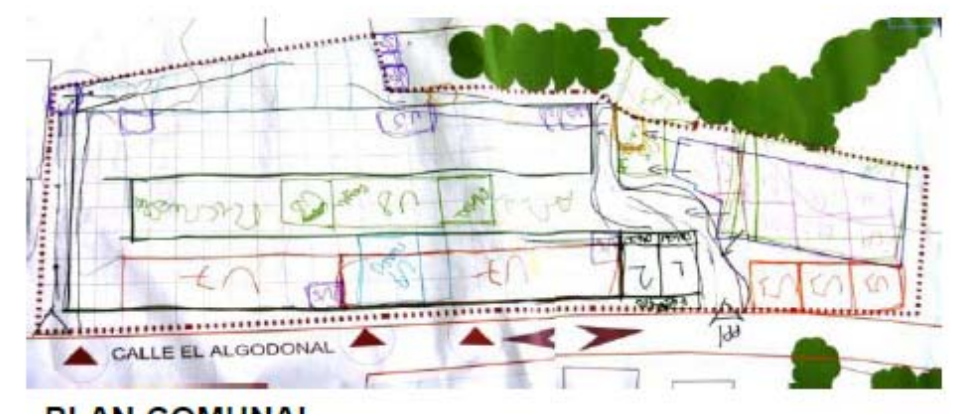

PLAN COMUNAL

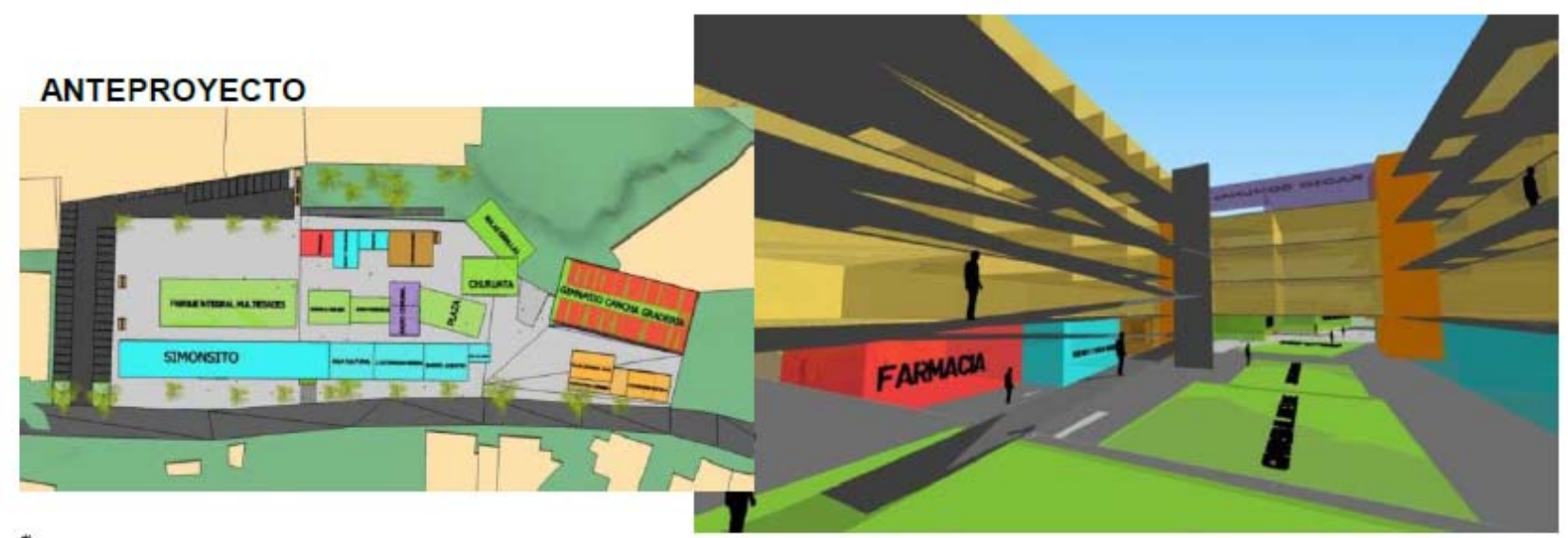

Wht $+1 \mathrm{x}$

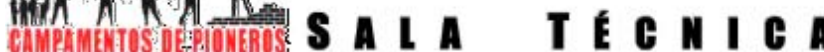

Projeto Participativo da Nueva Comunidad Socialista Amatina.

Fonte: Campamento de Pioneros, Sala Técnica. 
Em diversas oportunidades apresentamos a metodologia utilizada pela Usina na qual iniciamos o projeto participativo pela unidade habitacional, por meio de móveis representados em escala 1:20 (nota); a partir da montagem de unidades habitacionais partimos para o projeto da implantação. Trata-se de um caminho inverso àquele que parte do coração da comunidade (implantação) para então iniciar o desenho do edifício habitacional. Os Pioneros realizaram experiências com a metodologia que parte da unidade habitacional; o caminho que parte do coração, no entanto, teve melhores resultados. O contexto político talvez explique a diferença.

\section{As Nuevas Comunidades Socialistas}

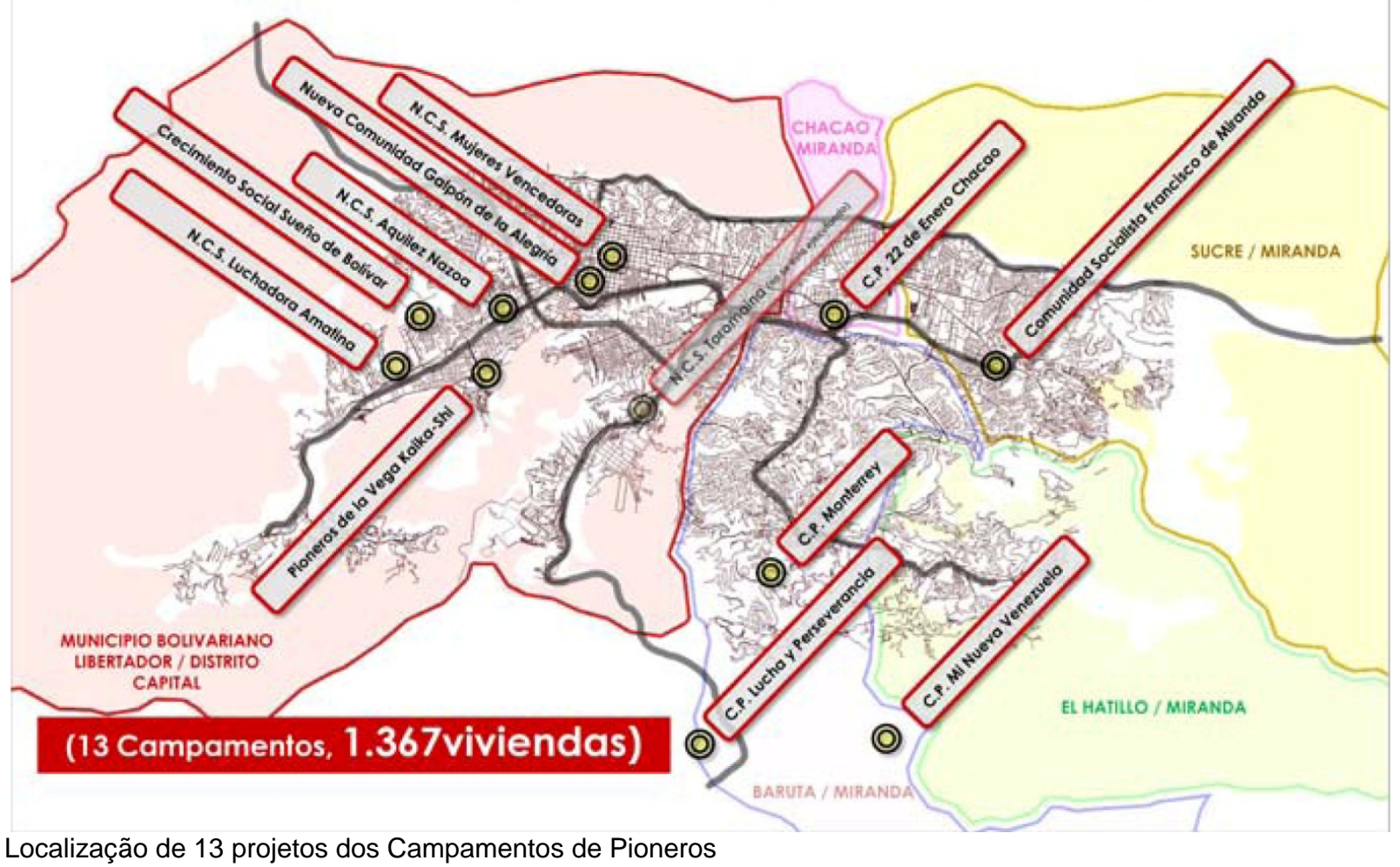

Fonte: Campamento de Pioneros, Sala Técnica.

Ao menos 6 Campamentos de Pioneros foram batizados com nomes de mulheres lutadoras da história da Venezuela ou fazem referência direta à participação da mulher na luta pela moradia, como Mujeres Vencedoras, Mujeres Luchadoras, Luchadora Amatina. Madre Hipólita faz referência à escrava que cuidou de Simón Bolívar, conhecida normalmente como Negra Hipólita. Eulalia Buroz e Luisa Cáceres foram combatentes durante a guerra de independência. Próximas a Bolívar e outros próceres, seus nomes são pouco lembrados se comparados aos combatentes homens. Manuelita Saénz, nascida no Equador e conhecida como a "libertadora do libertador", em razão de sua defesa à Bolívar durante um ataque, 
chega a ser considerada por alguns como a primeira feminista da América Latina ${ }^{52}$. Negra Matea foi uma escrava propriedade da família de Simón Bolívar.

A maioria das Nuevas Comunidades Socialistas se localizam em terrenos próximos às favelas. A Nueva Comunidad Socialista Aquiles Nazoa nasceu a partir de um CTU formado na favela El Guarataro em 2002. Segundo a Agencia Venezolana de Noticias, "algunas de las acciones que han impulsado es un inventario de terrenos ociosos, abandonados o subutilizados en la parroquia que puedan ser destinados a proyectos habitacionales. Hoy suman, aseguran, 74 predios sin uso o de uso no conforme" ${ }^{\text {"53 }}$. Um dos terrenos descobertos, com $3.145 \mathrm{~m}^{2}$, era de propriedade do Ministerio del Poder Popular para el Ambiente. Reivindicado pela comunidade, o terreno foi repassado ao Ministerio de Vivienda y Habitat e então disponibilizado ao Campamentos de Pioneros.

A organização de Pioneros a partir de grupos cujos integrantes apresentam algumas características em comum não se limita apenas às mulheres. Um dos grupos, batizado de Jóvenes en Revolución, é formado basicamente por homens jovens. Também um grupo de transsexuais está se reunindo na tentativa de formação de um novo grupo de Pioneros.

\section{Nueva Comunidad Socialista Francisco de Miranda}

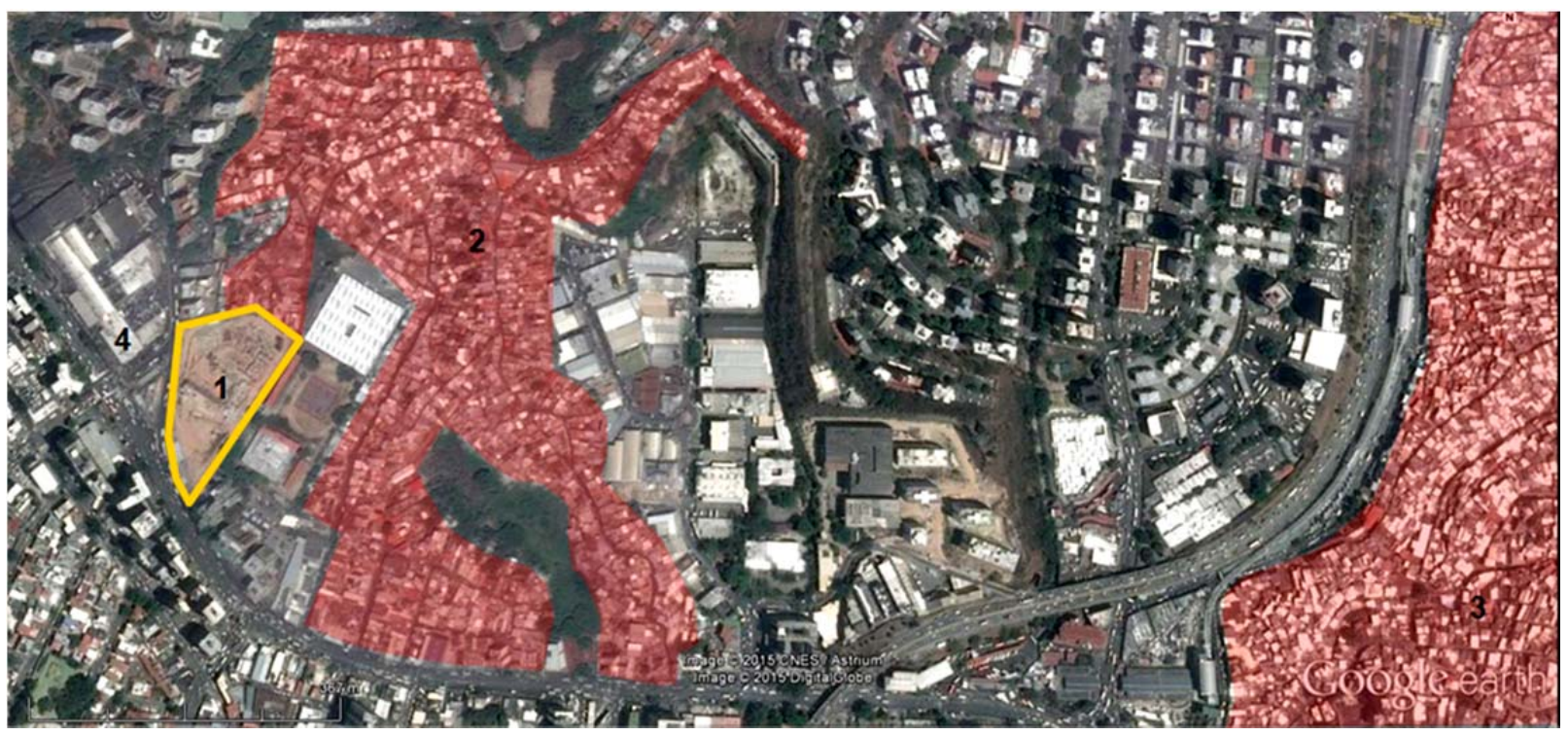

1. Nueva Comunidad Socialista Francisco de Miranda. 2. Favela 3. Favela do Petare; 4. Estação de Metrô La California.

\footnotetext{
52 "Manuela Sáenz: Primera Feminista de América Latina" em http://www.minmujer.gob.ve.

53125 familias de San Juan crearán comunidad socialista en terreno transferido por el Estado Caracas, 11 May. AVN
} 


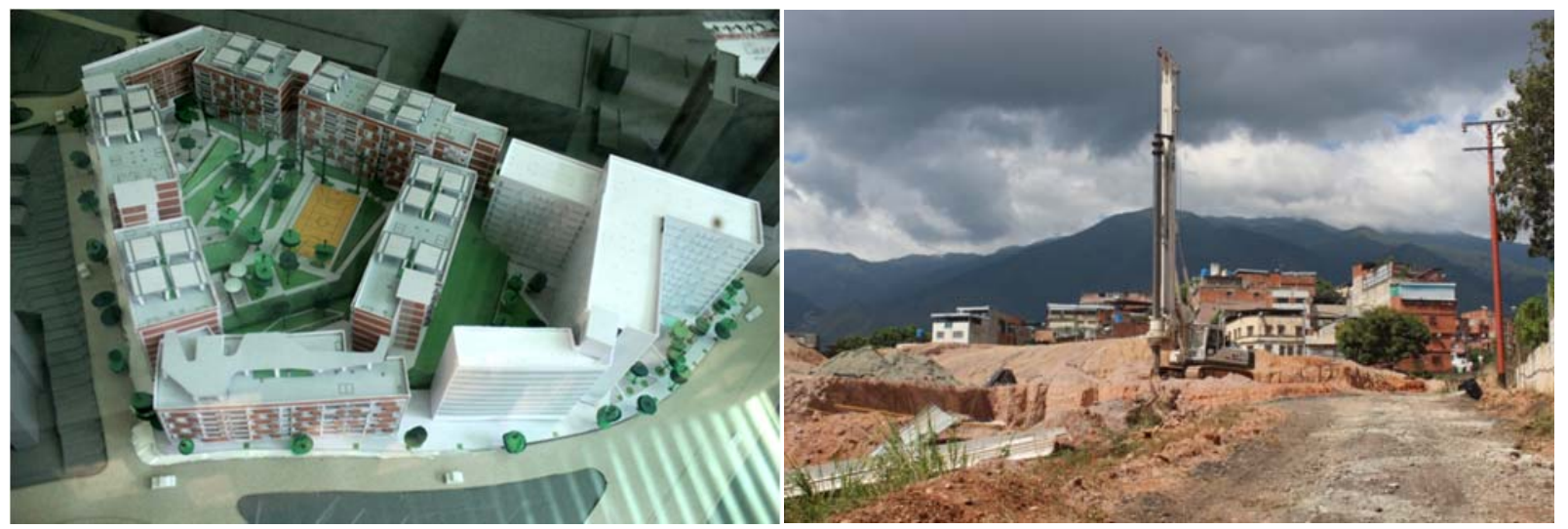

Fig. 76: Maquete da Nueva Comunidad Socialista Francisco de Miranda, com proposta de doação da frente do terreno para praça; Fig. 77: Construção da Nueva Comunidad Socialista Francisco de Miranda, em primeiro plano a máquina cedida pelo governo e ao fundo a favela onde moram as famílias que conformam o coletivo.

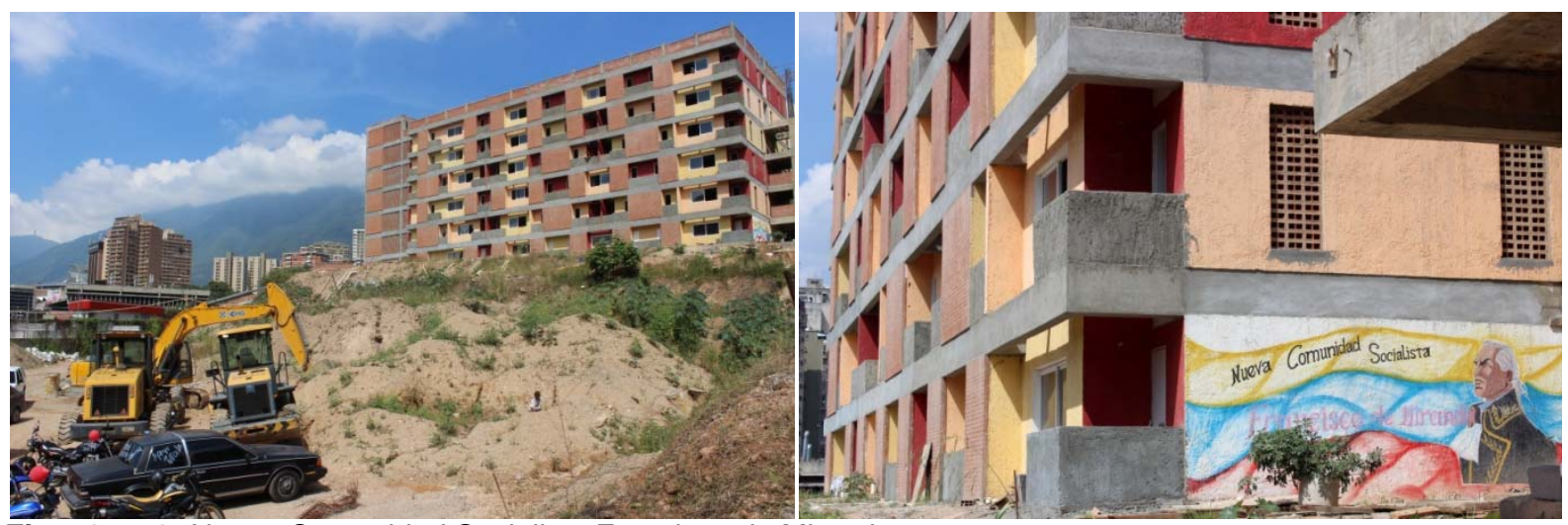

Fig. 78 e 79: Nueva Comunidad Socialista Francisco de Miranda

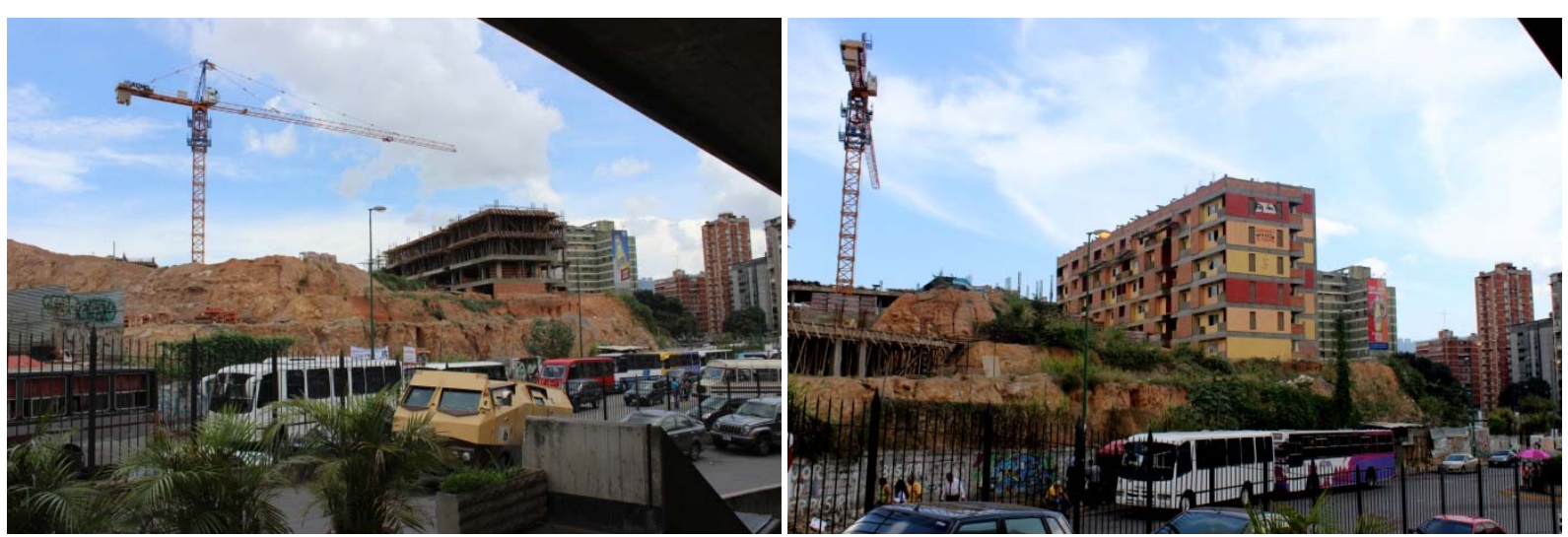

Fig. 80 e 81: Nueva Comunidad Socialista Francisco de Miranda 


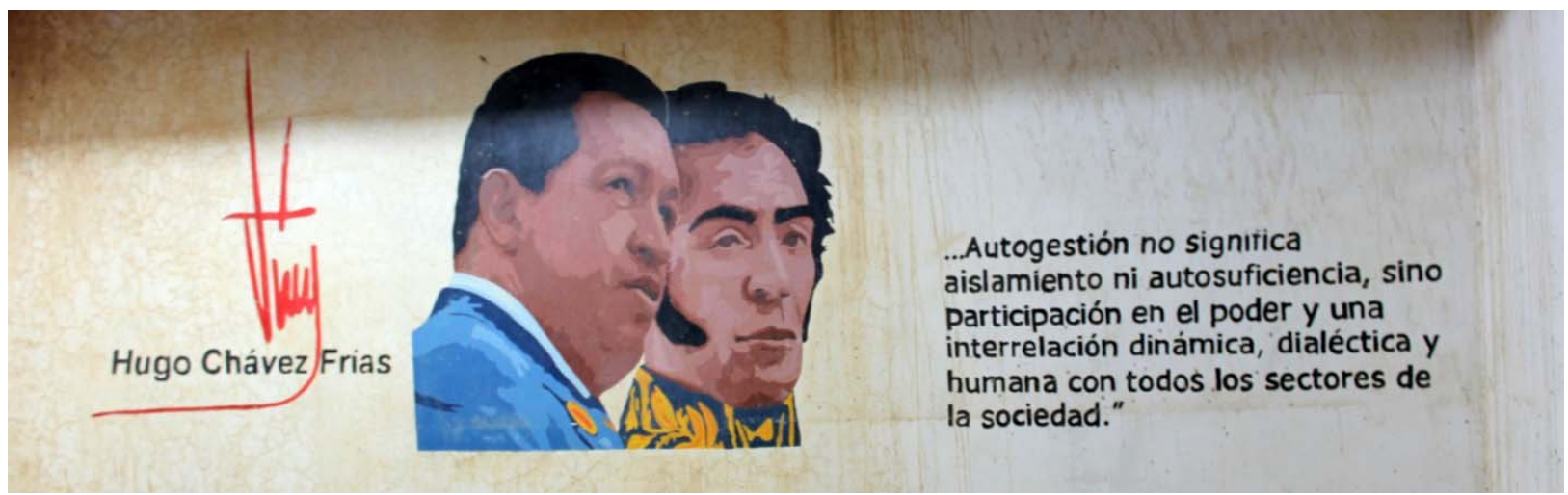

Fig. 82: Interior de edifício da Nueva Comunidad Socialista Francisco de Miranda

\section{Nueva Comunidad Socialista Mujeres Vencedoras}

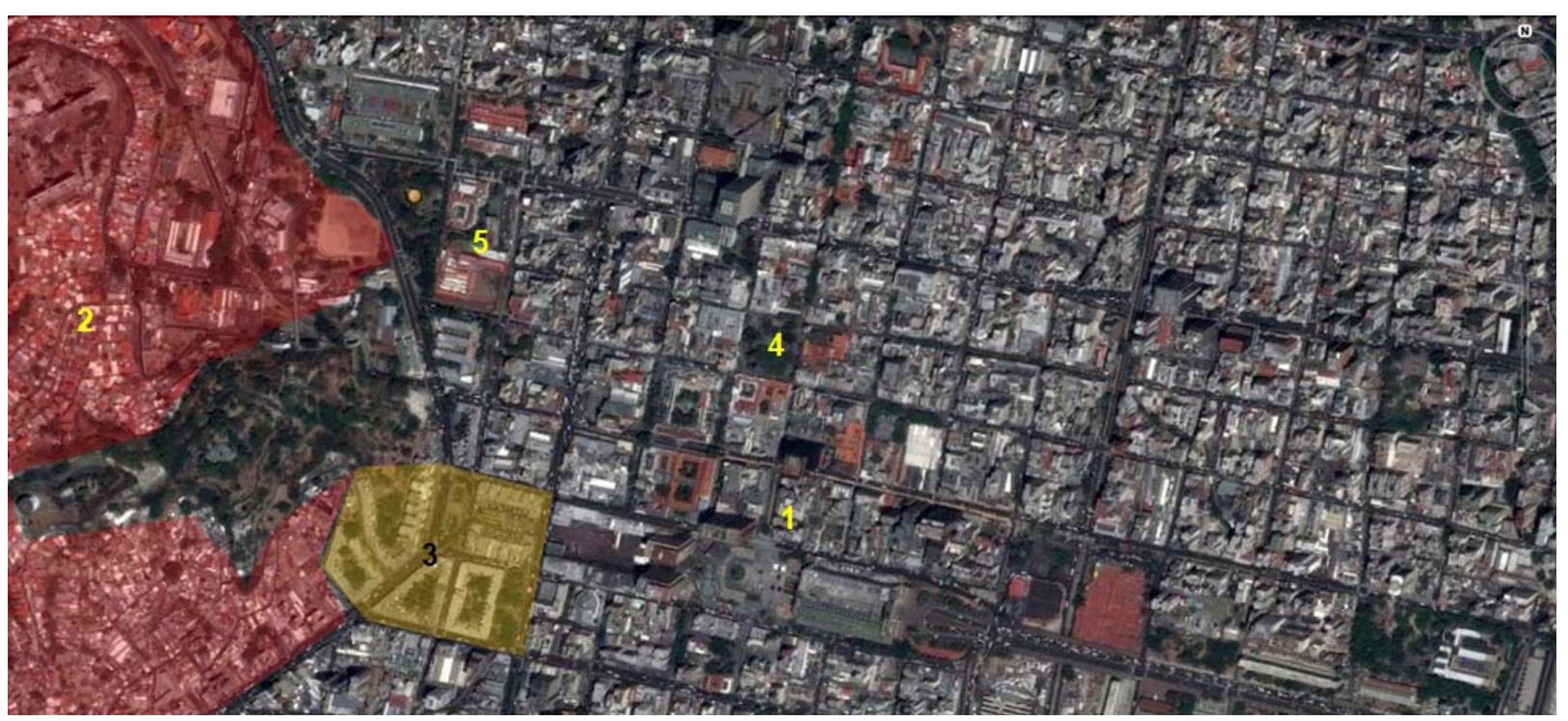

1. Nueva Comunidad Socialista Mujeres Vencedoras; 2. Favela 23 de Enero; 3. Reurbanización El Silencio; 4. Plaza Bolívar; 5. Palácio de Miraflores.
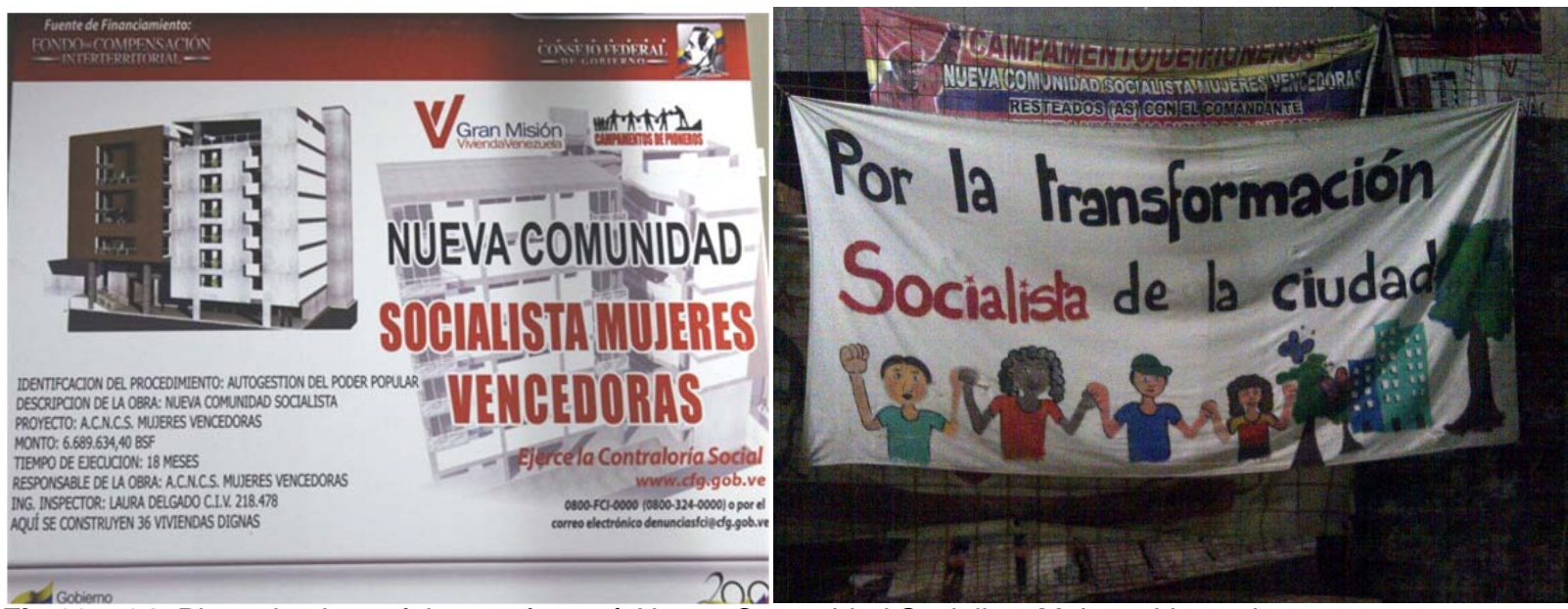

Fig 83 e 84: Placa de obra e faixa em frente à Nueva Comunidad Socialista Mujeres Vencedoras 

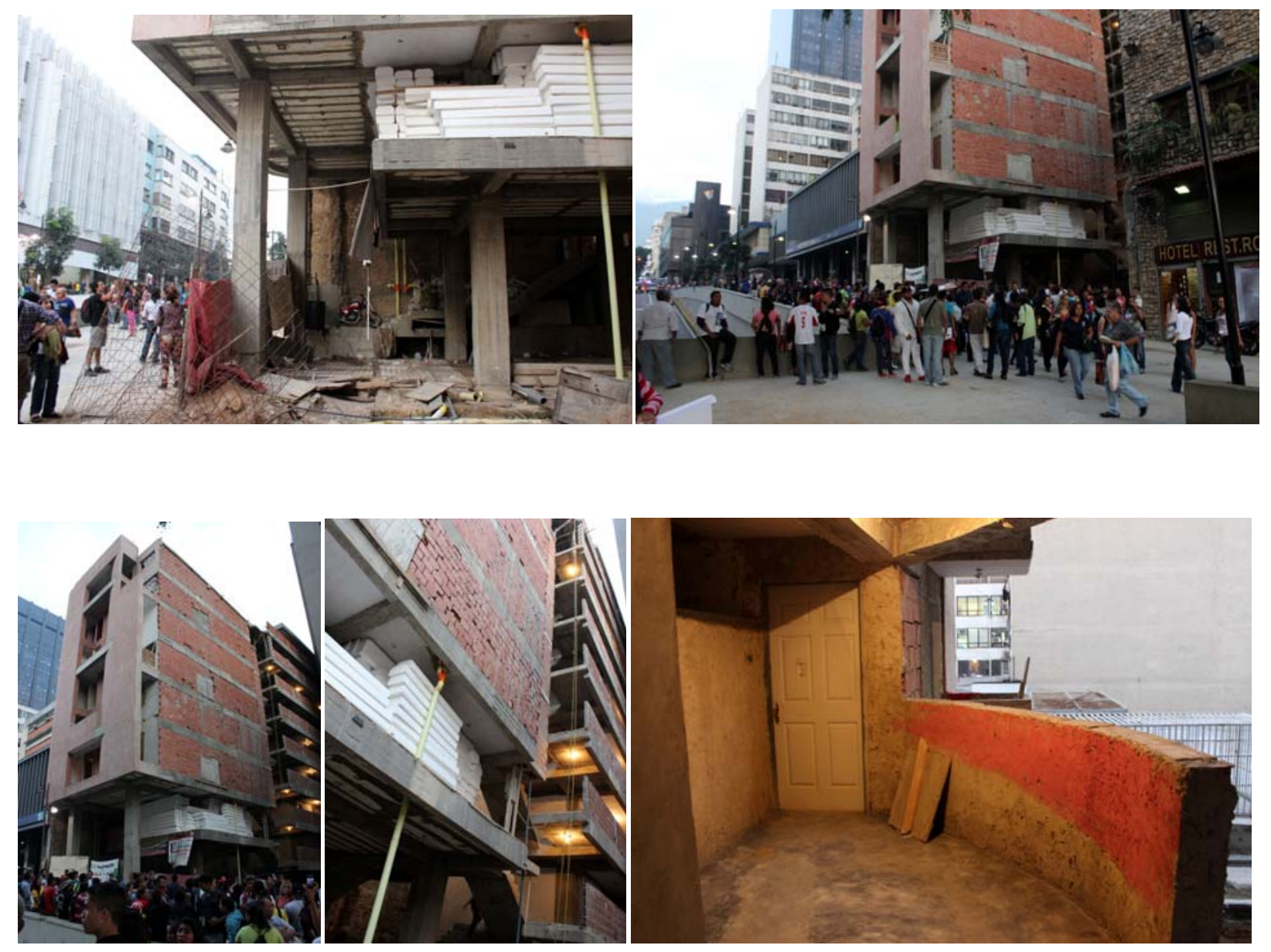

Fig. 85 a 89: Nueva Comunidad Socialista Mujeres Vencedoras 


\section{Nueva Comunidad Socialista Luchadoras Amatina}

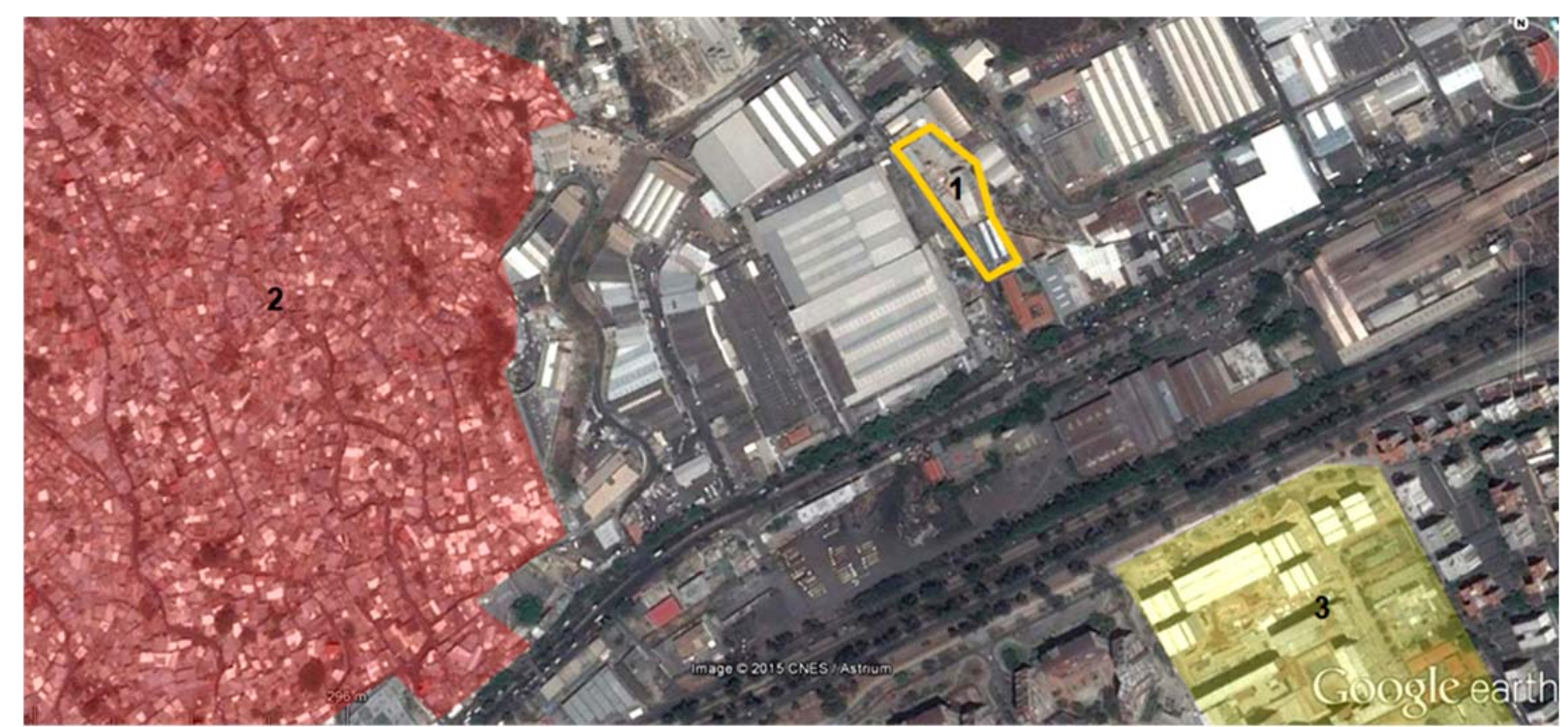

1. Nueva Comunidad Socialista Luchadoras Amatina; 2. Favela; 3. Gran Misión Vivienda Venezuela.

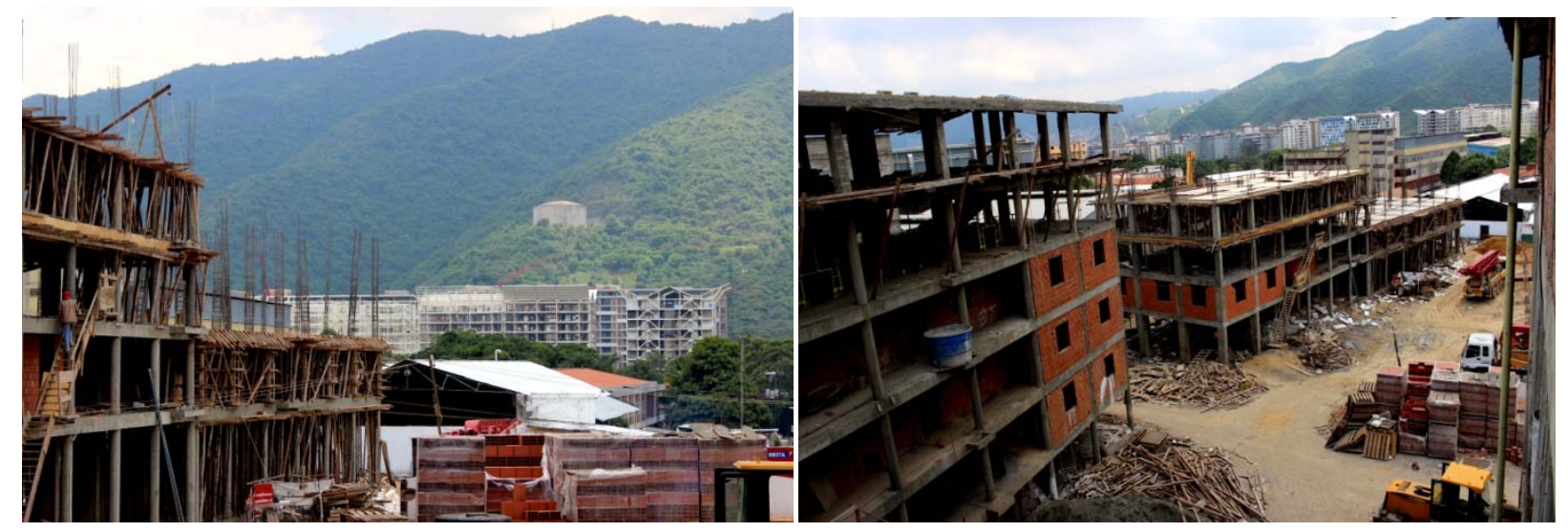

Fig. 90 e 91: Nueva Comunidad Socialista Luchadoras Amatina - ao fundo empreendimento GMVV.

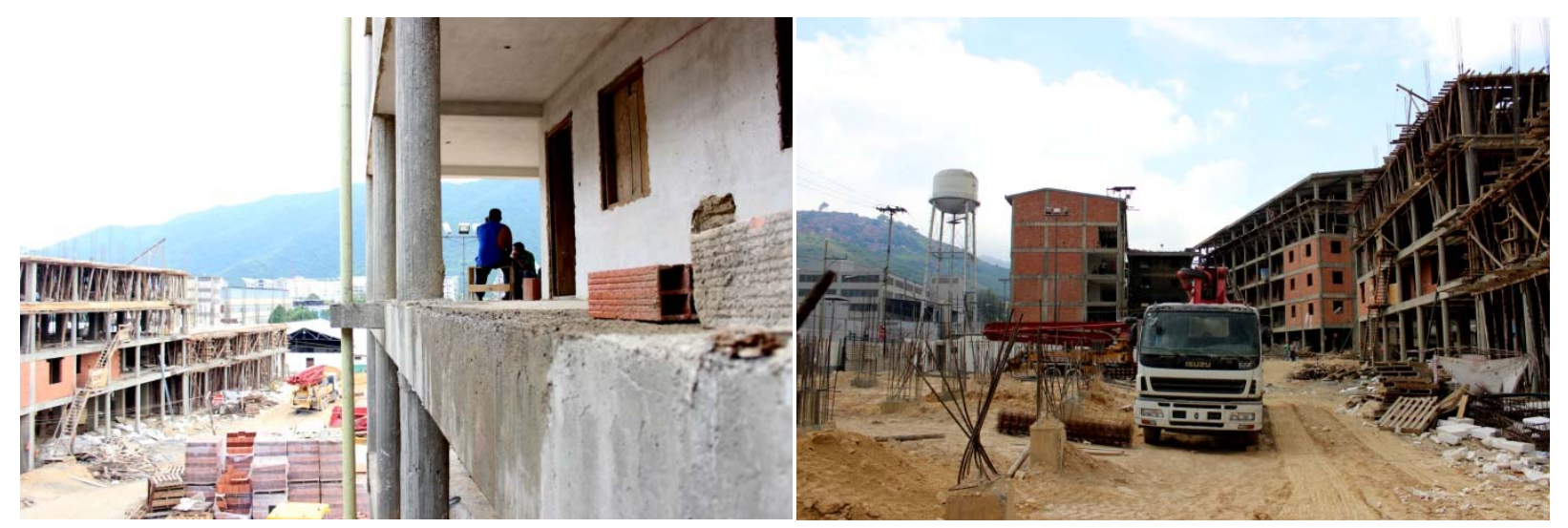

Fig. 92 e 93: Nueva Comunidad Socialista Luchadoras Amatina. 


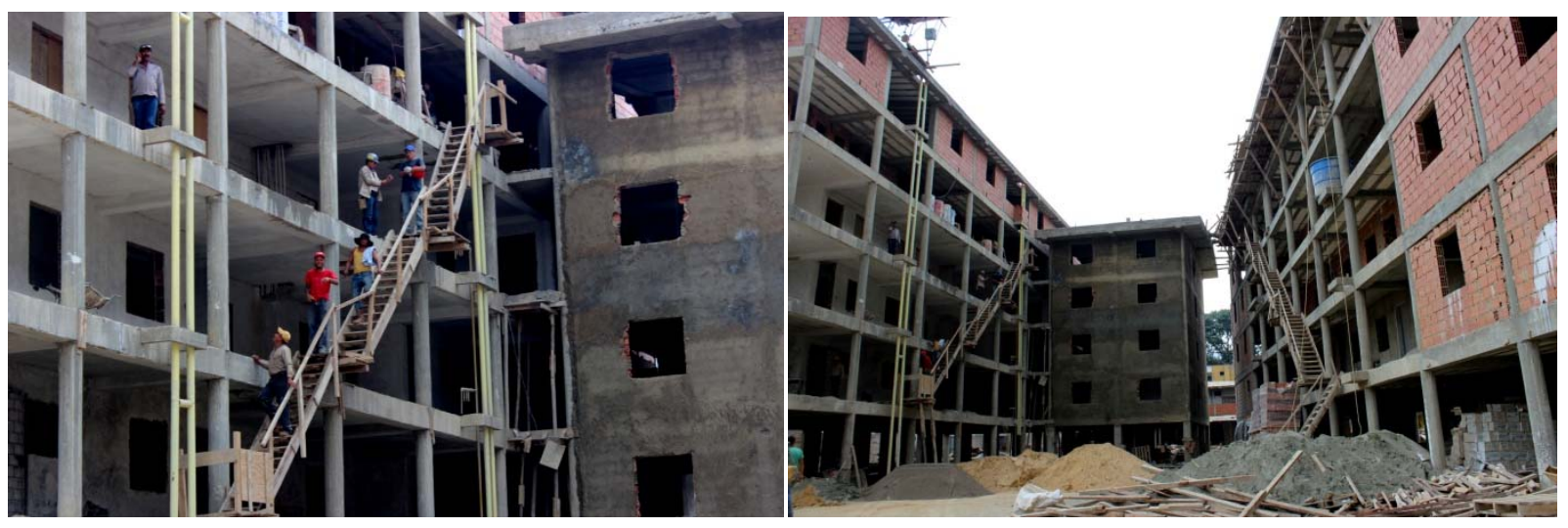

Fig. 94 e 95: Nueva Comunidad Socialista Luchadoras Amatina.
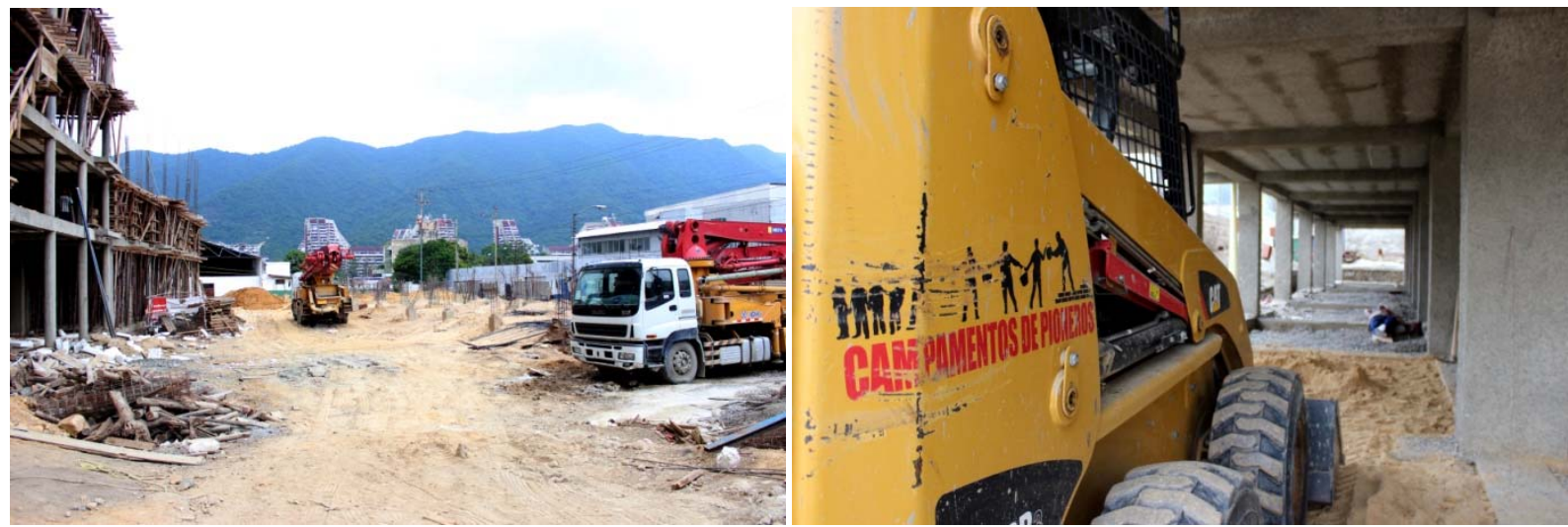

Fig. 96: Nueva Comunidad Socialista Luchadoras Amatina. Fig. 97: Equipamento cedido pelo governo ao movimento.

\section{Nueva Comunidad Socialista Aquiles Nazoa}

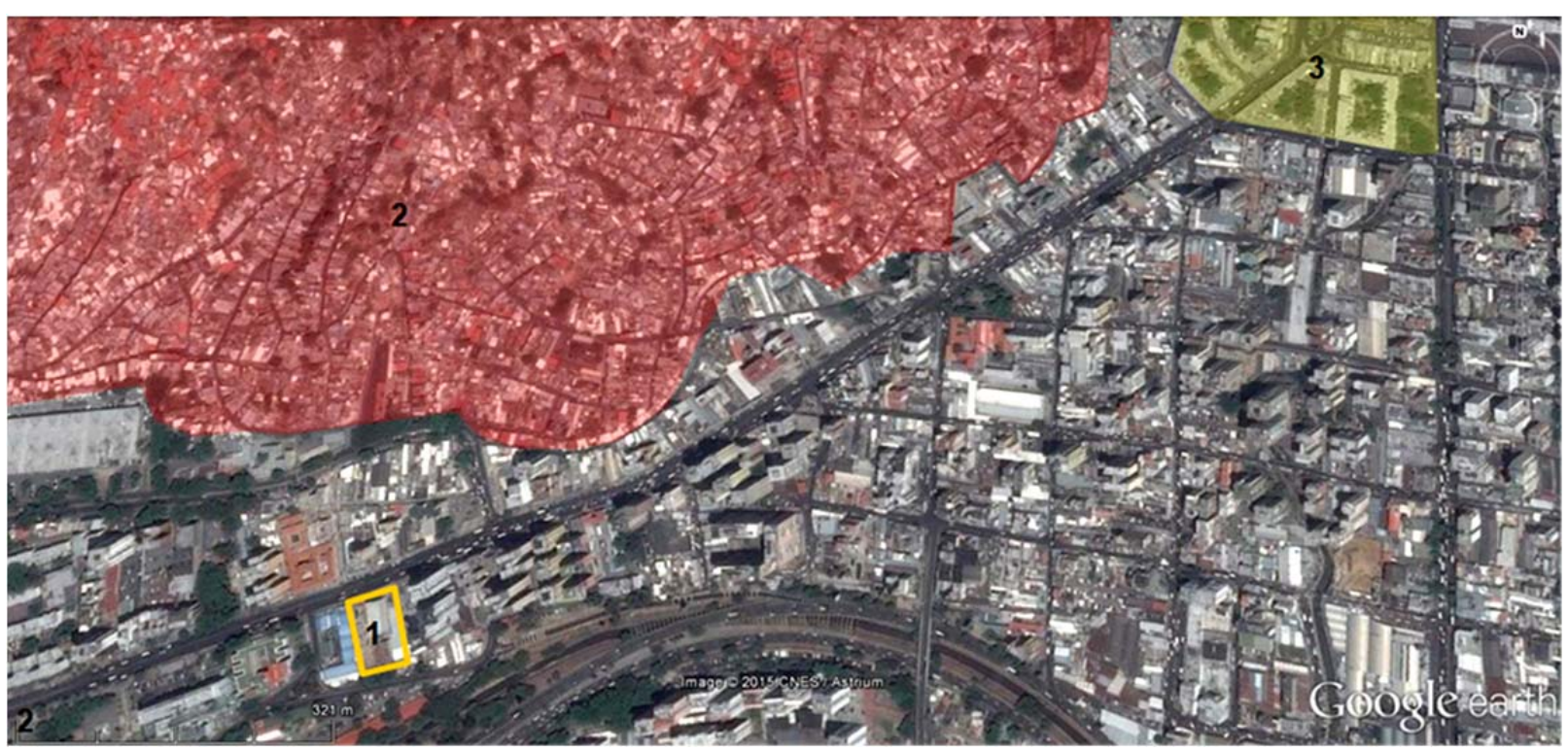

1. Nueva Comunidad Socialista Aquiles Nazoa; 2. Favela; 3. Reurbanización El Silencio. 


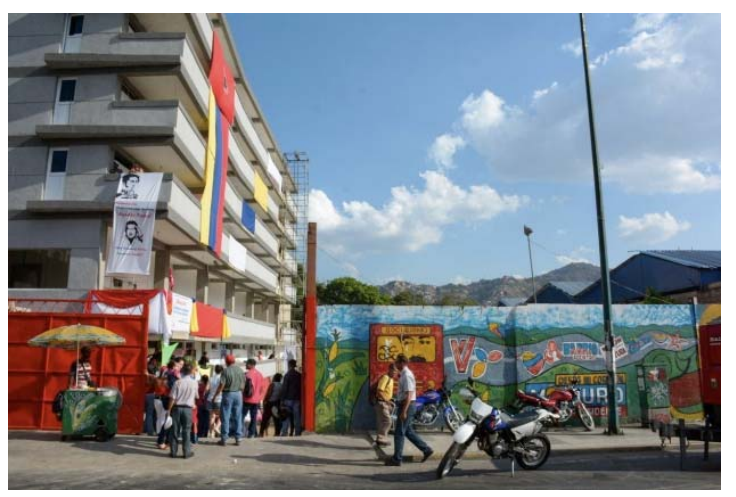

Fig. 98: Nueva Comunidad Socialista Aquiles Nazoa

\section{Nueva Comunidad Socialista 22 de Enero}

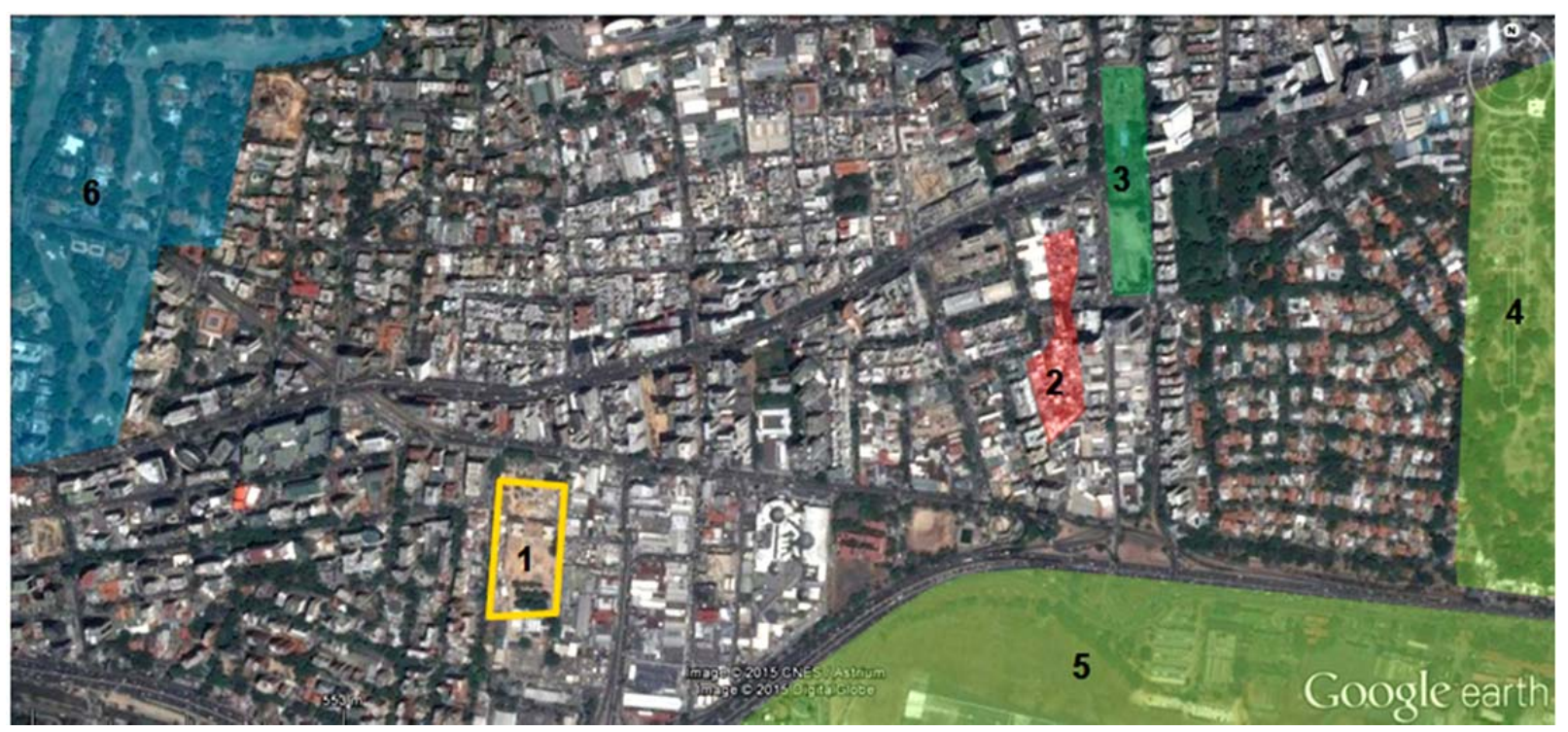

1. Nueva Comunidad Socialista 22 de Enero; 2. Favela; 3. Plaza Francia - Plaza Altamira; 4. Parque Francisco de Miranda; 5. Aeroporto La Carlota (futuro parque), 6. Country Club (clube de golf).
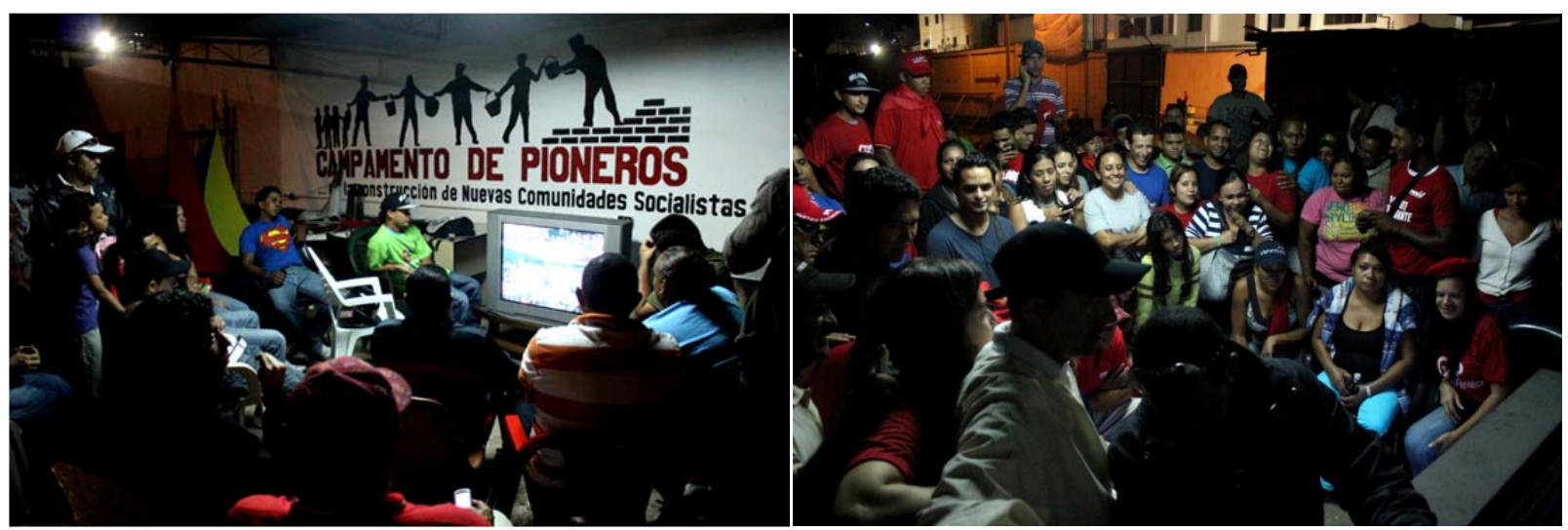

Fig. 99 e 100: Campamento de Pioneros 22 de Enero - minutos antes do anúncio da vitória de Hugo Chávez em 2012. 


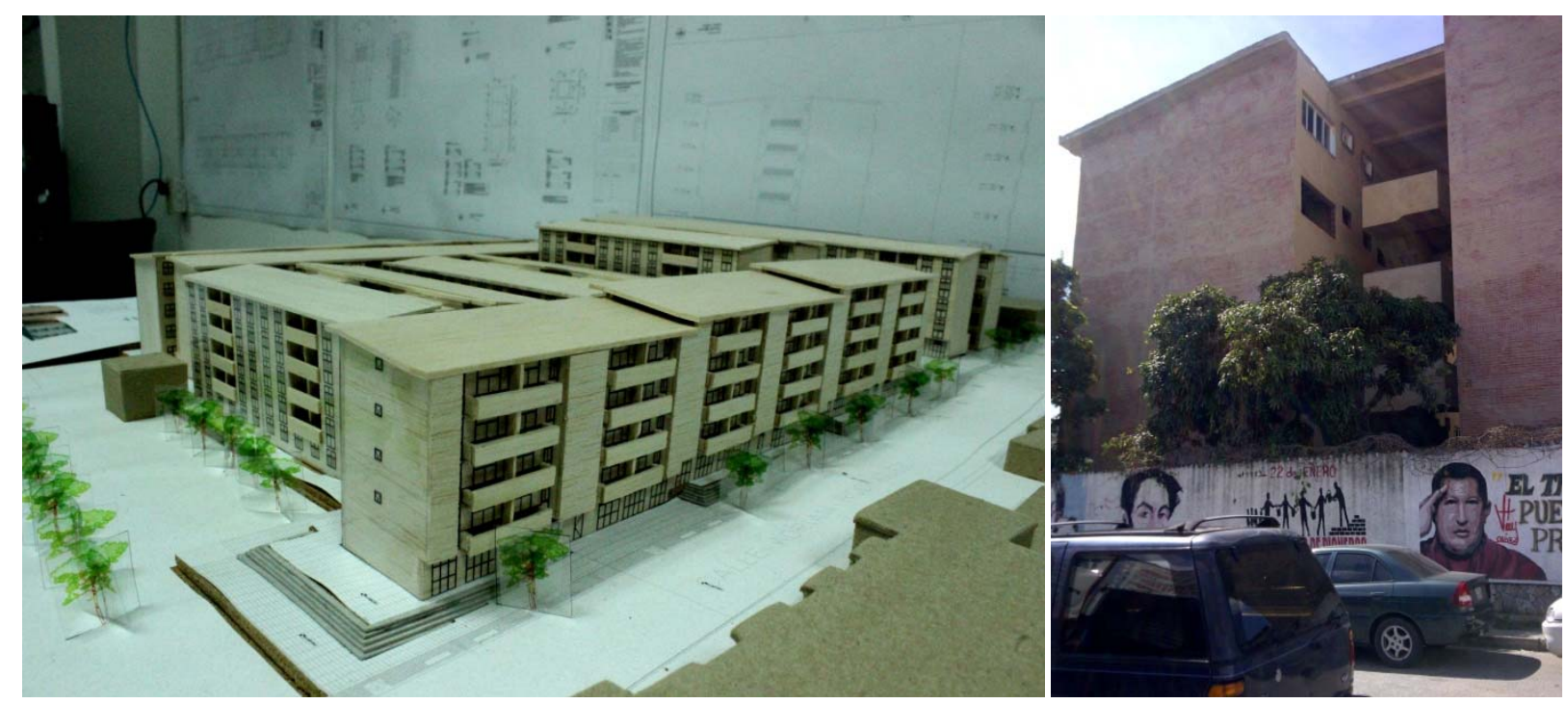

Fig. 100 e 101: Maquete Nueva Comunidade Socialista 22 de Enero e obra em em dezembro de 2014

\section{Nueva Comunidad Socialista Pioneros de Monterrey}

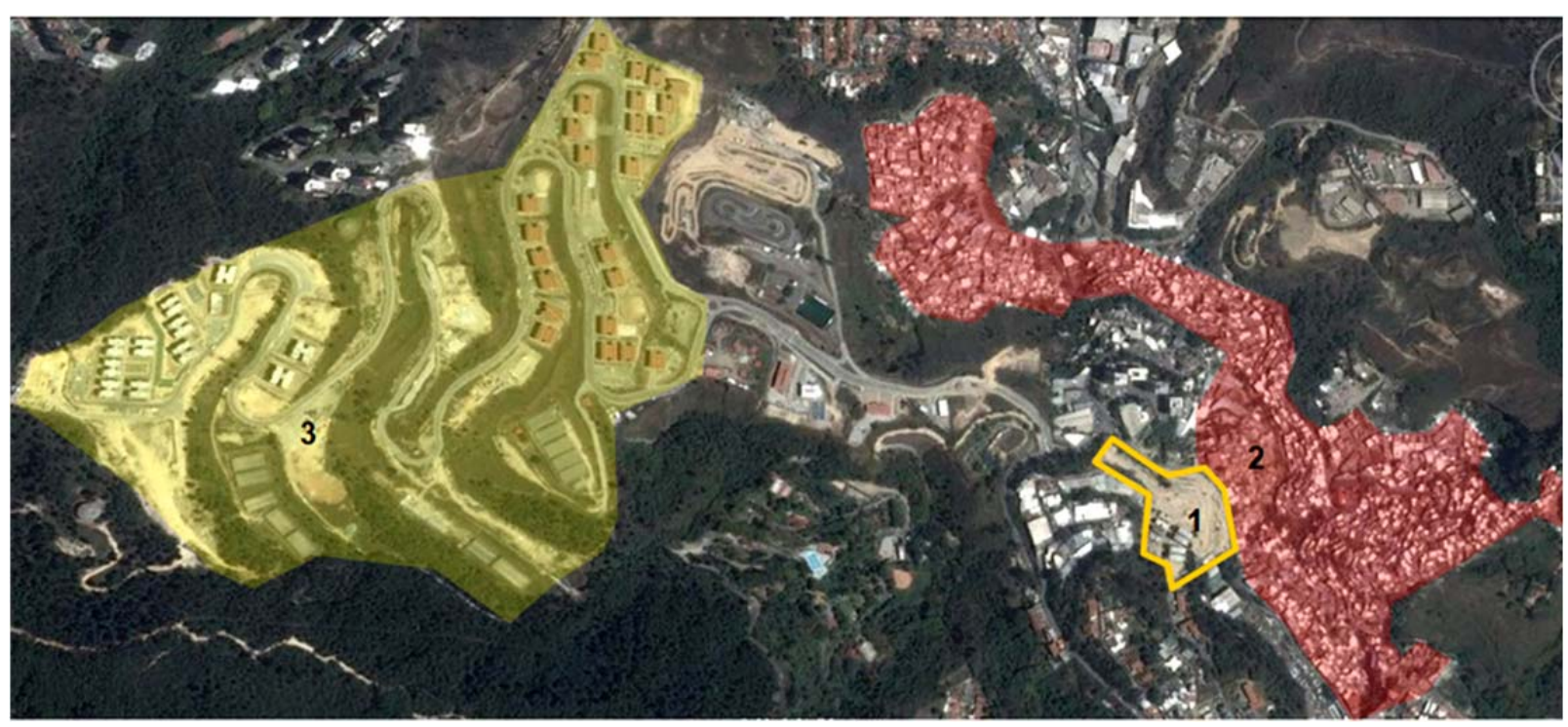

1. Nueva Comunidad Socialista Pioneros de Monterrey; 2. Favela; 3. Gran Misión Vivienda Venezuela.
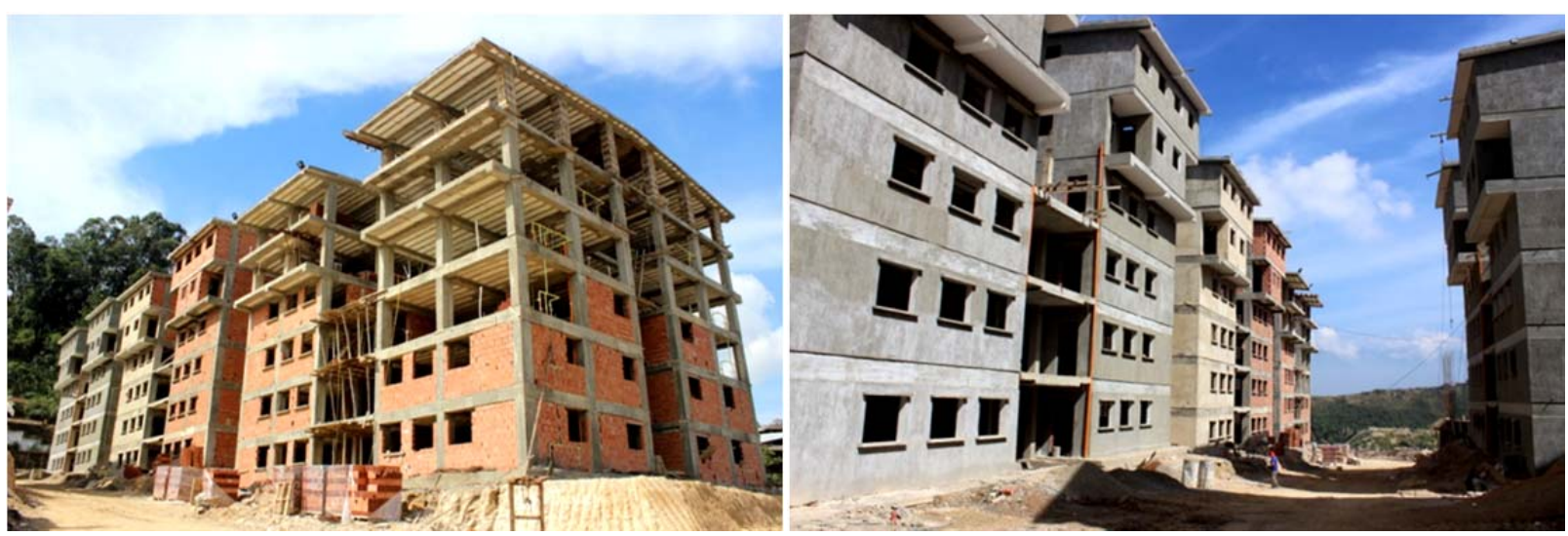

Fig. 102 e 103: Nueva Comunidad Socialista Pioneros de Monterrey 


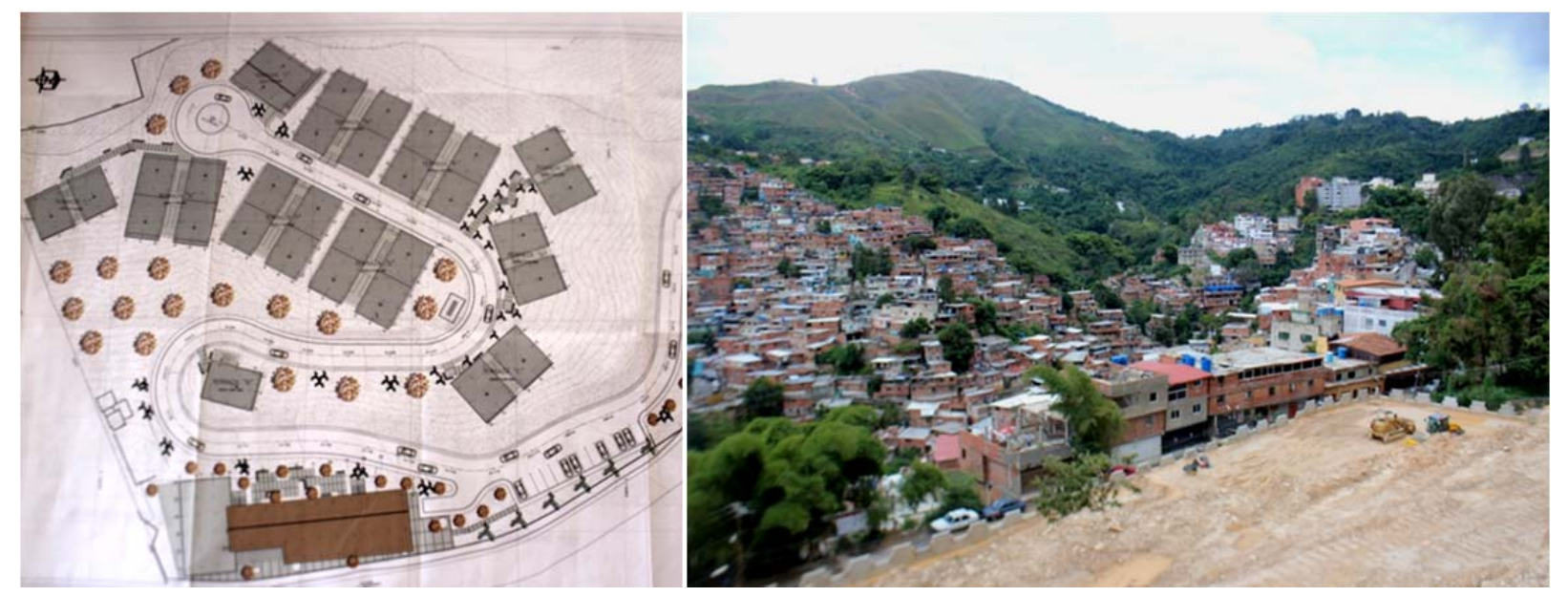

Fig. 103 e 104: Implantação da Nueva Comunidad Socialista Pioneros de Monterrey; Terraplanagem e favela em frente.

\section{Nueva Comunidad Socialista Mi Nueva Venezuela}

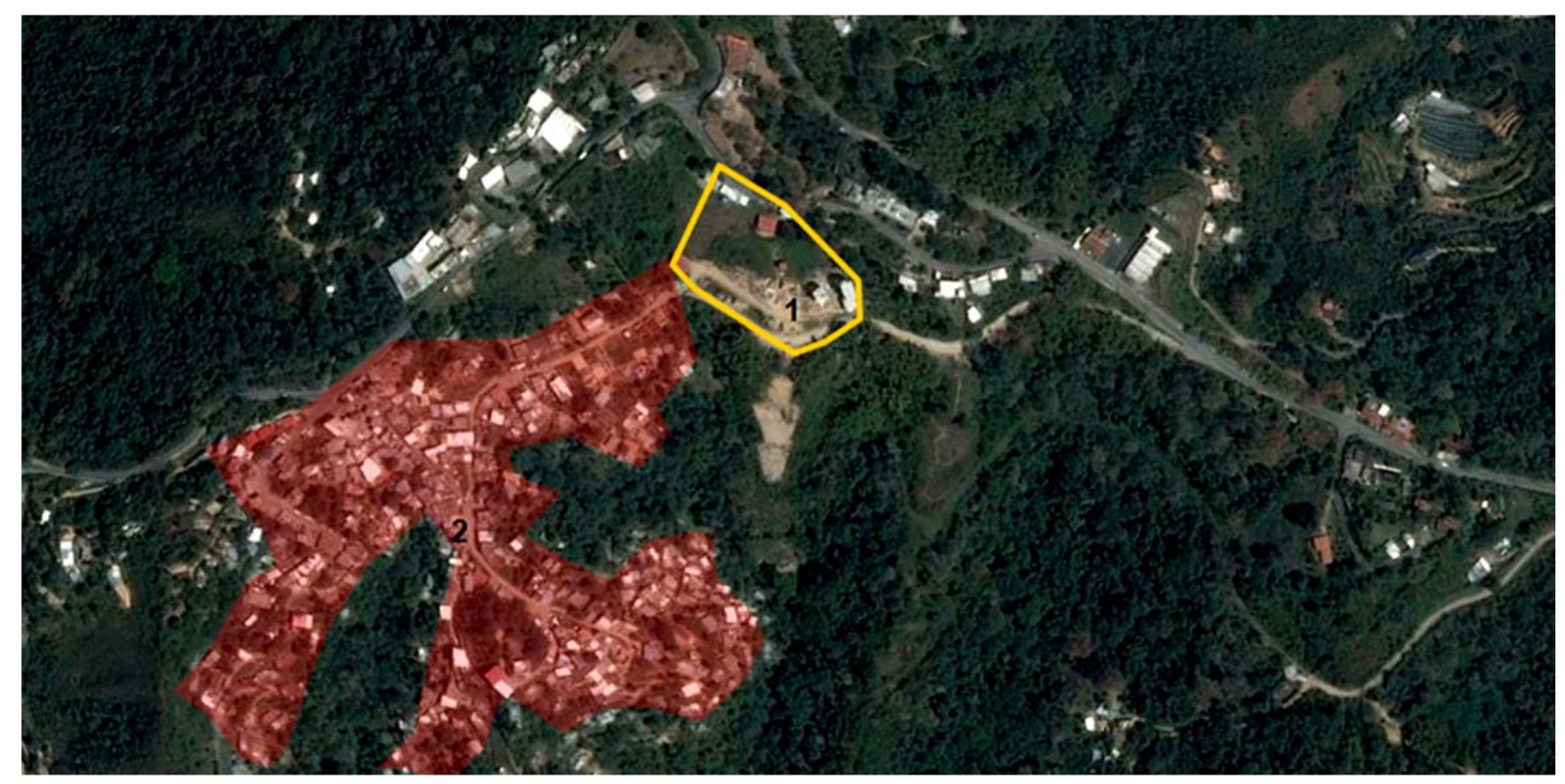

1. Nueva Comunidad Socialista Mi Nueva Venezuela. 2. Favela. 

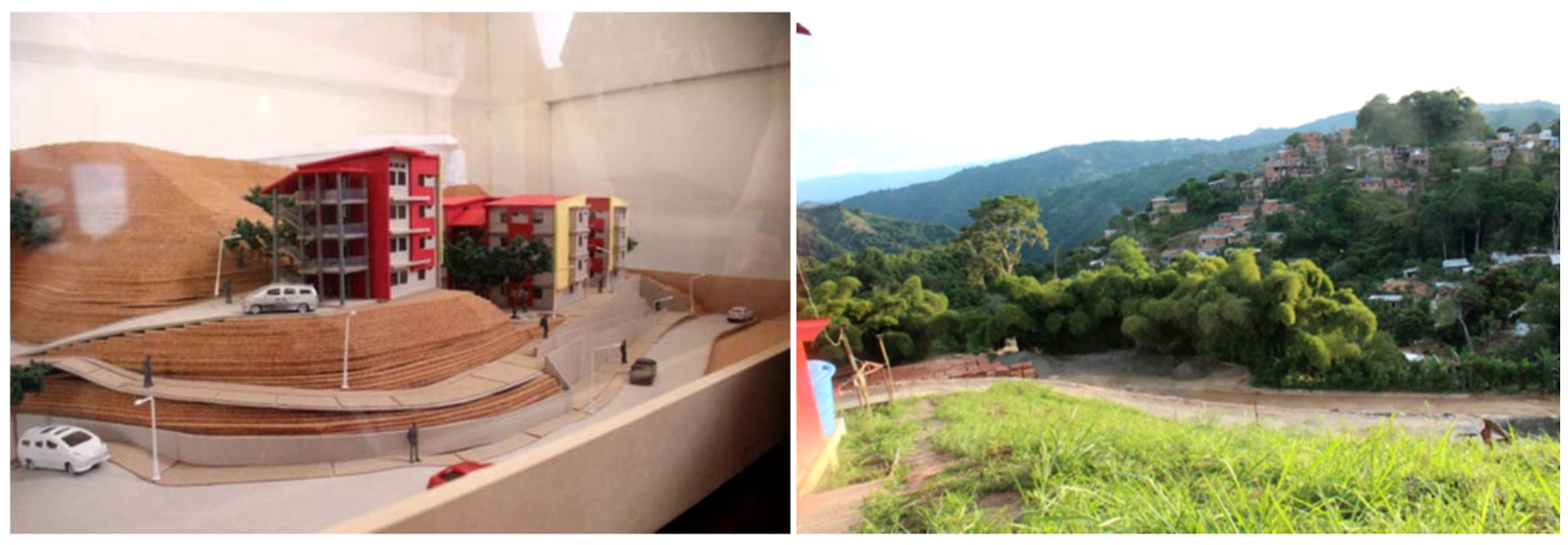

Fig. 105 e 106: Maquete da Nueva Comunidad Socialista Mi Nueva Venezuela; 2. Terreno e Favela em frente.

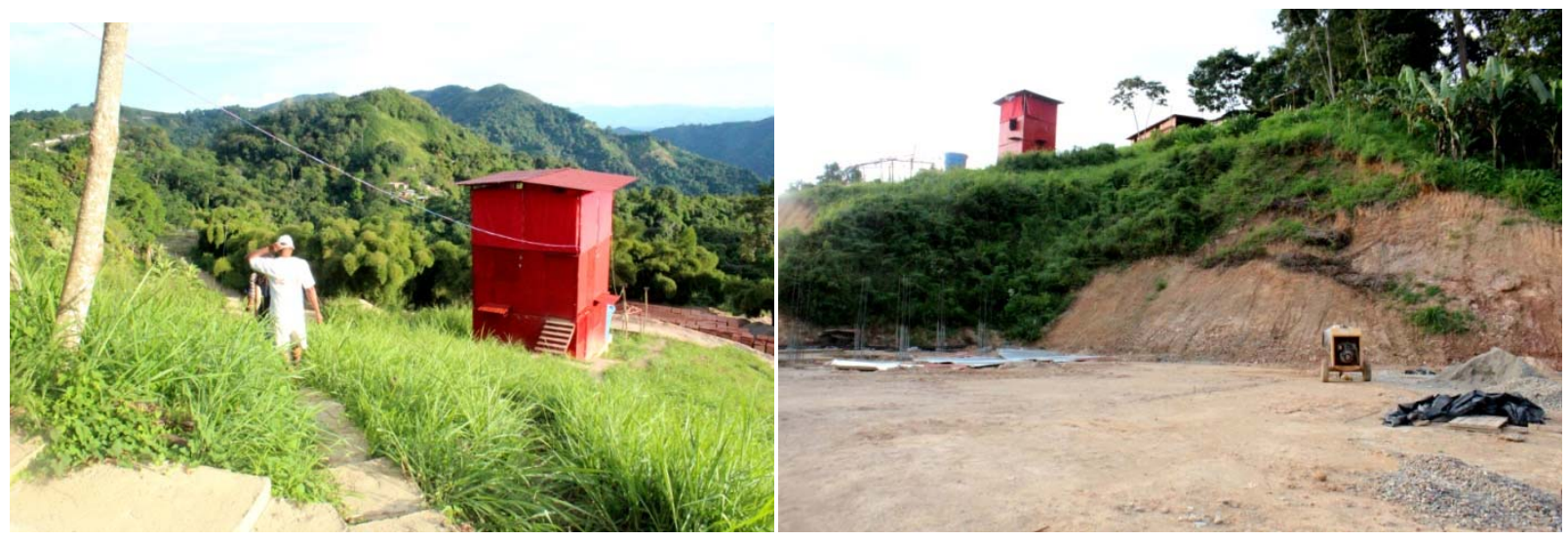

Fig. 107 e 108: Terreno da Nueva Comunidad Socialista Mi Nueva Venezuela.

\section{Outras Comunidades}

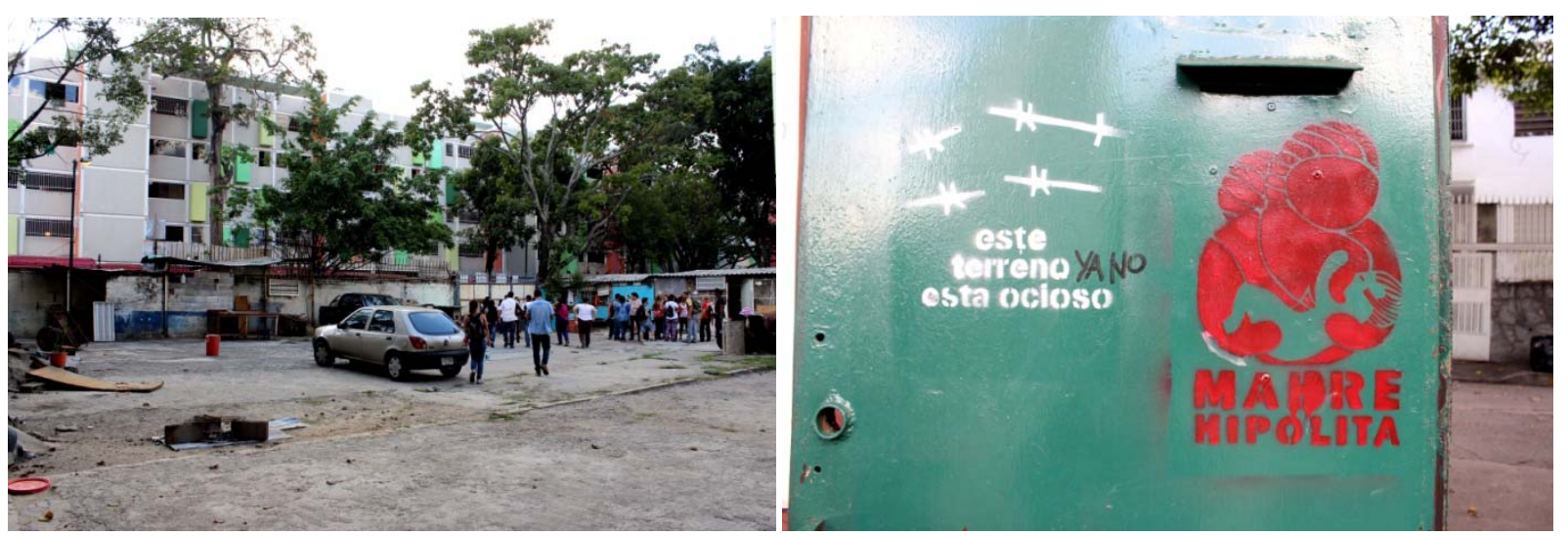

Fig. 109 e 110: Terreno e Portão de Entrada da Nueva Comunidad Socialista Madre Hipólita: Este terreno (ya no) esta ocioso. 


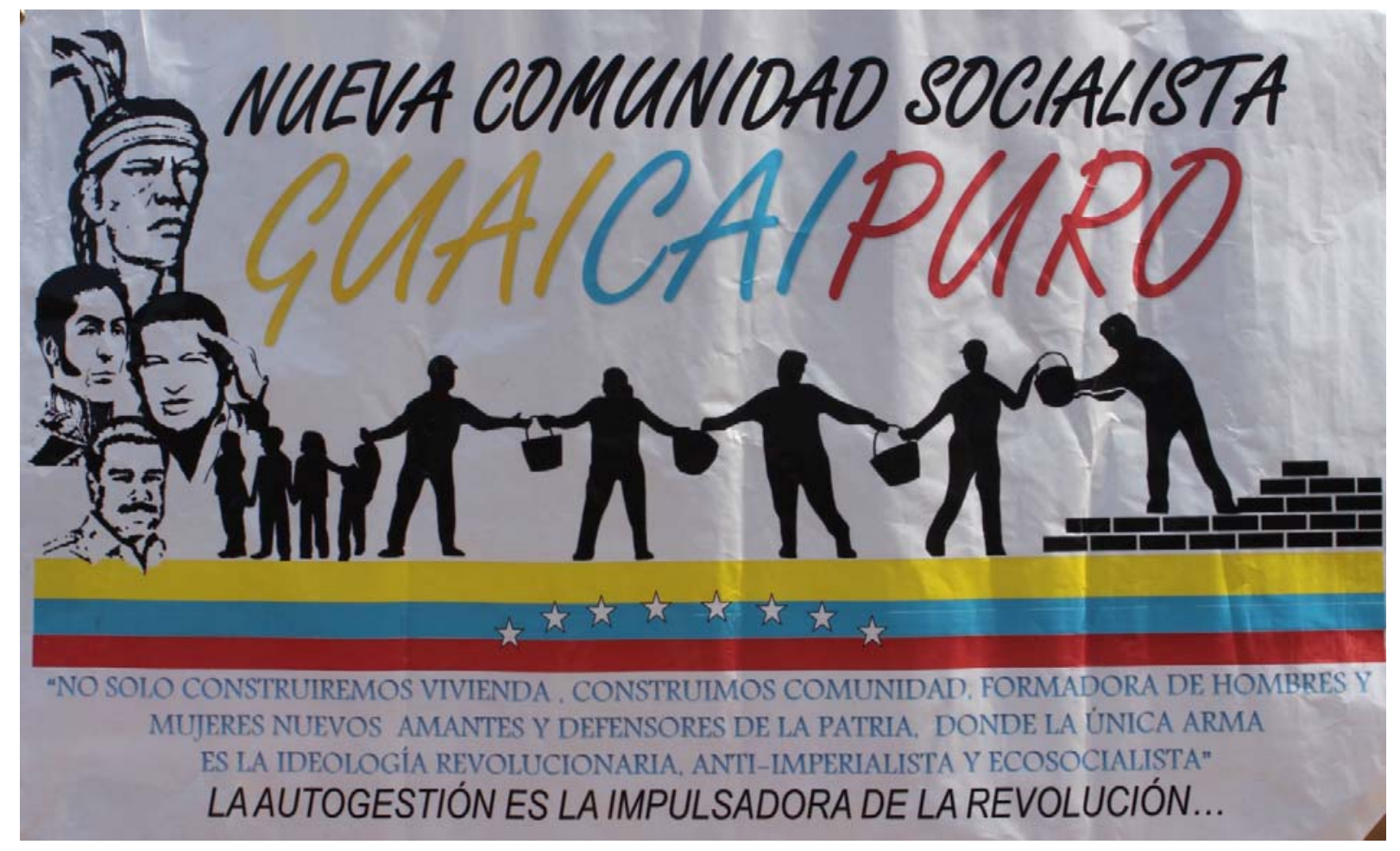

Fig. 111: Cartaz da Nueva Comunidad Socialista Guaicapuro

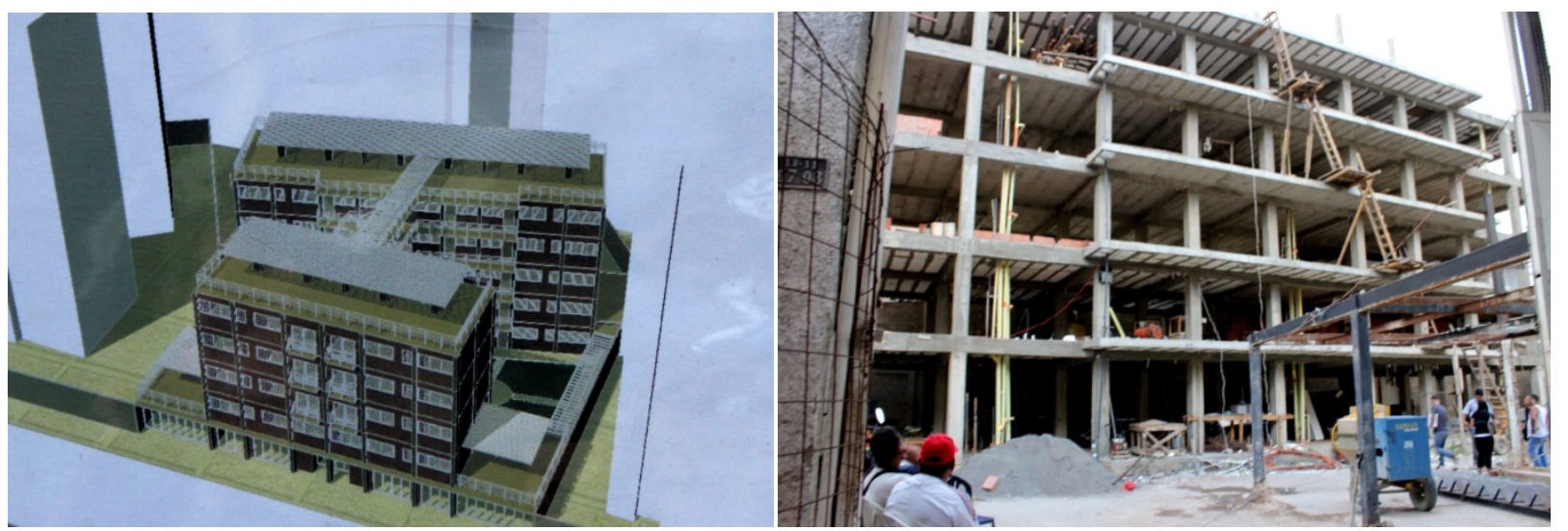

Fig. 112 e 113: Maquete eletrênica e obra em dezembro de 2014 da Nueva Comunidad Socialista Jóvenes en Revolución. 


\section{Uma história: La Vega e Kaika-Shi}

"los hombres se dedicaban a la area de albañeria, contruyendo casas... para otras personas, en edificios, construyendo para otros. ahora construyemos para nosotros mismos no sé si ha escuchado la canción de Cheo Feliciano, Juan Albañil muy interesante:

después que construyen el edificio para la gente de diñero pasa con su niño por frente al edificio y el hijo que lo vio construir este edificio le pregunta: papa porque no puedo entrar y el padre le contesta bueno, porque ya... lo construí pero no tengo derecho a entrar".

Carmen Victoria Comités de Tierras Urbanas e Campamento de Pioneros. 


\section{Juan Albañil - Cheo Feliciano}

(Bueno, familia, ésto es una historia verdadera, y viene sucediendo hace rato, y el hombre ahí.)

Juan Albañil, el edificio que levantaste, con lo mucho que trabajaste, está cerrado, está sellado, es prohibido para tí, Juan Albañil.

Como es domingo, Juan Albañil por la avenida va de paseo mirando cuanto construyó, hoteles, condominios, cuanto lujo,

y ahora como no es socio, no puede entrar. Juan Albañil no puede entrar, no puede entrar.

Juan Albañil, hombre vecino.

Cuanto ha soñado con la llamada igualdad, Juan Albañil. Pero dile a tus hijos que en el cemento no hay porvenir.

Como es domingo, Juan Albañil por la avenida pasa llorando, mirando cuanto construyó, va lamentando la importancia insignificante que el que trabaja tiene después que trabajó, el que trabaja tiene después que trabajó. Juan Albañil no puede entrar.

En los andamios, sueña que sueña,

Juan Albañil, con el día de la igualdad.

Pero cuantos condominios ese hombre va construyendo, y mañana es la misma puerta, de ahí mismo lo van huyendo, que sí, que sí.

Y en los andamios de la vida, con palustres de hermandad, fabricaremos algún día la casa de la igualdad, y digo yo.

$Y$ en esa casa, señoras y señores,

no habrá distinción jamás, gente de toditos los colores, con Juan Albañil, toditos podrán entrar.

(Recoge esa pala, tira mezcla, pásame ese balde

rómpete la espalda, Boricua, que ésto es así.)

Como es domingo, Juan Albañil pasea por todita la ciudad, y sus nenés le preguntan, Papi a ese edificio tan grande, ¿por qué yo no puedo entrar?

La rumba, la rumba y la rumba de la existencia, la baila la humanidad, aunque le pese la conciencia, como Juan Albañil, ésta es la desigualdad.

Bendito! Obrero, valiente Juan Albañil, oye, hombre, que le mete frente al destino. Ése es, ése es, ése es.

De siete a cuatro muchachos, media hora, a almorzar, metiendo molledo y brazo,

las manos bien repletas de callo ya, mas...

Juan Albañil, hoy te digo que ese día ya vendrá,

El tiempo será testigo, lo tuyo será tuyo, mira, y de nadie más.

(Definitivamente, Juan Albañil,

Por lo menos para mí, tú eres un señor.) 
Aqui en esta experiencia, humildemente, en Kaika-Shi, aqui en la parroquia La Vega, tenemos algo autogestionário, una experiencia diferente. Por primera vez, Juan Albañil, va vivir en lo que construye, y no porque se está dando nadie, sino de una manera autogestionária.

Edgar Pérez

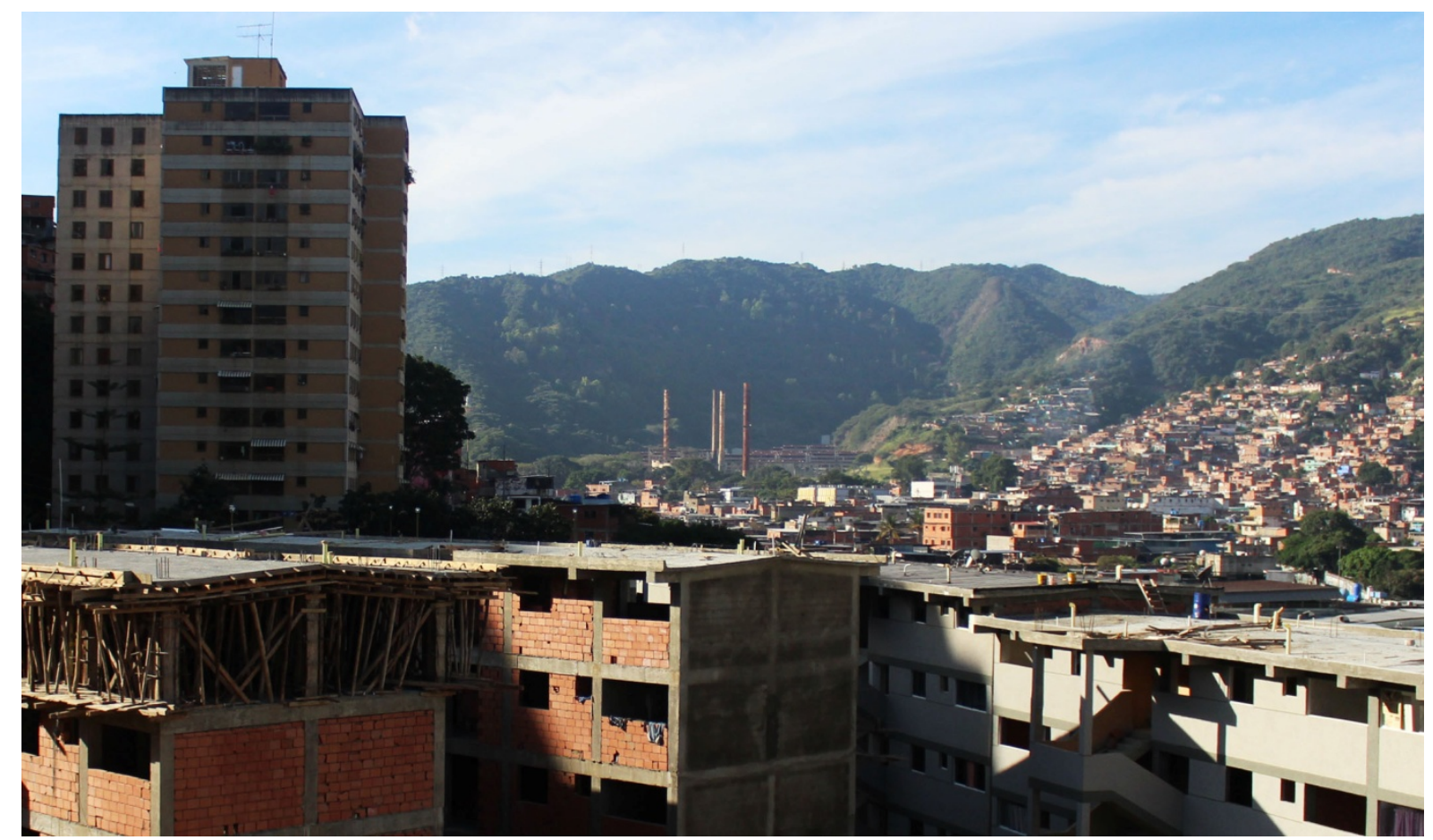

Fig 114: La Vega

Atrás dos edifícios em construção de Kaika-Shi, a favela de La Vega domina a paisagem. Incrustrada na favela, as torres em ruína da primeira fábrica de cimento da Venezuela. Vizinho a Kaika-Shi, edifícios verticais construídos pelo Estado para receber desabrigados pelas chuvas, mas que acabaram ocupados por famílias de classe média. A paisagem de La Vega lembra a forma como Milton Santos define o espaço: a "acumulação desigual de tempos".

A instalação da fábrica de cimento em 1907 serviu como pólo de atração para outras indústrias, incorporando a população migrante à produção industrial. Em 1920 se instalou um fábrica de curtinas, e em 1938 uma fábrica de confecç̧ão. Os ativos da fábrica foram arrendados a Carlos Delfino, que se casou com Josefa Gómez, filha do General Juan Vicente Gómez. Entre os laços familiares, os laços dos donos de terrenos, do poder, e dos meios de produção da cidade.

A expansão da urbanização ocorreu em paralelo ao desenvolvimento da especulação imobiliária. Nas palavras do próprio urbanista francês Maurice Rotival, 
"Para mi Venezuela estaba dirigida en mi época enteramente por una élite que se casaba entre ella, todos tenían lazos matrimoniales y había una fosa profunda entre la élite y la clase llamada burguesa, no existía ningun contacto. Tampoco con la clase obrera. La burguesía estaba formada en general por empleados (...) pero las grandes decisiones las tomaba la élite dirigente. Ellos iban a ver al Presidente sin ningún problema, entraban como en su propia casa. Era ellos los que mandaban.

Venezuela estaba dirigida por un grupo de aristócratas ricos propietarios de la tierra. Familias ricas que eran en general alemanas e inglesas. Todo lo que estaba hecho en Venezuela antes de mi llegada fue hecho por los ingleses, fueron ellos quienes hicieron el tren. (...). La fortuba de los Vollmer era enorme, no tenía nada que ver con el petróleo. Habia que ver las haciendas formidables que poseían.

El Paraíso era el sector residencial más elegante, allí vivían todas las personas importantes y a continuación se encontraba la hacienda La Vega que pertenecia a Reinaldo Herrera, cuyo hermano estaba a la cabeza del Banco Caracas. Reinaldo Herrera, vivía en la hacienda con su familia y su suegro, era mi amigo y yo dormía allí algunas veces, él administraba la hacienda. Ellos comprendieron que se podía ganar más dinero en el proceso de venta y especulación de terrenos. Dejaron de oponerse al Plan".

La Vega apresenta uma história parecida com o 23 de Enero, com um crescimento explosivo a partir da queda de Pérez Jimenez. Nas palavras de Jean Pierre Wyssenbach ${ }^{54}$,

"El barrio Carmen habia una pequeña capilla que había sido hecha por los pobladores a partir del año 1958, que es cuando La Vega crece de una forma explosiva. Han tumbado a Marco Pérez Jimenez y se van formando los diversos barrios y se va invadiendo a la parte del barrio El Carmen. Allá en esa capilla en el sótano vive Francisco Wytack"

Jean Pierre se referia ao padre belga que se instalou em La Vega, e se tornou a principal referência para a organização política daquela comunidade ${ }^{55}$. Nas palavras do líder comuntário Edgar Pérez, "este cura llega de una manera muy utopica, en ese sentido llega a la comunidad tratando de prestar ayuda, con este mandato cristiano, con la practica el hombre va concientizandose de las demandas sociales".

\footnotetext{
${ }^{54}$ Documentário La Vega Resiste.

55 "Francisco Wytack es belga. Es de una familia trabajadora. El abuelo de el, se llamaba Franz Wytack y fue el primero que organizó una huelga en los muelles de Ambere. Nosotros en Venezuela tendemos que entender que para Belgica los muelles son como el petróleo para Venezuela, es la mayor fuente de ingreso. En ese sentido se trata de un personage historico, el primero que defendió de forma organizada los intereses de los trabajadores. En ese ambiente crece Francisco Wytack". (Jean Pierre Wyssenbach)
} 


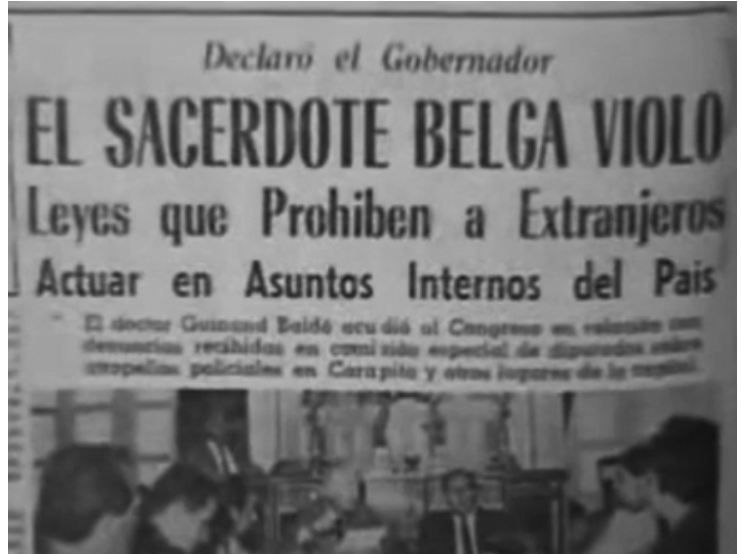

Fig. 115.

Fonte: Documentário La Vega Resiste
Francisco Wytack liderou uma manifestação em direção ao Congresso Nacional, onde se acorrentou às grades do edifício. A partir de então, sofreu a repressão do Estado venezuelano, tendo negado o visto de permanência. São diversos os testemunhos da influência de padres vinculados à teologia da libertação nas favelas de Caracas.

Antes da explosão urbana pós 1958, um dos fatores que levaram à urbanização de La Vega foi a instalação da fábrica de cimentos La Vega no ano de 1907. Segundo o documentário La Vega Resiste,

"Desde allí, cementos La Vega constribuye al crecimiento urbano del país por más de siete décadas, siendo a la vez factor contaminante del ambiente en un radio de hasta 500 mil personas. Su salida por presiones ocurre al principio de los años 80. La Vega, que a mediados del siglo XX era el casco central de los pequeños barrios de la ladera de San Miguel, comienza una explotación desbordante con la construcción de grandes bloques multifamiliares en los años 50 bajo la dictadura de Marco Pérez Jimenez. Desde ese momento se inicia en La Vega un período de más de 40 años de lucha constante por la tierra, la educación, la libertad, y el derecho a una vida digna".

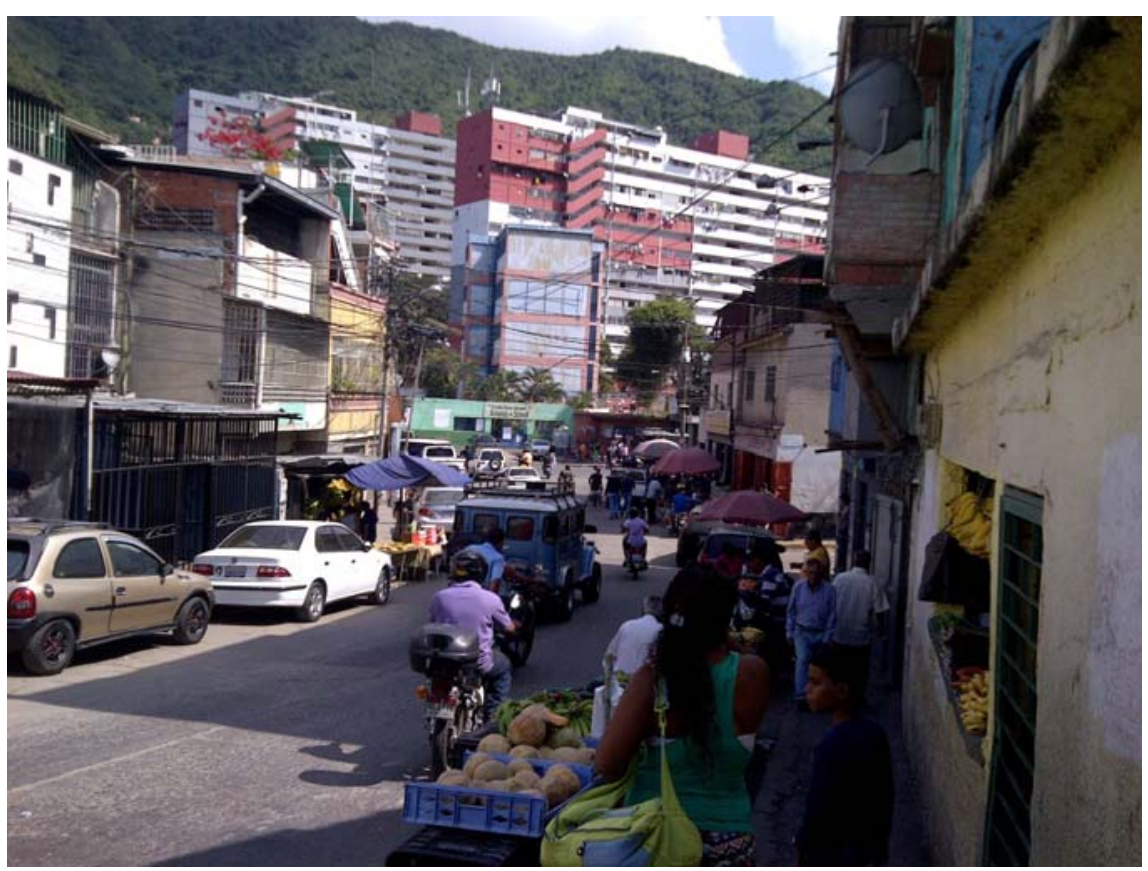

Fig 116: La Vega e os Superblocos. 


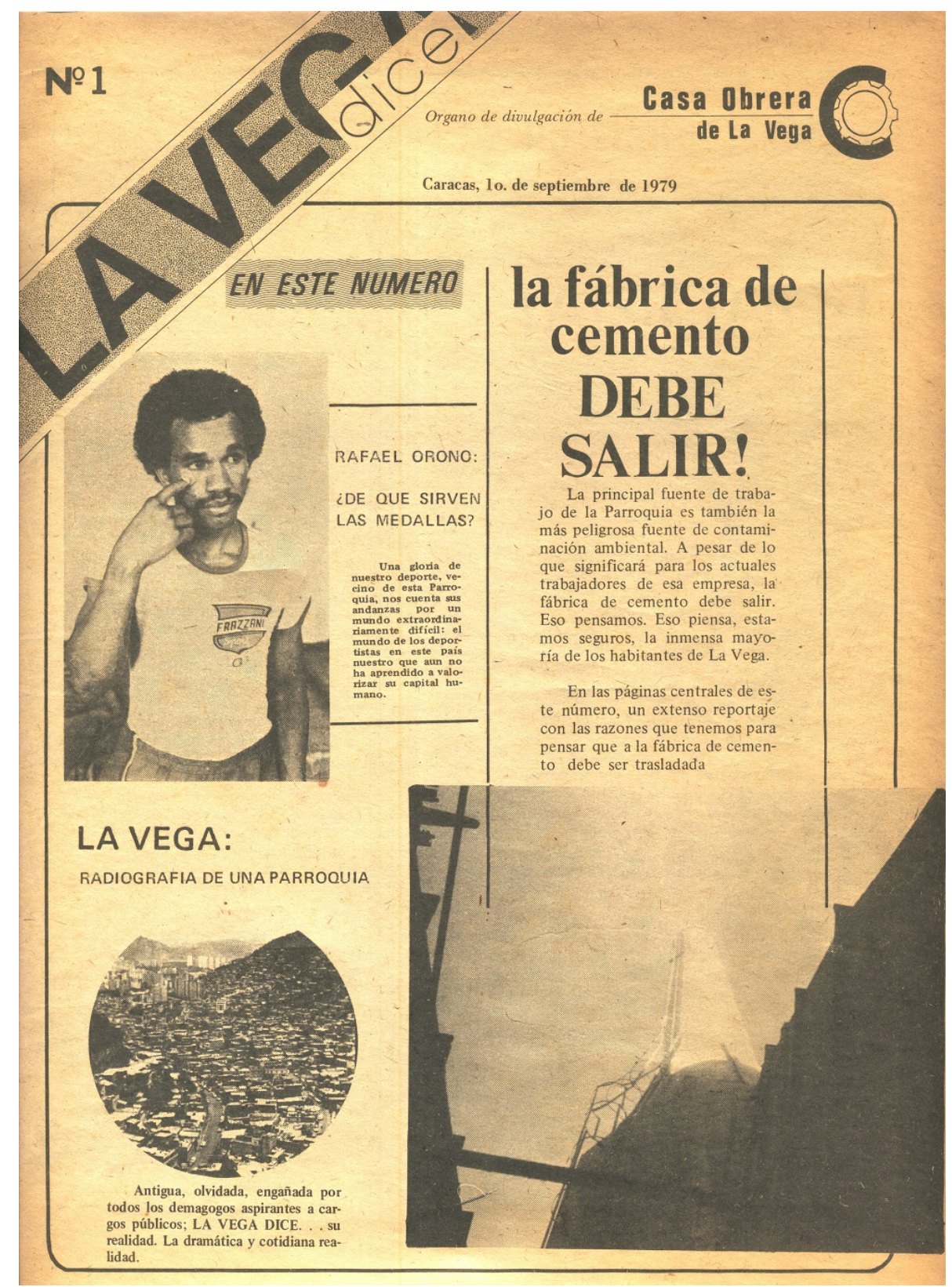

Fig 117: Periódico La Vega Dice.

Um importante instrumento de luta da população de La Vega contra a fábrica de cimento foi o periódico La Vega Dice, publicado pela Casa Obrera de La Vega. A luta contra a fábrica foi a primeira grande pauta deste jornal que existe até hoje. Segundo Edgar García,

"Eso generó que a través de nuestras páginas se diera un debate local, incluso nacional. Hubo una lucha que terminó con una decisión del Tribunal Supremo de Justicia en donde este decreta la salida de la fábrica de cemento, ya que en la parroquia La Vega y en gran parte del suroeste, el 70\% de la población tenía enfermedades pulmonares. Este 
es uno de los primeros triunfos de La Vega y donde el periódico fue un bastión de lucha" 56.

Segundo Estílita Ruiz, a publicação contava com a colaboração de estudantes da Universidad Central de Venezuela, que apoiavam de forma clandestina em razão da perseguição da $\operatorname{DISIP}^{57}$ que considerava o boletim material subsversivo. A fábrica de cimento La Vega foi então re-instalada no Valles del Tuy Medio, região de recente expansão periférica da Grande Caracas. Parte das instalações da fábrica permanecem no local, enquanto a maior parte do terreno foi utilizado para a construção do conjunto Terrazas de La Vega, com 67 blocos e um total de 1.970 unidades habitacionais. Esses edifícios estão apenas parcialmente ocupados, em razão dos problemas estruturais que apareceram durante as chuvas de 2010.

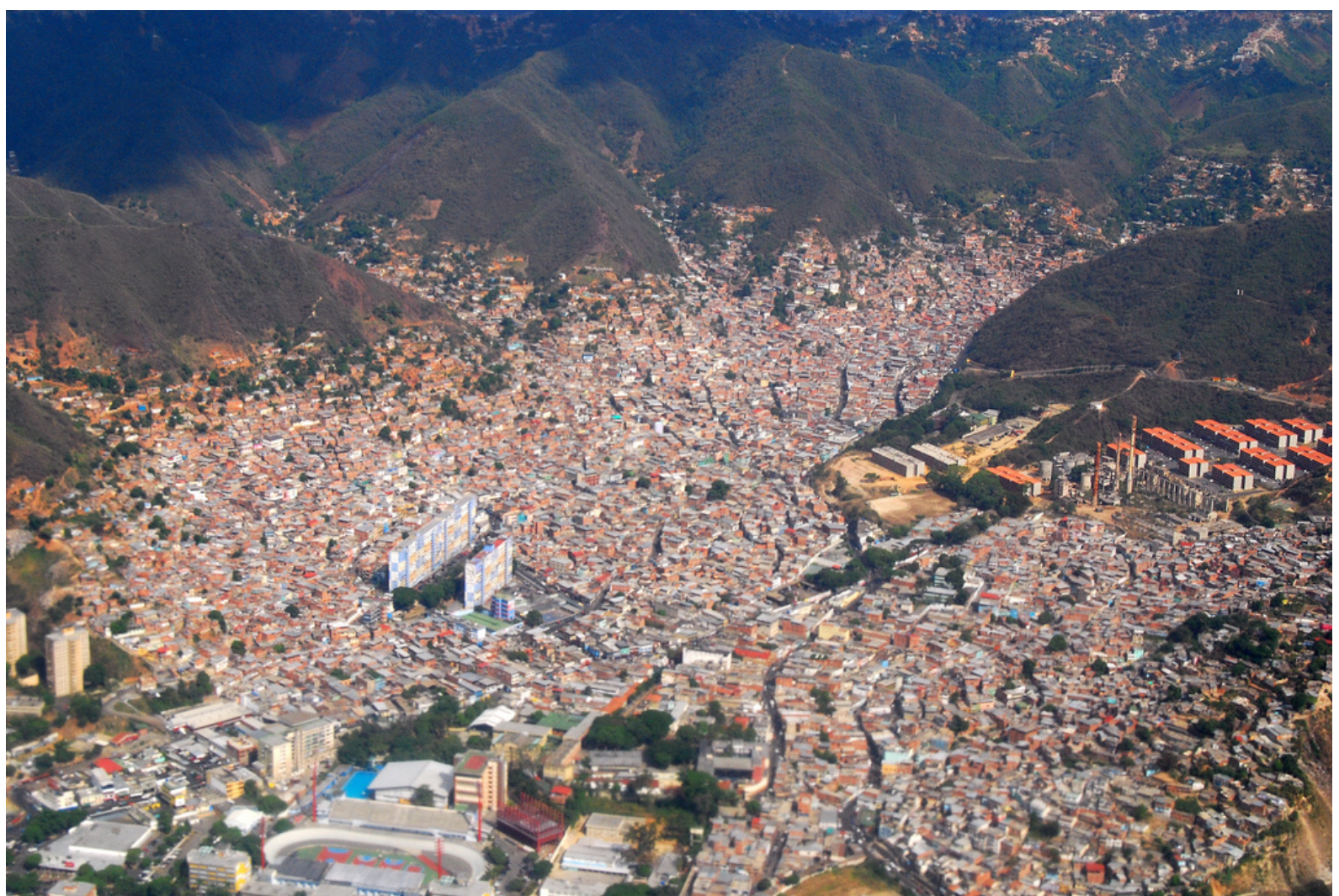

Fig. 118: La Vega: Superblocos modernos envolvidos pela favela. À direita, as ruínas da fábrica de cimento e o empreendimento Terrazas de La Vega.

Além da teologia da libertação e do movimento estudantil, Edgar Pérez lembra da influência do movimento guerrilheiro da década de 1960, influenciado pela Revolução Cubana: "los guerilleros urbanos de ese momento, de la guerrilla de los 60, tuvieran incidencia dentro del barrio, en la

\footnotetext{
56 "La Vega Dice: 30 aniversario del diario alternativo", em http://sicsemanal.wordpress.com. (acessado em dezembro de 2014).

57 Antigo órgão de inteligência (Dirección Nacional de los Servicios de Inteligencia y Prevención), atual SEBIN (Servicio Bolivariano de Inteligencia Nacional).
} 
formación ideológica de la gente del barrio, en la formación ideológica de los jóvenes de la parroquia" ${ }^{58}$.

Todos os grupos políticos que se envolveram com La Vega concentravam os esforços nas demandas objetivas colocadas pela ocupação: "La fundación del barrio, la defensa de los terrenos ante las fuerzas de seguridad y los primeros esfuerzos colectivos por mejorar la miserable situación del principio, fortalecen la cohesión interna de los pobladores” (Calzadilla, et.al., 2000). Segundo uma das lideranças comunitárias, Mariela Machado, diversas partes do bairro ficaram até 17 anos sem receber água.

Para Calzadilla et. al. (2000), "los logros conseguidos por la comunidad de Las Casitas de La Vega son resultado de estrategias que se han desplegado a lo largo de su historia: el diálogo, la autodefensa, la protesta, el autogobierno, las acciones de la gente para mejorar su nivel de vida ante las infructuosas políticas del Estado".

Mariela Machado, Edgar Pérez, e Andrés Antillano, assim como outras lideranças históricas de La Vega, foram protagonistas diretos na luta pela água e pelo reconhecimento da favela pelo Estado, e atualmente fazem parte ou são muito próximos ao Movimiento de Pobladoras y Pobladores. Mariela Machado, militante dos Comités de Tierras Urbanas de La Vega, está à frente da construção da Nueva Comunidad Socialista Kaika-Shi, edifícios construídos por autogestão com financiamento estatal, e que tem se tornado uma das principais referências organizativas da região.

A participação de Andres Antillano, militante dos CTUs desde o início do processo tendo feito parte da comissão redatora do histórico Decreto 1666, narra da seguinte forma a luta de La Vega nas décadas de 1980 e 1990 :

"Cuando llego a La Vega a fines de los 80, mi militancia tiene lugar en espacios de esa naturaleza: grupos eclesiales, periódicos populares, teatro, trabajo con niños, alfabetización, etc. Pero pronto las cosas empezaron a cambiar. Se producen violentas protestas como resultado de un derrumbe que tapió a numerosas familias en un barrio de la parroquia (el sector llamado Las Madres), se hacen cada vez más frecuentes e intensas las luchas por la falta de agua, se producen movilizaciones contra el aumento del pasaje, o por el estado de las calles, contra los intentos de construir primero una cárcel y luego un cementerio en las áreas verdes que rodean la parroquia, o por la seguridad jurí- dica y contra la amenaza de desalojos 6 . Me parece que buena parte de aquellos que militaron en las luchas barriales entre los 80 y los 90 cuentan con un itinerario semejante."

Héctor Gutierrez, em entrevista a Enrique Torres (2001), relata a articulação da luta de La Vega com as Asambleas de Barrios de Caracas, e formação dos comitês setoriais (que seriam, afinal, a idéia geradora dos CTUs).

\footnotetext{
${ }^{58}$ Documentário La Vega Resiste.
} 
"Lo más interesante fue hacer las reuniones en los mismos barrios. Por ejemplo, en aquel entonces Andrés Antillano vivía en La Vega, cerca de un lugar que no sé si todavía existe que era cementos La Vega, y había un pequeño local ahí, y entonces él dice: 'bueno, por qué no hacemos la próxima Asamblea de Barrios ahí donde está La Vega'. Y se hizo la reunión en La Vega. Él [Andrés Antillano] organizó con la gente de La Vega la logística y se hace una reunión allí y se hacen unas minutas donde comienzan a conformarse Comités de Trabajo. [...] Se crea un Comité de Vivienda, un Comité de Salud, un Comité de Comunicación, un Comité de Educación, un Comité de Organización, un Comité de Agua, etc. [...] Luego se hizo una en El Guarataro, luego otra en La Vega en las Casitas, otra en Caricuao, otra en Antímano. [...] Eso le permitió a la gente verificar en el mismo terreno que los problemas eran comunes. Entonces la gente decía somos la misma gente, estamos viviendo procesos similares y tenemos una propuesta de poder auto-organizarnos y buscar por nosotros y nosotras mismas la solución de nuestros problemas” (Hector Gutíerrez em entrevista a Torres, 2011).

O terreno onde está localizada a Nueva Comunidad Socialista Kaika-Shi é próximo ao centro de La Vega. Segundo Mariela Machado, o terreno é resultado de uma luta histórica dos mais velhos, especificamente de "el gordo Edgar Pérez" que em 1974 ocupou o terreno. Naquele ano houve o desalojamento de muitas famílias em razão de chuvas em La Vega, e Edgar liderou uma greve de fome. Com a negociação, conquistaram junto ao Estado, especificamente ao Centro Simón Bolívar, a construção de edifícios naquele terreno. No entanto, uma vez finalizados, foram destinados a pessoas de classe média.

Segundo Mariela, "en un encuentro nacional de los CTU se vió la importancia de recuperar suelo ocioso, como este, pues. Este era del Estado, del Centro Simón Bolívar, subutilizado por una sola família". Nas palavras de Edgar Pérez, "yo vengo con la compañera Mariela y con la gente que estaba trabajando en la via autogestionária y tomamos el terreno".

As principais conquistas dos Campamentos de Pioneros foram consolidadas no dia 8 de janeiro de 2010, em encontro com Hugo Chávez. Segundo Alberto García, de Kaika-Shi, "como llegamos a ese ocho, no? Porque a veces parece que fuera algo autonomatico, no? Fueran casi 7 años de actividad política, de tomas en la calle, nosotros salíamos a la calle a respaldar la decisión junto al Estado y así poco a poco nos visualizamos como movimiento". 


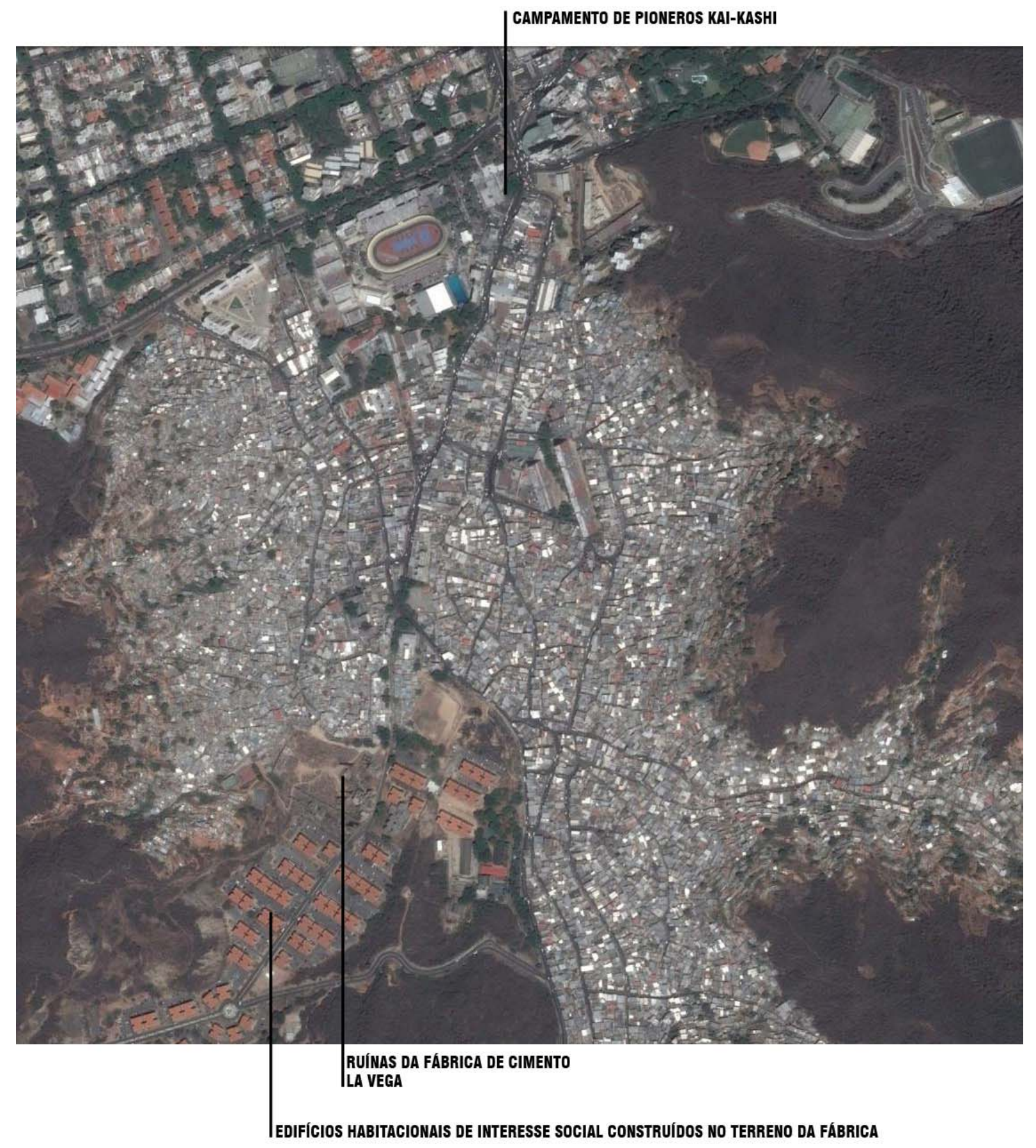




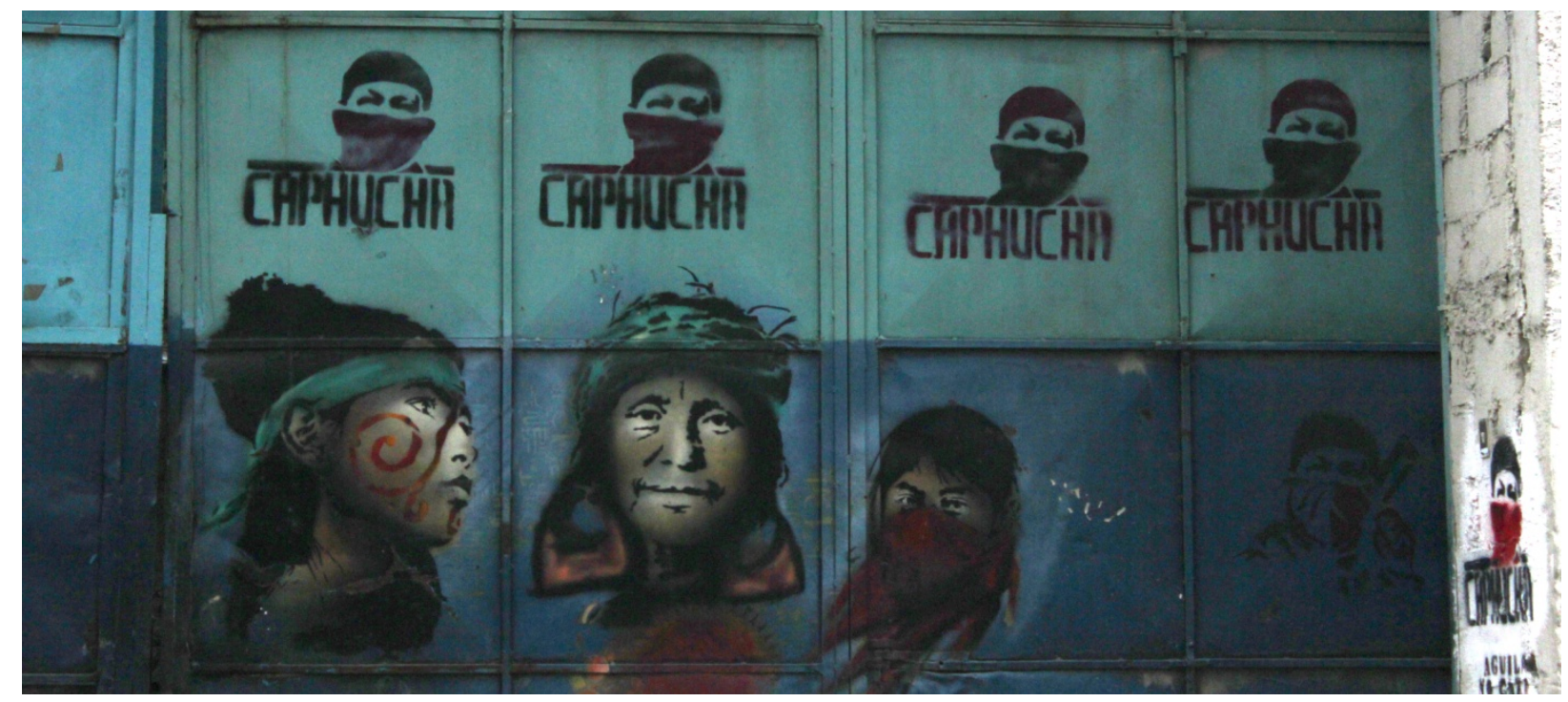

Fig. 119: Portão de Entrada da Nueva Comunidad Socialista Kaika-Shi.

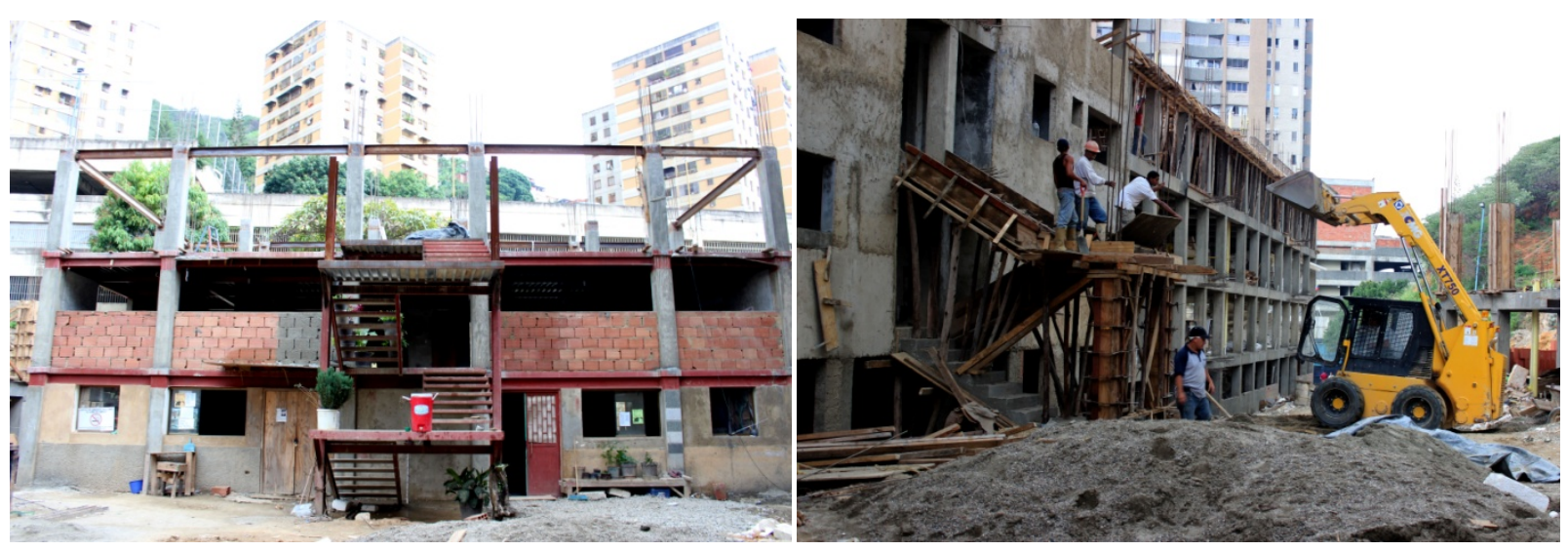

Fig. 120: Construção da cozinha, refeitório, sala técnica e quarto de hóspedes e Construção da NCS.

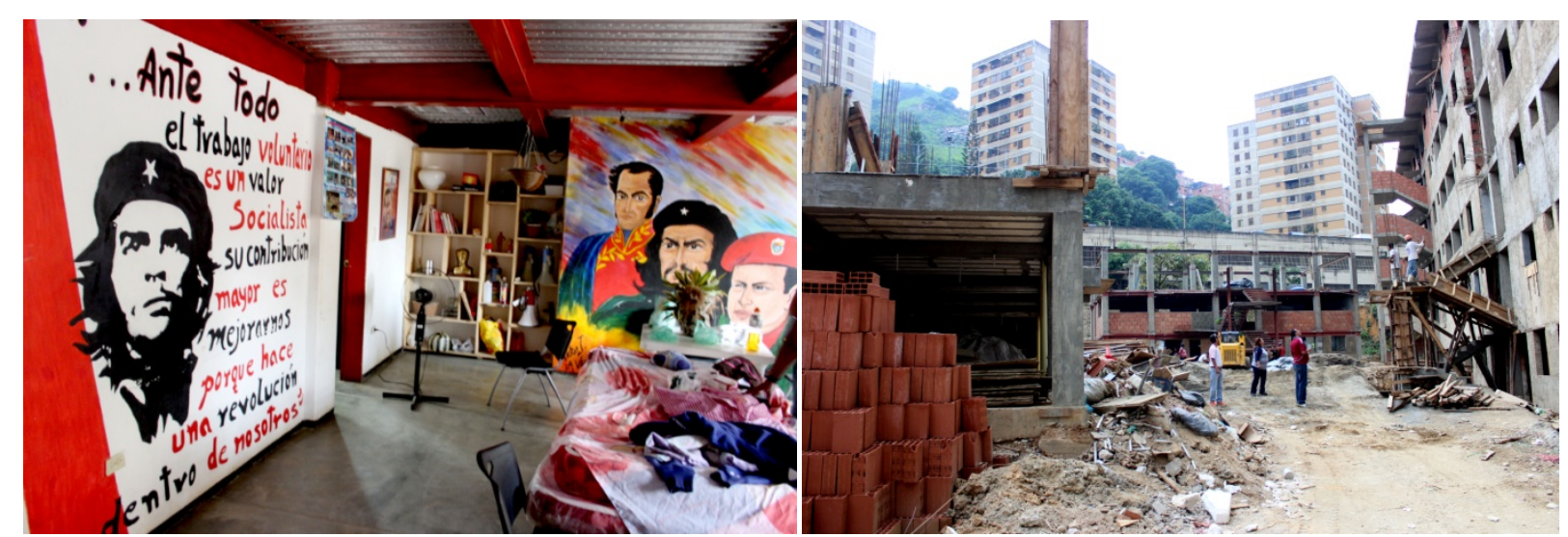

Fig. 121: Sala de Reunião e Construção da NCS. 


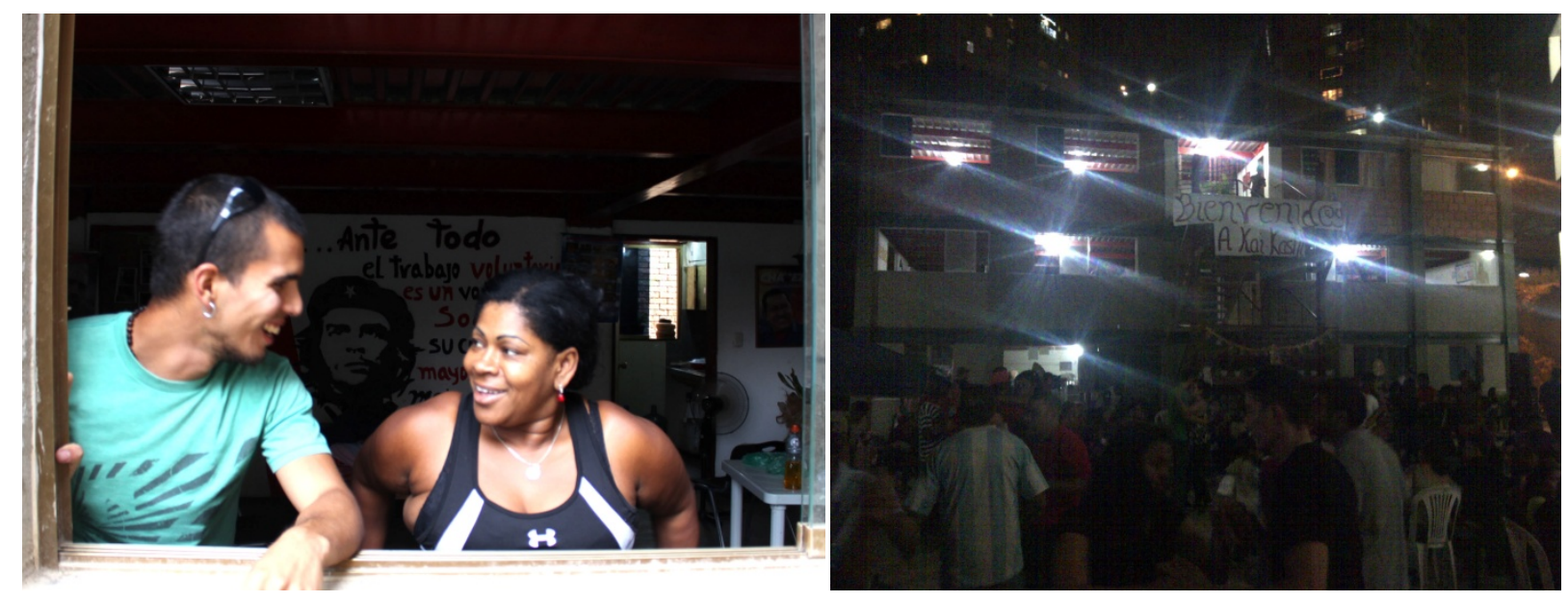

Fig. 122: David Grajales e Mariela Machado e Dia de festa em Kaika-Shi.

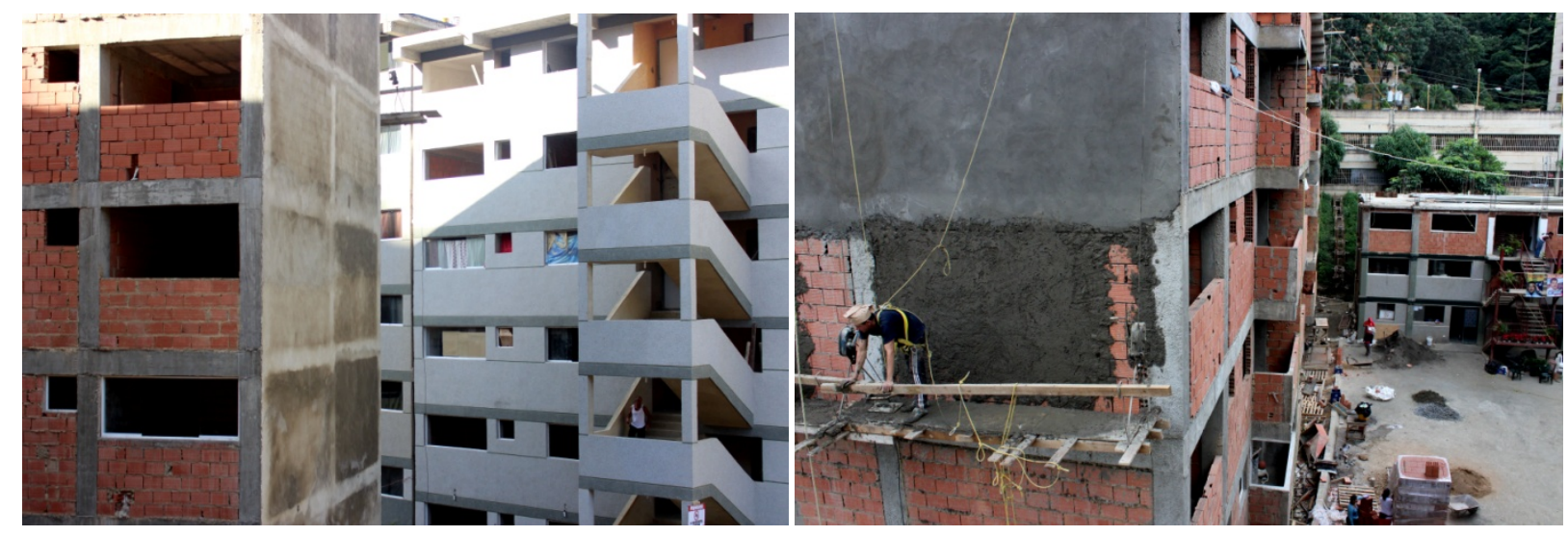

Fig. 123: Bloco em construção e bloco finalizado e Trabalho na fachada.

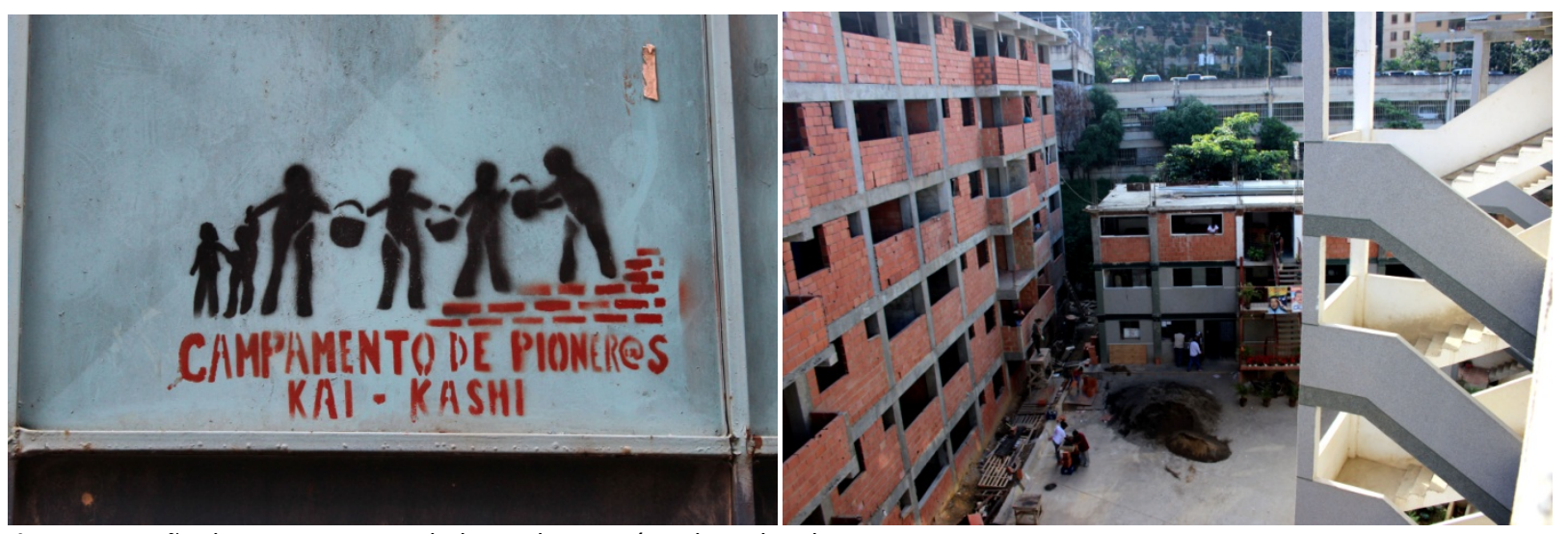

Fig. 125: Portão da Nueva Comunidad Socialista e Pátio de Kaika-Shi. 


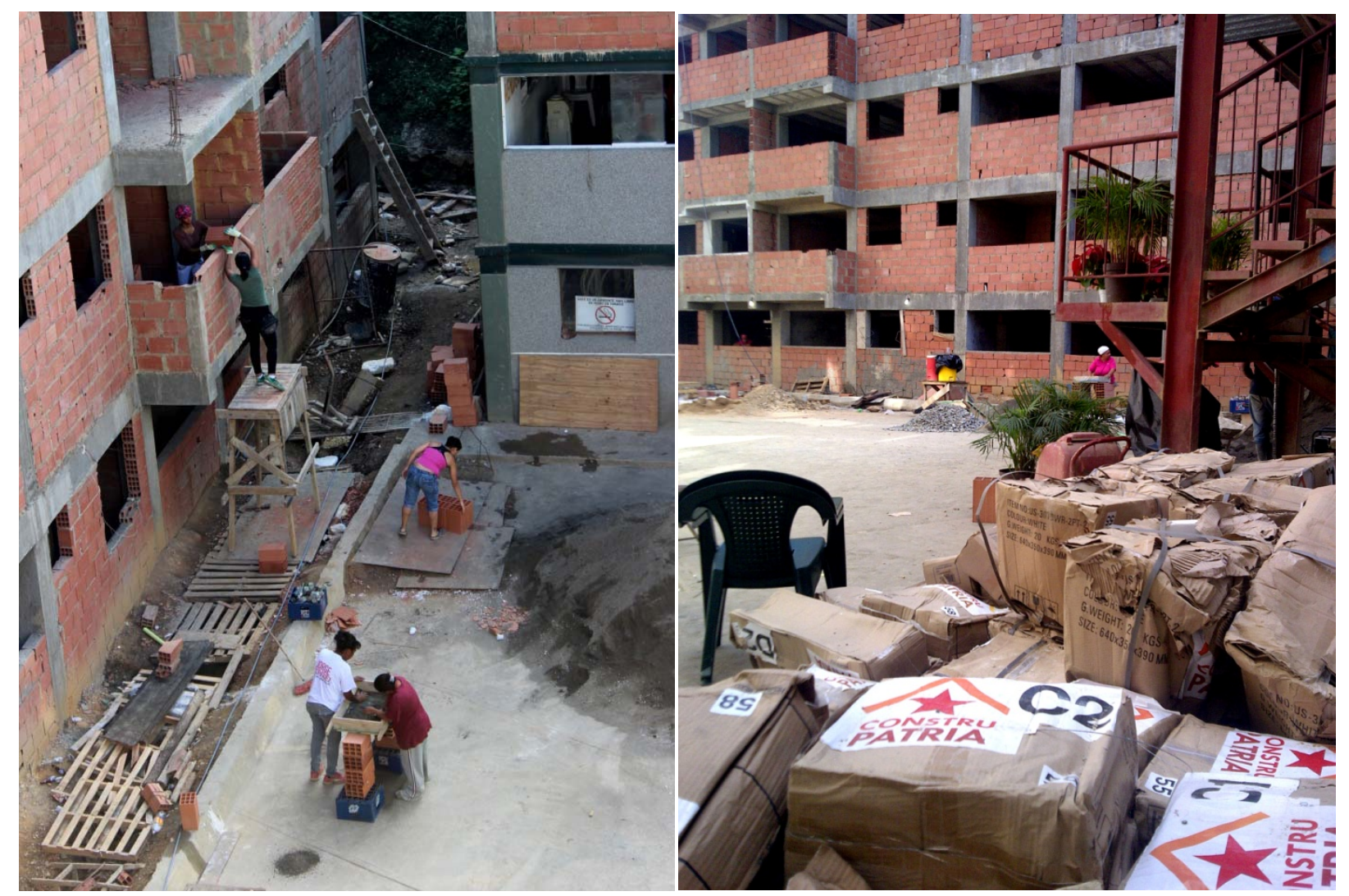

Fig. 124: Trabalho em Mutirão e Material de Construção da Construpatria.

Os Pioneros realizaram levantamento dos equipamentos públicos que haviam na região, e perceberam que havia déficit de creche. Por esse motivo foi prevista a instalação de uma creche, dentro do conjunto. Também em Kaika-Shi está localizada a sala técnica do programa de reabilitação de favelas, que atende toda La Vega.

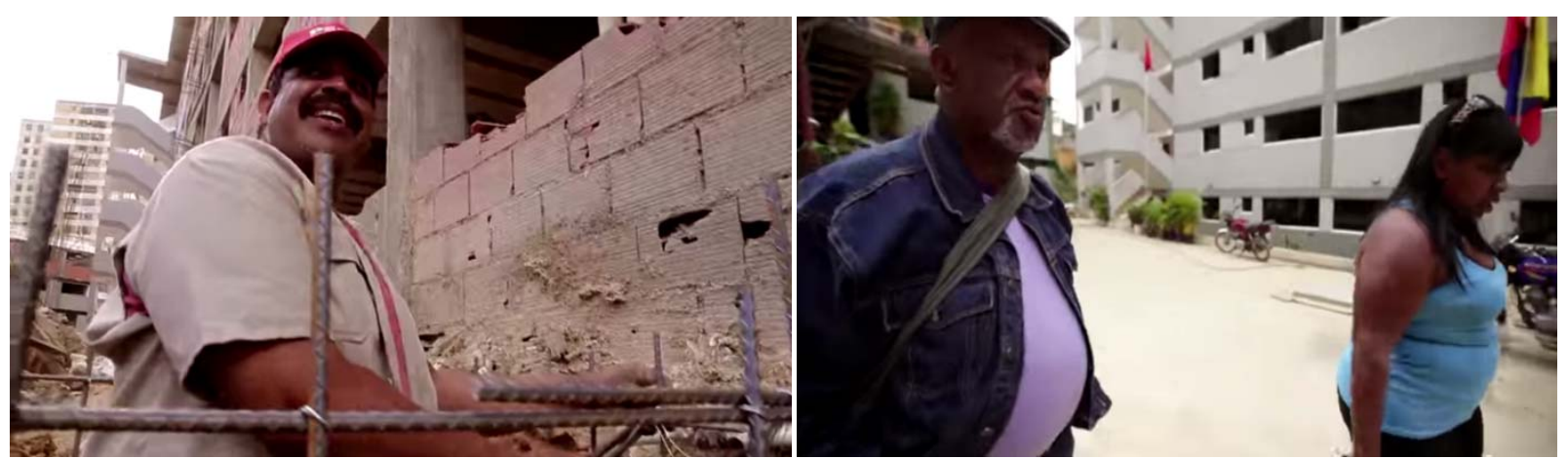

Fig. 125 e 126: Simón Bolívar, o mestre de obras; Edgar Pérez (El Gordo) e Mariela Machado. Fonte: Documentário Campamento de Pioneros Kaika-Shi (Parroquia La Vega).

Juan Albañil, que no Brasil conhecemos como Pedro Pedreiro, em Kaika-Shi é Simón Bolívar.

Não o libertador, mas o mestre de obras. Em suas palavras, 
"Tengo 20 años haciendo edifícios, centros comerciales, y una cantidad de cosas, para empresa privada, y no he podido tener un rancho, pues. (...) El cariño con que van a querer, con que van a morar en su casa va ser grandíssimo, porque hicieron con sus propias manos. Y sobretodo yo. Que contruí tanto. Yo más que nadie tengo que creer en eso. Porque tanto que construí, y no tengo nada, y me deran esa chance, de aqui me sacan muerto. Increíble".

Nossa primeira noite no Campamento de Pioneros Kaika-Shi coincidiu com a concretagem da última laje, às 22hrs. Os trabalhadores mutirantes desciam um a um. O último a descer foi Simón Bolívar, o mestre de obras. Ele era o maior de todos, e abraçava um por um, levantava, girava, e chorava muito. Ao fim, todos gritaram: "eso sí es victoria, victoria popular!". Ao fundo, os prédios de classe média, inicialmente construídos pelo Estado para abrigar desabrigados pela chuva, de onde partiram tiros no começo da obra de Kaika-Shi; as ruínas da primeira e maior fábrica de cimentos da Venezuela, uma ruga na paisagem que faz emergir a história da construção violenta da cidade; e a favela de La Vega, muito conhecida pelas fotografias em preto e branco do livro apocalíptico de Mike Davis, através das quais não se imaginariam as possibilidades de um espaço de esperança. 
Reflexões Finais 
É certo que temos na Venezuela um programa habitacional fora da curva no contexto latinoamericano. Para quem atua no Brasil com o Minha Casa Minha Vida, o choque de realidades é evidente. No Brasil assisitimos ao aprofundamento de uma lógica na qual a luta por habitação encontra-se diante da ausência de uma política fundiária, burocratização progressiva dos programas habitacionais, limitação da intervenção estatal apenas ao financiamento, e aumento do poder do capital imobiliário e da construção civil. O contraste é enorme, a despeito de discursos que insistem em classificar o programa venezuelano como "cópia detalhada" do brasileiro. Na Venezuela o Estado, por meio do Gran Misión Vivienda Venezuela, intervém na cadeia produtiva da construção habitacional, criando condições para que a terra ${ }^{59}$ e os materiais sejam viabilizados, e que outros agentes executores (como a população organizada) participem da construção das habitações.

No entanto, nos perguntamos em que medida o Gran Misión Vivienda Venezuela acaba por se configurar como o mais novo truque do Estado Mágico, um novo grande projeto amparado pelos recursos petroleiros? Em que medida o programa Gran Misión Vivienda Venezuela, em que pese suas qualidades intrínsecas, acaba por cair na vala comum do clientelismo - mais um presente tirado da cartola mágica do insustentável Estado paternalista petroleiro ${ }^{60}$ ?

De qualquer forma, entre tantos falsos problemas que marcaram a história da política habitacional na Venezuela, o Gran Misión Vivienda Venezuela apresenta uma ação incisiva sobre questão habitacional, o que se evidencia na intervenção em toda a cadeia produtiva.

O exemplo dos Campamentos de Pioneros merece destaque. Nos Pioneros, a consciência de classe se vincula certamente à adjetivação "chavista", mas tão forte quanto isso é seu reconhecimento como trabalhadores construtores da cidade, não mais organizados sob o controle do capital, agora autoorganizados. Este é o motivo pelo qual, em reuniões internas se ouviam livres e constantes as críticas ao próprio governo: burguês, bucrocrático e tecnocrático. Mas o tamanho relativo dos Pioneros dentro do universo da produção habitacional pública é muito pequeno, o que nos faz lembrar da ínfima participação da autogestão em obras habitacionais no Brasil e das tantas dificuldades da autogestão de base.

Outra reflexão que a história da questão urbana na Venezuela nos traz se refere aos limites e possibilidades do movimento social urbano enquanto agente de transformação radical da sociedade. Qual é, afinal, o potencial revolucionário dos movimentos sociais urbanos, que, para David Harvey, "em geral, são subestimados como meras tentativas reformistas de lidar com questões específicas (e não sistêmicas), que então terminam por ser considerados nem como movimentos verdadeiramente revolucionários nem de classe". No caso da Venezuela é difícil fugir dessa questão. Pois estamos falando

\footnotetext{
${ }^{59}$ Ainda que tenha viabilizado terrenos em regiões bem localizadas das cidades, ainda não podemos qualificar como uma Reforma Urbana. Ao menos não da forma como foi realizada em Cuba. O programa habitacional venezuelano se baseia mais no investimento pesado da renda petroleira e menos na intervenção radical na propriedade - agora em comparação à Cuba e não ao Brasil. Mas ainda que Cuba e Venezuela apresentem alinhamento político, a distância histórica das ações urbanas citadas impõem cuidados à comparação.

60 "Acabou a Gran Misión Vivienda Petrolera", dizia uma liderança do Movimiento de Pobladoras y Pobladores no final de 2014 quando se iniciva a queda abrupta dos preços internacionais do petróleo.
} 
de um país que, ao ter seu campo esvaziado, apresenta um movimento social rural relativamente pequeno e, ao manter o baixo nível de industrialização não desenvolveu um movimento sindical forte como no Brasil ou na Argentina.

Os Pobladores, por sua parte, se caracterizam como sujeitos fundamentais em uma luta anti-sistêmica: "Apostamos por la construcción de un programa de luchas que reconoce en los pobladores, los pobres y excluidos de la ciudad, un sujeto fundamental en el combate contra el capitalismo en el contexto urbano y por lo tanto, un sujeto fundamental del proceso revolucionário". Como lembra o líder comunitário Edgar Pérez, de La Vega, fazendo referência à luta das favelas, Hugo Chávez "es hijo de este proceso". A revolução bolivariana é certamente uma revolução que emerge das contradições econômicas. Mas as contradições se desenvolvem no território material objetivo da sociedade - no caso da Venezuela, as grandes cidades com suas enormes favelas rodeadas de um campo esvaziado. A real importância dos fenômenos políticos ligados à questão urbana demandaria uma análise aprofundada à luz dos conhecidos limites e contradições da revolução bolivariana - que hoje chegam no limite do insustentável.

Finalmente, colocamos ainda mais uma reflexão advinda de nosso breve olhar sobre a questão urbana na Venezuela. Em uma sociedade rentista, qual o papel da renda da terra? Qual é e como funciona a articulação entre a renda da terra petroleira e a renda da terra urbana? Qual o impacto dessa articulação nas cidades? São questões que também demandam um estudo específico.

Como não poderia deixar de ser, a realização de uma dissertação que fornece um panorama geral sobre um tema amplo como a questão urbana e habitacional na Venezuela contemporânea nos traz mais perguntas do que conclusões. Esperamos que a história que investigamos e as breves reflexões, ainda que não conclusivas, contribuam no desencadeamento de idéias provocativas necessárias aos debates sobre as cidades da periferia do capitalismo, sobretudo em nossa América Latina. 


\section{Bibliografia}


ADDOR, Felipe. Teoria Democrática e Poder Popular na América Latina: Contribuições a partir das experiências de Cotacachi/Equador e Torres/Venezuela. Tese de Doutorado. Programa de PósGraduação em Planejamento Urbano e Regional. Universidade Federal do Rio de Janeiro. 2013

ALFONZO, Juan Pablo. Hundiéndonos en el Excremento de Diablo. Caracas: Banco Central de Venezuela, 2011.

ALMANDOZ, Arturo. La ciudad en el imaginario venezolano III. De 1958 a la metrópoli parroquiana. Caracas: Fundación para la Cultura Urbana, 2009.

ALMONDOZ, Arturo. Urbanismo europeo en Caracas (1870-1940), 2da. Edición, Caracas, Fundación para la Cultura Urbana, 2006.

AMAYA, Carlos. Desarrollo histórico del sistema urbano venezolano: modelos de organización. Revista Geográfica Venezolana, Universidad Los Andes, vol. 40, Mérida, 1999.

ANGOTTI, Tom. Planeta favela. Pós. Revista do Programa de Pós-Graduação em Arquitetura e Urbanismo da FAUUSP, [S.I.], n. 25, p. 357-366, jun. 2009.

ANTILLANO, A. La lucha por el reconocimiento y la inclusión en los barrios populares: la experiencia de los Comités de Tierras Urbanas, Revista Venezolana de Economía y Ciencias Sociales, n. ${ }^{\circ}$ 3, pp. 205218., Caracas, 2005.

ANTILLANO, Andrés. Comités de Tierra Urbana. In RIBES, Maria Ramírez (compiladora). Lo mío, lo tuyo, lo nuestro... visiones sobre la propiedad. Club de Roma. Capítulo Venezoelano, Caracas, 2006.

ARANTES, Pedro Fiori. O ajuste urbano: as políticas do Banco Mundial e do BID para as cidades. Pós. Revista do Programa de Pós-Graduação em Arquitetura e Urbanismo da FAUUSP, [S.I.], n. 20, p. 60-75, dez. 2006.

ARCONADA, S. Mesas Técnicas de Agua y Consejos Comunitarios de Agua. Revista Venezolana de Economía y Ciencias Sociales, vol. 12, núm. 2, mayo-agosto,pp. 127-132, Universidad Central de Venezuela, Caracas, 2006.

AZEVEDO, Sergio. Vinte e dois anos de política de habitação popular (1964-86): Criação, trajetória e extinção do BNH. Revista de Administração Pública, 22 (4), 107-119, out./dez., 1988.

BANCO NACIONAL DE HABITAÇÃO (BNH). Projetos de Lotes Urbanizados. Rio de Janeiro: Secretaria de Divulgação do BNH, 1978.

BARAVELLI, José. O cooperativismo uruguaio na habitação social de São Paulo. Das cooperativas FUCVAM à Associação de Moradia Unidos de Vila Nova Cachoeirinha. São Paulo: dissertação (mestrado), Universidade de São Paulo, Faculdade de Arquitetura e Urbanismo, 2008. 
BARROS, Pedro. Governo Chávez e Desenvolvimento: a Política Econômica em Processo. Mestrado. Pontifícia Universidade Católica de São Paulo. São Paulo, 2007.

BetANCOURT, Rómulo. Venezuela, Política y Petróleo. Caracas: edición conjunta Academia de Ciencias Políticas y Sociales, Universidad Católica Andrés Bello, Fundación Rómulo Betancourt, 2007.

BOLAFFI, Gabriel. Habitação e Urbanismo. O Problema e o falso problema. Cadernos (Universidade de São Paulo, Centro de Estudos Rurais e Urbanos),v. 9, São Paulo, 1976.

BOLÍVAR, Teolinda et. al. Problemas de la Densificación de los barrios caraqueños y sus consecuencias. Sector de Estudios Urbanos, Facultad de Arquitectura y Urbanismo, UCV, mimeo, Caracas, 1991.

BOLÍVAR, Teolinda e BALDÓ, Josefina (ORG.). La cuestión de los barrios. Caracas: Fundación Polar, Universidad Central de Venezuela, Monte Avila Editores, 1996.

BOLÍVAR, Teolinda. Urbanizadores y Constructores para ser Citadinos. Revista Urbana 16-17, Instituto de Urbanismo, FAU, UCV, Caracas, 1995.

BOLÍVAR, Teolinda. Reahabilitación y Reconocimiento de los barrios urbanos. Su necesidad y riesgos. IN: BOLÍVAR, Teolinda e BALDÓ, Josefina (ORG.). La cuestión de los barrios. Caracas: Fundación Polar, Universidad Central de Venezuela, Monte Avila Editores, 1996. p 93-101.

BRUCE, Mariana. A "democracia participativa y protagónica", o povo e o líder: a experiência dos Consejos Comunales na Parroquia 23 de Enero (Caracas/Venezuela). Dissertação (mestrado). Universidade Federal Fluminense, Instituto de Ciências Humanas e Filosofia, 2011.

BRUCE, Mariana. Movimentos Sociais e Bolivarianismo. Tempo Presente, edição dezembro, 2013.

BRUMLIK, Ana. El dilema de la excelencia versus la improvisacion. IN: BOLÍIAR, Teolinda e BALDÓ, Josefina (ORG.). La cuestión de los barrios. Caracas: Fundación Polar, Universidad Central de Venezuela, Monte Avila Editores, 1996. p 83-86.

CABALLERO, M. La Descentralización Venezolana: la Gran Revolución del Fin de Milenio. em MASCAREÑO, C. (coord.). Descentralización Gobierno y Democracia. Universidad Central de Venezuela, Centro de Estudios de Desarrollo, 1998.

CARIOLA, C. e LACABANA, M. (2005b), Los bordes de la esperanza: nuevas formas de participación popular y gobiernos locales en la periferia de Caracas. Cuadernos del CENDES, vol. 22, n. 59, may-ago, pp. 111-133, Centro de Estudios de Desarrollo, Universidad Central de Venezuela, Caracas, 2005b.

CARIOLA, C. e M. Lacabana. La metrópoli fragmentada: Caracas entre la pobreza y la globalización. Revista EURE, Maio, Santiago, 2001.

CARIOLA, Cecília. Crisis, Pobreza y Segregación Urbana: El Deterioro de las condiciones de vida en los barrios populares. IN: BOLÍVAR, Teolinda e BALDÓ, Josefina (ORG.). La cuestión de los barrios. Caracas: Fundación Polar, Universidad Central de Venezuela, Monte Avila Editores, 1996. p 93-101. 
CARIOLA, Cecília e LACABANA, Miguel. Entre la Ciudad Global y la Periferia en Transición. CaracasValles del Tuy Medio. Caracas: Ediciones Ministerio del Poder Popular para Ciencia y Tecnologia, 2006.

CALVO, Azier e VILLALOBOS, Eugenia. 80 años de vivienda en Venezuela 1928-2008. Caracas: Ediciones de la Facultad de Arquitectura e Urbanismo, Universidad Central de Venezuela, 2008.

CALZADILLA, Sandra, et. al. La organización comunitaria. Análisis de un proceso exitoso: Comunidad Las Casitas de La Vega. Revista Venezolana de Análisis de Coyuntura, v. VI, numero 1, enero-julio, pp 189-212, Universidad Central de Venezuela, 2000.

CAMACHO, Oscar et. al. Oportunidades y restricciones para la intervención del sector financiero privado en los programas de rehabilitación de barrios previstos en la Ley de Política Habitacional. IN: BOLÍVAR, Teolinda e BALDÓ, Josefina (ORG.). La cuestión de los barrios. Caracas: Fundación Polar, Universidad Central de Venezuela, Monte Avila Editores, 1996. p 161-170.

CÁRDENAS, Afonso. Diseño en Avance. Políticas, arquitectura y urbanismo en Venezuela en la década de los sesenta. IN: CALVO, Azier e VILLALOBOS, Eugenia. 80 años de vivienda en Venezuela 19282008. Caracas: Ediciones de la Facultad de Arquitectura e Urbanismo, Universidad Central de Venezuela, 2008, pp 31-33.

CARMO, C.; DASSO JR., A.; HITNER, V. Federalismo, Democratização e Construção Institucional no Governo Hugo Chávez. 2011. mimeo.

CILENTO, Alfredo. El Papel del Estado y el Financiamiento. IN: BOLÍVAR, Teolinda e BALDÓ, Josefina (ORG.). La cuestión de los barrios. Caracas: Fundación Polar, Universidad Central de Venezuela, Monte Avila Editores, 1996. p 151-159.

CILENTO, Alfredo. Cambio de Paradigma del Habitat. Universidad Central de Venezuela (UCV), Consejo de Desarrollo Cinentífico y Humanístico; Instituto de Desarrollo Experimental de la Construcción (IDEC). Caracas, 1999.

CILENTO, Alfredo. La mercancía Vivienda en Venezuela. Caracas, mimeo, IDEC-FAU-UCV, 1980.

COMITÉS DE TIERRA URBANA, MOVIMIENTO DE POBLADORES. Socialismo y Tenencia de la Tierra Urbana Popular. em López Maya, M. (Editora). Ideas para Debatir el Socialismo del Siglo XXI. Volumen II. Editorial Alfa, Caracas, 2009.

CONTRERAS NATERA, M. Cambios y Discontinuidades del Proceso de Descentralización en el Gobierno de Chávez. Revista Venezolana de Economía y Ciencias Sociales, v. 9, n. 3, p. 255-272, sept.-dec,, Universidad Central de Venezuela, Caracas, 2003.

CORONIL, Fernando. El Estado Mágico: Naturaleza, Dinero y Modernidad en Venezuela. Caracas: Editorial Alfa, 2013.

DAVIS, Mike. Planeta Favela. São Paulo: Boitempo Editorial, 2006.

DENIS, R. Los Fabricantes de la Rebelión: movimiento popular, chavismo y sociedad en los años noventa. Caracas: Editorial Primera Línea, 2001. 
FURTADO, Celso. Ensaios sobre a Venezuela: subdesenvolvimento com abundância de divisas. Rio de Janeiro: Contraponto, Centro Internacional Celso Furtado, 2008.

FREY, Jean; Manzanilla, Hugo; Palacios, Luis. Introducción a la teoría de la renta. Caracas: Ediciones Siap, Instituto de Arquitectura e Urbanismo, Universidad Central de Venezuela, 1980.

GARCÍA-GUADILLA, M., Organizaciones Sociales y Conflictos sociopolíticos en una sociedad polarizada: las dos caras de la democracia participativa en Venezuela, America Latina Hoy, n. ${ }^{\circ}$ 42, Salamanca, Ediciones Universidad de Salamanca, 2006.

GARCÍA-GUADILLA, M. Ciudadanía, Inclusión y Autonomía en las Organizaciones Sociales Bolivarianas: Los Comités de Tierra Urbana. XXVI Conferencia Internacional de la Latin American Studies Association (LASA). San Juan de Puerto Rico 15-18 de marzo, 2006.

GONZÁLES, Silverio. La ciudad venezolana. Una interpretación de su espacio y su sentido en la convivencia nacional. Caracas: Fundación para la Cultura Urbana, 2005.

HELLINGER, D. Como entiende el Pueblo la democracia protagónica? Resultados de una Encuesta. Revista Venezolana de Economía y Ciencias Sociales. v. 14, n.1, abr., Caracas, 2008.

HENRIQUE, Hernández. Consideraciones sobre el proyecto de 'ley del régimen prestacional de vivienda y habitat'. in GENATIOS, Carlos. Venezuela en Perspectiva. Question Fondo Editorial, Caracas, 2004.

HONNET, Axel. Luta por Reconhecimento: a Gramática Moral dos Conlitos Sociais. Trad. de Luiz Repa. Editora 34, São Paulo, 2003.

INFANTE, Ricardo e SÁNCHEZ, Magaly. Reproducción de la Estructura Urbana de Caracas: Crisis Urbana y Crecimiento Acelerado de Zonas Segregadas. Revista Urbana 1, Instituto de Urbanismo, FAU, UCV, Caracas, 1979.

LAZARINI, Kaya. Luta por moradia e autogestão em Buenos Aires: da crise à construção popular do hábitat. Dissertação (mestrado). São Paulo: Universidade de São Paulo, Faculdade de Arquitetura e Urbanismo, 2014.

LE TROUDI, H., MONEDERO, J. C. Empresas de Producción Social: Instrumentos para el Socialismo del Siglo XXI. Centro Internacional Miranda, Caracas, 2006.

LÓPEZ MAYA, M. Del Viernes Negro al Referendo Revocatorio. Alfadil Ediciones, Caracas, 2005.

LÓPEZ MAYA, M. Democracia Participativa en Venezuela (1999-2010). Orígenes, Leyes, Percepciones y Desafíos. Temas de Formación Política, n. 50, Fundación Centro Gumilla, Universidad Católica Andrés Bello, Caracas, 2011.

LÓPEZ MAYA, Margarita. Del Viernes Negro al Referendo Revocatorio. Colección hogueras: Venezuela Profunda. Alfadil Ediciones, Caracas, 2005. 
LÓPEZ VILLA, Manuel. Banco Obrero, 1928. IN: CALVO, Azier e VILLALOBOS, Eugenia. 80 años de vivienda en Venezuela 1928-2008. Caracas: Ediciones de la Facultad de Arquitectura e Urbanismo, Universidad Central de Venezuela, 2008, pp 31-33.

LÓPEZ, Manuel. Dictadura y Urbanizacion. La transformación del medio físico en Venezuela durante la década militar (1948-1958) Parte II. Resistencia, 1993.

LOVERA, Alberto. Apuntes sobre la investigación urbana en Venezuela. IN: MARÍN FRECHILLA, Juan e LOVERA, Alberto (COMP.). La Ciudad: de la planificación a la privatización. Caracas: Universidad Central de Venezuela, Consejo de Desarrollo Científico y Humanístico, Fondo Editorial Acta Científica Venezolana, 1994.

LOVERA, Alberto (COMP.). La Ciudad: de la planificación a la privatización. Caracas: Universidad Central de Venezuela, Consejo de Desarrollo Científico y Humanístico, Fondo Editorial Acta Científica Venezolana, 1994. p. 57-108.

Los grandes ausentes: Vivienda y barrios populares en la politica social. IN: BOLÍVAR, Teolinda e BALDÓ, Josefina (ORG.). La cuestión de los barrios. Caracas: Fundación Polar, Universidad Central de Venezuela, Monte Avila Editores, 1996. p 177-187.

Alberto. Del Banco Obrero a la UCV. Los orígenes del Instituto de Desarrollo Experimental de la Construcción (IDEC). Centro de Estudios del Desarrollo (IDEC), Universidad Central de Venezuela (UCV). Caracas, 2004.

MACHADO M., J. Participación Social y Consejos Comunales en Venezuela. Revista Venezolana de Economía y Ciencias Sociales, v. 15, n.1, Universidad Central de Venezuela, Caracas, 2009.

MADERA, Hector. Comités de Tierra Urbana. In Cities for All: Experiences and Proposals for the Right to the City, SUGRANYES, A. y MATHIVET C., HIC, Santiago, 2010.

MAINGON, T. Consejos Comunales, Ciudadanía, Estado e Poder Popular. em G. Castro (org.), Debate por Venezuela, Caracas, Editorial Alfa/Escuela de Sociología-FACES/UCV, pp. 126-145, 2007.

MATO, D., FERMÍN, A. TORRES, E., Interculturalidad y Comunicación Intercultural. Propuesta Teórica y Estudio de Experiencias de Participación Social en la Gestión de Servicios Públicos en una Comunidad Popular de la Ciudad de Caracas. Universidad Central de Venezuela, Consejo de Desarrollo Científico y Humanístico, Caracas, 2011.

MASCAREÑO, C. (coord.). Descentralización Gobierno y Democracia. Universidad Central de Venezuela, Centro de Estudios de Desarrollo, Caracas, 1998.

MAZA, D. Historia de Medio Siglo en Venezuela. in América Latina de medio siglo. México: S. XXI.

MARICATO, Ermínia. Metrópole na Periferia do Capitalismo: Ilegalidade, Desigualdade e Violência. São Paulo: 1995. 
MARÍN FRECHILLA, Juan e LOVERA, Alberto (COMP.). La Ciudad: de la planificación a la privatización. Caracas: Universidad Central de Venezuela, Consejo de Desarrollo Científico y Humanístico, Fondo Editorial Acta Científica Venezolana, 1994.

MARTÍN FRECHILLA, Juan. Vivienda Popular e iniciativa municipal en Caracas, 1908-1958 (o como algunos pioneros no estaban equivocados). IN: BOLÍVAR, Teolinda e BALDÓ, Josefina (ORG.). La cuestión de los barrios. Caracas: Fundación Polar, Universidad Central de Venezuela, Monte Avila Editores, 1996. p 89-201.

MELCHER, Dorothea. La industrialización de Venezuela. Revista Economía, Universidad Los Andes, n. 10, 1995.

MENDES, Flávio. Hugo Chávez em seu Labirinto. O Movimento Bolivariano e a Política na Venezuela. Ed Alameda. São Paulo, 2012.

MEZA, Beatriz. El taller de arquitectura del Banco Obrero (TABO). Políticas, urbanismo y arquitectura en la década de los cincuenta. IN: CALVO, Azier e VILLALOBOS, Eugenia. 80 años de vivienda en Venezuela 1928-2008. Caracas: Ediciones de la Facultad de Arquitectura e Urbanismo, Universidad Central de Venezuela, 2008, pp 61-67.

MOVIMIENTO DE POBLADORAS Y POBLADORES. Manifiesto por la Revolución Urbana. Unidad del Pueblo por la Ciudad Socialista y Revolución Urbana. Caracas, 2010.

NEGRÓN, Marco. Los Orígenes de la Urbanización contemporánea en Venezuela. El crecimiento sin acumulación entre 1920 y 1945. Revista Urbana 4, Instituto de Urbanismo, FAU, UCV, 1982.

NEGRÓN, M. De pobladores a ciudadanos: Una discusión sobre las relaciones entre democratización y procesos de urbanización a partir de la experiencia venezolana. América Latina Hoy Revista de Ciencias Sociales, n. ${ }^{01}$, Salamanca, Universidad de Salamanca, pp. 81-89, 1991.

OESE. Estructura Económica y Poder Político en Venezuela (Contribución a su Estudio en el Periodo 1944-1959). Caracas: mimeo.

OLIVEIRA, Francisco. A economia brasilieira: crítica à razão dualista e O Ornitorrinco. São Paulo: Boitempo Editorial, 2003.

OVALLES, Omar. Explosión social o redes de solidariedad? Un enfoque urbano del problema. Revista Tierra Firme, año VII, v. 7 , enero-marzo, 1989.

PROVEA. 365 dias de GMVV. 2012. Mimeo.

QUINTANA, Leandro. Políticas y soluciones habitacionales en Venezuela en las décadas de los setenta y ochenta. IN: CALVO, Azier e VILLALOBOS, Eugenia. 80 años de vivienda en Venezuela 1928-2008. Caracas: Ediciones de la Facultad de Arquitectura e Urbanismo, Universidad Central de Venezuela, 2008, pp 61-67. 
QUINTERO, Rodolfo. Antropología del Petróleo. Caracas: Banco Central de Venezuela, 2014.

RONCONI, Reginaldo. Produção de Habitações em regime de mutirão com gerenciamento do usuário: o caso do FUNAPS. Dissertação (mestrado), Universidade de São Paulo, Faculdade de Arquitetura e Urbanismo, 1995.

RIETTI, Sara. (comp.) Oscar Varsavscky: Una lectura postergada. Monte Ávila Ditores Latinoamericana, Ministerio del Poder Popular para Ciencia y Tecnologia, Caracas, 2007.

RÍSQUEZ, Elba. La Organización del Sector Empresarial Privado (Primera Parte: Visión Histórica). Revista sobre Relaciones Industriales y Laborales, Universidad Católica Andrés Bello, n. 21, 1987.

ROSAS, Iris. La relación barrio-ciudad: La tecnología como fenómeno cultural. IN:

SALVADORI, M. Luta por Reconhecimento: a Gramática Moral dos Conflitos Sociais. Revista Conjectura, v. 16, n. 1, jan./abr. 2011, Universidade de Caxias do Sul, Caxias do Sul, 2011. Resenha de: HONNET, Axel. Luta por Reconhecimento: a Gramática Moral dos Conlitos Sociais. Trad. de Luiz Repa. São Paulo: Editora 34, 2003.

SANTOS, B. Uma Cartografia Simbólica das Representações Sociais: Prolegómenos a uma Concepção Pós-Moderna do Direito. Revista Crítica de Ciências Sociais, n. 24, mar., Faculdade de Economia de Coimbra e Centro de Estuados Sociais, Coimbra, 1988.

SANTOS, B. Reinventar a Teoria Crítica e Reinventar a Emancipação Social. São Paulo, Boitempo, 2007.

SANTOS, Milton. Sociedade e Espaço Transnacionalizados na Venezuela Atual. in Ensaios sobre a Urbanização Latino-Americana. Ed. Edusp. São Paulo, 2007.

SANTOS, Milton. Ensaios sobre a Urbanização Latino-americana. São Paulo: Editora da Universidade de São Paulo, 2010.

SANNÁ PINTO, Luiz. Petróleo, Gás e Nacionalismo na Venezuela e na Bolívia: uma Análise Histórica. Prolam, USP. São Paulo, 2009.

SATO, Alberto. Cinco Oficinas de Arquitectura: 1948-1958. Dissertação (mestrado). Facultad de Arquitectura y Urbanismo, Universidad Central de Venezuela. 1996.

SATO, Alberto. Architecture and New National Ideal - Venezuela 1948-1958. Mimeo. (Artigo apresentado no Congresso Architecture and the State: 1940s-1970s, Graduate School of Architecture, Planing and Preservation, Columbia University).

SINGER, Paul. Urbanización, dependencia y marginalidad. Imperialismo y Urbanización en América Latina. p 287-312.

SONIA, Barrios. Metropolización y desigualdades socio-territoriales en Venezuela. Fondo de Población de Naciones Unidas, Asociación Venezolana de Estudios de Población, 2008. 
SOLA, Ricardo. La Reurbanización de El Silencio. Caracas: E. Armitano Editor, 1988.

SOUZA, Celina. Federalismo e Descentralização na Constituição de 1988: Processo Descisório, Conflitos e Alianças. Revista de Ciências Sociais, Rio de Janeiro, Vol. 44, no 3, 2001, pp. 513 a 560.

VALLMITJANA, M. et. al. El Ordenamiento Territorial y Urbano: Reasunción de un Poder Perdido. En: R. De la Cruz (coord.) Descentralización-Governabilidad-Democracia. COPRE-PNUD. Caracas: Ed. Nueva Sociedad.

VILLAÇA, Flávio. Espaço Intra-Urbano no Brasil. São Paulo: Edudio Nobel, FAPESP, Lincoln Institute, 1998.

VELÁSQUEZ, Ramón. Venezuela, el Federalismo y la Descentralización. en

VENEZUELA. Constitución de la República Bolivariana de Venezuela con Exposición de Motivos. Segundo Gaceta Oficial n. 5.453 de 24 de marzo de 2000, con enmienda n. 1 de 15 de febrero de 2009. Segundo Gaceta Oficial n. 5.908 extraordinaria de 19 de febrero de 2009. Caracas, Vadell Hermanos Editores, 2009.

VENEZUELA. Ley de los Consejos Comunales (2006), Caracas, Gaceta Oficial n. ${ }^{0} 38.421$.

VENEZUELA. Decreto 1666/02 (1992), Caracas, Gaceta Oficial n. ${ }^{\circ} 37.378$.

VENEZUELA. Ministerio del Poder Popular para Vivienda y Habitat. Memoria y Cuenta 2011.

VENEZUELA. Ministerio del Poder Popular para Vivienda y Habitat. Memoria y Cuenta 2012.

VILLA, R. Venezuela: Mudanças Políticas na Era Chávez. Revista Estudos Avançados, v.9, n. 55, setdec, Instituto de Estudos Avançados, Dossiê América Latina, Universidade de São Paulo, São Paulo, 2005. 